Argonne

\title{
Final Work Plan: Targeted Investigation at York, Nebraska
}

\section{Environmental Science Division}




\begin{abstract}
About Argonne National Laboratory
Argonne is a U.S. Department of Energy laboratory managed by UChicago Argonne, LLC under contract DE-AC02-06CH11357. The Laboratory's main facility is outside Chicago, at 9700 South Cass Avenue, Argonne, Illinois 60439. For information about Argonne and its pioneering science and technology programs, see www.anl.gov.
\end{abstract}

\title{
DOCUMENT AVAILABILITY
}

Online Access: U.S. Department of Energy (DOE) reports produced after 1991 and a growing number of pre-1991 documents are available free via DOE's SciTech Connect (http://www.osti.gov/scitech/)

Reports not in digital format may be purchased by the public from the National Technical Information Service (NTIS):

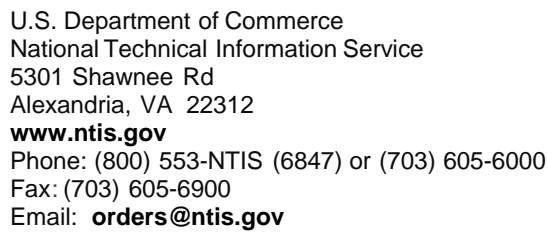

Reports not in digital format are available to DOE and DOE contractors from the Office of Scientific and Technical Information (OSTI):

U.S. Department of Energy

Office of Scientific and Technical Information

P.O. Box 62

Oak Ridge, TN 37831-0062

www.osti.gov

Phone: (865) 576-8401

Fax: (865) 576-5728

Email: reports@osti.gov

\section{Disclaimer}

This report was prepared as an account of work sponsored by an agency of the United States Government. Reference herein to any specific commercial product, process, or service by trade name, trademark, manufacturer, or otherwise, does not necessarily constitute or imply its endorsement, recommendation, or favoring by the United States Government or any agency thereof. The views and opinions of document authors expressed herein do not necessarily state or reflect those of the United States Government or any agency thereof, Argonne National Laboratory, or UChicago Argonne, LLC. 


\section{Final Work Plan: Targeted Investigation at York, Nebraska}

by

Applied Geosciences and Environmental Management Section Environmental Science Division, Argonne National Laboratory

August 2016

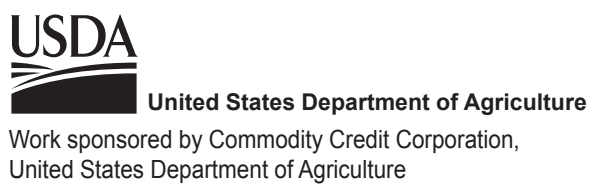




\section{Contents}

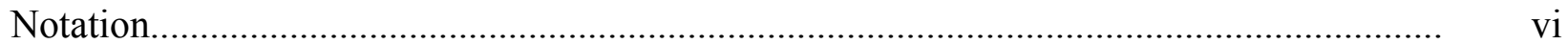

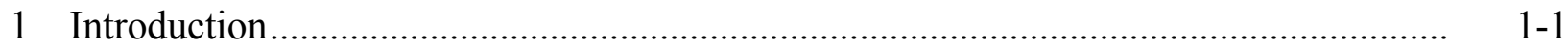

2 Background and Previous Studies ……………………............................................ 2- 2-1

2.1 Overview of the Targeted Investigation Area................................................. 2-1

2.1.1 York Public Water Supply .................................................................. 2-1

2.1.2 Former CCC/USDA Facility and Adjacent Properties............................. 2-3

2.2 Results of Previous CCC/USDA Facility Investigations ..................................... 2-5

2.1.1 Geologic and Hydrogeologic Setting ............................................... 2-6

2.2.2 Carbon Tetrachloride Distribution in Soils ........................................... 2-10

2.2.3 Carbon Tetrachloride Distribution in Groundwater ................................ 2-12

3 Proposed Technical Program ..............................................................................

3.1 Task 1: Verify the Present Distribution of Carbon Tetrachloride in the Shallow and Deeper (Vadose Zone) Soils at and near the Former CCC/USDA Facility.....

3.2 Task 2: Determine the Potential Levels of VOCs Contamination in Soil Vapor at/near the Former CCC/USDA Facility.....

3.3 Task 3: Determine the Current Areal and Vertical Extent of Carbon Tetrachloride Contamination in the Unconfined Aquifer Groundwater Downgradient from the Former CCC/USDA Facility and Establish Permanent Groundwater Monitoring Points

3.4 Task 4: Update the Inventory and Status of Private Wells in the Targeted Investigation Area.

3.5 Task 5: Investigate for Possible Carbon Tetrachloride Contamination of the Deeper (Confined) Aquifer(s).

4.1 Methods for Soil Coring, Sampling, and Analysis

4.2 Methods for Soil Gas Sampling and Analysis

4.3 Methods for Groundwater Sampling and Analysis.

4.3.1 Groundwater Sampling with the Cone Penetrometer ............................... 4-3

4.3.2 Groundwater Sampling with the Drilling Rig ...................................... 4-3

4.3.3 Sample Preservation and Analysis ........................................................ 4-4

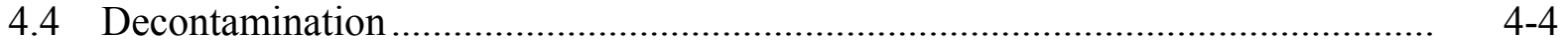

4.5 Methods for Installing Monitoring Wells and Abandoning Boreholes ................. 4.. 4-4

4.6 Methods for Water Level Monitoring ............................................................... 4-5

4.7 Methods for Handling and Disposal of Investigation-Derived Waste................... 4 4-5

4.8 Quality Assurance/Quality Control for Sampling and Analysis.......................... 4-6 4.8.1 Field Quality Assurance/Quality Control for Sampling and Analysis ......... 4-7 
4.8.2 Laboratory Quality Assurance/Quality Control for Sampling and Analysis

4.8.3 Quality Assurance Records ................................................................. 4-11

4.8.4 Analytical Data Reduction, Validation, and Reporting........................... 4-12

4.9 Field Investigation Schedule ...................................................................... 4-14

5 Community Relations Plan ........................................................................... $5-1$

5.1 Site Description.....................................................................................

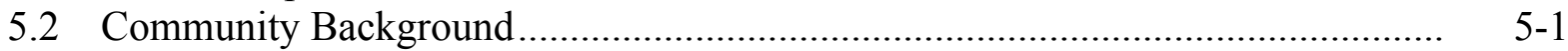

5.2.1 History of Community Involvement .............................................. $5-2$

5.2.2 Key Community Concerns .................................................................. 5-3

5.3 Community Relations Objectives ............................................................... $5-3$

5.4 Timing of Community Relations Activities................................................... $5-4$

5.4.1 Activities before Field Work Begins ................................................. 5-4

5.4.2 Activities during Field Work ................................................................. $5-5$

5.4.3 Activities upon Completion of Field Work Activities ............................. 5 5-6

5.5 Contact List of Key Officials ....................................................................

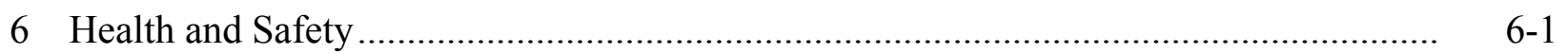

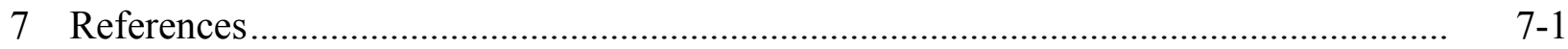

Appendix A: Nebraska Wellhead Protection Area Maps for the York Public Water Supply System …............................................................................. A-1

Supplement 1: Historical Property Ownership Records .............................................. on CD

\section{Tables}

2.1 Construction and status of the York municipal supply wells .............................. 2-15

2.2 Organic analysis results for shallow soil samples, 1994-1995 ........................... 2-17

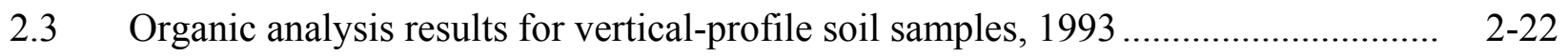

2.4 Organic analysis results for groundwater samples, 1993 ................................. 2-26

2.5 Analytical results for VOCs in groundwater samples collected from private wells, 2013-2015

6.1 Emergency information for the investigation at York, Nebraska 


\section{Figures}

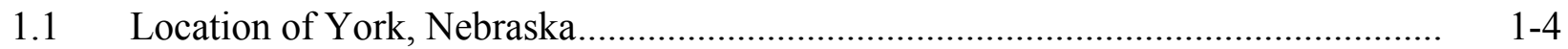

1.2 Locations of contaminated public water supply wells PWS 37-1, PWS 48-1, and PWS 81-1

2.1 Locations of the former CCC/USDA facility and selected current community facilities, with approximate locations of irrigation wells in the targeted investigation area

2.2 Locations and status of the York public water supply wells

2.3 Approximate locations of parcels leased by the CCC/USDA for grain storage in 1950-1967 and 1950-1974

2.4 The former CCC/USDA grain storage facility in 1956

2.5 The former CCC/USDA grain storage facility in 1962

2.6 The former CCC/USDA grain storage facility in 1968

2.7 The former CCC/USDA grain storage facility in 1974

2.8 The former CCC/USDA grain storage facility in 1977

2.9 The former CCC/USDA grain storage facility in 1981

2.10 The former CCC/USDA grain storage facility in 1988

2.11 The former CCC/USDA grain storage facility in 1993 .......

2.12 The former CCC/USDA grain storage facility in 1999

2.13 The former CCC/USDA grain storage facility in 2012 ...

2.14 Approximate boundaries of properties near the former CCC/USDA facility

2.15 Approximate locations of the wells and investigative borings that provided lithologic information used to develop local hydrostratigraphic interpretations in the 1993-1995 investigations, with locations of interpretive cross sections $\mathrm{A}-\mathrm{A}^{\prime}, \mathrm{B}-\mathrm{B}^{\prime}$, and $\mathrm{C}-\mathrm{C}^{\prime}$.....

2.16 Northwest-to-southeast geologic cross section A-A'

2.17 Southwest-to-northeast geologic cross section B-B' ........................................ $2-54$

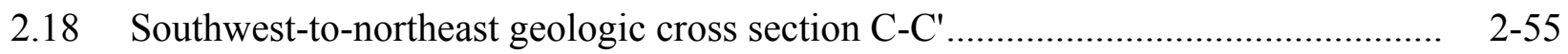


2.19 Carbon tetrachloride concentrations in near-surface soil samples collected in September 1994 at the former CCC/USDA facility, as determined by screening analysis.

2.20 Carbon tetrachloride concentrations in near-surface soil samples collected in October 1994 and March 1995 at the former CCC/USDA facility, as determined by CLP analysis

2.21 Carbon tetrachloride and chloroform concentrations in vegetation samples collected in July 1993 at the former CCC/USDA facility and the adjacent Gun Club property, as determined by headspace analysis.

2.22 Approximate locations of vertical-profile soil samples collected in 1993 for VOCs analysis

2.23 Vertical distributions of carbon tetrachloride and chloroform in soils collected in 1993 at investigative borings SB62, SB37, and SB01

2.24 Approximate locations of the groundwater samples collected from investigative borings in 1993 for VOCs analyses.

2.25 Approximate locations of groundwater samples collected from private, irrigation, and municipal supply wells in 1993 for VOCs analyses

2.26 Lateral distribution of carbon tetrachloride in groundwater samples collected in 1993

2.27 Carbon tetrachloride concentrations in groundwater samples collected from selected private and municipal supply wells in 2013-2015

3.1 Recommended locations for deep soil sampling for VOCs analyses

3.2 Recommended locations for groundwater sampling for VOCs analyses

6.1 Route from the investigation site to York General Hospital. 


\section{Notation}

AGEM Applied Geosciences and Environmental Management

AMSL above mean sea level

BGL below ground level

${ }^{\circ} \mathrm{C} \quad$ degree(s) Celsius

CCC Commodity Credit Corporation

CD compact disc

CERCLA Comprehensive Environmental Response, Compensation, and Liability Act

CERCLIS CERCLA Information System

CLP Contract Laboratory Program

$\mathrm{cm} \quad$ centimeter(s)

CPT cone penetrometer

1,1-DCE 1,1-dichloroethylene

EPA U.S. Environmental Protection Agency

$\mathrm{ft} \quad$ foot (feet)

gal gallon(s)

GC-ECD gas chromatography-electron capture detection

GC-MS gas chromatography-mass spectrometry

gpm gallon(s) per minute

$\mathrm{hr} \quad$ hour(s)

ID inner diameter

IDW investigation-derived waste

in. $\quad$ inch(es)

L liter(s)

MCL maximum contaminant level

$\mu \mathrm{g} / \mathrm{kg} \quad$ microgram(s) per kilogram

$\mu \mathrm{g} / \mathrm{L} \quad$ microgram(s) per liter

mi mile(s)

$\min \quad$ minute(s)

NDEC Nebraska Department of Environmental Control

NDEQ Nebraska Department of Environmental Quality

NDHHS Nebraska Department of Health and Human Services

NDOH Nebraska Department of Health

NPL National Priorities List

PCE tetrachloroethylene 
ppb part(s) per billion

PRT Post Run Tubing

PVC polyvinyl chloride

PWS public water supply

QA/QC quality assurance/quality control

TCE trichloroethylene

TCLP toxicity characteristic leaching procedure

TRPH total recoverable petroleum hydrocarbon

USDA U.S. Department of Agriculture

USGS U.S. Geological Survey

VCP Voluntary Cleanup Program

VOC volatile organic compound

WhAEM Wellhead Analytic Element Model

WHP Wellhead Protection (Program)

WHPA wellhead protection area

yr year(s) 


\section{Final Work Plan: Targeted Investigation at York, Nebraska}

\section{Introduction}

From 1950 until 1974, the Commodity Credit Corporation (CCC) of the U.S. Department of Agriculture (USDA) operated a grain storage facility on leased property in the northern portion of York, Nebraska (Figure 1.1). During this time, commercial grain fumigants containing carbon tetrachloride were commonly used by the CCC/USDA and the private grain storage industry to preserve grain in their facilities.

In 1990, routine sampling by the Nebraska Department of Health (NDOH) identified contamination by volatile organic compounds (VOCs) including trichloroethylene (TCE), tetrachloroethylene (PCE), 1,1-dichloroethylene (1,1-DCE), and carbon tetrachloride in several York public water supply (PWS) wells. Except for TCE, however, all VOCs concentrations were below the maximum contaminant levels (MCLs) for the respective compounds.

Levels of TCE significantly above the MCL $(5.0 \mu \mathrm{g} / \mathrm{L})$ for this compound were detected in well PWS 81-1. After unsuccessful attempts to purge PWS 81-1 of the contaminant, the well was shut down in early 1990. Low concentrations of carbon tetrachloride (less than the MCL of $5.0 \mu \mathrm{g} / \mathrm{L}$ for this compound) were also detected at PWS 81-1 at this time, as well as in two additional municipal wells (PWS 37-1 and PWS 48-1; Figure 1.2).

As a result of the contamination found in well PWS 81-1, the U.S. Environmental Protection Agency (EPA) placed the York contamination site in CERCLIS in May 1990. In subsequent studies conducted by the NDOH and the Nebraska Department of Environmental Quality (NDEQ; formerly the Nebraska Department of Environmental Control, NDEC), groundwater contamination by multiple VOCs, including carbon tetrachloride, was also identified in numerous private wells in the northern portion of the town. This prompted the EPA, in April 1991, to provide bottled water to seven households with contaminated private wells and no connection to the York municipal water system (NDEC 1990; PES 1991). In September 1991, the NDEC concluded that the MCLs for TCE, PCE, 1,1-DCE, and carbon tetrachloride had been exceeded in both public and private wells. The agency indicated that multiple potential source areas, including the former CCC/USDA grain storage facility, might have contributed to the contamination, although no specific sources were conclusively identified (NDEC 1991). 
On the basis of these findings, the CCC/USDA initiated an investigation of carbon tetrachloride contamination potentially associated with its former York grain storage facility (Argonne 1993). The studies, conducted in 1993-1995, focused on the former CCC/USDA facility and did not attempt to address potential contaminant contributions from other source areas. The results identified carbon tetrachloride contamination in subsurface soils at and immediately to the east of the former CCC/USDA facility (on an adjacent property), as well as in groundwater in the uppermost aquifer unit beneath and to the southeast (downgradient) of the former facility. The concentrations exceeded the current NDEQ regulatory targets for carbon tetrachloride (39 $\mu \mathrm{g} / \mathrm{kg}$ in soils; $5.0 \mu \mathrm{g} / \mathrm{L}$ in groundwater). Low levels of carbon tetrachloride were also detected in association with other VOCs, including TCE and PCE, in an apparent second, detached lobe of groundwater contamination south of the former CCC/USDA facility that could not be linked to the former CCC/USDA grain storage operations (Argonne 1994, 1995a).

These findings were interpreted as evidence of one or more additional contaminant source area(s) south of the former facility. The results of the site characterization studies became the basis for an evaluation of potential strategies for restoration of the contaminated soils and groundwater associated with the former CCC/USDA facility. The strategies considered were groundwater extraction, treatment by air stripping or spray irrigation, and infiltration/reinjection or discharge of the resulting effluent (Argonne 1995b).

Upon completion of the 1993-1995 studies, no further investigation activities pertaining to the former CCC/USDA facility were requested by the EPA or the NDEQ until 2014. Further investigations by the EPA and the NDEQ between 1995 and 2014, however, identified two distinct areas of VOCs contamination (primarily TCE and PCE; unrelated to the former CCC/USDA facility) in groundwater in the more southern portions of York (EPA 1996; NDEQ 2010, 2011; SETI 2011; Tetra Tech 2012a,b,c). These areas, now designated the PCE Southeast Contamination site and the PCE/TCE Northeast Contamination site, were placed on the EPA National Priorities List (NLP) in May 2014 (EPA 2013a,b, 2014a,b). Information presently available to the CCC/USDA indicates that the PCE/TCE Northeast Contamination site incorporates the southern lobe of low-level carbon tetrachloride and other VOCs contaminants identified in groundwater during the 1993-1995 CCC/USDA investigations.

In conjunction with the groundwater contamination issues elsewhere at York, the EPA and NDEQ have requested that the CCC/USDA expand its earlier studies of carbon tetrachloride 
contamination associated with its former grain storage operations. Specifically, the CCC/USDA has been asked to (1) verify the previous investigation results for carbon tetrachloride in both soil and groundwater, (2) update these findings to determine the present areal and vertical extent and levels of carbon tetrachloride in soil and groundwater, and (3) identify any risks that the contamination might pose to currently active private or public wells or to public health via other pathways, including potential carbon tetrachloride vapor intrusion.

To address this request, the CCC/USDA has agreed to conduct a targeted investigation at the York site, in accordance with the Intergovernmental Agreement between the NDEQ and the Farm Service Agency of the USDA. The targeted investigation will be performed on behalf of the CCC/USDA by the Environmental Science Division of Argonne National Laboratory, which is operated by UChicago Argonne, LLC, for the U.S. Department of Energy.

The targeted investigation at York will be implemented in phases, so that data collected and interpretations developed at each stage of the program can be evaluated to guide subsequent phases most effectively. Section 2 of this Work Plan presents a brief overview of the York site, its geologic and hydrologic setting, and the previous CCC/USDA investigations. Section 3, outlines the proposed technical program for the targeted investigation, and Section 4 describes the investigative methods to be employed. A community relations plan is in Section 5, and Section 6 includes health and safety information. In addition to this site-specific Work Plan, the Master Work Plan (Argonne 2002) developed by Argonne for CCC/USDA investigations in Nebraska should be consulted for complete details of the methods and procedures to be used at York. 


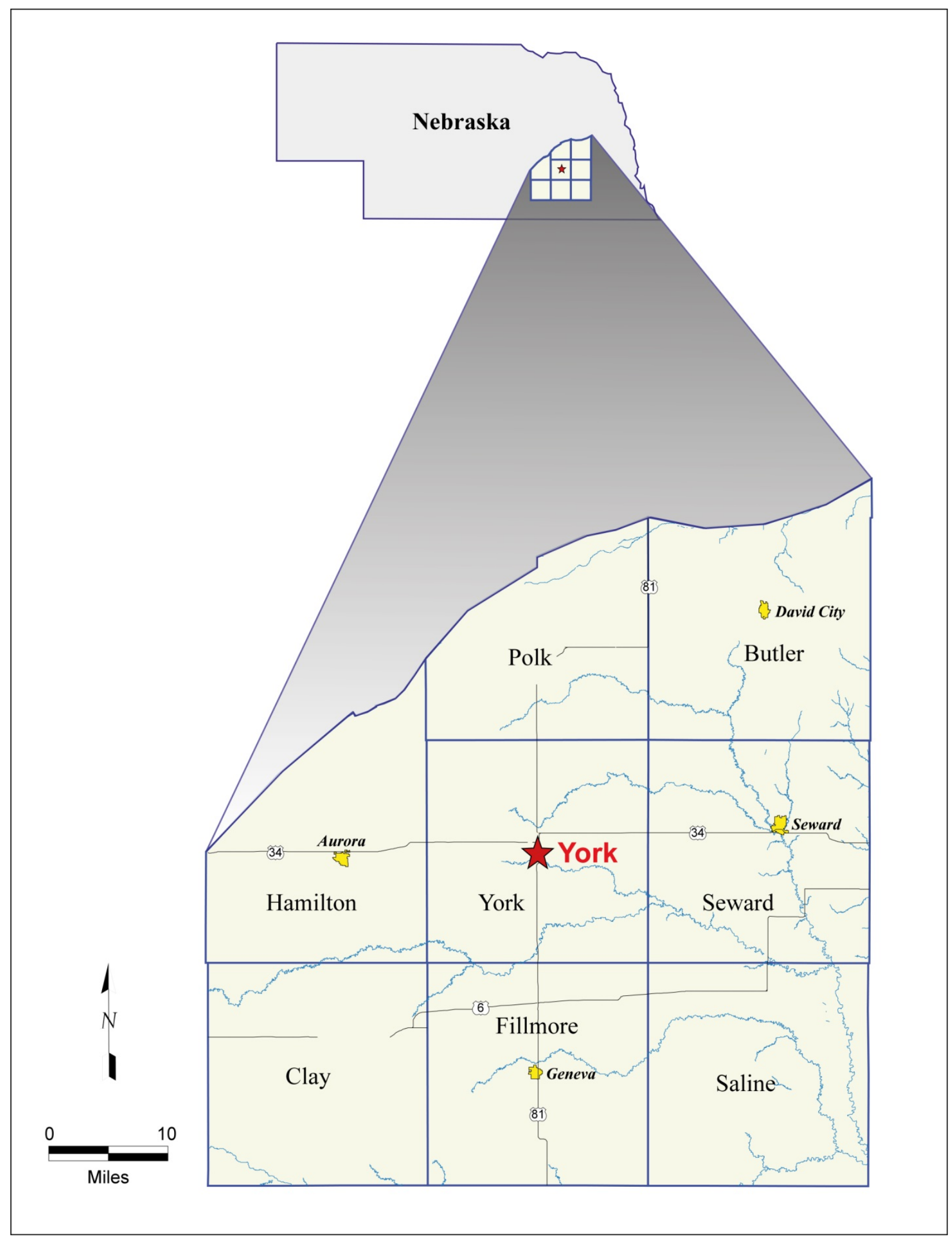

FIGURE 1.1 Location of York, Nebraska. 


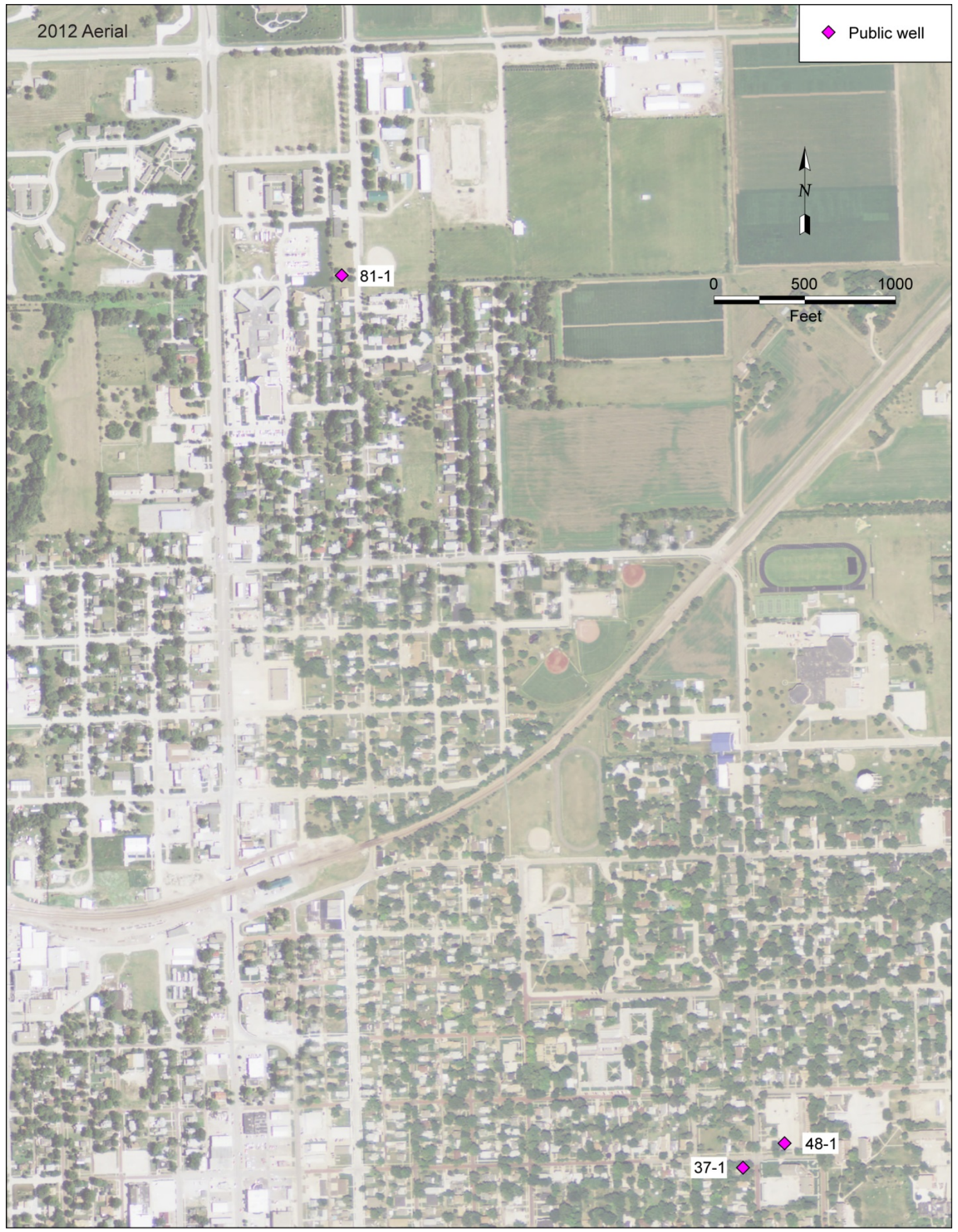

FIGURE 1.2 Locations of contaminated public water supply wells PWS 37-1, PWS 48-1, and PWS 81-1. Source of aerial photograph: USDA (2012). 


\section{Background and Previous Studies}

\subsection{Overview of the Targeted Investigation Area}

The city of York is located in southeast Nebraska, approximately $50 \mathrm{mi}$ west of Lincoln and just north of Interstate 80 (Figure 1.1). York, the county seat, is located in the center of York County and has a population of 7,845 (2012 Census). The area's principal industry is agriculture; corn, soybeans, grain sorghum (milo), and winter wheat are the typical crops. Irrigation is common in the area, and numerous agricultural fields and irrigation wells are located in the general vicinity of the former CCC/USDA facility and the targeted investigation area (Figure 2.1).

The former CCC/USDA facility is in the extreme northern portion of the city (Figure 2.1). Nearby are small businesses and companies supporting agriculture; manufacturing facilities for irrigation and industrial piping, electronic aviation equipment, and prefabricated homes; the York General Hospital and associated nursing and senior care facilities; the York County Fairgrounds; the York Gun Club; the York Area Solid Waste Facility; and a former (closed) pre-Subtitle D landfill. Although several private homes and small apartment complexes are in the proposed study area, the primary residential areas are in the more central and southern portions of York.

\subsubsection{York Public Water Supply}

York is served by a municipal water system that is entirely supplied from groundwater wells. Available information for the York City Water System (NE3118706) indicates that the town currently has 24 public water supply wells. Of these, 19 are identified as active (EPA 2014c). This total includes six wells added to the system in 2009 near the eastern margin of the city, approximately 2-2.5 mi southeast of the former CCC/USDA facility (Figure 2.2; wells PWS 2009-1 through PWS 2009-6).

Construction and status information (as of 2012) for the municipal wells is summarized in Table 2.1. Public wells PWS 37-1, 48-1, 64-1, 73-1, and 81-1 have been decommissioned, and PWS 82-1 and 88-1 are designated for emergency use only. Water is reported as currently being supplied from 16 of the active wells, with a total combined pumping capacity of $6,100 \mathrm{gpm}$ 
(York 2014). The system serves an estimated 8,081 users within the corporate limits of the town, via over 3,300 service connections. Wells PWS 97-1 and 97-1A, the active wells closest to the former CCC/USDA facility, are approximately $1 \mathrm{mi}$ directly south (Figure 2.2).

The NDEQ has developed a wellhead protection area (WHPA) for the public water supply system at York to help prevent contamination of the municipal water supply. To determine the areal limits of the WHPA, a mathematical groundwater flow model (EPA Wellhead Analytical Element Model, WhAEM2000; EPA 2014d) was used to estimate the capture zones - the areas upgradient of the public water supply wells from which groundwater is expected to flow toward each well during simulated periods of up to $20 \mathrm{yr}$. The primary WHPA was developed in December 2010 to consider the estimated pumping of 16 public wells within $3 \mathrm{mi}$ of the city, at a combined rate of approximately 1,760 gpm. For this simulation, the NDEQ-determined groundwater flow is generally to the southeast, on the basis of groundwater levels identified for 21 water wells in the surrounding area. The NDEQ also assumed that the water-producing interval has a uniform saturated thickness of $138 \mathrm{ft}$, hydraulic conductivity of $56 \mathrm{ft} /$ day, and $15 \%$ porosity. A second, separate WHPA was also designated for municipal well PWS 88-1, at a more remote location approximately 4 mi south of the city (Figure 2.2).

The results of the WHPA determination are in Appendix A. The primary WHPA was intentionally drawn slightly larger than the estimated 20-yr time-of-travel groundwater path lines, to allow for uncertainties in the modeled groundwater flow system parameters and to take advantage of existing physical site features and property boundaries that simplify delineation of the WHPA boundary in the field.

The WHPA maps in Appendix A demonstrate that the former CCC/USDA facility (near the intersection of U.S. Highways 34 and 81 at the north edge of the figures) lies generally upgradient of many of the York public supply wells, including the wells installed most recently (in 2004 and 2009), but is beyond the interpreted WHPA boundary and the estimated 20-yr capture zones of all municipal wells included in the simulation. These observations suggest that any carbon tetrachloride contamination that might presently exist at the former CCC/USDA facility is unlikely to pose (within $20 \mathrm{yr}$ ) a threat of contamination to the York municipal water supply. The results of the WHPA evaluation indicate that the predicted 20-yr groundwater migration pathways extending most directly toward the former CCC/USDA facility originate at well PWS 77-1, which is screened at multiple depths in the upper and lower confined aquifers 
(Table 2.1). Groundwater sampling at this well in April 2014 (see Section 2.2.3.2) determined that it is free of carbon tetrachloride contamination.

\subsubsection{Former CCC/USDA Facility and Adjacent Properties}

The property ownership and lease records on file with the York County Registrar of Deeds indicate that the CCC/USDA leased approximately 4.61 acres of property along the western side of Division Avenue in northern York for the purpose of grain storage, from April 1950 until May 1974. The records are reproduced in Supplement 1, on the compact disc (CD) inside the back cover of this report. The property was leased as two separate but adjacent parcels (Figure 2.3) from private owners Aaron and Anna Rauth. On April 1, 1950, an initial lease was established for a parcel of approximately 3.16 acres. On October 1, 1950, a separate lease agreement was established for an additional 1.45 acres. These leases were subsequently extended individually until they were combined into one lease agreement in May 1964. Figures 2.4 and 2.5 indicate that the CCC/USDA facility had reached its maximum known storage capacity 8 large Quonset buildings, 1 large conventional rectangular storage building, 1 smaller Quonset building, and 54 round grain bins — by 1956 and remained unchanged in 1962.

On January 2, 1967, the lease on the smaller (1.45-acre) parcel was terminated. Figure 2.6 shows that by July 1968, all of the round grain bins had been removed from the southern parcel (including 5 bins formerly along the boundary with the northern parcel). Much of the grass cover had been stripped from the southern parcel, possibly for storage of portable anhydrous ammonia tanks.

The CCC/USDA lease on the remaining northern parcel (described as approximately 3 acres) was terminated on May 29, 1974. Figures 2.7-2.9 indicate that by November 1974, 27 of the 30 round grain bins and the smaller Quonset building previously on the property had been removed. Both the northern and southern portions of the property were used for storage of unidentified materials through 1981. Figure 2.10 shows that the remaining 3 round grain bins on the northern portion of the property had been removed by 1988, and usage of the areas formerly occupied by the CCC/USDA round grain bins had apparently decreased. 
Figures 2.10-2.13 show that the structures remaining on the former CCC/USDA facility — the 8 original large Quonset buildings and 1 large conventional storage building did not change in 1988-2012. These structures are still present.

Property records show that the parcels formerly occupied by the CCC/USDA facility remained in the ownership of members of the Rauth family until at least 2002. The property is presently owned by DPKG, LLC, of York, Nebraska. At the time of the CCC/USDA site investigations in 1993-1995, the facilities remaining on the property were being used by the Miller Seed and Supply Company. The detailed usage history of the former southern and northern parcels since the departure of the CCC/USDA (in January 1967 and May 1974, respectively) has not been determined but will be investigated as part of the present study; however, Plains Power, Miogen Seed Company, and Dallas Stauber are reported to have leased the property (EPA 2013a).

No site-specific documentation is available on the detailed usage, handling, or storage of fumigants at the former CCC/USDA grain storage facility at York. General information on former CCC/USDA operations at similar grain storage facilities in Nebraska, Kansas, and Missouri indicates that the liquid fumigant " $80 / 20$," composed of $80 \%$ carbon tetrachloride and $20 \%$ carbon disulfide, was used as necessary for the treatment of grain in storage. No evidence presently available suggests that the CCC/USDA used other fumigant mixtures at these facilities. The fumigant was typically transported to the facilities by truck, in 55-gal drums or smaller (5-gal) containers, and applied to the stored grain by spraying or pouring from the top of the storage structure. The limited information reported for York (EPA 1996) is consistent with this general information.

The property formerly occupied by the CCC/USDA facility is bordered to the north and west by state-owned agricultural land and to the south and southeast by long-term private residences (Preslicka and Cotner, respectively; Figure 2.14). To the east (across Division Avenue) is the York (Ike's) Gun Club, presently owned by the Izaak Walton League. Records for this property (Supplement 1) indicate that it had numerous private owners from the early 1900s until 1946. From 1946 to 1971 it was owned, for uncertain individual periods, by the City of York and York Cold Storage Company (established as a bonded warehouse and cold storage company in 1946, now in business as York Cold Storage, LLC). From 1971 to 1979, the York State Bank and Trust Company was the owner (as trustee). In 1979, the property was transferred from the bank (for \$1.00) to four individuals doing business as the Maken Partners. 
Figures 2.4-2.13 show that the property has been largely vacant and grass-covered since 1956 and has been used as a trap-shooting facility throughout the period of photographic record.

Figure 2.14 shows a large flat storage (warehouse) building on property directly north of the Gun Club and northeast of the former CCC/USDA facility. Available records (Supplement 1) indicate that this property had multiple private owners from the early 1900s until August 1982, when it was deeded (for \$1.00) to the Scoular-Bishop Grain Company, Inc. Subsequently, the property was deeded (for \$1.00) to the Y Grain Company in August 1992 and then to the Farmers Cooperative Association in September 1992. In 1997 the property was obtained by the current owners, Four Clover, LLC. Figures 2.9 and 2.10 indicate that the large storage building was constructed between October 1981 and August 1988, during the period of ownership by Scoular-Bishop. The building is presently used for commercial storage; it contains piping, other supplies and equipment, and several vehicles.

\subsection{Results of Previous CCC/USDA Facility Investigations}

As noted in Section 1, numerous investigations and sampling events conducted in the greater York area since the early 1990s have addressed contamination issues that pose a current or future threat to local private wells and the city's municipal water supply. The majority of these studies, however, have centered on areas south of the former CCC/USDA facility that are impacted by one (or more) of the contaminants TCE, PCE, and 1,1-DCE. These compounds are not associated with the former CCC/USA grain storage operations. The EPA and NDEQ have indicated, in recent discussions, that the CCC/USDA is not required to investigate locations impacted by these additional contaminants (and hence other sources). Rather, the CCC/USDA is to focus on carbon tetrachloride contamination (and potential degradation products chloroform, methylene chloride, and chloromethane) that might be linked to the former CCC/USDA facility.

The most detailed available information regarding the local hydrogeologic setting and the historical distribution of carbon tetrachloride in soils and groundwater at and near the former CCC/USDA facility comes from the CCC/USDA site investigation activities in 1993-1995 and the more recent limited groundwater sampling performed at the request of the EPA and the NDEQ. Information sources resulting from these activities include the following:

- The site characterization Work Plan (Argonne 1993). 
- The Phase I site characterization report (Argonne 1994).

- The Phase II site characterization report (Argonne 1995a).

- The results of additional soil sampling and analysis, aquifer testing, and evaluation of potential remedial alternatives (Argonne 1995b).

- Sampling data for selected private and public wells in 2013-2015, reported here.

These data, supplemented by additional information as appropriate, therefore form the most relevant existing background for the present work and are the basis for the discussions that follow.

\subsubsection{Geologic and Hydrogeologic Setting}

The regional geologic section hosting the primary aquifers of interest in York County is composed of unconsolidated deposits of Quaternary age that range in thickness from approximately $100 \mathrm{ft}$ to $450 \mathrm{ft}$. The uppermost of these units consists of windblown deposits of silt and clay (Peorian and Loveland loess) overlying a sequence of alluvial, fluvial, glacial, and lakebed deposits composed of sands, gravel, silt, and clay. The unconsolidated sediments unconformably overlie Cretaceous-aged bedrock, the uppermost units of which consist of marine shales (Niobrara and Carlile formations) that typically are in excess of several hundred feet thick and act as a basal confining layer for the unconsolidated deposits.

A relatively consistent hydrostratigraphic sequence has been identified in the unconsolidated sediments in the vicinity of York. In keeping with the terminology adopted by the U.S. Geological Survey (USGS; Landon and Turco 2007; Clark et al. 2008; Landon et al. 2008), the principal hydrostratigraphic units of this sequence (in order of increasing depth) include (1) an uppermost predominantly unsaturated interval of silt-clay loess, (2) a laterally continuous unconfined aquifer composed of coarse sands and gravel with lesser interbedded thin layers and lenses of silt and clay, (3) a relatively thick upper confining unit of silty clay and/or silty clay till, and (4) a laterally continuous sandy upper confined aquifer. These units overlie a more heterogeneous zone consisting primarily of clay and silt, with variably interbedded thin 
sandy lenses. These heterogeneous deposits generally form (5) a lower confining unit; however, where locally present, the deeper sandy lenses constitute (6) a lower confined aquifer. Regional average thicknesses of approximately $88 \mathrm{ft}, 72 \mathrm{ft}$, and $33 \mathrm{ft}$ have been estimated, respectively, for the upper unconfined aquifer, the upper confining unit, and the upper confined aquifer, on the basis of available drillers' logs and geophysical information. A predominant direction of groundwater flow to the southeast in both the unconfined and confined aquifers has been determined for the York area; however, localized and/or transient variations in flow direction(s) can occur in the immediate vicinity of pumping wells (Keech et al. 1967; Clark et al. 2008).

More detailed information on the geology and hydrostratigraphy in the immediate vicinity of the former CCC/USDA facility was obtained during the 1993-1995 CCC/USDA studies from an evaluation of available drillers' logs for private and public wells and geologic logs for several state stratigraphic test borings. Other information came from the examination of continuous sediment cores, selectively cored intervals, and direct-push electronic cone penetrometer (CPT) and downhole geophysical logs obtained during these studies. All borings advanced during the 1993-1995 CCC/USDA studies were targeted to investigate the unconfined aquifer only (termed the "upper aquifer"' during those studies). Although several borings were advanced into the top few feet of the upper confining layer, no borings fully penetrated this unit to reach the upper confined aquifer (previously termed the "lower aquifer"). The locations of all wells and borings that provided lithologic control for stratigraphic interpretation in the CCC/USDA studies are shown in Figure 2.15, together with the locations of several interpretive cross sections developed on the basis of this information. The cross sections are shown in Figures 2.16-2.18.

Figures 2.16-2.18 indicate interpreted thicknesses for the surficial loess (silt-clay) unit in the vicinity of the former CCC/USDA facility from approximately $34 \mathrm{ft}$ to a local maximum of approximately $64 \mathrm{ft}$ at boring SB63. The figures also illustrate the relatively complex, locally varying sequence of alternating sand-gravel and silt-clay layers/lenses identified in the interval interpreted to correspond to the regional unconfined aquifer (formerly the "upper aquifer"). The limited groundwater level data obtained for the unconfined aquifer indicated increasing depths to groundwater in the direction of flow (to the south-southeast) ranging from approximately $70 \mathrm{ft}$ BGL beneath the former CCC/USDA facility (at SB01; Figures 2.15 and 2.16) to $86 \mathrm{ft}$ BGL at investigative boring SB29 (Figure 2.15) during the 1993-1995 investigations. Under these groundwater conditions, the saturated thickness of the unconfined aquifer was estimated to be approximately $55-75 \mathrm{ft}$ in the vicinity of the former facility. 
Constant-rate pump testing of the sandier intervals identified in the unconfined aquifer in the immediate vicinity of the former facility (near boring SB62; Figures 2.15 and 2.16), conducted with discrete monitoring of the drawdown responses observed in individual sandy layers, supported an interpretation that the interbedded silt-clay intervals act locally as variably competent, "leaky" confining layers between the individual sand-gravel horizons (Argonne 1995b). Figures 2.16-2.18 illustrate, however, that individual fine-grained layers/lenses in the unconfined aquifer are lithologically variable and laterally discontinuous and generally cannot be correlated with confidence across the 1993-1995 study area. Under non-pumping conditions, no apparent (natural) vertical hydraulic gradients were identified in the pumping test area across the interbedded silt-clay horizons. Figures 2.16-2.18 similarly indicate that the specific lithologic characteristics of the sandy-gravelly intervals in the unconfined aquifer can vary both laterally and vertically over short distances. The latter observations are consistent with previous interpretations of the hydrogeologic characteristics of this unit (Keech et al. 1967; Clark et al. 2008). Because of these complexities, estimates derived from the pumping test data for the hydraulic conductivity of the sand-gravel units in the unconfined aquifer in the vicinity of the former CCC/USDA facility range from approximately 100 to $430 \mathrm{ft} /$ day.

Figures 2.15-2.18 show that the relative abundance of interbedded silt-clay intervals in the unconfined aquifer appears greater (1) immediately to the south and southeast of the former CCC/USDA facility (as represented at irrigation wells G-32619, G-21977, and investigative boring SB63; Figures 2.16-2.17), and (2) in the lower portion of the unconfined aquifer than elsewhere in this unit in the 1993-1995 study area. This observation is tempered, however, by the varying quality of lithologic descriptions available from the drillers' logs that constitute the primary source of lithologic and stratigraphic information for areas beyond the investigative borings advanced during the previous CCC/USDA studies (Argonne 1994, 1995a,b).

Analyses of selected inorganic geochemical parameters were conducted during the 1993$1994 \mathrm{CCC} / \mathrm{USDA}$ investigations to explore the characteristics and distribution of groundwater in the unconfined aquifer. The specific determinations included $\mathrm{pH}$; dissolved oxygen (DO) levels; major anion and cation (metals) concentrations; stable oxygen, hydrogen, and carbon isotope ratios; and tritium levels. Although samples for the analyses were obtained from both investigative borings and selected private wells, no significant interpretations were developed from the private well results because of the absence of well depth and completion data for these locations. 
The results of the analyses for the investigative borings indicated that groundwater throughout the unconfined aquifer in the 1993-1995 area of study was generally oxic (DO = 3-9 mg/L), varied little in $\mathrm{pH}(\mathrm{pH}=6.7-7.6)$, and showed little variation in major element concentrations with location or depth. Carbon isotope ratios for groundwater from the upper portion of the unconfined aquifer were generally higher (less negative) than those for samples from the deeper portion of the unit ( -5.4 to -7.6 per mil versus -7.9 to -15.0 per mil, respectively). Stable oxygen and hydrogen isotope ratios for the unconfined aquifer groundwater generally spanned a relatively wide range (approximately -7 to -9 per mil for oxygen, and -47 to -62 per mil for hydrogen) but were consistent with compositions associated with the Global Meteoric Water Line, suggesting an origin as water derived from surficial sources (precipitation and/or recharge of irrigation water). Together with observed tritium levels, the data suggested that groundwater in the deeper portion of the unconfined aquifer might be somewhat older, and/or derived from a slightly different source, than the groundwater in the shallower portion of this unit. These ranges of $\mathrm{pH}, \mathrm{DO}$, isotope ratios, and relative groundwater age interpretations are generally consistent with those identified by the USGS for groundwater samples from the shallow and deeper portions of the unconfined aquifer in a wider area south and southwest of the former CCC/USDA facility (Landon et al. 2008).

No investigative borings fully penetrated the upper confining unit during the CCC/USDA studies. Interpretations derived from available drilling logs for existing irrigation wells, public water supply wells, and test borings in the vicinity of the former CCC/USDA facility indicate that the top of this unit occurs at approximately 120-160 ft below ground level (BGL) and that it might vary locally in thickness from approximately $30 \mathrm{ft}$ to $90 \mathrm{ft}$. Sediment samples obtained from the top of the upper confining unit at CCC/USDA borings SB01, SB29, and SB36 (Figure 2.15) are consistent with drilling log descriptions indicating that the unit is composed predominantly of gray to "blue" clay, with variable reports of associated pebbles. These observations are consistent with interpretation of the unit as possible glacial clay-till. Regional studies indicate that the upper confining unit represents a competent natural aquitard; however, penetration of this unit by numerous multiply screened private, irrigation, and/or public water supply wells in the York area could provide artificial conduits for significant vertical groundwater and contaminant migration among the unconfined and deeper confined aquifer sands discussed below.

The upper confined aquifer was similarly not penetrated during the CCC/USDA studies. Information from drilling logs for existing wells and test borings in the vicinity of the former 
CCC/USDA facility indicates that a sand-gravel unit of variable thickness representing the upper confined aquifer is consistently present across the area. Multiple sand units interbedded with silts and clays are also indicated, however, at varying depths below the upper confined aquifer; together, these constitute the lower confined aquifer (Clark et al. 2008). Table 2.1 indicates that the York public water supply wells are variably constructed, typically with multiple screened intervals, to tap selected sand and gravel units at each specific well location. The active public wells range in depth from $183 \mathrm{ft}$ BGL (PWS 62-1) to $388 \mathrm{ft}$ BGL (PWS 97-2). Table 2.1 indicates that with only one exception (PWS 62-1), the municipal wells in unrestricted use draw groundwater either exclusively from the lower confined aquifer or from both the upper and lower confined aquifers.

\subsubsection{Carbon Tetrachloride Distribution in Soils}

\subsubsection{Results for Shallow Soils and Vegetation}

To understand the potential distribution of carbon tetrachloride in the surface and shallow subsurface soils at the former CCC/USDA facility, soil samples were collected from the uppermost (A-1) soil horizon on a grid with spacing approximately $50 \mathrm{ft}$ by $50 \mathrm{ft}$ across the site (Argonne 1995b). The samples were analyzed for carbon tetrachloride and chloroform with a screening method - headspace analysis on a gas chromatograph-electron capture detector (GCECD) system (modified EPA Method 5021). During these studies, Argonne was exploring the headspace method as a screening technique to permit fairly rapid analyses of both soil and vegetation samples (typically within $24 \mathrm{hr}$ of collection) with high sensitivity to low concentrations. Subsequent studies have demonstrated the capabilities of this screening technique (Alvarado and Rose 2004). The results of the headspace analyses (Table 2.2 and Figure 2.19) were compared to determine spatial patterns of higher headspace concentrations in the shallow soils, as a means to prioritize locations for further investigation.

On the basis of the headspace analyses, additional soil samples were collected at 18 locations, at depths of 0.5-0.7 ft, 0.7-2.0 ft, and 2-4 ft BGL, for analyses with the more rigorous EPA Contract Laboratory Program (CLP) methods with a gas chromatograph-mass spectrometer (GC-MS) system (Argonne 1995b). The results of the CLP analyses (Table 2.2 and Figure 2.20) identified concentrations of carbon tetrachloride in the shallow soils ( $\leq 4 \mathrm{ft}$ BGL) exceeding the present NDEQ Voluntary Cleanup Program (VCP) target for this contaminant in soils (39 $\mu \mathrm{g} / \mathrm{kg}$, 
for protection of the soil-to-groundwater pathway) at three locations near several of the remaining (or former) CCC/USDA Quonset buildings in the central portion of the former facility.In conjunction with the investigation at York, samples of selected plants growing at the former CCC/USDA facility and on the Gun Club property, immediately east of the former facility, were collected for VOCs analyses (Argonne 1994). The results of these analyses, illustrated in Figure 2.21, identified elevated levels of carbon tetrachloride and chloroform in vegetation at selected locations on both properties.

\subsubsection{Results for Deeper Subsurface Soils}

Deeper subsurface soil samples were collected in 1993 for VOCs analyses at the seven locations shown in Figure 2.22 (Argonne 1994, 1995b). The samples were collected (1) in fairly continuous vertical profiles at locations SB01, SB62, and CPT37 to investigate for possible carbon tetrachloride contamination in the vadose zone on and near the former CCC/USDA facility, and (2) selectively with depth from fine-grained horizons identified primarily in the saturated zone at borings SB36, SB63, SB67, and SB70, southeast of the former CCC/USDA facility. Sample aliquots preserved dry at $4^{\circ} \mathrm{C}$ or with methanol at $4^{\circ} \mathrm{C}$ were analyzed by an onsite laboratory. Approximately $10 \%$ of the samples were also shipped to an off-site laboratory for analysis with EPA CLP methods. Table 2.3 presents the analytical results from the on-site laboratory for samples preserved with methanol, which consistently returned higher contaminant values than did the corresponding aliquots that were collected dry.

Figure 2.23 summarizes the distribution of carbon tetrachloride and chloroform in the vadose zone soils at vertical-profile locations SB62, CPT37, and SB01. Carbon tetrachloride concentrations exceeding the current NDEQ VCP target for this contaminant in soils $(39 \mu \mathrm{g} / \mathrm{kg}$, for protection of the soil-to-groundwater pathway) were detected at both of the locations tested on the former CCC/USDA property (SB01 and CPT37; Figure 2.22). At boring SB01, the carbon tetrachloride levels identified were $89-111 \mu \mathrm{g} / \mathrm{kg}$ in the near-surface soils (0.6-2.5 $\mathrm{ft}$ BGL) and 73-772 $\mu \mathrm{g} / \mathrm{kg}$ over the depth interval 12.6-40 ft BGL. Sporadic elevated concentrations occurred in isolated samples at greater depths. A generally similar vertical distribution of carbon tetrachloride was identified at the SB37/CPT37 boring, at lower overall concentrations (maximum $281 \mu \mathrm{g} / \mathrm{kg}$ at approximately $24 \mathrm{ft}$ BGL; Figure 2.23). The vertical profiles at both SB01 and SB37/CPT37 suggested that carbon tetrachloride was preferentially associated with the finer-grained sediments (loess) overlying the sands hosting the upper unconfined aquifer. 
Figure 2.23 illustrates the relatively low concentrations of carbon tetrachloride detected in the vadose zone soils at boring SB62 on the Gun Club property (46-49 $\mu \mathrm{g} / \mathrm{kg}$, exceeding the current NDEQ VCP target) in two samples collected over the isolated depth range 38-41 ft BGL. A potential source for this contamination could not be positively identified. Discussions with local residents at the time of the studies indicated, however, that a contaminated well on the Gun Club property had previously been used for irrigation of this land; this might have resulted in the observed soil contamination.

Carbon tetrachloride was detected at trace levels only $(<10 \mu \mathrm{g} / \mathrm{kg})$ in isolated samples collected from the deep interbedded silt-clay units at boring locations SB36, SB63, SB67, and SB70 (Table 2.3 and Figure 2.22).

Table 2.3 and Figure 2.23 indicate that high levels of chloroform relative to the associated concentrations of carbon tetrachloride $(>10 \%$ to $>100 \%$, calculated as chloroform/carbon tetrachloride) were detected in many of the subsurface soil samples collected at SB01, SB37/CPT37, and SB62. These relationships provide evidence for degradation of carbon tetrachloride in the soils via natural reductive dechlorination processes.

The elevated carbon tetrachloride concentrations identified in the deeper soils at the SB01, SB37/CPT37, and SB62 locations coincide with the isolated "hot spots" identified in the shallow soils and vegetation on the basis of the headspace screening and the follow-up CLP analyses discussed in Section 2.2.2.1. The areal extents of the carbon tetrachloride contamination in the vadose zone soils at the former CCC/USDA facility and the Gun Club property were not fully delineated, however, by deep soil sampling and VOCs analyses.

\subsubsection{Carbon Tetrachloride Distribution in Groundwater}

\subsubsection{CCC/USDA Groundwater Sampling in 1993}

To determine the areal extent of the carbon tetrachloride contamination in groundwater apparently associated with the former CCC/USDA grain storage operations, samples for the determination of VOCs (including carbon tetrachloride, chloroform, TCE, PCE, and additional VOCs) were collected in 1993 from numerous sources, including selected private wells, public water supply wells, and drilled and direct-push investigative borings (Argonne 1994). At the 
investigative borings, groundwater samples were typically collected at selected multiple depths to determine the vertical contaminant distribution in the unconfined aquifer unit. The groundwater sampling locations for these studies are in Figures 2.24 and 2.25. The analytical results for VOCs are in Table 2.4. The lateral extent of carbon tetrachloride interpreted to be associated with the former CCC/USDA facility is shown in Figure 2.26.

Carbon tetrachloride was detected in the unconfined aquifer groundwater to a maximum distance of approximately 4,000 $\mathrm{ft}$ to the southeast (downgradient) from the former CCC/USDA facility. The highest carbon tetrachloride concentrations identified (1,566-1,990 $\mu \mathrm{g} / \mathrm{L})$ occurred beneath or within approximately $500 \mathrm{ft}$ of the former facility, at boring locations CPT3, SB01, SB62, and SB64, primarily in the upper portion of the saturated interval. Carbon tetrachloride concentrations declined to the southeast, to $158 \mu \mathrm{g} / \mathrm{L}$ at boring location SB63, approximately $2,000 \mathrm{ft}$ southeast of the former facility. Chloroform was not detected in groundwater at any location above the MCL for this contaminant $(80 \mu \mathrm{g} / \mathrm{L})$.

Figure 2.26 and Table 2.4 indicate that trace to low levels of carbon tetrachloride contamination $(\leq 13 \mu \mathrm{g} / \mathrm{L})$ were identified in groundwater along a second, separate trend extending southeastward from near the intersection of 25th Street and Division Avenue, in association with additional volatile contaminants (primarily TCE and PCE) that are unrelated to the use of fumigants at the former CCC/USDA facility. The location and spatial trend of this second (multi-contaminant) plume (Figure 2.26) are consistent with contamination subsequently linked by the EPA to the PCE/TCE Northeast Contamination NPL site, as discussed in Section 1. The EPA has indicated that the CCC/USDA is not responsible for the investigation of area(s) impacted by multiple VOCs (other than carbon tetrachloride and its potential degradation products) in the vicinity of the former CCC/USDA grain storage facility.

The vertical distribution of carbon tetrachloride identified in groundwater near the former CCC/USDA facility (Table 2.4) demonstrates that some downward migration of this contaminant has occurred across the interbedded silt-clay layers (Figures 2.16-2.18) and into the deeper portions of the unconfined aquifer. Lower levels of carbon tetrachloride, ranging from $1 \mu \mathrm{g} / \mathrm{L}$ to $63 \mu \mathrm{g} / \mathrm{L}$, were detected in groundwater within and below the silt-clay layers. The lateral and vertical variations observed in carbon tetrachloride concentrations in groundwater were inferred to be, in part, an artifact of possible influences of pumping wells, coupled with variations in the continuity and hydraulic characteristics of the individual silt-clay and sand-gravel layers and lenses in the unconfined aquifer. 


\subsubsection{CCC/USDA Sampling of Selected Wells in 2013-2015}

At the request of the EPA and the NDEQ, the CCC/USDA sampled a number of private wells and two York municipal supply wells in June 2013, April 2014, and July 2014 for analyses for carbon tetrachloride and its degradation products. This sampling was performed in conjunction with groundwater sampling by the EPA and NDEQ for multiple additional contaminants, to address the wider-area contamination in groundwater identified in the more central and southern portions of York. The locations of the wells sampled by the CCC/USDA are in Figure 2.27, with the maximum carbon tetrachloride concentration at each location. The complete results of the analyses for VOCs are in Table 2.5. In June 2013-July 2014, no carbon tetrachloride was detected at any of the sampled locations at levels exceeding the MCL for this contaminant in groundwater $(5.0 \mu \mathrm{g} / \mathrm{L})$. Low levels of carbon tetrachloride were detected, however, at the Olson and co-op private wells $(2.2 \mu \mathrm{g} / \mathrm{L}$ and $2.3 \mu \mathrm{g} / \mathrm{L}$, respectively; Table 2.5).

Quarterly monitoring of selected private and public wells has subsequently been implemented by the CCC/USDA, at the request of the EPA and the NDEQ. The results of VOCs analyses for groundwater samples collected in December 2014 and March 2015 are included in Table 2.5. Carbon tetrachloride was identified at levels slightly below or slightly above the MCL for this contaminant in the Olson and co-op private wells, at concentrations of $7.4 \mu \mathrm{g} / \mathrm{L}$ and $4.9 \mu \mathrm{g} / \mathrm{L}$, respectively, in December 2014 and $2.4 \mu \mathrm{g} / \mathrm{L}$ and $5.1 \mu \mathrm{g} / \mathrm{L}$, respectively, in March 2015. On the basis of these findings, the CCC/USDA has initiated actions to connect the former Olson residence (now owned by Kayton) to the York municipal water supply, at the request of the property owner, the EPA, and the NDEQ. 
TABLE 2.1 Construction and status of the York municipal supply wells.

\begin{tabular}{|c|c|c|c|c|c|}
\hline $\begin{array}{c}\text { Well } \\
\text { Number }\end{array}$ & $\begin{array}{l}\text { Registration } \\
\text { Number }\end{array}$ & $\begin{array}{c}\text { Total } \\
\text { Depth } \\
\text { (ft BGL) }\end{array}$ & $\begin{array}{l}\text { Screened } \\
\text { Interval(s) } \\
\text { (ft BGL) }\end{array}$ & $\begin{array}{c}\text { Screened } \\
\text { Aquifer(s) }^{\mathrm{a}}\end{array}$ & $\begin{array}{c}\text { Status } \\
\text { (as of 2012) }\end{array}$ \\
\hline $37-1$ & G-030562 & 116 & $100-116(?)^{b}$ & Unc & Decommissioned \\
\hline $48-1$ & G-030561 & 135 & $\begin{array}{l}100-120 \\
125-135\end{array}$ & Unc & Decommissioned \\
\hline $62-1$ & G-030563 & 183 & 103-183 (?) & Unc, Ucf & Active \\
\hline $64-1$ & $N A^{c}$ & NA & 318 & NA & Decommissioned \\
\hline $68-1$ & G-030559 & 356 & 167-(?) & Ucf, Lcf & Active \\
\hline $73-1$ & G-063043 & 394 & $\begin{array}{l}159-219 \\
266-271 \\
277-282 \\
314-319 \\
330-335 \\
344-374 \\
389-394\end{array}$ & Ucf, Lcf & Decommissioned \\
\hline $76-1$ & G-063042 & 196 & $125-195$ & Lcf & Active \\
\hline $77-1$ & G-060709 & 380 & $\begin{array}{l}180-230 \\
255-310 \\
360-380\end{array}$ & Ucf, Lcf & Active \\
\hline $77-3$ & G-060708 & 292 & $\begin{array}{l}150-205 \\
272-292\end{array}$ & Ucf, Lcf & Active \\
\hline $77-4$ & G-060707 & $200^{d}$ & $141-200^{d}$ & Ucf & Active \\
\hline $81-1$ & G-063044 & 385 & $\begin{array}{l}145-160 \\
205-235 \\
265-300 \\
320-330 \\
335-340 \\
375-385\end{array}$ & $\begin{array}{l}\text { Unc, Ucf, } \\
\text { Lcf }\end{array}$ & Decommissioned \\
\hline $82-1$ & G-030560A & 368 & $\begin{array}{l}173-233 \\
263-368\end{array}$ & Ucf, Lcf & $\begin{array}{c}\text { Active } \\
\text { (Emergency Only) }\end{array}$ \\
\hline $82-2$ & G-030560B & 340 & $\begin{array}{l}170-235 \\
270-285 \\
300-340\end{array}$ & Ucf, Lcf & Active \\
\hline 88-1 & G-071287 & 274 & $\begin{array}{l}129-154 \\
192-212 \\
254-274\end{array}$ & Unc, Ucf & $\begin{array}{c}\text { Active } \\
\text { (Emergency Only) }\end{array}$ \\
\hline $97-1$ & G-094218 & 386 & 283-362 & Lcf & Active \\
\hline $97-1 \mathrm{~A}$ & G-094220 & 233 & $167-228$ & Ucf & Active \\
\hline
\end{tabular}


TABLE 2.1 (Cont.)

\begin{tabular}{|c|c|c|c|c|c|}
\hline $\begin{array}{l}\text { Well } \\
\text { Number }\end{array}$ & $\begin{array}{l}\text { Registration } \\
\text { Number }\end{array}$ & $\begin{array}{l}\text { Total } \\
\text { Depth } \\
\text { (ft BGL) }\end{array}$ & $\begin{array}{c}\text { Screened } \\
\text { Interval(s) } \\
\text { (ft BGL) }\end{array}$ & $\begin{array}{c}\text { Screened } \\
\text { Aquifer(s) }^{\mathrm{a}}\end{array}$ & $\begin{array}{c}\text { Status } \\
\text { (as of 2012) }\end{array}$ \\
\hline $97-2$ & G-094219 & 388 & $\begin{array}{l}278-290 \\
298-328 \\
338-388\end{array}$ & Lcf & Active \\
\hline 2004-1 & G-130246 & 383 & $\begin{array}{l}270-280 \\
338-373\end{array}$ & Lcf & Active \\
\hline 2009-1 & G-157272 & 326 & $\begin{array}{l}269-279 \\
296-326\end{array}$ & Lcf & Active \\
\hline $2009-2$ & G-157274 & 349 & $\begin{array}{l}263-274 \\
305-347\end{array}$ & Lcf & Active \\
\hline $2009-3$ & G-157275 & 376 & $\begin{array}{l}265-280 \\
305-376\end{array}$ & Lcf & Active \\
\hline $2009-4$ & G-157276 & 392 & $\begin{array}{l}270-314 \\
342-392\end{array}$ & Lcf & Active \\
\hline 2009-5 & G-157277 & 375 & $\begin{array}{l}255-265 \\
283-339 \\
365-375\end{array}$ & Lcf & Active \\
\hline $2009-6$ & G-157273 & 375 & $\begin{array}{l}261-271 \\
333-375\end{array}$ & Lcf & Active \\
\hline
\end{tabular}

a Aquifer designations based on interpretations reported by the USGS (Landon and Turco 2007; Clark et al. 2008) and Tetra Tech (2012c):

Unc, unconfined aquifer

Ufc , upper confined aquifer

Lfc , lower confined aquifer

b (?), information unknown or unconfirmed.

c NA, not available.

d An additional, deeper screened interval was reported as grouted by the USGS (Landon et al. 2008). 
TABLE 2.2 Organic analysis results for shallow soil samples, 1994-1995.

\begin{tabular}{|c|c|c|c|c|c|c|c|c|c|}
\hline \multirow[b]{4}{*}{ Date } & & & \multirow[b]{4}{*}{ Sample } & \multirow[b]{4}{*}{$\begin{array}{l}\text { Depth } \\
\text { (ft BGL) }\end{array}$} & \multicolumn{5}{|c|}{ Concentration $(\mu \mathrm{g} / \mathrm{kg})$} \\
\hline & & & & & \multicolumn{2}{|c|}{ GC-ECD ${ }^{b}$} & \multicolumn{3}{|c|}{ GC-MS (CLP) ${ }^{\mathrm{C}}$} \\
\hline & \multicolumn{2}{|c|}{ Location $^{\mathrm{a}}$} & & & \multirow[b]{2}{*}{$\begin{array}{c}\text { Carbon } \\
\text { Tetrachloride }\end{array}$} & \multirow[b]{2}{*}{ Chloroform } & \multirow[b]{2}{*}{$\begin{array}{c}\text { Carbon } \\
\text { Tetrachloride }\end{array}$} & \multirow[b]{2}{*}{ Chloroform } & \multirow[b]{2}{*}{$\begin{array}{c}\text { Quantitation } \\
\text { Limit }\end{array}$} \\
\hline & North & West & & & & & & & \\
\hline Sep 94 & 10 & 10 & YKSS492422V & & 0.09 & $<0.07$ & & & \\
\hline Sep 94 & 10 & 50 & YKSS012372V & & 0.13 & $<0.04$ & & & \\
\hline Sep 94 & 10 & 100 & YKFTRT2375V & & 0.13 & $<0.06$ & & & \\
\hline Sep 94 & 10 & 150 & YKSS032376V & & 0.16 & $<0.05$ & & & \\
\hline Sep 94 & 10 & 200 & YKSS042377V & & 0.18 & $<0.08$ & & & \\
\hline Sep 94 & 50 & 10 & YKSS502423V & & 0.06 & 0.26 & & & \\
\hline Sep 94 & 50 & 200 & YKSS052378V & & 0.14 & $<0.06$ & & & \\
\hline Sep 94 & 100 & 10 & YKSS092378V & & 0.12 & $<0.06$ & & & \\
\hline Mar 95 & 100 & 27 & YKSB88-S-04300 & $0.5-0.7$ & & & $N D^{d}$ & ND & 12 \\
\hline Mar 95 & 100 & 27 & YKSB88-S-04301 & 2 & & & ND & ND & 12 \\
\hline Sep 94 & 100 & 100 & YKSS082386V & & 1.48 & 1.53 & & & \\
\hline Oct 94 & 100 & 100 & YKSB87-S-02712 & $0.5-0.7$ & & & ND & ND & 23 \\
\hline Oct 94 & 100 & 100 & YKSB87-S-02713 & $0.7-2$ & & & ND & ND & 25 \\
\hline Oct 94 & 100 & 100 & YKSB87-S-02714 & $2-4$ & & & ND & ND & 23 \\
\hline Sep 94 & 100 & 150 & YKSS072385V & & 0.42 & $<0.14$ & & & \\
\hline Sep 94 & 100 & 200 & YKSS062384V & & 0.09 & $<0.05$ & & & \\
\hline Mar 95 & 110 & 30 & YKSB89-S-04302 & $0.5-0.7$ & & & ND & ND & 11 \\
\hline Mar 95 & 110 & 30 & YKSB89-S-04303 & 2 & & & ND & ND & 12 \\
\hline Sep 94 & 150 & 10 & YKSS512424V & & 0.1 & $<0.05$ & & & \\
\hline Sep 94 & 200 & 10 & YKSS102388V & & 0.08 & $<0.07$ & & & \\
\hline Oct 94 & 200 & 100 & YKSB86-S-02709 & $0.5-0.7$ & & & ND & ND & 22 \\
\hline Oct 94 & 200 & 100 & YKSB86-S-02710 & $0.7-2$ & & & ND & ND & 27 \\
\hline Oct 94 & 200 & 100 & YKSB86-S-02711 & $2-4$ & & & ND & ND & 25 \\
\hline Sep 94 & 200 & 150 & YKSS112389V & & 1.54 & 0.21 & & & \\
\hline Sep 94 & 200 & 200 & YKSS122390V & & 0.14 & $<0.06$ & & & \\
\hline
\end{tabular}


TABLE 2.2 (Cont.)

\begin{tabular}{|c|c|c|c|c|c|c|c|c|c|}
\hline \multirow[b]{4}{*}{ Date } & & & \multirow[b]{4}{*}{ Sample } & \multirow[b]{4}{*}{$\begin{array}{l}\text { Depth } \\
\text { (ft BGL) }\end{array}$} & \multicolumn{5}{|c|}{ Concentration $(\mu \mathrm{g} / \mathrm{kg})$} \\
\hline & & & & & \multicolumn{2}{|c|}{$G C-E C D^{b}$} & \multicolumn{3}{|c|}{ GC-MS $(C L P)^{c}$} \\
\hline & \multicolumn{2}{|c|}{ Location $^{\mathrm{a}}$} & & & \multirow[b]{2}{*}{$\begin{array}{c}\text { Carbon } \\
\text { Tetrachloride }\end{array}$} & \multirow[b]{2}{*}{ Chloroform } & \multirow[b]{2}{*}{$\begin{array}{c}\text { Carbon } \\
\text { Tetrachloride }\end{array}$} & \multirow[b]{2}{*}{ Chloroform } & \multirow[b]{2}{*}{$\begin{array}{c}\text { Quantitation } \\
\text { Limit }\end{array}$} \\
\hline & North & West & & & & & & & \\
\hline Sep 94 & 250 & 10 & YKSS522425V & & 0.39 & 0.11 & & & \\
\hline Sep 94 & 250 & 100 & YKSS542427V & & 1.14 & 0.15 & & & \\
\hline Sep 94 & 250 & 150 & YKSS562429V & & 0.68 & 0.14 & & & \\
\hline Sep 94 & 250 & 200 & YKSS572430V & & 0.12 & 0.13 & & & \\
\hline Sep 94 & 300 & 10 & YKSS532426V & & 0.15 & $<0.07$ & & & \\
\hline Sep 94 & 350 & 10 & YKSS172383V & & 0.51 & 0.57 & & & \\
\hline Sep 94 & 350 & 50 & YKSS162382V & & 0.66 & 0.59 & & & \\
\hline Sep 94 & 350 & 100 & YKSS152381V & & 0.07 & 0.19 & & & \\
\hline Sep 94 & 350 & 150 & YKSS142380V & & 0.1 & $<0.06$ & & & \\
\hline Sep 94 & 350 & 200 & YKSS132379V & & 0.1 & $<0.05$ & & & \\
\hline Sep 94 & 400 & 10 & YKSS182391V & & 9.04 & 2.44 & & & \\
\hline Oct 94 & 400 & 10 & YKSB85-S-02706 & $0.5-0.7$ & & & ND & ND & 38 \\
\hline Oct 94 & 400 & 10 & YKSB85-S-02707 & $0.7-2$ & & & ND & ND & 27 \\
\hline Oct 94 & 400 & 10 & YKSB85-S-02708 & $2-4$ & & & ND & ND & 24 \\
\hline Mar 95 & 400 & 10 & YKSB90-S-04304 & $0.5-0.7$ & & & 20 & ND & 13 \\
\hline Mar 95 & 400 & 10 & YKSB90-S-04305 & $2-2.5$ & & & 16 & ND & 13 \\
\hline Mar 95 & 400 & 18 & YKSB91-S-04306 & $0.5-0.7$ & & & 17 & ND & 13 \\
\hline Mar 95 & 400 & 18 & YKSB91-S-04307 & 2 & & & 19 & ND & 12 \\
\hline Sep 94 & 400 & 65 & YKSS192392V & & 0.73 & 0.42 & & & \\
\hline Sep 94 & 400 & 100 & YKSS202393V & & 0.15 & $<0.08$ & & & \\
\hline Sep 94 & 400 & 150 & YKSS212394V & & 0.56 & 0.12 & & & \\
\hline Sep 94 & 400 & 200 & YKSS222395V & & 0.12 & $<0.07$ & & & \\
\hline Sep 94 & 450 & 5 & YKSS272400V & & 15.81 & 2.3 & & & \\
\hline Oct 94 & 450 & 10 & YKSB75-S-02677 & $0.5-0.7$ & & & 67 & ND & 32 \\
\hline Oct 94 & 450 & 10 & YKSB75-S-02678 & $0.7-2$ & & & 82 & ND & 24 \\
\hline Oct 94 & 450 & 10 & YKSB75-S-02679 & $2-4$ & & & ND & ND & 24 \\
\hline Oct 94 & 450 & 50 & YKSB76-S-02680 & $0.5-0.7$ & & & ND & ND & 24 \\
\hline Oct 94 & 450 & 50 & YKSB76-S-02681 & $0.7-2$ & & & ND & ND & 26 \\
\hline Oct 94 & 450 & 50 & YKSB76-S-02682 & $2-4$ & & & ND & ND & 26 \\
\hline Sep 94 & 450 & 60 & YKSS262399V & & 0.37 & $<0.08$ & & & \\
\hline
\end{tabular}


TABLE 2.2 (Cont.)

\begin{tabular}{|c|c|c|c|c|c|c|c|c|c|}
\hline \multirow[b]{4}{*}{ Date } & & & \multirow[b]{4}{*}{ Sample } & \multirow[b]{4}{*}{$\begin{array}{l}\text { Depth } \\
\text { (ft BGL) }\end{array}$} & \multicolumn{5}{|c|}{ Concentration $(\mu \mathrm{g} / \mathrm{kg})$} \\
\hline & & & & & \multicolumn{2}{|c|}{ GC-ECD ${ }^{b}$} & \multicolumn{3}{|c|}{ GC-MS (CLP) ${ }^{\mathrm{C}}$} \\
\hline & \multicolumn{2}{|c|}{ Location $^{\mathrm{a}}$} & & & & & & & \\
\hline & North & West & & & $\begin{array}{c}\text { Carbon } \\
\text { Tetrachloride }\end{array}$ & Chloroform & $\begin{array}{c}\text { Carbon } \\
\text { Tetrachloride }\end{array}$ & Chloroform & $\begin{array}{c}\text { Quantitation } \\
\text { Limit }\end{array}$ \\
\hline Sep 94 & 450 & 100 & YKSS252398V & & 0.49 & 0.24 & & & \\
\hline Oct 94 & 450 & 100 & YKSB77-S-02683 & $0.5-0.7$ & & & ND & ND & 27 \\
\hline Oct 94 & 450 & 100 & YKSB77-S-02684 & $0.7-2$ & & & ND & ND & 23 \\
\hline Oct 94 & 450 & 100 & YKSB77-S-02685 & $2-4$ & & & ND & ND & 22 \\
\hline Sep 94 & 450 & 150 & YKSS242397V & & 0.5 & 0.14 & & & \\
\hline Oct 94 & 450 & 150 & YKSB78-S-02686 & $0.5-0.7$ & & & ND & ND & 27 \\
\hline Oct 94 & 450 & 150 & YKSB78-S-02687 & $0.7-2$ & & & ND & ND & 24 \\
\hline Oct 94 & 450 & 150 & YKSB78-S-02688 & $2-4$ & & & ND & ND & 23 \\
\hline Sep 94 & 450 & 200 & YKSS232396V & & 0.29 & $<0.06$ & & & \\
\hline Oct 94 & 450 & 200 & YKSB79-S-02715 & $0.5-0.7$ & & & ND & ND & 27 \\
\hline Oct 94 & 450 & 200 & YKSB79-S-02716 & $0.7-2$ & & & ND & ND & 22 \\
\hline Oct 94 & 450 & 200 & YKSB79-S-02717 & $2-4$ & & & ND & ND & 24 \\
\hline Sep 94 & 500 & 5 & YKSS282401V & & 2.34 & 0.75 & & & \\
\hline Mar 95 & 500 & 10 & YKSB92-S-04308 & $0.5-0.7$ & & & ND & ND & 12 \\
\hline Mar 95 & 500 & 10 & YKSB92-S-04309 & 2 & & & ND & ND & 13 \\
\hline Sep 94 & 500 & 50 & YKSS292402Vd & & 1.28 & 0.53 & & & \\
\hline Sep 94 & 500 & 100 & YKSS302403V & & 0.29 & 0.31 & & & \\
\hline Oct 94 & 500 & 100 & YKSB80-S-02689 & $0.5-0.7$ & & & ND & ND & 22 \\
\hline Oct 94 & 500 & 100 & YKSB80-S-02690 & $0.7-2$ & & & ND & ND & 27 \\
\hline Oct 94 & 500 & 100 & YKSB80-S-02691 & $2-4$ & & & ND & ND & 25 \\
\hline Sep 94 & 500 & 150 & YKSS312404V & & 1.05 & 0.29 & & & \\
\hline Sep 94 & 500 & 200 & YKSS322405V & & 0.35 & 0.12 & & & \\
\hline Sep 94 & 550 & 5 & YKSS372410V & & 0.1 & $<0.05$ & & & \\
\hline Sep 94 & 550 & 50 & YKSS362409V & & 0.12 & $<0.08$ & & & \\
\hline Sep 94 & 550 & 100 & YKSS352408V & & 0.35 & $<0.19$ & & & \\
\hline Oct 94 & 550 & 100 & YKSB81-S-02694 & $0.5-0.7$ & & & ND & ND & 24 \\
\hline Oct 94 & 550 & 100 & YKSB81-S-02695 & $0.7-2$ & & & ND & ND & 26 \\
\hline Oct 94 & 550 & 100 & YKSB81-S-02696 & $2-4$ & & & ND & ND & 24 \\
\hline Sep 94 & 550 & 150 & YKSS342407V & & 0.71 & $<0.06$ & & & \\
\hline Sep 94 & 550 & 200 & YKSS332406V & & 0.55 & $<0.06$ & & & \\
\hline
\end{tabular}


TABLE 2.2 (Cont.)

\begin{tabular}{|c|c|c|c|c|c|c|c|c|c|}
\hline \multirow[b]{4}{*}{ Date } & & & \multirow[b]{4}{*}{ Sample } & \multirow[b]{4}{*}{$\begin{array}{c}\text { Depth } \\
\text { (ft BGL) }\end{array}$} & \multicolumn{5}{|c|}{ Concentration $(\mu \mathrm{g} / \mathrm{kg})$} \\
\hline & & & & & \multicolumn{2}{|c|}{ GC-ECD ${ }^{b}$} & \multicolumn{3}{|c|}{ GC-MS (CLP) ${ }^{\mathrm{C}}$} \\
\hline & \multicolumn{2}{|c|}{ Location $^{a}$} & & & & & & & \\
\hline & North & West & & & $\begin{array}{c}\text { Carbon } \\
\text { Tetrachloride }\end{array}$ & Chloroform & $\begin{array}{c}\text { Carbon } \\
\text { Tetrachloride }\end{array}$ & Chloroform & $\begin{array}{c}\text { Quantitation } \\
\text { Limit }\end{array}$ \\
\hline Sep 94 & 600 & 5 & YKSS432416V & & 0.34 & $<0.05$ & & & \\
\hline Oct 94 & 600 & 100 & YKSB82-S-02697 & $0.5-0.7$ & & & ND & ND & 32 \\
\hline Oct 94 & 600 & 100 & YKSB82-S-02698 & $0.7-2$ & & & 32 & ND & 24 \\
\hline Oct 94 & 600 & 100 & YKSB82-S-02699 & $2-4$ & & & ND & ND & 27 \\
\hline Oct 94 & 600 & 150 & YKSB83-S-02700 & $0.5-0.7$ & & & ND & ND & 34 \\
\hline Oct 94 & 600 & 150 & YKSB83-S-02701 & $0.7-2$ & & & ND & ND & 21 \\
\hline Oct 94 & 600 & 150 & YKSB83-S-02702 & $2-4$ & & & ND & ND & 24 \\
\hline Sep 94 & 600 & 205 & YKSS382411V & & 0.48 & $<0.05$ & & & \\
\hline Sep 94 & 625 & 100 & YKSS582431V & & 15.2 & 3.99 & & & \\
\hline Mar 95 & 625 & 100 & YKSB95-S-04314 & $0.5-0.7$ & & & 77 & ND & 13 \\
\hline Mar 95 & 625 & 100 & YKSB95-S-04315 & 1.5 & & & 89 & ND & 12 \\
\hline Mar 95 & 625 & 125 & YKSB96-S-04316 & $0.5-0.7$ & & & 14 & ND & 13 \\
\hline Mar 95 & 625 & 125 & YKSB96-S-04317 & $1.5-2$ & & & 30 & ND & 12 \\
\hline Sep 94 & 625 & 150 & YKSS592432V & & 8.45 & 2.4 & & & \\
\hline Mar 95 & 625 & 150 & YKSB97-S-04318 & $0.5-0.7$ & & & ND & ND & 14 \\
\hline Mar 95 & 625 & 150 & YKSB97-S-04319 & 2 & & & ND & ND & 12 \\
\hline Mar 95 & 625 & 175 & YKSB98-S-04320 & $0.5-0.7$ & & & 30 & ND & 12 \\
\hline Mar 95 & 625 & 175 & YKSB98-S-04321 & 2 & & & 16 & ND & 13 \\
\hline Mar 95 & 625 & 200 & YKSB99-S-04322 & $0.5-0.7$ & & & ND & ND & 13 \\
\hline Mar 95 & 625 & 200 & YKSB99-S-04323 & 2 & & & ND & ND & 13 \\
\hline Mar 95 & 640 & 10 & YKSB94-S-04312 & $0.5-0.7$ & & & ND & ND & 12 \\
\hline Mar 95 & 640 & 10 & YKSB94-S-04313 & 1 & & & 24 & ND & 12 \\
\hline Sep 94 & 650 & 5 & YKSS442417V & & 3.07 & 0.51 & & & \\
\hline Oct 94 & 650 & 10 & YKSB84-S-02703 & $0.5-0.7$ & & & ND & ND & 29 \\
\hline Oct 94 & 650 & 10 & YKSB84-S-02704 & $0.7-2$ & & & ND & ND & 24 \\
\hline Oct 94 & 650 & 10 & YKSB84-S-02705 & $2-4$ & & & ND & ND & 21 \\
\hline Mar 95 & 650 & 10 & YKSB93-S-04310 & $0.5-0.7$ & & & 60 & ND & 13 \\
\hline Mar 95 & 650 & 10 & YKSB93-S-04311 & 1 & & & 39 & ND & 14 \\
\hline Sep 94 & 650 & 205 & YKSS392412V & & 0.42 & 0.1 & & & \\
\hline
\end{tabular}


TABLE 2.2 (Cont.)

\begin{tabular}{|c|c|c|c|c|c|c|c|c|c|}
\hline \multirow[b]{4}{*}{ Date } & & & \multirow[b]{4}{*}{ Sample } & \multirow[b]{4}{*}{$\begin{array}{c}\text { Depth } \\
\text { (ft BGL) }\end{array}$} & \multicolumn{5}{|c|}{ Concentration $(\mu \mathrm{g} / \mathrm{kg})$} \\
\hline & & & & & \multicolumn{2}{|c|}{ GC-ECD ${ }^{b}$} & \multicolumn{3}{|c|}{ GC-MS (CLP) ${ }^{\mathrm{C}}$} \\
\hline & \multicolumn{2}{|c|}{ Location $^{\mathrm{a}}$} & & & \multirow[b]{2}{*}{$\begin{array}{c}\text { Carbon } \\
\text { Tetrachloride }\end{array}$} & \multirow[b]{2}{*}{ Chloroform } & \multirow[b]{2}{*}{$\begin{array}{c}\text { Carbon } \\
\text { Tetrachloride }\end{array}$} & \multirow[b]{2}{*}{ Chloroform } & \multirow[b]{2}{*}{$\begin{array}{c}\text { Quantitation } \\
\text { Limit }\end{array}$} \\
\hline & North & West & & & & & & & \\
\hline Sep 94 & 675 & 100 & YKSS602433V & & 0.28 & 0.27 & & & \\
\hline Sep 94 & 675 & 150 & YKSS612434V & & 0.26 & 0.14 & & & \\
\hline Sep 94 & 700 & 5 & YKSS452418V & & 1.06 & 0.43 & & & \\
\hline Sep 94 & 700 & 205 & YKSS402413V & & 0.09 & $<0.04$ & & & \\
\hline Sep 94 & 725 & 100 & YKSS622435V & & 0.39 & $<0.07$ & & & \\
\hline Sep 94 & 725 & 150 & YKSS632436V & & 0.13 & $<0.05$ & & & \\
\hline Sep 94 & 750 & 5 & YKSS462419V & & 0.52 & 0.19 & & & \\
\hline Sep 94 & 750 & 205 & YKSS412414V & & 0.13 & $<0.07$ & & & \\
\hline Sep 94 & 775 & 100 & YKSS642437V & & 0.57 & 0.29 & & & \\
\hline Sep 94 & 775 & 150 & YKSS652438V & & 0.13 & 0.15 & & & \\
\hline Sep 94 & 800 & 5 & YKSS472420V & & 0.12 & $<0.05$ & & & \\
\hline Sep 94 & 800 & 205 & YKSS422415V & & 0.08 & 0.14 & & & \\
\hline Sep 94 & 825 & 100 & YKSS662439V & & 0.14 & $<0.05$ & & & \\
\hline Sep 94 & 825 & 150 & YKSS672440V & & 0.09 & $<0.04$ & & & \\
\hline Sep 94 & 850 & 5 & 5YKSS482421V & & 0.1 & $<0.06$ & & & \\
\hline
\end{tabular}

a Locations are shown as distances in feet from an arbitrary reference point at the southeast corner of the former CCC/USDA facility.

b Samples were collected in September 1994, preserved on dry ice, and analyzed by the headspace method on a GC-ECD system (Argonne 1995b).

c Samples were collected in October 1994 and March 1995, preserved with methanol, and analyzed by the CLP method on a GC-MS system (Argonne 1995b).

d ND, compound analyzed for but not detected at a level greater than or equal to the indicated quantitation limit. 
TABLE 2.3 Organic analysis results for vertical-profile soil samples, 1993.

CPT Holes

\begin{tabular}{|c|c|c|c|c|c|c|c|c|c|c|c|}
\hline I & СРТ 37 & YK37-CPT52-S-01151 & $07 / 27 / 93$ & $1-3$ & 98 & 132 & $\mathrm{ND}^{\mathrm{C}}$ & ND & ND & ND & ND \\
\hline I & СРТ 37 & YK37-CРT52-S-01152 & $07 / 27 / 93$ & $4-6$ & 26 & 35 & ND & ND & ND & ND & ND \\
\hline I & СРТ 37 & YK37-СРТ52-S-01153 & $07 / 27 / 93$ & $7-9$ & 26 & 35 & ND & ND & ND & ND & ND \\
\hline I & СРТ 37 & YK37-СРT52-S-01154 & $07 / 27 / 93$ & $10-12$ & 39 & 42 & ND & ND & ND & ND & ND \\
\hline I & СРТ 37 & YK37-СРТ52-S-01155 & $07 / 27 / 93$ & $13-15$ & 25 & 27 & ND & ND & ND & ND & ND \\
\hline I & СРТ 37 & YK37-CРT52-S-01156 & $07 / 27 / 93$ & $16-18$ & 78 & 42 & ND & ND & ND & ND & ND \\
\hline I & СРТ 37 & YK37-CРT52-S-01157 & $07 / 27 / 93$ & $19-21$ & 84 & 45 & ND & ND & ND & ND & ND \\
\hline I & СРТ 37 & YK37-CРT52-S-01158 & $07 / 27 / 93$ & $22-24$ & 201 & 43 & ND & ND & ND & ND & ND \\
\hline I & СРТ 37 & YK37-CРT52-S-01160 & $07 / 27 / 93$ & $24-24.5$ & 281 & 60 & ND & ND & ND & ND & ND \\
\hline I & СРТ 37 & YK37-CPT52-S-01161 & $07 / 27 / 93$ & $26-28$ & 148 & 32 & ND & ND & ND & ND & ND \\
\hline I & СРТ 37 & YK37-CРT52-S-01162 & $07 / 27 / 93$ & 29-31 & 43 & 23 & ND & ND & ND & ND & ND \\
\hline I & СРТ 37 & YK37-CPT52-S-01163 & $07 / 27 / 93$ & $32-34$ & 70 & 30 & ND & ND & ND & ND & ND \\
\hline I & СРТ 37 & YK37-CРT52-S-01164 & $07 / 27 / 93$ & $35-37$ & 126 & 34 & ND & ND & ND & ND & ND \\
\hline I & СРТ 37 & YK37-CРT52-S-01165 & $07 / 27 / 93$ & $38-40$ & 128 & 43 & ND & ND & ND & ND & ND \\
\hline I & СРТ 37 & YK37-CРT52-S-01166 & $07 / 27 / 93$ & $41-43$ & 57 & 48 & ND & ND & 15 & ND & ND \\
\hline I & СРТ 37 & YK37-CPT52-S-01168 & $07 / 27 / 93$ & $44-45$ & 10 & 22 & ND & ND & ND & ND & ND \\
\hline I & СРТ 37 & YK37-CРT52-S-01167 & $07 / 27 / 93$ & $45-46$ & 37 & 32 & ND & ND & ND & ND & ND \\
\hline I & СРТ 37 & YK37-СРТ52-S-01169 & $07 / 27 / 93$ & $47-48$ & 20 & 34 & ND & ND & ND & ND & ND \\
\hline I & СРТ 37 & YK37-CРT52-S-01170 & $07 / 27 / 93$ & $48-49$ & 67 & 23 & ND & ND & ND & ND & ND \\
\hline I & СРТ 37 & YK37-CPT52-S-01171 & $07 / 27 / 93$ & $50-52$ & ND & 25 & ND & ND & ND & ND & ND \\
\hline I & СРТ 37 & YK37-CРT52-S-01172 & $07 / 27 / 93$ & $53-54$ & ND & 42 & ND & ND & ND & ND & ND \\
\hline I & СРТ 37 & YK37-CРT52-S-01174 & $07 / 27 / 93$ & 54-55 & ND & 17 & ND & ND & ND & ND & ND \\
\hline I & СРТ 37 & YK37-CРT52-S-01175 & $07 / 27 / 93$ & $56.5-57.5$ & ND & 24 & ND & ND & ND & ND & ND \\
\hline I & СРТ 37 & YK37-CРT52-S-01176 & $07 / 27 / 93$ & $59-61$ & ND & 33 & ND & ND & ND & ND & ND \\
\hline I & СРТ 37 & YK37-CРT52-S-01177 & $07 / 27 / 93$ & $62-64$ & ND & 17 & ND & ND & ND & ND & ND \\
\hline I & СРТ 37 & YK37-CPT52-S-01178 & $07 / 27 / 93$ & $65-67$ & ND & 17 & ND & ND & ND & ND & ND \\
\hline I & СРТ 37 & YK37-CРT52-S-01179 & $07 / 27 / 93$ & $68-70$ & ND & 11 & ND & ND & ND & ND & ND \\
\hline i & СРТ 37 & YK37-CPT52-S-01180 & $07 / 27 / 93$ & $85-87$ & 186 & 16 & ND & ND & ND & ND & ND \\
\hline \multicolumn{12}{|c|}{ Auger Boreholes } \\
\hline I & SB 1 & YKSB1-03-S-00950 & 07/08/93 & $0.6-0.9$ & 111 & 38 & ND & ND & ND & ND & ND \\
\hline I & SB 1 & YKSB1-03-S-00951 & 07/08/93 & $2.2-2.5$ & 89 & 24 & ND & ND & ND & ND & ND \\
\hline I & SB 1 & YKSB1-03-S-00953 & 07/08/93 & $2.5-2.8$ & 29 & 16 & ND & ND & ND & ND & ND \\
\hline
\end{tabular}

Concentration $(\mu \mathrm{g} / \mathrm{kg})^{a, b}$

\begin{tabular}{|c|c|c|c|c|c|c|c|c|c|c|c|}
\hline \multirow[b]{2}{*}{ Phase } & \multirow[b]{2}{*}{$\begin{array}{l}\text { Well or } \\
\text { Location }\end{array}$} & \multirow[b]{2}{*}{ Sample } & \multirow[b]{2}{*}{ Date } & \multirow[b]{2}{*}{$\begin{array}{c}\text { Depth } \\
\text { (ft BGL) }\end{array}$} & \multicolumn{7}{|c|}{ Concentration $(\mu \mathrm{g} / \mathrm{kg})^{\mathrm{a}, \mathrm{v}}$} \\
\hline & & & & & CT & $\mathrm{CF}$ & TCE & DCE & TCA & PCE & EB \\
\hline
\end{tabular}


TABLE 2.3 (Cont.)

\begin{tabular}{|c|c|c|c|c|c|c|c|c|c|c|c|}
\hline \multirow[b]{2}{*}{ Phase } & \multirow[b]{2}{*}{$\begin{array}{l}\text { Well or } \\
\text { Location }\end{array}$} & \multirow[b]{2}{*}{ Sample } & \multirow[b]{2}{*}{ Date } & \multirow[b]{2}{*}{$\begin{array}{c}\text { Depth } \\
\text { (ft BGL) }\end{array}$} & \multicolumn{7}{|c|}{ Concentration $(\mu \mathrm{g} / \mathrm{kg})^{\mathrm{a}, \mathrm{b}}$} \\
\hline & & & & & CT & CF & TCE & DCE & TCA & PCE & EB \\
\hline \multicolumn{12}{|c|}{ Auger Boreholes (cont.) } \\
\hline I & SB 1 & YKSB1-03-S-00952 & 07/08/93 & $4.2-4.5$ & 32 & 17 & ND & ND & ND & ND & ND \\
\hline i & SB 1 & YKSB1-03-S-00954 & $07 / 08 / 93$ & $12.6-12.9$ & 73 & 16 & ND & ND & ND & ND & ND \\
\hline i & SB 1 & YKSB1-03-S-00955 & $07 / 08 / 93$ & $17.6-17.9$ & 486 & 42 & ND & ND & ND & ND & ND \\
\hline I & SB 1 & YKSB1-03-S-00956 & 07/08/93 & $19.5-19.7$ & 400 & 32 & ND & ND & ND & ND & ND \\
\hline I & SB 1 & YKSB1-03-S-00957 & 07/08/93 & $20.5-20.8$ & 289 & 37 & ND & ND & ND & ND & ND \\
\hline I & SB 1 & YKSB1-03-S-00958 & 07/08/93 & $24.8-24.9$ & 772 & 42 & ND & ND & ND & ND & ND \\
\hline I & SB 1 & YKSB1-03-S-00960 & 07/08/93 & $25.8-26$ & 522 & 28 & ND & ND & ND & ND & ND \\
\hline I & SB 1 & YKSB1-03-S-00961 & 07/08/93 & $29.8-30$ & 343 & 15 & ND & ND & ND & ND & ND \\
\hline i & SB 1 & YKSB1-03-S-00962 & $07 / 08 / 93$ & $30.5-30.7$ & 370 & 25 & ND & ND & ND & ND & ND \\
\hline I & SB 1 & YKSB1-03-S-00963 & 07/08/93 & $34.5-34.7$ & 299 & 16 & ND & ND & ND & ND & ND \\
\hline I & SB 1 & YKSB1-03-S-00964 & 07/08/93 & $37-37.2$ & 563 & 39 & ND & ND & ND & ND & ND \\
\hline I & SB 1 & YKSB1-03-S-00965 & 07/08/93 & $38.8-39$ & 367 & 32 & ND & ND & ND & ND & ND \\
\hline I & SB 1 & YKSB1-03-S-00966 & 07/08/93 & $41.5-41.7$ & 236 & 26 & ND & ND & ND & ND & ND \\
\hline I & SB 1 & YKSB1-03-S-00967 & 07/08/93 & $39.8-40$ & 443 & 19 & ND & ND & ND & ND & ND \\
\hline I & SB 1 & YKSB1-03-S-00968 & 07/08/93 & $47-47.2$ & 27 & 12 & ND & ND & ND & ND & ND \\
\hline I & SB 1 & YKSB1-03-S-00969 & 07/08/93 & $48-48.2$ & 644 & 55 & ND & ND & ND & ND & ND \\
\hline I & SB 1 & YKSB1-03-S-00970 & 07/08/93 & 49.3-49.6 & 4 & 14 & ND & ND & ND & ND & ND \\
\hline I & SB 1 & YKSB1-03-S-00971 & 07/08/93 & $50.4-50.6$ & 12 & 25 & 6 & ND & ND & ND & ND \\
\hline I & SB 1 & YKSB1-03-S-00972 & 07/08/93 & $51.3-51.5$ & 402 & 55 & 8 & ND & 80 & ND & ND \\
\hline I & SB 1 & YKSB1-03-S-00973 & 07/08/93 & $52.5-52.7$ & 26 & 45 & 11 & ND & 103 & ND & ND \\
\hline I & SB 1 & YKSB1-03-S-00974 & 07/08/93 & $57.5-57.5$ & 12 & 41 & 10 & ND & 74 & ND & ND \\
\hline I & SB 1 & YKSB1-03-S-00977 & 07/08/93 & 61.7-61.9 & 24 & 52 & 12 & ND & 119 & ND & ND \\
\hline i & SB 1 & YKSB1-03-S-00978 & $07 / 08 / 93$ & $66.7-66.9$ & 15 & 17 & ND & ND & ND & ND & ND \\
\hline I & SB 1 & YKSB1-03-S-00979 & 07/08/93 & 71.3-71.4 & 542 & 23 & ND & ND & ND & ND & ND \\
\hline I & SB 36 & YKSB36-02-S-01100 & $07 / 27 / 93$ & $90-92$ & ND & 9 & ND & ND & ND & ND & ND \\
\hline I & SB 36 & YKSB36-02-S-01102 & $07 / 27 / 93$ & 99-101 & ND & 20 & ND & ND & ND & ND & ND \\
\hline I & SB 36 & YKSB36-02-S-01103 & $07 / 27 / 93$ & $104.5-106.5$ & ND & 17 & ND & ND & ND & ND & ND \\
\hline I & SB 36 & YKSB36-02-S-01105 & $07 / 27 / 93$ & 110-110.5 & ND & 7 & ND & ND & ND & ND & ND \\
\hline I & SB 36 & YKSB36-02-S-01106 & 07/27/93 & $110.5-111$ & 5 & 13 & ND & ND & ND & ND & ND \\
\hline I & SB 36 & YKSB36-02-S-01112 & $07 / 27 / 93$ & $128-129$ & & & & & & & \\
\hline II & SB 62 & YKSB6201302 & $11 / 02 / 93$ & $1-1.5$ & & & & & & & \\
\hline II & SB 62 & YKSB6201300 & $11 / 02 / 93$ & $2-2.5$ & ND & ND & & & & & \\
\hline II & SB 62 & YKSB6201301 & $11 / 02 / 93$ & $4-4.5$ & 10 & 34 & & & & & \\
\hline
\end{tabular}


TABLE 2.3 (Cont.)

\begin{tabular}{|c|c|c|c|c|c|c|c|c|c|c|c|}
\hline \multirow[b]{2}{*}{ Phase } & \multirow[b]{2}{*}{$\begin{array}{l}\text { Well or } \\
\text { Location }\end{array}$} & \multirow[b]{2}{*}{ Sample } & \multirow[b]{2}{*}{ Date } & \multirow[b]{2}{*}{$\begin{array}{l}\text { Depth } \\
\text { (ft BGL) }\end{array}$} & \multicolumn{7}{|c|}{ Concentration $(\mu \mathrm{g} / \mathrm{kg})^{\mathrm{a}, \mathrm{b}}$} \\
\hline & & & & & CT & CF & TCE & DCE & TCA & PCE & EB \\
\hline \multicolumn{12}{|c|}{ Auger Boreholes (cont.) } \\
\hline II & SB 62 & YKSB6201304 & $11 / 02 / 93$ & $6-6.5$ & ND & ND & & & & & \\
\hline II & SB 62 & YKSB6201303 & $11 / 02 / 93$ & 8-8.5 & 6 & 42 & & & & & \\
\hline II & SB 62 & YKSB6201305 & $11 / 02 / 93$ & 10.3-10.6 & ND & ND & & & & & \\
\hline II & SB 62 & YKSB6201306 & $11 / 02 / 93$ & $23-23.5$ & 6 & 30 & & & & & \\
\hline II & SB 62 & YKSB6201307 & $11 / 02 / 93$ & $26-26.5$ & 8 & 26 & & & & & \\
\hline II & SB 62 & YKSB6201308 & $11 / 02 / 93$ & $29-29.5$ & 25 & 28 & & & & & \\
\hline II & SB 62 & YKSB6201309 & $11 / 02 / 93$ & $31.7-32$ & 22 & 30 & & & & & \\
\hline II & SB 62 & YKSB6201310 & $11 / 02 / 93$ & $38-38.6$ & 46 & 31 & & & & & \\
\hline II & SB 62 & YKSB6201311 & $11 / 02 / 93$ & $40.5-41$ & 49 & 33 & & & & & \\
\hline II & SB 62 & YKSB6201312 & $11 / 02 / 93$ & $46.5-47$ & 31 & 8 & & & & & \\
\hline II & SB 62 & YKSB6201313 & $11 / 02 / 93$ & $48-48.5$ & 3 & 6 & & & & & \\
\hline II & SB 62 & YKSB6201314 & $11 / 02 / 93$ & $51.6-52$ & ND & ND & & & & & \\
\hline II & SB 63 & YKSB6301325 & $11 / 07 / 93$ & 80.3-81 & 10 & 3 & & & & & \\
\hline II & SB 63 & YKSB6301324 & $11 / 07 / 93$ & $81-81.5$ & ND & ND & & & & & \\
\hline II & SB 63 & YKSB6301326 & $11 / 07 / 93$ & $85.5-86$ & ND & ND & & & & & \\
\hline II & SB 63 & YKSB6301328 & $11 / 07 / 93$ & $102-102.5$ & ND & ND & & & & & \\
\hline II & SB 63 & YKSB6301362 & $11 / 08 / 93$ & 120.8 & 3 & ND & & & & & \\
\hline II & SB 67 & YKSB6701366 & $11 / 09 / 93$ & $1.5-2$ & ND & ND & & & & & \\
\hline II & SB 67 & YKSB6701367 & $11 / 09 / 93$ & $3-3.5$ & ND & ND & & & & & \\
\hline II & SB 67 & YKSB6701364 & $11 / 09 / 93$ & $6-6.5$ & ND & ND & & & & & \\
\hline II & SB 67 & YKSB6701365 & $11 / 09 / 93$ & 8-8.5 & ND & ND & & & & & \\
\hline II & SB 67 & YKSB6701368 & $11 / 09 / 93$ & $11.5-12$ & ND & ND & & & & & \\
\hline II & SB 67 & YKSB6701369 & $11 / 09 / 93$ & $14-14.5$ & ND & ND & & & & & \\
\hline II & SB 67 & YKSB6701377 & $11 / 10 / 93$ & $126.5-127$ & ND & ND & & & & & \\
\hline II & SB 67 & YKSB6701378 & $11 / 10 / 93$ & $129-129.5$ & ND & ND & & & & & \\
\hline II & SB 70 & YKSB7001387 & $11 / 13 / 93$ & $151-151.5$ & ND & ND & & & & & \\
\hline II & SB 70 & YKSB7001388 & $11 / 13 / 93$ & $152-152.5$ & ND & ND & & & & & \\
\hline
\end{tabular}

See next page for footnotes. 
a Results are for samples preserved with methanol (Argonne 1994, 1995a).

b Compound codes: CT, carbon tetrachloride; CF, chloroform; TCE, trichloroethylene; DCE, 1,1-dichloroethylene; TCA, trichloroethane; PCE, tetrachloroethylene; EB, ethylene bromide.

c ND, not detected. 
TABLE 2.4 Organic analysis results for groundwater samples, 1993.

\begin{tabular}{|c|c|c|c|c|c|c|c|c|c|c|c|}
\hline \multirow[b]{2}{*}{ Phase } & \multirow[b]{2}{*}{ Well/Location } & \multirow[b]{2}{*}{ Sample } & \multirow[b]{2}{*}{ Date } & \multirow{2}{*}{$\begin{array}{c}\text { Depth } \\
\text { (ft BGL) }\end{array}$} & \multicolumn{7}{|c|}{ Concentration $(\mu \mathrm{g} / \mathrm{L})^{\mathrm{a}}$} \\
\hline & & & & & CT & CF & TCE & DCE & TCA & PCE & EB \\
\hline \multicolumn{12}{|c|}{ Public Water Supply Wells ${ }^{b}$} \\
\hline I & PWS 48-1 ${ }^{c}$ & YKPW08W-01077 & $7 / 28 / 93$ & $100-135$ & $\mathrm{ND}^{\mathrm{d}}$ & ND & 1 & ND & ND & ND & ND \\
\hline I & PWS $62-1^{c}$ & YKPW12W-01024 & $7 / 28 / 93$ & 183 & ND & ND & ND & ND & ND & ND & ND \\
\hline I & PWS $68-1^{c}$ & YKPW05W-01074 & $7 / 19 / 93$ & 356 & ND & ND & ND & ND & ND & ND & ND \\
\hline I & PWS $73-1^{c}$ & YKPW06W-01075 & $7 / 19 / 93$ & 159-394 & ND & ND & ND & ND & ND & ND & ND \\
\hline I & PWS 76-1 & YKPW11W-01023 & $7 / 19 / 93$ & $125-195$ & ND & ND & ND & ND & ND & ND & ND \\
\hline I & PWS 77-1 ${ }^{c}$ & YKPW04W-01073 & $7 / 19 / 93$ & $183-380$ & ND & ND & 1 & ND & ND & ND & ND \\
\hline I & PWS $77-3^{c}$ & YKPW13W-01025 & $7 / 28 / 93$ & $157.5-292$ & ND & ND & ND & ND & ND & ND & ND \\
\hline I & PWS 77-4c & YKPW10W-01079 & $7 / 28 / 93$ & $140.5-249$ & ND & ND & ND & ND & ND & ND & ND \\
\hline I & PWS 81-1 ${ }^{c}$ & YKPW01W-01070 & $7 / 19 / 93$ & 145-385 & 1 & ND & 25 & 5 & 6 & 3 & ND \\
\hline I & PWS 82-1c & YKPW02W-01071 & $7 / 19 / 93$ & $173.5-368.5$ & ND & ND & ND & ND & ND & ND & ND \\
\hline I & PWS 82-2c & YKPW03W-01072 & $7 / 19 / 93$ & $170-340$ & ND & ND & ND & ND & ND & ND & ND \\
\hline \multicolumn{12}{|c|}{ Private Wells } \\
\hline I & Preslika & YKDW19W00985 & $7 / 12 / 93$ & & 2 & ND & ND & ND & ND & ND & ND \\
\hline i & Krocker residence & YKDW21W00988 & $7 / 14 / 93$ & & ND & ND & 1 & ND & 1 & 1 & ND \\
\hline I & Y Motel & YKDW22W01010 & $7 / 14 / 93$ & & ND & ND & ND & ND & ND & ND & ND \\
\hline I & Welsh Implements & YKDW23W01012 & $7 / 14 / 93$ & & 1 & ND & ND & ND & ND & ND & ND \\
\hline I & Cotner residence & YKDW26A00984 & $7 / 12 / 93$ & & 49 & ND & ND & ND & ND & ND & ND \\
\hline I & Wize residence & YKDW26B00983 & $7 / 12 / 93$ & & 16 & ND & ND & ND & ND & ND & ND \\
\hline i & Batterton CLM Rental & YKDW28W01013 & $7 / 14 / 93$ & & 40 & ND & ND & ND & ND & ND & ND \\
\hline i & Sachs, Omega, irrigation & YKDW33AW-01034 & $7 / 26 / 93$ & & ND & ND & ND & 1 & 3 & 3 & ND \\
\hline i & Maken Equipment & YKDW34W00987 & $7 / 12 / 93$ & & 1 & ND & ND & ND & 7 & 2 & ND \\
\hline I & Staehr Motel & YKDW35W00986 & $7 / 12 / 93$ & & 1 & ND & ND & ND & ND & ND & ND \\
\hline I & Dale A. Olson domestic & YKDW37-W-01000 & $7 / 10 / 93$ & & 8 & ND & ND & ND & ND & ND & ND \\
\hline I & Oloen residence & YKDW37W-01125 & $7 / 28 / 93$ & & 6 & ND & ND & ND & ND & ND & ND \\
\hline I & York County Shops & YKDW38-W-01001 & $7 / 10 / 93$ & & ND & ND & ND & ND & ND & ND & ND \\
\hline i & Nordlund residence & YKDW39W01006 & $7 / 16 / 93$ & & ND & ND & ND & ND & ND & ND & ND \\
\hline I & Euchner residence & YKDW40W01005 & $7 / 16 / 93$ & & ND & ND & 79 & 1 & ND & 1 & ND \\
\hline i & Robinson residence & YKDW41W01007 & $7 / 16 / 93$ & & 10 & ND & 199 & 10 & 13 & 6 & ND \\
\hline I & Klone residence & YKDW42W01020 & $7 / 16 / 93$ & & 6 & ND & 158 & 6 & 10 & 5 & ND \\
\hline I & Potter residence & YKDW43W01009 & $7 / 16 / 93$ & & 1 & ND & 79 & 2 & 2 & 1 & ND \\
\hline I & Troutman residence & YKDE44W01008 & $7 / 16 / 93$ & & 2 & ND & 40 & 3 & 6 & 2 & ND \\
\hline I & White residence & YKDW46W01014 & $7 / 16 / 93$ & & ND & ND & ND & ND & ND & ND & ND \\
\hline
\end{tabular}
PWS 73-1c
PWS 77-3c
PWS 82-1
PWS 82-2

Preslika

Y Motel

Implements

rigation

domestic

Robinson residence

White residence 
TABLE 2.4 (Cont.)

\begin{tabular}{|c|c|c|c|c|c|c|c|c|c|c|c|}
\hline \multirow[b]{2}{*}{ Phase } & \multirow[b]{2}{*}{ Well/Location } & \multirow[b]{2}{*}{ Sample } & \multirow[b]{2}{*}{ Date } & \multirow{2}{*}{$\begin{array}{l}\text { Depth } \\
\text { (ft BGL) }\end{array}$} & \multicolumn{7}{|c|}{ Concentration $(\mu \mathrm{g} / \mathrm{L})^{\mathrm{a}}$} \\
\hline & & & & & CT & CF & TCE & DCE & TCA & PCE & EB \\
\hline
\end{tabular}

Private Wells (cont.)

$\begin{array}{lll}\text { Larkin residence } & \text { YKDW47W01015 } & 7 / 16 / 93 \\ \text { Hurlbut residence } & \text { YKDW48W01016 } & 7 / 16 / 93 \\ \text { McCotchey residence } & \text { YKDW49W01017 } & 7 / 16 / 93 \\ \text { Fassig residence } & \text { YKDW50W01003 } & 7 / 16 / 93 \\ \text { Peeks residence } & \text { YKDW51W01002 } & 7 / 16 / 93 \\ \text { Blankenship residence } & \text { YKDW52W01019 } & 7 / 16 / 93 \\ \text { Brokinicky residence } & \text { YKDW53W01018 } & 7 / 16 / 93 \\ \text { Callahan residence } & \text { YKDW54W01021 } & 7 / 16 / 93 \\ \text { Lierman House } & \text { YKDW55W00989 } & 7 / 14 / 93 \\ \text { Blue Valley Comm Center } & \text { YKDW56W01011 } & 7 / 14 / 93 \\ \text { Nygren Rental } & \text { YKDW60W-01126 } & 7 / 28 / 93 \\ \text { Blankenship residence } & \text { YKDW61W-01127 } & 7 / 28 / 93 \\ \text { Duplicate } & \text { YKDW61W-01128 } & 7 / 28 / 93\end{array}$

$\begin{array}{rrrrrrr}\text { ND } & \text { ND } & 32 & \text { ND } & \text { ND } & \text { ND } & \text { ND } \\ \text { ND } & \text { ND } & 100 & \text { ND } & \text { ND } & 1 & \text { ND } \\ \text { ND } & \text { ND } & 32 & \text { ND } & 1 & 1 & \text { ND } \\ \text { ND } & \text { ND } & 79 & 1 & 1 & 1 & \text { ND } \\ \text { ND } & \text { ND } & 32 & 1 & 1 & 1 & \text { ND } \\ \text { ND } & \text { ND } & 63 & 1 & \text { ND } & \text { ND } & \text { ND } \\ \text { ND } & \text { ND } & 79 & \text { ND } & \text { ND } & 1 & \text { ND } \\ \text { ND } & \text { ND } & 1 & \text { ND } & \text { ND } & \text { ND } & \text { ND } \\ \text { ND } & \text { ND } & \text { ND } & \text { ND } & \text { ND } & \text { ND } & \text { ND } \\ \text { ND } & \text { ND } & \text { ND } & \text { ND } & \text { ND } & \text { ND } & \text { ND } \\ 2 & \text { ND } & 1 & 3 & 13 & 5 & \text { ND } \\ \text { ND } & \text { ND } & \text { ND } & \text { ND } & \text { ND } & \text { ND } & \text { ND } \\ \text { ND } & \text { ND } & \text { ND } & \text { ND } & \text { ND } & \text { ND } & \text { ND }\end{array}$

Irrigation Wells

Sachs irrigation
Sachs irrigation
Sachs irrigation
Fassig irrigation

\section{CPT Holes}

$\begin{array}{ll}\text { II } & \text { CPT1A } \\ \text { II } & \text { CPT1A } \\ \text { II } & \text { CPT1A } \\ \text { I } & \text { CPT } 3 \\ \text { I } & \text { CPT } 3 \\ \text { I } & \text { CPT } 5 \\ \text { II } & \text { CPT } 5 \\ \text { II } & \text { CPT } 5\end{array}$

YKIW01W-01130 7/29/93

YKIW01W-01131 7/29/93

YKIW01W-01132 7/29/93

YKIW77W-01004 7/16/93

YKSB01A01351

YKSB01A01352

YKSB01A01353

YK03CРT018W-01045

YK03CРT019W-01046

YK05CPT017W-01044

YKSB501354

YKSB501355

$\begin{array}{lcrrrrrrr}11 / 13 / 93 & 77-79.5 & 315 & 13 & \text { ND } & \text { ND } & \text { ND } & \text { ND } & \text { ND } \\ 11 / 13 / 93 & 92-93.5 & 20 & 2 & \text { ND } & \text { ND } & \text { ND } & \text { ND } & \text { ND } \\ 11 / 13 / 93 & 109-110 & 1 & \text { ND } & \text { ND } & \text { ND } & \text { ND } & \text { ND } & \text { ND } \\ & & & & & & & & \\ 7 / 17 / 93 & 75-77 & 397 & 4 & \text { ND } & 1 & \text { ND } & \text { ND } & \text { ND } \\ 7 / 174 / 93 & 87-90 & 1990 & 20 & \text { ND } & 1 & \text { ND } & \text { ND } & \text { ND } \\ & & & & & & & & \\ 7 / 17 / 93 & 75-77 & 5 & \text { ND } & \text { ND } & \text { ND } & \text { ND } & \text { ND } & \text { ND } \\ 11 / 14 / 93 & 89.7-91.2 & 4 & \text { ND } & \text { ND } & \text { ND } & \text { ND } & \text { ND } & 2 \\ 11 / 14 / 93 & 115.5-116.5 & \text { ND } & \text { ND } & \text { ND } & \text { ND } & \text { ND } & \text { ND } & 2\end{array}$




\begin{tabular}{|c|c|c|c|c|c|c|c|c|c|c|c|}
\hline \multirow[b]{2}{*}{ Phase } & \multirow[b]{2}{*}{ Well/Location } & \multirow[b]{2}{*}{ Sample } & \multirow[b]{2}{*}{ Date } & \multirow{2}{*}{$\begin{array}{l}\text { Depth } \\
\text { (ft BGL) }\end{array}$} & \multicolumn{7}{|c|}{ Concentration $(\mu \mathrm{g} / \mathrm{L})^{\mathrm{a}}$} \\
\hline & & & & & CT & $\mathrm{CF}$ & TCE & DCE & TCA & PCE & $\mathrm{EB}$ \\
\hline \multicolumn{12}{|c|}{ CPT Holes (cont.) } \\
\hline 1 & СРT 6 & YК06СРТ008-W-00993 & $7 / 10 / 93$ & 82-84 & 1 & ND & ND & ND & ND & ND & ND \\
\hline I & СРТ 6 & YK06CРT008-W-00994 & $7 / 10 / 93$ & $102.5-103$ & ND & ND & ND & ND & ND & ND & ND \\
\hline II & СРТ 6 & YKSB601407 & $11 / 17 / 93$ & $118.2-119.8$ & 2 & ND & ND & ND & ND & ND & ND \\
\hline I & СРТ 7 & YК07СРТ011-00995 & 7/10/93 & $78-80$ & 25 & 2 & ND & ND & ND & ND & ND \\
\hline I & СРT 7 & YK07CРТ008-W-00992 & 7/9/93 & $89.5-90$ & 10 & 1 & ND & ND & ND & ND & ND \\
\hline I & CРT 8 & YK08СРT026W-01048 & 7/17/93 & $76-79$ & 100 & 2 & ND & 1 & ND & ND & ND \\
\hline I & СРТ 8 & YK08CPT025W-01047 & 7/17/93 & $105-108$ & 10 & ND & ND & ND & ND & ND & ND \\
\hline I & СРТ 9 & YK09СРТ027W-01049 & 7/18/93 & $76-79$ & ND & ND & ND & ND & ND & ND & ND \\
\hline I & СРТ 9 & YK09CPT007-W-00991 & 7/9/93 & $89.5-90$ & 4 & ND & ND & ND & ND & ND & ND \\
\hline 1 & СРT 11 & YK11CPT016W-01043 & $7 / 16 / 93$ & 81-84 & ND & ND & ND & ND & ND & 1 & ND \\
\hline I & CPT 13 & YK13CPT47W-01089 & $7 / 24 / 93$ & $78-81$ & ND & ND & ND & 1 & ND & ND & ND \\
\hline 1 & CPT 13 & YK13CPT46W-01088 & $7 / 24 / 93$ & $93-96$ & 1 & ND & 1 & 3 & 10 & 4 & ND \\
\hline 1 & СРT 17 & YK17CPT004-W-00990 & $7 / 8 / 93$ & $88.7-89.7$ & ND & ND & ND & ND & ND & ND & ND \\
\hline I & СРT 21 & YK21CPT43W-01085 & $7 / 23 / 93$ & $87-90$ & 3 & ND & 16 & 3 & 3 & 2 & ND \\
\hline i & CPT 21 & YK21CPT41W-01084 & $7 / 23 / 93$ & $94-97$ & 13 & ND & 79 & 10 & 20 & 10 & ND \\
\hline I & CPT 24 & YK24CPT014W-01041 & 7/16/93 & $77-79$ & ND & ND & ND & 1 & ND & ND & ND \\
\hline I & CPT 24 & YK24CPT30W-01053 & 7/19/93 & 96-99 & ND & ND & ND & $\mathrm{ND}$ & ND & ND & ND \\
\hline I & CPT 24 & YK24CPT50W-01092 & $7 / 26 / 93$ & $122.5-124$ & ND & ND & ND & ND & ND & ND & ND \\
\hline I & CPT 25 & YK25CPT40W-01083 & 7/23/93 & $76-79$ & 13 & ND & 25 & 6 & 13 & 4 & ND \\
\hline 1 & CPT 25 & YK25CРT39W-01082 & $7 / 22 / 93$ & $90-93$ & ND & ND & 6 & ND & ND & ND & ND \\
\hline I & CPT 26 & YK26CPT015W-01042 & $7 / 16 / 93$ & $83-86$ & ND & ND & 1 & 1 & ND & ND & ND \\
\hline 1 & CPT 27 & YK27CРT013-00997 & $7 / 11 / 93$ & 81-81 & ND & ND & ND & ND & ND & ND & ND \\
\hline
\end{tabular}




\begin{tabular}{|c|c|c|c|c|c|c|c|c|c|c|c|}
\hline \multirow[b]{2}{*}{ Phase } & \multirow[b]{2}{*}{ Well/Location } & \multirow[b]{2}{*}{ Sample } & \multirow[b]{2}{*}{ Date } & \multirow{2}{*}{$\begin{array}{c}\text { Depth } \\
\text { (ft BGL) }\end{array}$} & \multicolumn{7}{|c|}{ Concentration $(\mu \mathrm{g} / \mathrm{L})^{\mathrm{a}}$} \\
\hline & & & & & CT & CF & TCE & DCE & TCA & PCE & $E B$ \\
\hline \multicolumn{12}{|c|}{ CPT Holes (cont.) } \\
\hline I & СРТ 28 & YK28СРТ012-00996 & $7 / 10 / 93$ & 84-86 & 1 & ND & ND & ND & ND & ND & ND \\
\hline II & СРТ28 & YKSB2801344 & $11 / 12 / 93$ & 107-108 & 1 & 2 & ND & ND & ND & ND & 1 \\
\hline II & СРТ28 & YKSB2801345 & $11 / 12 / 93$ & $121.5-122.5$ & 13 & 2 & ND & ND & ND & ND & ND \\
\hline I & СРТ 30 & YK30СРТ031W-01054 & $7 / 19 / 93$ & $74-77$ & ND & ND & ND & ND & ND & ND & ND \\
\hline I & СРТ 30 & YK30СРТ032W-01055 & $7 / 19 / 93$ & $96-99$ & ND & ND & ND & ND & ND & ND & ND \\
\hline I & СРТ 31 & YK31CРТ45W-01087 & $7 / 24 / 93$ & $76-79$ & ND & ND & ND & ND & ND & ND & ND \\
\hline I & СРТ 31 & YK31CРТ44W-01086 & $7 / 24 / 93$ & $99-102$ & ND & ND & ND & ND & ND & ND & ND \\
\hline I & СРТ 32 & YK32CРT34W-01058 & $7 / 21 / 93$ & $74.5-76.5$ & ND & ND & ND & ND & ND & ND & ND \\
\hline I & СРТ 32 & YK32CРТ33W-01057 & $7 / 21 / 93$ & $99-102$ & 3 & ND & ND & ND & ND & ND & ND \\
\hline I & СРТ 33 & YК33СРТ36W-01060 & $7 / 21 / 93$ & 75-76 & ND & ND & ND & ND & ND & ND & ND \\
\hline I & СРТ 33 & YК33СРТ35-01059 & $7 / 21 / 93$ & $98.6-102$ & ND & ND & ND & ND & ND & ND & ND \\
\hline I & СРТ 34 & YK34СРТ38W-01081 & $7 / 22 / 93$ & $90-93$ & ND & ND & ND & ND & ND & ND & ND \\
\hline I & СРТ 35 & YK35CPT49W-01091 & $7 / 26 / 93$ & $79-81.5$ & ND & ND & ND & ND & ND & ND & ND \\
\hline I & СРТ 35 & YK35СРТ48W-01090 & $7 / 26 / 93$ & $99.5-102$ & ND & ND & ND & ND & ND & ND & ND \\
\hline I & СРТ 40 & YK40CРT55W-01095 & $7 / 29 / 93$ & $118-119$ & 1 & ND & ND & ND & ND & ND & ND \\
\hline I & СРТ 40 & YK40CPT54W-01094 & $7 / 29 / 93$ & $119-120$ & 1 & ND & ND & ND & ND & ND & ND \\
\hline I & СРТ 40 & YK40CРT53W-01093 & $7 / 29 / 93$ & $122-124$ & 1 & ND & ND & ND & ND & ND & ND \\
\hline II & СРТ 64 & YKSB6401330 & $11 / 7 / 93$ & $72.5-74$ & 125 & 5 & ND & ND & ND & ND & ND \\
\hline II & СРТ 64 & YKSB6401331 & $11 / 7 / 93$ & $90-91$ & 1577 & 20 & ND & ND & ND & ND & ND \\
\hline II & СРТ 64 & YKSB6401332 & $11 / 7 / 93$ & $98-99$ & 100 & 2 & ND & ND & ND & ND & ND \\
\hline II & СРТ 64 & YKSB6401333 & $11 / 8 / 93$ & $112-113$ & 63 & 1 & ND & ND & ND & ND & ND \\
\hline II & СРТ 64 & YKSB6401334 & $11 / 8 / 93$ & $117-118$ & 79 & 4 & ND & ND & ND & ND & 1 \\
\hline
\end{tabular}




\begin{tabular}{|c|c|c|c|c|c|c|c|c|c|c|c|}
\hline \multirow[b]{2}{*}{ Phase } & \multirow[b]{2}{*}{ Well/Location } & \multirow[b]{2}{*}{ Sample } & \multirow[b]{2}{*}{ Date } & \multirow[b]{2}{*}{$\begin{array}{l}\text { Depth } \\
\text { (ft BGL) }\end{array}$} & \multicolumn{7}{|c|}{ Concentration $(\mu \mathrm{g} / \mathrm{L})^{\mathrm{a}}$} \\
\hline & & & & & CT & CF & TCE & DCE & TCA & PCE & EB \\
\hline \multicolumn{12}{|c|}{ CPT Holes (cont.) } \\
\hline II & СРТ 68 & YKSB6801337 & $11 / 9 / 93$ & $73.5-76$ & 40 & 2 & ND & ND & ND & ND & ND \\
\hline II & СРТ 68 & YKSB6801338 & $11 / 9 / 93$ & $89.5-91$ & 79 & 1 & ND & ND & ND & ND & ND \\
\hline II & СРТ 68 & YKSB6801339 & $11 / 9 / 93$ & 97-99 & 4 & ND & ND & ND & ND & ND & ND \\
\hline II & СРТ 68 & YKSB6801340 & $11 / 9 / 93$ & $119.5-120$ & 2 & ND & ND & ND & ND & ND & ND \\
\hline II & СРТ 69 & YKSB6901341 & $11 / 10 / 93$ & 75-76 & 6 & 1 & ND & ND & ND & 1 & 3 \\
\hline II & СРТ 69 & YKSB6901342 & $11 / 11 / 93$ & $91.7-92.7$ & 158 & 4 & ND & ND & ND & ND & 1 \\
\hline II & СРТ 69 & YKSB6901343 & $11 / 11 / 93$ & $120-123$ & 79 & 3 & ND & ND & ND & ND & 1 \\
\hline II & СРТ 71 & YKSB7101358 & $11 / 15 / 93$ & $75.4-76.9$ & ND & ND & ND & ND & ND & ND & ND \\
\hline II & СРТ 71 & YKSB7101359 & $11 / 15 / 93$ & 87.8-89.8 & ND & ND & ND & ND & ND & ND & ND \\
\hline II & СРТ 71 & YKSB7101400 & $11 / 15 / 93$ & $111-113$ & ND & ND & ND & ND & ND & ND & ND \\
\hline II & СРT 71 & YKSB7101401 & $11 / 15 / 93$ & $143-146$ & ND & ND & ND & ND & ND & ND & ND \\
\hline II & CPT 72 & YKSB7201402 & $11 / 15 / 93$ & $104.3-106.3$ & ND & ND & ND & ND & ND & ND & ND \\
\hline II & СРТ 72 & YKSB7201403 & $11 / 15 / 93$ & $114.2-116.2$ & 3 & ND & ND & ND & ND & ND & ND \\
\hline II & СРТ 72 & YKSB7201404 & $11 / 16 / 93$ & 129.8-131.8 & 2 & ND & ND & ND & ND & ND & ND \\
\hline II & СРТ 73 & YKSB7301405 & $11 / 16 / 93$ & 100.8-102.8 & 2 & 1 & ND & ND & ND & ND & ND \\
\hline II & СРТ 74 & YKSB7401406 & $11 / 16 / 93$ & 113.3-115.3 & 2 & ND & ND & ND & ND & ND & ND \\
\hline \multicolumn{12}{|c|}{ Auger Boreholes } \\
\hline 1 & SB 1 & YKSB1-03-W-00980 & $7 / 8 / 93$ & 77 & 1566 & 32 & ND & ND & ND & ND & ND \\
\hline i & SB 1 & YKSB1-03-W-00981 & $7 / 9 / 93$ & 92 & 78 & 5 & ND & ND & ND & 4 & 1 \\
\hline i & SB 1 & YKSB1-03-W-00982 & $7 / 9 / 93$ & 109 & 2 & ND & ND & ND & ND & ND & ND \\
\hline 1 & SB 29 & YKSB2901W-01063 & 7/16/93 & 92 & 1 & ND & 2 & 1 & 1 & ND & ND \\
\hline i & SB 29 & YKSB2902W-01064 & $7 / 16 / 93$ & 98 & ND & ND & 1 & ND & 1 & 1 & ND \\
\hline i & SB 29 & YKSB2903W-01065 & $7 / 17 / 93$ & 103 & ND & ND & 3 & 1 & ND & ND & ND \\
\hline I & SB 29 & YKSB2904W-01067 & 7/17/93 & 113 & ND & ND & 20 & 1 & ND & ND & ND \\
\hline i & SB 29 & YKSB2905W-01068 & $7 / 17 / 93$ & 117 & ND & ND & 32 & 1 & ND & ND & ND \\
\hline I & SB 29 & YKSB2906W-01069 & 7/17/93 & 123 & ND & ND & 2 & 1 & 1 & ND & ND \\
\hline i & SB 29 & YKSB2907W-01030 & $7 / 17 / 93$ & 127 & ND & ND & ND & ND & ND & ND & ND \\
\hline
\end{tabular}

3

$11 / 15 / 93$

ND

YKSB7101400

YKSB7201402

作SB7201402

YKSB7301405

YKSB7401406

YKSB1-03-W-00980

YKSB1-03-W-00981

$7 / 9 / 93$ 
TABLE 2.4 (Cont.)

\begin{tabular}{|c|c|c|c|c|c|c|c|c|c|c|c|}
\hline \multirow[b]{2}{*}{ Phase } & \multirow[b]{2}{*}{ Well/Location } & \multirow[b]{2}{*}{ Sample } & \multirow[b]{2}{*}{ Date } & \multirow[b]{2}{*}{$\begin{array}{c}\text { Depth } \\
\text { (ft BGL) }\end{array}$} & \multicolumn{7}{|c|}{ Concentration $(\mu \mathrm{g} / \mathrm{L})^{\mathrm{a}}$} \\
\hline & & & & & CT & CF & TCE & DCE & TCA & PCE & $E B$ \\
\hline \multicolumn{12}{|c|}{ Auger Boreholes (cont.) } \\
\hline I & SB 29 & YKSB2908W-01031 & $7 / 17 / 93$ & 132 & ND & ND & 2 & 1 & 2 & ND & ND \\
\hline I & SB 29 & YKSB2909W-01032 & $7 / 18 / 93$ & 142 & ND & ND & 6 & ND & ND & ND & ND \\
\hline I & SB 36 & YKSB3601W-01035 & $7 / 27 / 93$ & $88-89$ & 25 & 2 & ND & ND & ND & ND & ND \\
\hline i & SB 36 & YKSB3603W-01101 & $7 / 27 / 93$ & 98-99 & 13 & 3 & ND & ND & ND & ND & ND \\
\hline I & SB 36 & YKSB3606W-01104 & $7 / 27 / 93$ & 108-109 & 8 & 2 & ND & ND & ND & ND & ND \\
\hline I & SB 36 & YKSB3609W-01107 & $7 / 27 / 93$ & $113-114$ & ND & ND & ND & ND & ND & ND & \\
\hline I & SB 36 & YKSB3610W-01108 & $7 / 27 / 93$ & $118-119$ & 251 & 10 & ND & ND & ND & ND & \\
\hline 1 & SB 36 & YKSB3611W-01111 & $7 / 27 / 93$ & $123-124$ & 2 & 3 & ND & ND & ND & ND & ND \\
\hline II & SB62 & YKSB6201316 & $11 / 2 / 93$ & 73-74 & 1986 & 31 & ND & ND & ND & 1 & ND \\
\hline II & SB62 & YKSB6201318 & $11 / 3 / 93$ & 90.5-91.5 & 31 & 1 & ND & ND & ND & 1 & 4 \\
\hline II & SB62 & YKSB6201319 & $11 / 4 / 93$ & $113.5-114.5$ & 63 & 16 & ND & ND & 1 & ND & ND \\
\hline II & SB62 & YKSB6201320 & $11 / 4 / 93$ & $118.5-119.5$ & 20 & 5 & ND & ND & ND & ND & 2 \\
\hline II & SB63 & YKSB6301322 & $11 / 6 / 93$ & $76-77$ & 158 & 16 & ND & 1 & 16 & 6 & 13 \\
\hline II & SB63 & YKSB6301327 & $11 / 7 / 93$ & $92.5-93.5$ & ND & ND & ND & ND & ND & ND & ND \\
\hline II & SB63 & YKSB6301360 & $11 / 7 / 93$ & $111.5-112.5$ & 10 & 1 & ND & 1 & ND & ND & 1 \\
\hline II & SB63 & YKSB301361 & $11 / 8 / 93$ & $121.5-122.5$ & 10 & 1 & ND & ND & ND & ND & ND \\
\hline II & SB67 & YKSB6701371 & $11 / 9 / 93$ & 81.5 & ND & ND & ND & ND & ND & ND & ND \\
\hline II & SB67 & YKSB6701373 & $11 / 9 / 93$ & $91-92$ & ND & ND & ND & ND & ND & ND & ND \\
\hline II & SB67 & YKSB6701374 & $11 / 10 / 93$ & $101-102$ & ND & ND & ND & ND & ND & ND & ND \\
\hline II & SB67 & YKSB6701375 & $11 / 10 / 93$ & $116-117$ & ND & ND & ND & ND & ND & ND & ND \\
\hline II & SB67 & YKSB6701376 & $11 / 10 / 93$ & $122-123$ & ND & ND & ND & ND & ND & ND & ND \\
\hline II & SB70 & YKSB7001380 & $11 / 12 / 93$ & $77.6-78.5$ & 1 & ND & ND & ND & ND & ND & 1 \\
\hline II & SB70 & YKSB7001381 & $11 / 12 / 93$ & $92-93$ & 2 & ND & ND & ND & ND & ND & ND \\
\hline II & SB70 & YKSB7001382 & $11 / 12 / 93$ & $102-103$ & 20 & ND & ND & ND & ND & ND & ND \\
\hline
\end{tabular}

YKSB7001382

$11 / 12 / 93$

112113 
TABLE 2.4 (Cont.)

\begin{tabular}{|c|c|c|c|c|c|c|c|c|c|c|c|}
\hline \multirow[b]{2}{*}{ Phase } & \multirow[b]{2}{*}{ Well/Location } & \multirow[b]{2}{*}{ Sample } & \multirow[b]{2}{*}{ Date } & \multirow[b]{2}{*}{$\begin{array}{l}\text { Depth } \\
\text { (ft BGL) }\end{array}$} & \multicolumn{7}{|c|}{ Concentration $(\mu \mathrm{g} / \mathrm{L})^{\mathrm{a}}$} \\
\hline & & & & & CT & CF & TCE & DCE & TCA & PCE & EB \\
\hline \multicolumn{12}{|c|}{ Auger Boreholes (cont.) } \\
\hline II & SB70 & YKSB7001384 & $11 / 13 / 93$ & $121-122$ & 40 & ND & ND & ND & ND & ND & ND \\
\hline II & SB70 & YKSB7001385 & $11 / 13 / 93$ & $131-132$ & 20 & 1 & ND & ND & ND & ND & ND \\
\hline II & SB70 & YKSB7001386 & $11 / 13 / 93$ & $141-142$ & 16 & 1 & ND & ND & ND & ND & ND \\
\hline
\end{tabular}

a Compound codes: CT, carbon tetrachloride; CF, chloroform; TCE, trichloroethylene; DCE, 1,1-dichloroethylene; TCA, trichloroethane; PCE, tetrachloroethylene; EB, ethylene bromide.

b Construction logs/registrations are in Phase I Work Plan (Argonne 1993).

c Well has multiple screened intervals.

d ND, not detected 
TABLE 2.5 Analytical results for VOCs in groundwater samples collected from private wells, 2013-2015.

\begin{tabular}{|c|c|c|c|c|c|c|c|}
\hline \multirow[b]{2}{*}{ Location } & \multirow[b]{2}{*}{ Sample } & \multirow[b]{2}{*}{$\begin{array}{c}\text { Sample } \\
\text { Date }\end{array}$} & \multirow[b]{2}{*}{$\begin{array}{c}\text { Depth } \\
\text { (ft BGL) }\end{array}$} & \multicolumn{3}{|c|}{ Concentration $(\mu \mathrm{g} / \mathrm{L})$} & \multirow[b]{2}{*}{ Sample Description } \\
\hline & & & & $\begin{array}{c}\text { Carbon } \\
\text { Tetrachloride }\end{array}$ & Chloroform & $\begin{array}{l}\text { Methylene } \\
\text { Chloride }\end{array}$ & \\
\hline
\end{tabular}

Samples Collected in June 2013 and April-July 2014

\begin{tabular}{|c|c|c|c|c|c|c|c|}
\hline DW22, Y Motel & YKHYD-W-35344 & $06 / 18 / 13$ & - & $N^{a}$ & ND & ND & $\begin{array}{l}\text { Sample collected from a faucet on the } \\
\text { west side of the Y Motel. This is the } \\
\text { closest point to the well, before the } \\
\text { pressure tank and the water softener. }\end{array}$ \\
\hline DW22, Y Motel & YKMOTEL-W-35345 & 06/18/13 & - & ND & ND & ND & $\begin{array}{l}\text { Sample collected from a faucet in the } \\
\text { bathroom of Room } 14 \text { of the Y Motel. } \\
\text { This was the only unoccupied room } \\
\text { currently at the motel. }\end{array}$ \\
\hline Pit Stop & YKPSTOP-W-35346 & 06/18/13 & - & ND & ND & ND & $\begin{array}{l}\text { Sample collected from a faucet in the } \\
\text { bathroom of the Pit Stop convenience } \\
\text { store, on the southeast part of the } \\
\text { property. The Pit Stop is a fairly new } \\
\text { addition to the motel and is connected } \\
\text { to the same well. }\end{array}$ \\
\hline Janzen & YKPIN9POST-W-35355 & $04 / 17 / 14$ & - & ND & ND & ND & $\begin{array}{l}\text { Sample collected from a faucet on the } \\
\text { north side of the house, post reverse } \\
\text { osmosis treatment. }\end{array}$ \\
\hline Janzen & YKPIN9PRE-W-35354 & $04 / 17 / 14$ & - & ND & ND & ND & $\begin{array}{l}\text { Sample collected from a hydrant east of } \\
\text { the house, pretreatment. }\end{array}$ \\
\hline Metal Works & YKPIN3-W-35349 & $04 / 17 / 14$ & - & ND & ND & ND & $\begin{array}{l}\text { Sample collected from an outside faucet } \\
\text { on the west side of the building. A } \\
\text { water softener is used on the water in } \\
\text { the main building. }\end{array}$ \\
\hline $2009-4$ & YKPIN11-W-35357 & $04 / 17 / 14$ & $270-392$ & ND & ND & ND & $\begin{array}{l}\text { Sample collected from a tap inside the } \\
\text { well house, after letting it run for ten } \\
\text { minutes. Well ID 2009-04. Total depth } \\
=392 \mathrm{ft} \text {. Screen } 1=270-314 \mathrm{ft} \text {, Screen } \\
2=342-366 \mathrm{ft} \text {, Screen } 3=372-392 \mathrm{ft} \text {. } \\
\text { Well is operational but is not used } \\
\text { because of sulfur smell. }\end{array}$ \\
\hline
\end{tabular}




\begin{tabular}{|c|c|c|c|c|c|c|c|}
\hline \multirow[b]{2}{*}{ Location } & \multirow[b]{2}{*}{ Sample } & \multirow[b]{2}{*}{$\begin{array}{l}\text { Sample } \\
\text { Date }\end{array}$} & \multirow[b]{2}{*}{$\begin{array}{l}\text { Depth } \\
\text { (ft BGL) }\end{array}$} & \multicolumn{3}{|c|}{ Concentration $(\mu \mathrm{g} / \mathrm{L})$} & \multirow[b]{2}{*}{ Sample Description } \\
\hline & & & & $\begin{array}{c}\text { Carbon } \\
\text { Tetrachloride }\end{array}$ & Chloroform & $\begin{array}{l}\text { Methylene } \\
\text { Chloride }\end{array}$ & \\
\hline
\end{tabular}

Samples Collected in June 2013 and April-July 2014 (cont.)

77-1 (PW4) YKWELL771-W-35356

ND

Makovicka

YKPIN7-W-35353

Onnen

YKPIN6-W-35352

Travis

YKPIN5-W-35351

Hoblyn

YKPIN4-W-35350

Co-op

YKPIN2-W-35348

Bonde

YKBONDE-W-35360

YKOLSON-W-35361

Samples Collected in December 2014

2009-4

YKPWS2009-4-W-36865
2.2

$04 / 17 / 14$
$04 / 17 / 14$
$04 / 17 / 14$
$04 / 17 / 14$
$04 / 17 / 14$
$07 / 10 / 14$
$07 / 10 / 14$

ND

ND

ND

ND

ND

ND

ND

$N D$

ND

ND

ND

ND

ND
Sample collected from tap inside well house, after letting it run for ten min Well ID 77-1, PWS ID NE3118706. Total depth $=344 \mathrm{ft}$. Screen $=170$

$344 \mathrm{ft}$. Well in use for public drinking water. Chosen as alternative sampling point (Pin \#11 out of service).

Sample collected from a hydrant east of the house, near the red shed.

Sample collected from a faucet on the north side of the house.

Sample collected at an outside faucet at the southeast side of the house.

Sample collected from a hydrant north of the house.

Sample collected from a sink in the break/lunch room of the main building. Water is untreated.

Sample collected from a faucet on the north side of the house, before treatment/filtration.

Sample collected from faucet on east side of the house, near the well.

Sample collected from a tap inside the well house after letting it run for ten minutes. Well ID 2009-04. Total depth $=392 \mathrm{ft}$. Screen $1=270-314 \mathrm{ft}$ Screen $2=342-366 \mathrm{ft}$, Screen $3=$ 372-392 ft. 


\begin{tabular}{|c|c|c|c|c|c|c|c|}
\hline \multirow[b]{2}{*}{ Location } & \multirow[b]{2}{*}{ Sample } & \multirow[b]{2}{*}{$\begin{array}{l}\text { Sample } \\
\text { Date }\end{array}$} & \multirow[b]{2}{*}{$\begin{array}{l}\text { Depth } \\
\text { (ft BGL) }\end{array}$} & \multicolumn{3}{|c|}{ Concentration $(\mu \mathrm{g} / \mathrm{L})$} & \multirow[b]{2}{*}{ Sample Description } \\
\hline & & & & $\begin{array}{c}\text { Carbon } \\
\text { Tetrachloride }\end{array}$ & Chloroform & $\begin{array}{l}\text { Methylene } \\
\text { Chloride }\end{array}$ & \\
\hline
\end{tabular}

Samples Collected in December 2014 (cont.)

$2009-6$

YKPWS2009-6-W-36866

$12 / 16 / 14$

77-1 (PW4)

YKPWS77-1-W-36867

$12 / 16 / 14$

$12 / 16 / 14$

$12 / 16 / 14$

Co-op

YKCOOP-W-36859

YKDANIELSON-W-36864

$12 / 16 / 14$

$12 / 16 / 14$

Hoblyn

Janzen

YKHOBLYN-W-36861

$12 / 16 / 14$

YKKNIERIEM-W-36854

$12 / 16 / 14$

Makovika

YKMAKOVICKA-W-36857

$12 / 16 / 14$

YKB\&B-W-36856
YKOLSON-W-36863
$12 / 16 / 14$
ND

ND

ND

ND

ND

ND

ND

ND

ND

ND

ND$$
2.4
$$

ND
ND

ND

ND

ND

ND
Sample collected from a tap inside the well house after letting it run for ten minutes. Well ID 2009-06. Tota depth $=377 \mathrm{ft}$. Pump set at $250 \mathrm{ft}$.

Pump intake at $256 \mathrm{ft}$.

Sample collected from tap inside well house after letting it run for ten minutes. Well ID 77-1, PWS ID NE3118706. Total depth $=344 \mathrm{ft}$ Screen $=170-344 \mathrm{ft}$.

Sample collected from a faucet on the north side of the house, before treatment/filtration.

Sample collected from a sink in the break/lunch room of the main building. Water is untreated.

Sample collected from a hydrant east of the house.

Sample collected from a hydrant on the east side of the shop.

Sample collected from a hydrant north of the house.

Sample collected from a hydrant east of the house, pretreatment.

Sample collected from faucet on east side of the house, near the well. Kayton is the daughter of Olson and new owner of the former Olson property.

Sample collected from a hydrant east of the house, near the red shed. 


\begin{tabular}{|c|c|c|c|c|c|c|c|}
\hline \multirow[b]{2}{*}{ Location } & \multirow[b]{2}{*}{ Sample } & \multirow[b]{2}{*}{$\begin{array}{l}\text { Sample } \\
\text { Date }\end{array}$} & \multirow[b]{2}{*}{$\begin{array}{l}\text { Depth } \\
\text { (ft BGL) }\end{array}$} & \multicolumn{3}{|c|}{ Concentration $(\mu \mathrm{g} / \mathrm{L})$} & \multirow[b]{2}{*}{ Sample Description } \\
\hline & & & & $\begin{array}{l}\text { Carbon } \\
\text { Tetrachloride }\end{array}$ & Chloroform & $\begin{array}{l}\text { Methylene } \\
\text { Chloride }\end{array}$ & \\
\hline \multicolumn{8}{|c|}{ Samples Collected in December 2014 (cont.) } \\
\hline Onnen & YKONNEN-W-36858 & $12 / 16 / 14$ & & ND & ND & ND & $\begin{array}{l}\text { Sample collected from an outside faucet } \\
\text { on the west side of the building. A } \\
\text { water softener is used on the water in } \\
\text { the main building. }\end{array}$ \\
\hline Steever & YKSTEEVER-W-36855 & $12 / 16 / 14$ & & ND & ND & ND & $\begin{array}{l}\text { Sample collected from a faucet on the } \\
\text { north side of the house. }\end{array}$ \\
\hline Travis & YKTRAVIS-W-36860 & $12 / 16 / 14$ & & ND & ND & ND & $\begin{array}{l}\text { Sample collected from a faucet on the } \\
\text { south side of the house. }\end{array}$ \\
\hline \multicolumn{8}{|c|}{ Samples Collected in March 2015} \\
\hline $2009-4$ & YKPWS2009-4-W-36881 & $03 / 24 / 15$ & & ND & ND & ND & $\begin{array}{l}\text { Sample collected at an outside faucet at } \\
\text { the southeast side of the house. }\end{array}$ \\
\hline $2009-6$ & YKPWS2009-6-W-36882 & $03 / 24 / 15$ & & ND & ND & ND & $\begin{array}{l}\text { Sample collected from a tap inside the } \\
\text { well house after letting it run for ten } \\
\text { minutes. Well ID } 2009-06 \text {. Total } \\
\text { depth = } 377 \mathrm{ft} \text {. Pump set at } 250 \mathrm{ft} \text {. } \\
\text { Pump intake at } 256 \mathrm{ft} \text {. }\end{array}$ \\
\hline 77-1 (PW4) & YKPWS77-1-W-36883 & $03 / 24 / 15$ & & ND & ND & ND & $\begin{array}{l}\text { Sample collected from tap inside well } \\
\text { house after letting it run for ten } \\
\text { minutes. Well ID } 77-1 \text {, PWS ID } \\
\text { NE3118706. Total depth = } 344 \mathrm{ft} . \\
\text { Screen }=170-344 \mathrm{ft} .\end{array}$ \\
\hline Bonde & YKBONDE-W-36877 & $03 / 24 / 15$ & & ND & ND & ND & $\begin{array}{l}\text { Sample collected from a faucet on the } \\
\text { north side of the house, before } \\
\text { treatment/filtration. }\end{array}$ \\
\hline Co-op & YKCOOP-W-36874 & $03 / 24 / 15$ & & 5.1 & ND & ND & $\begin{array}{l}\text { Sample collected from a sink in the } \\
\text { break/lunch room of the main building } \\
\text { Water is untreated. }\end{array}$ \\
\hline Danielson & YKDANIELSON-W-36879 & $03 / 24 / 15$ & & ND & ND & ND & $\begin{array}{l}\text { Sample collected from a hydrant east of } \\
\text { the house. }\end{array}$ \\
\hline Driewer & YKDRIEWIER-W-36880 & $03 / 24 / 15$ & & ND & ND & ND & $\begin{array}{l}\text { Sample collected from a hydrant on the } \\
\text { east side of the shop. }\end{array}$ \\
\hline
\end{tabular}




\begin{tabular}{|c|c|c|c|c|c|c|c|}
\hline \multirow[b]{2}{*}{ Location } & \multirow[b]{2}{*}{ Sample } & \multirow[b]{2}{*}{$\begin{array}{c}\text { Sample } \\
\text { Date }\end{array}$} & \multirow[b]{2}{*}{$\begin{array}{c}\text { Depth } \\
\text { (ft BGL) }\end{array}$} & \multicolumn{3}{|c|}{ Concentration $(\mu \mathrm{g} / \mathrm{L})$} & \multirow[b]{2}{*}{ Sample Description } \\
\hline & & & & $\begin{array}{l}\text { Carbon } \\
\text { Tetrachloride }\end{array}$ & Chloroform & $\begin{array}{l}\text { Methylene } \\
\text { Chloride }\end{array}$ & \\
\hline \multicolumn{8}{|c|}{ Samples Collected in March 2015 (cont.) } \\
\hline Hoblyn & YKHOBLYN-W-36876 & $03 / 24 / 15$ & & ND & ND & ND & $\begin{array}{l}\text { Sample collected from a hydrant north of } \\
\text { the house. }\end{array}$ \\
\hline Janzen & YKKNIERIEM-W-36869 & $03 / 24 / 15$ & & ND & ND & ND & $\begin{array}{l}\text { Sample collected from a hydrant east of } \\
\text { the house, pretreatment. }\end{array}$ \\
\hline Kayton & YKKAYTON-W-36878 & $03 / 24 / 15$ & & 2.4 & ND & ND & $\begin{array}{l}\text { Sample collected from faucet on east } \\
\text { side of the house, near the well. } \\
\text { Kayton is the daughter of Olson and } \\
\text { new owner of the former Olson } \\
\text { property. }\end{array}$ \\
\hline Makovicka & YKMAKOVICKA-W-36872 & $03 / 24 / 15$ & & ND & ND & ND & $\begin{array}{l}\text { Sample collected from a hydrant east of } \\
\text { the house, near the red shed. }\end{array}$ \\
\hline Metal Works & YKB\&B-W-36871 & $03 / 24 / 15$ & & ND & ND & ND & $\begin{array}{l}\text { Sample collected from an outside faucet } \\
\text { on the west side of the building. A } \\
\text { water softener is used on the water in } \\
\text { the main building. }\end{array}$ \\
\hline Onnen & YKONNEN-W-36873 & $03 / 24 / 15$ & & ND & ND & ND & $\begin{array}{l}\text { Sample collected from a faucet on the } \\
\text { north side of the house. }\end{array}$ \\
\hline Steever & YKSTEEVER-W-36870 & $03 / 24 / 15$ & & ND & ND & ND & $\begin{array}{l}\text { Sample collected from a faucet on the } \\
\text { south side of the house. }\end{array}$ \\
\hline Travis & YKTRAVIS-W-36875 & $03 / 24 / 15$ & & ND & ND & ND & $\begin{array}{l}\text { Sample collected at an outside faucet at } \\
\text { the southeast side of the house. }\end{array}$ \\
\hline
\end{tabular}

a ND, compound analyzed for but not detected at a level greater than or equal to the method detection limit $(<1 \mu \mathrm{g} / \mathrm{L})$. 


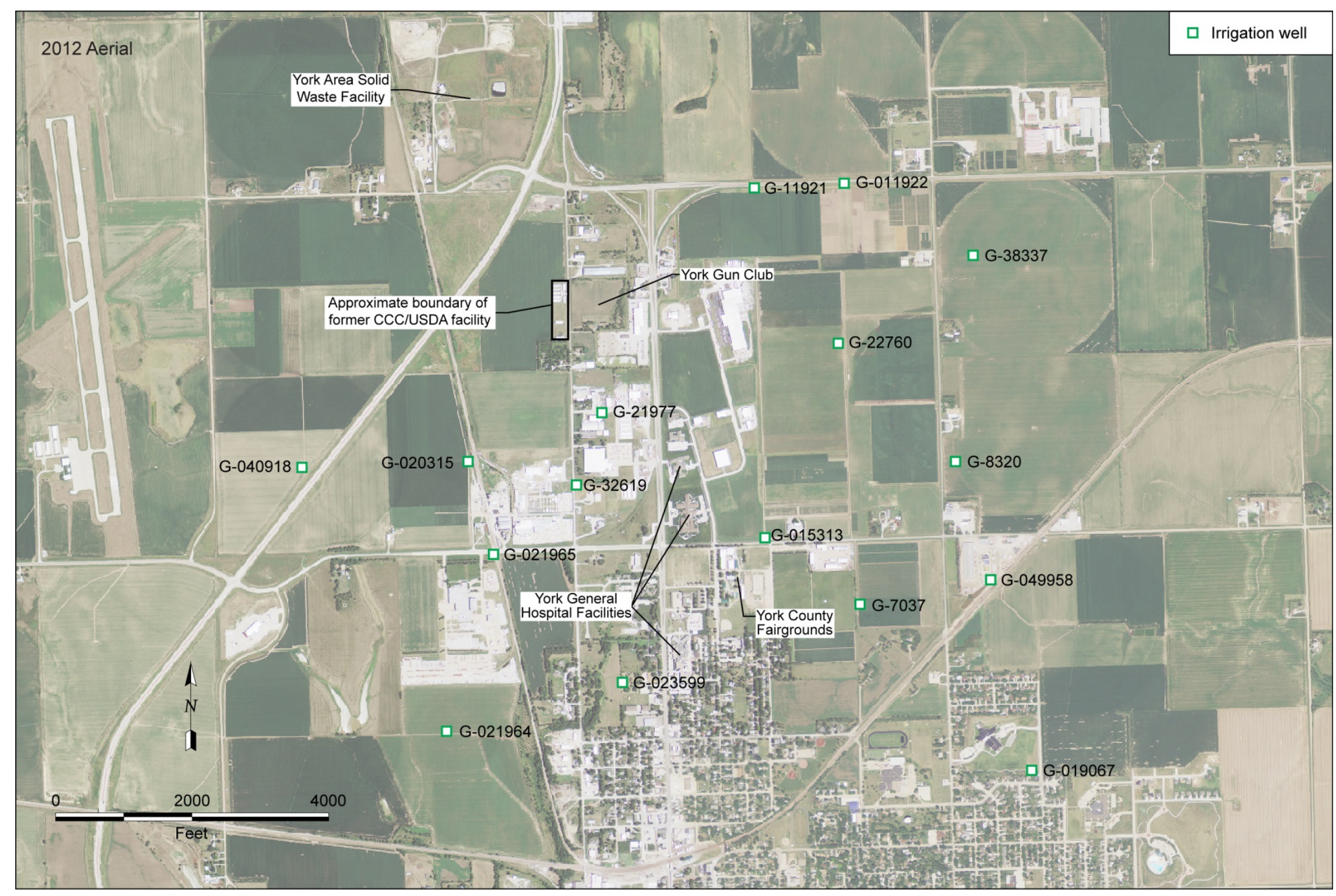

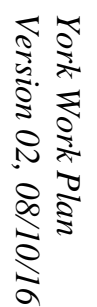

FIGURE 2.1 Locations of the former CCC/USDA facility and selected current community facilities, with approximate locations of irrigation wells in the targeted investigation area. Source of aerial photograph: USDA (2012). 


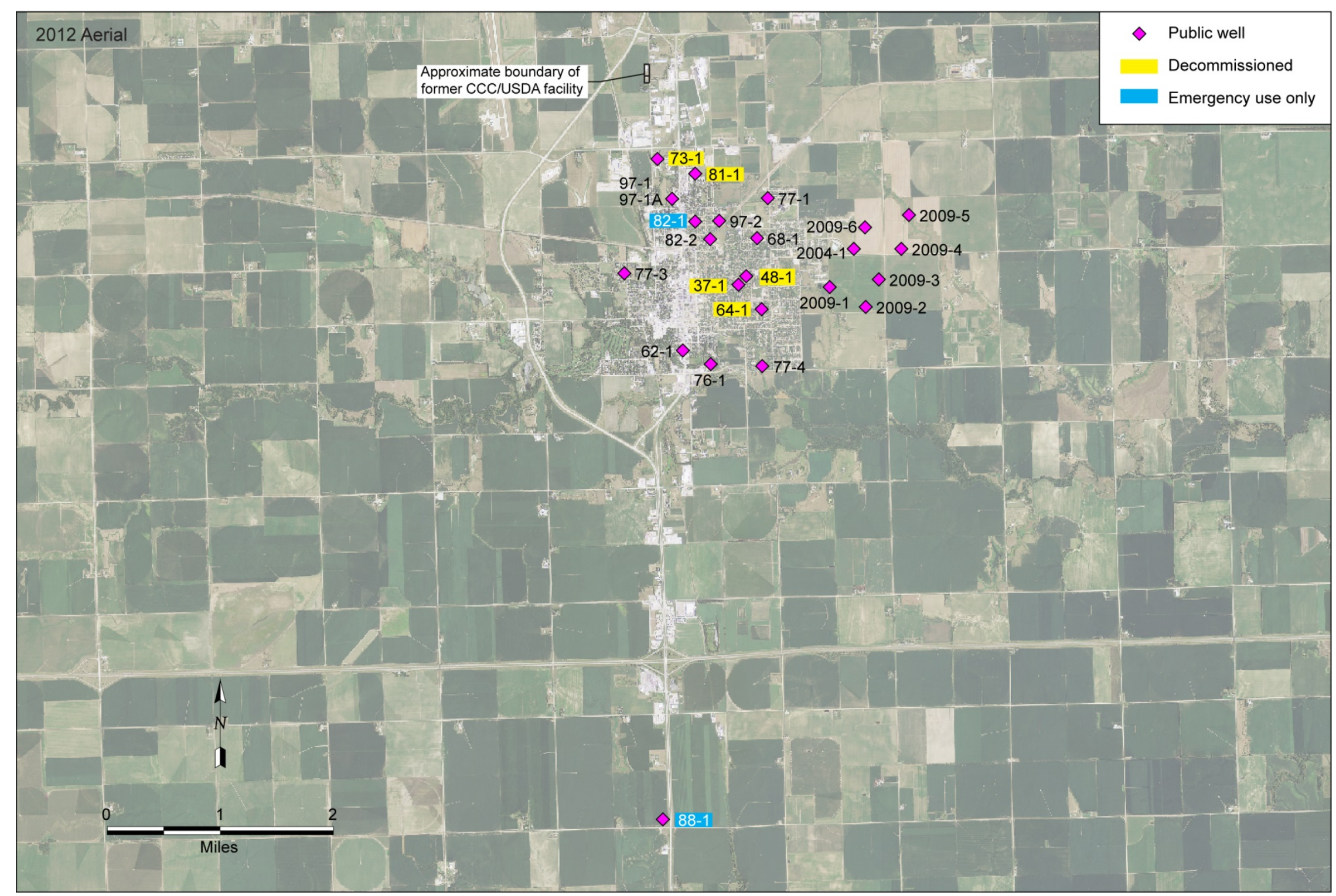

FIGURE 2.2 Locations and status of the York public water supply wells. Source of aerial photograph: USDA (2012). 


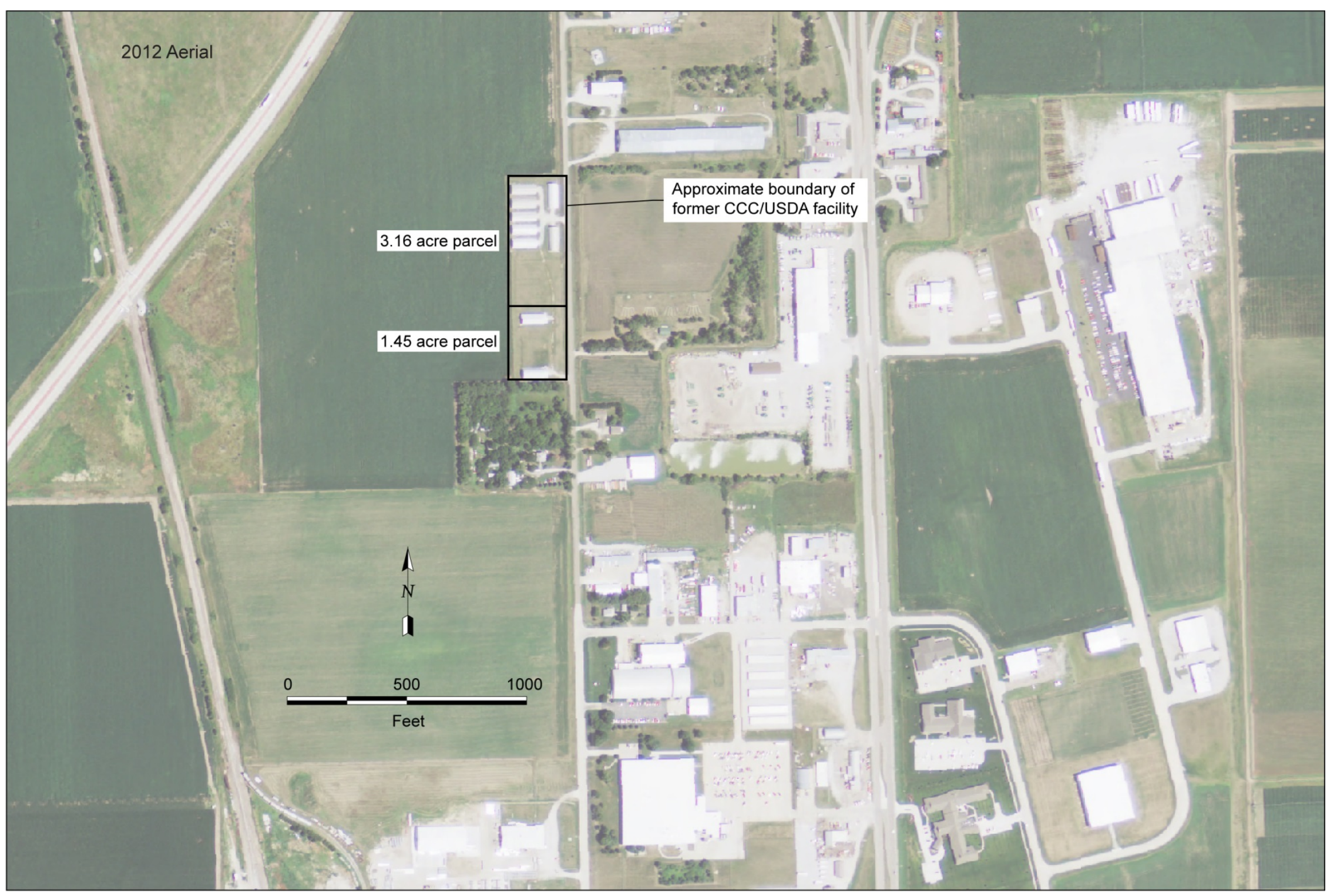

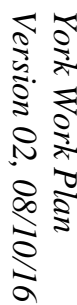

FIGURE 2.3 Approximate locations of parcels leased by the CCC/USDA for grain storage in 1950-1967 (1.45 acres) and 1950-1974 (3.16 acres). Source of aerial photograph: USDA (2012). 


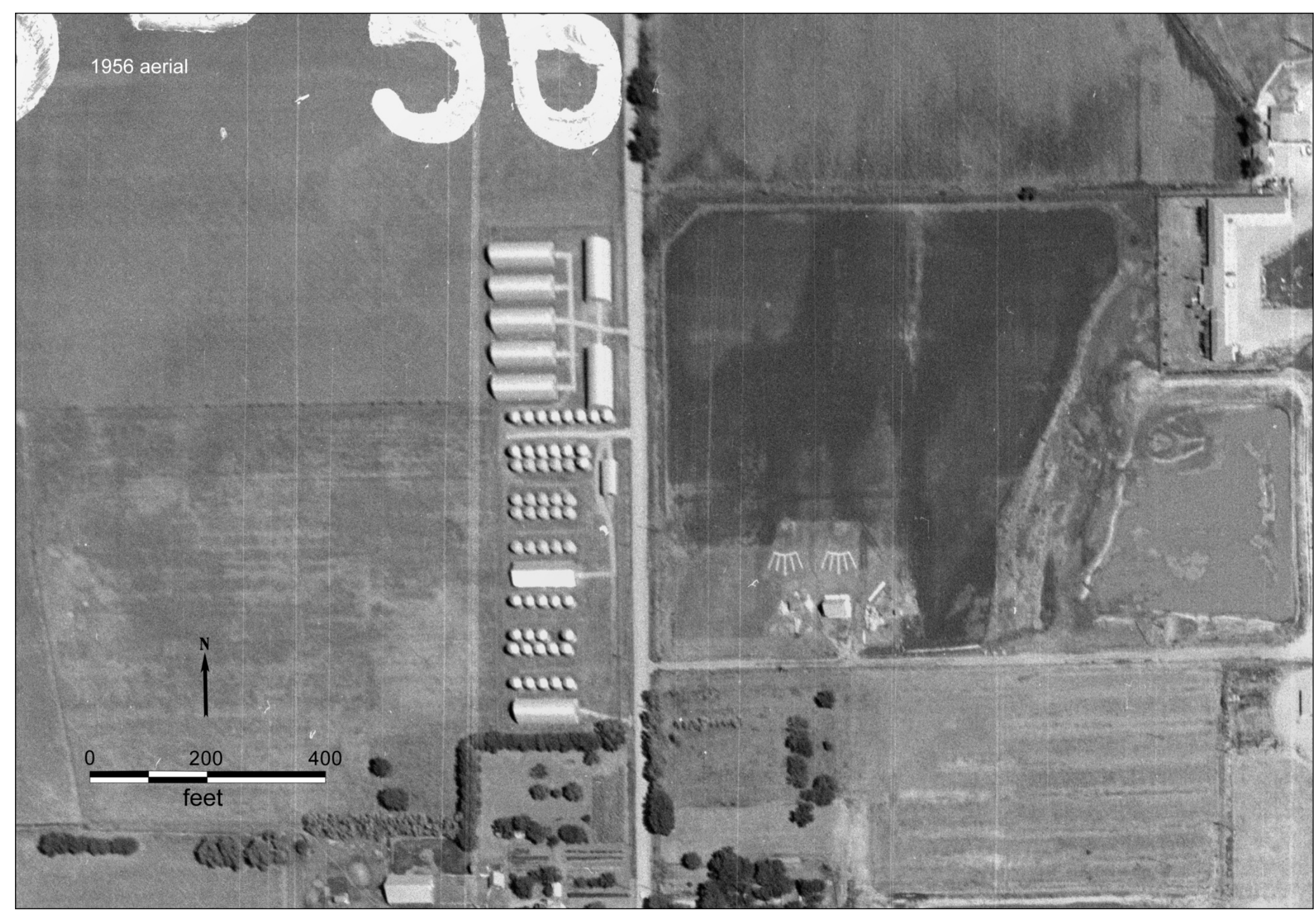

5
5
0
0
0
0
0
0
0
0
0
0
0
0
0

FIGURE 2.4 The former CCC/USDA grain storage facility in 1956. Source of aerial photograph: USDA (1956). 


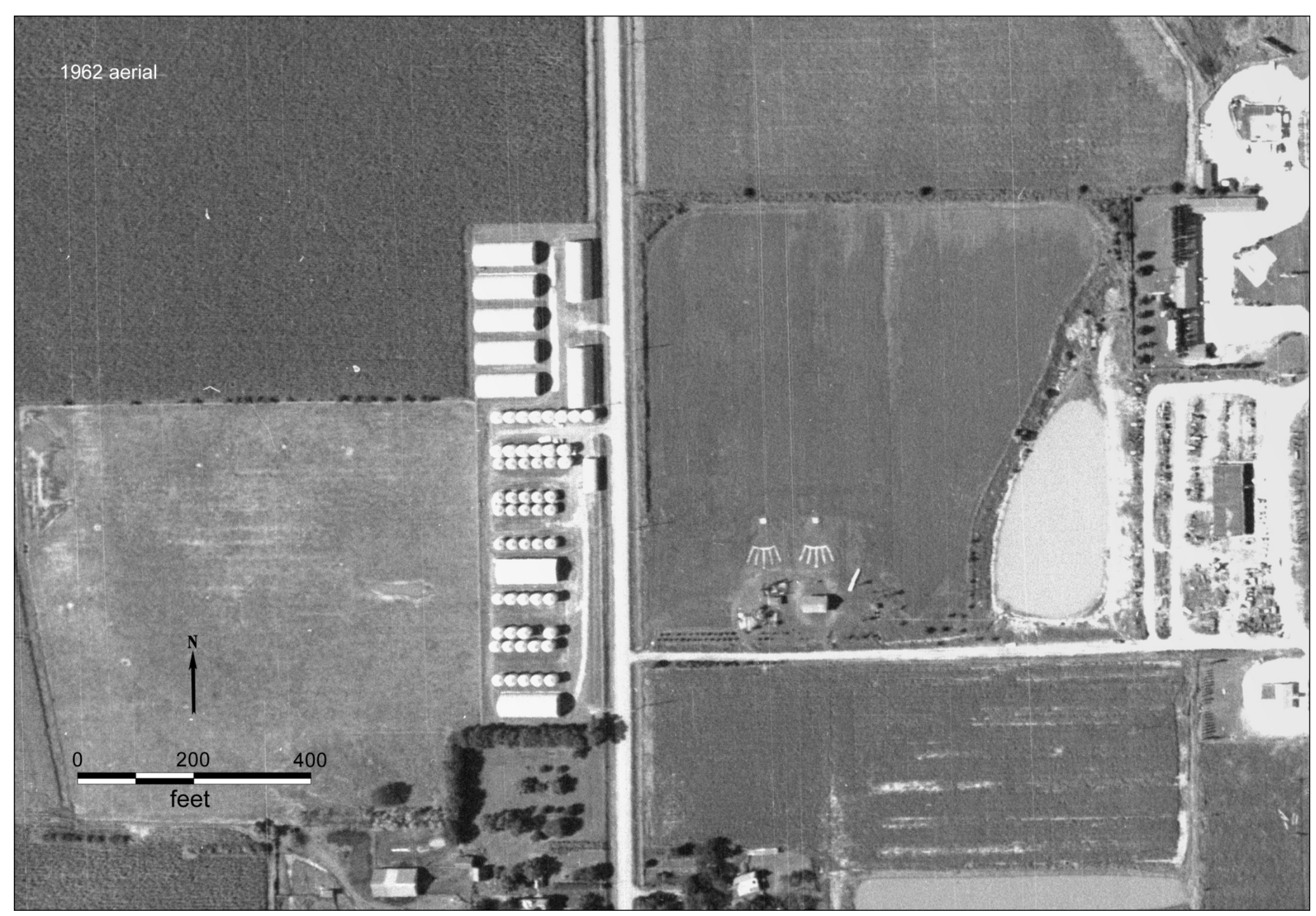

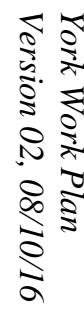

FIGURE 2.5 The former CCC/USDA grain storage facility in 1962. Source of aerial photograph: USDA (1962). 


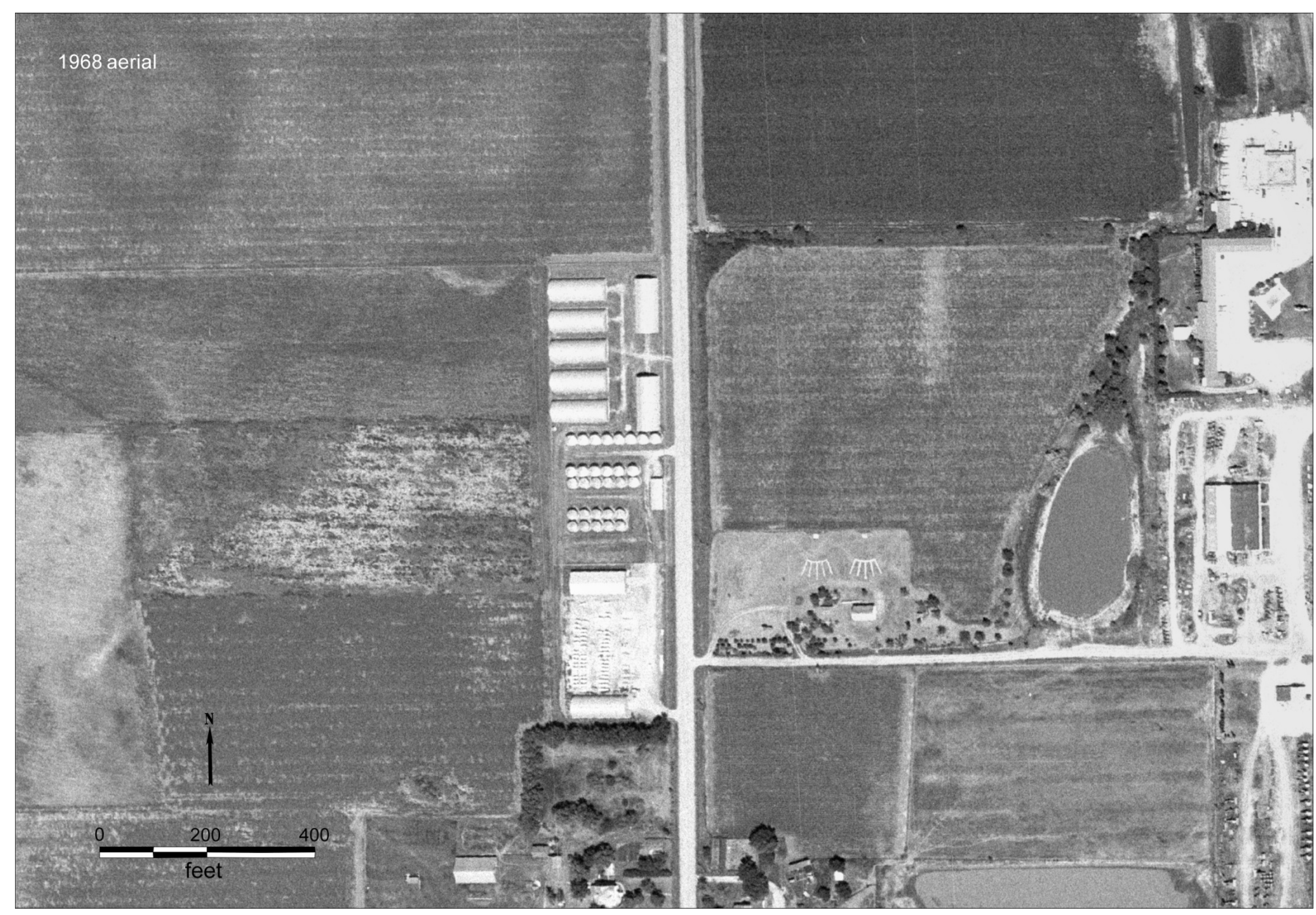

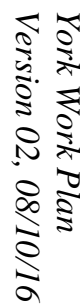

FIGURE 2.6 The former CCC/USDA grain storage facility in 1968. Source of aerial photograph: USDA (1968). 


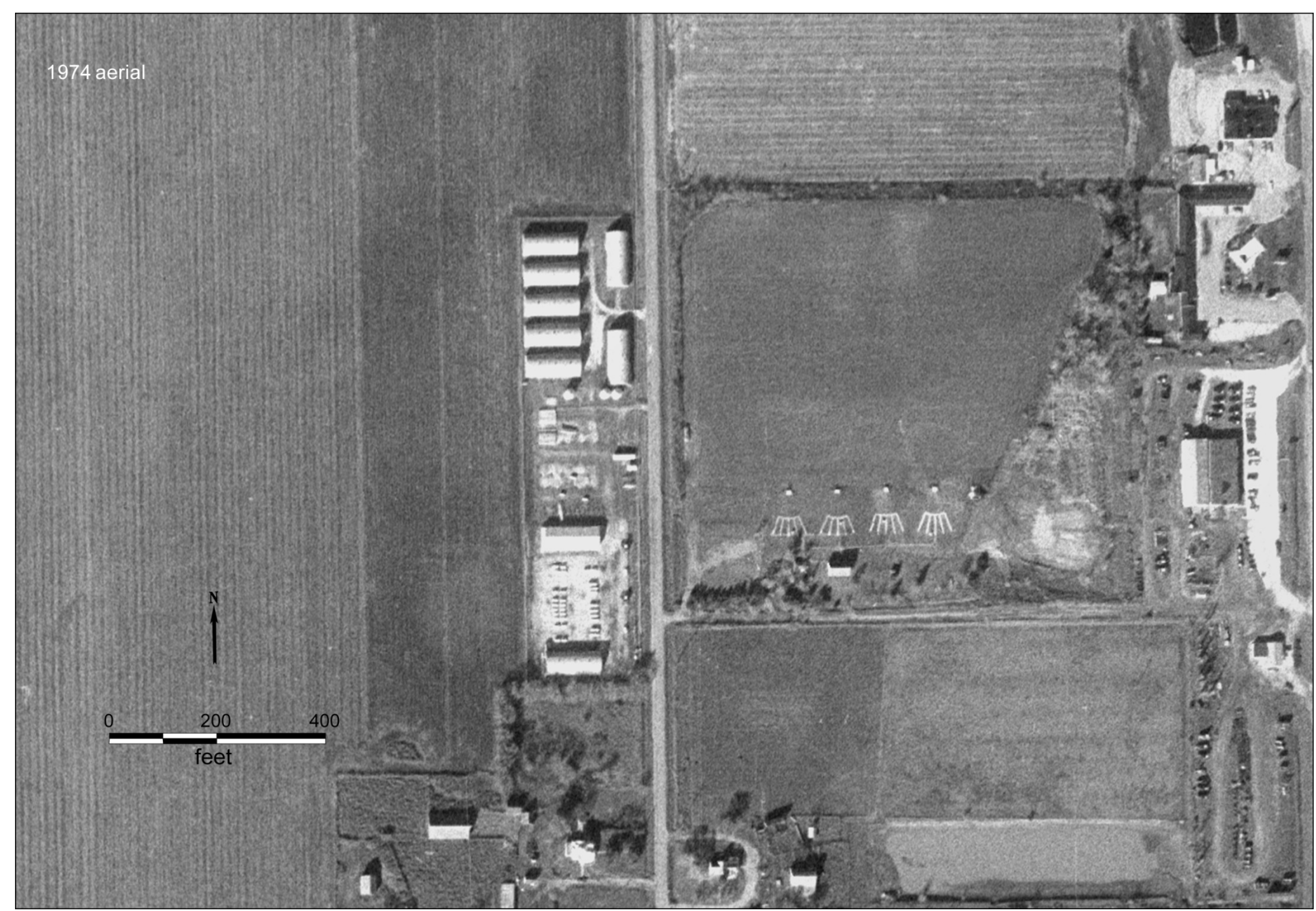

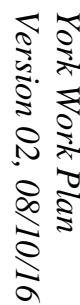

FIGURE 2.7 The former CCC/USDA grain storage facility in 1974. Source of aerial photograph: USDA (1974). 


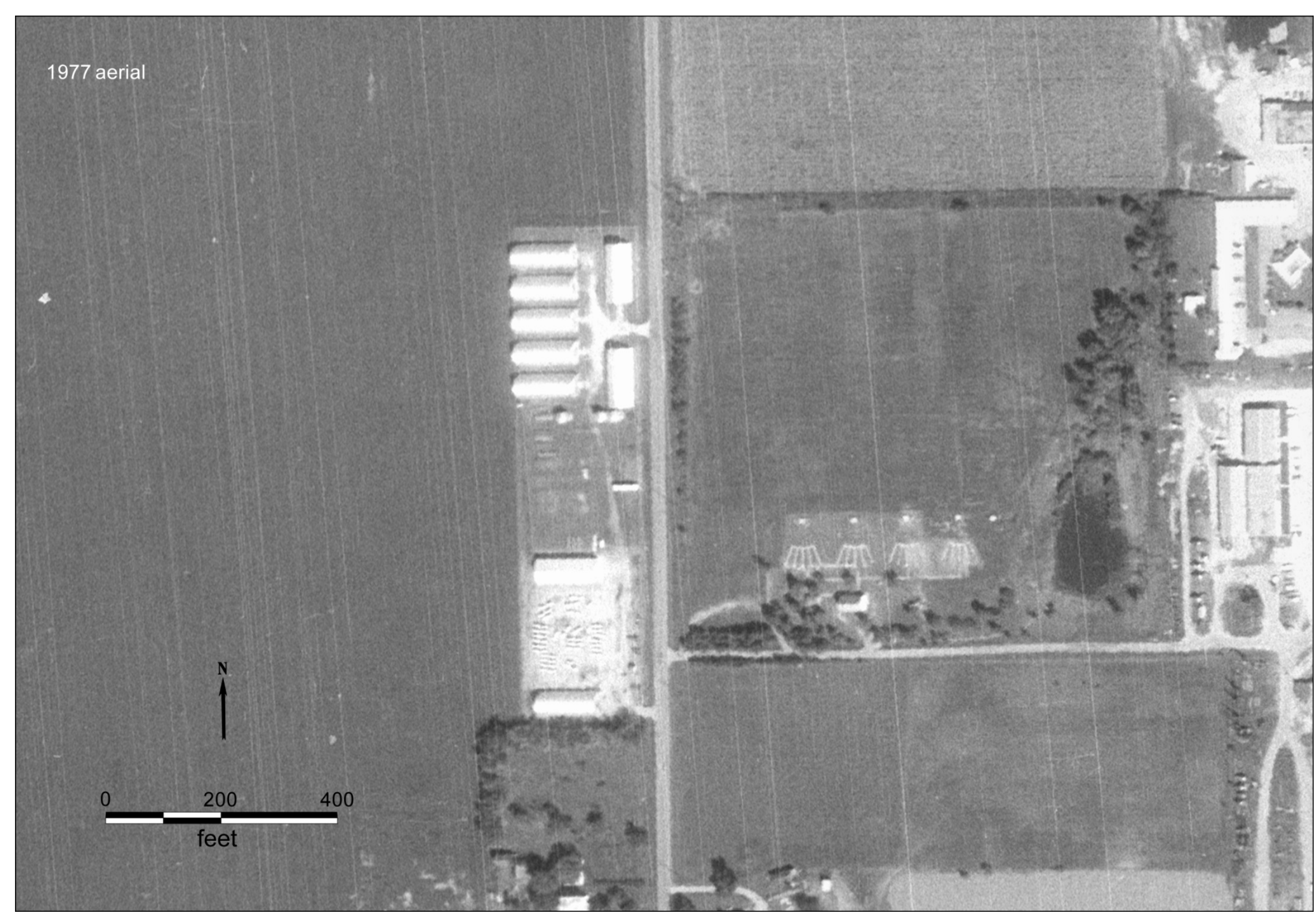

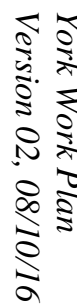

FIGURE 2.8 The former CCC/USDA grain storage facility in 1977. Source of aerial photograph: USDA (1977) 


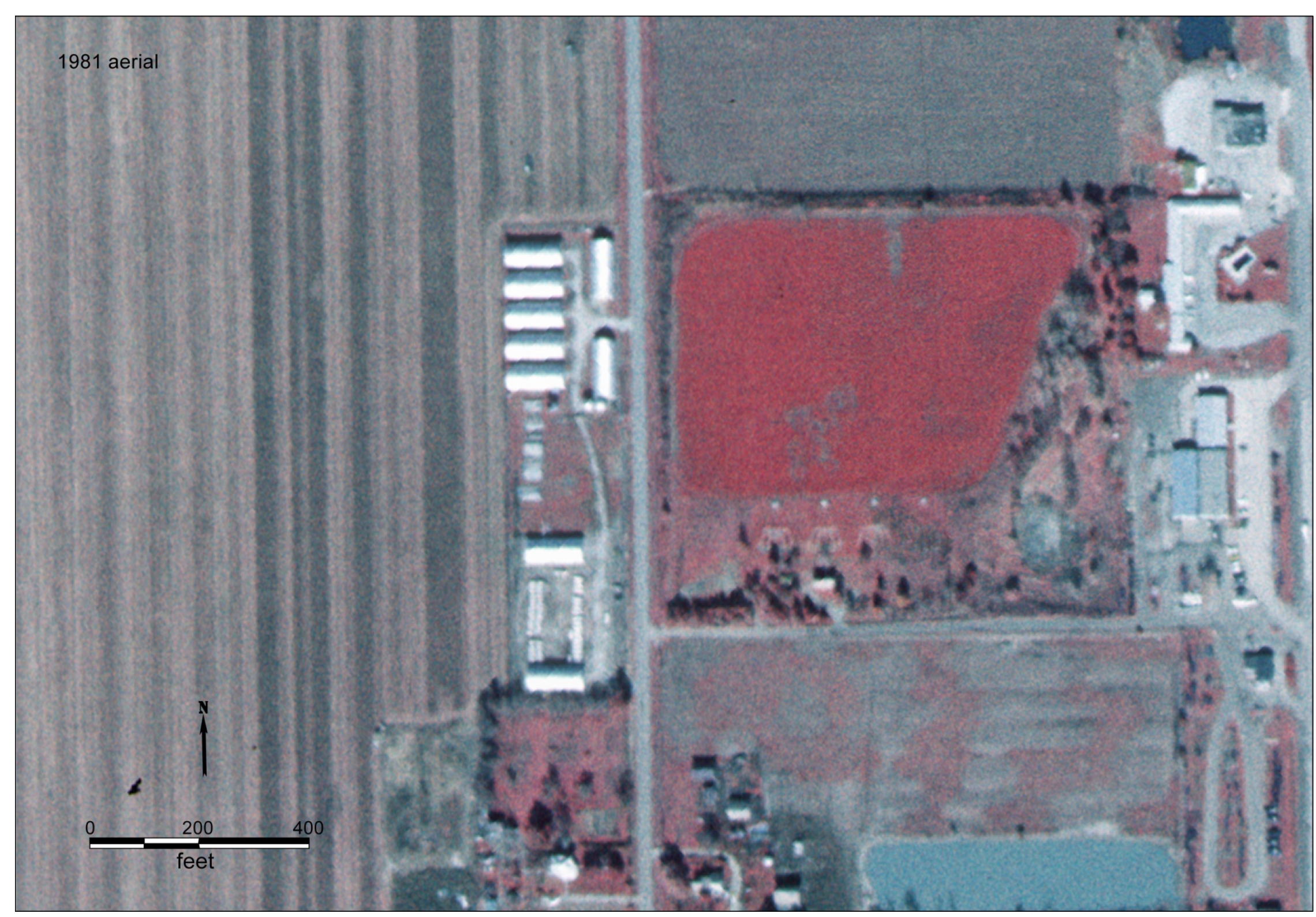

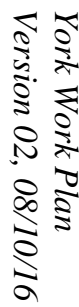

FIGURE 2.9 The former CCC/USDA grain storage facility in 1981. Source of aerial photograph: USDA (1981). 


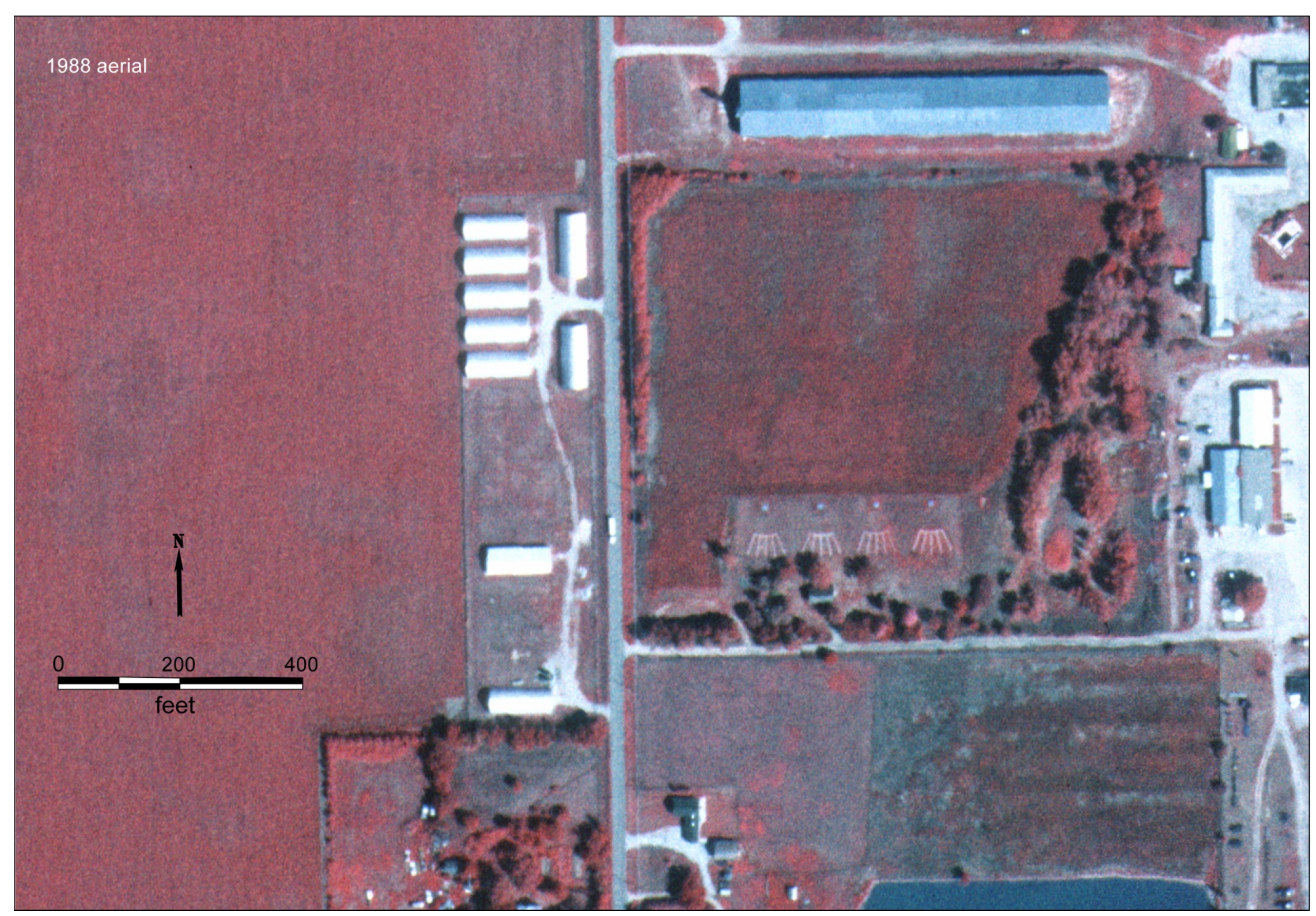

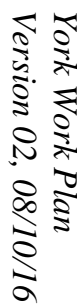

FIGURE 2.10 The former CCC/USDA grain storage facility in 1988. Source of aerial photograph: USDA (1988). 


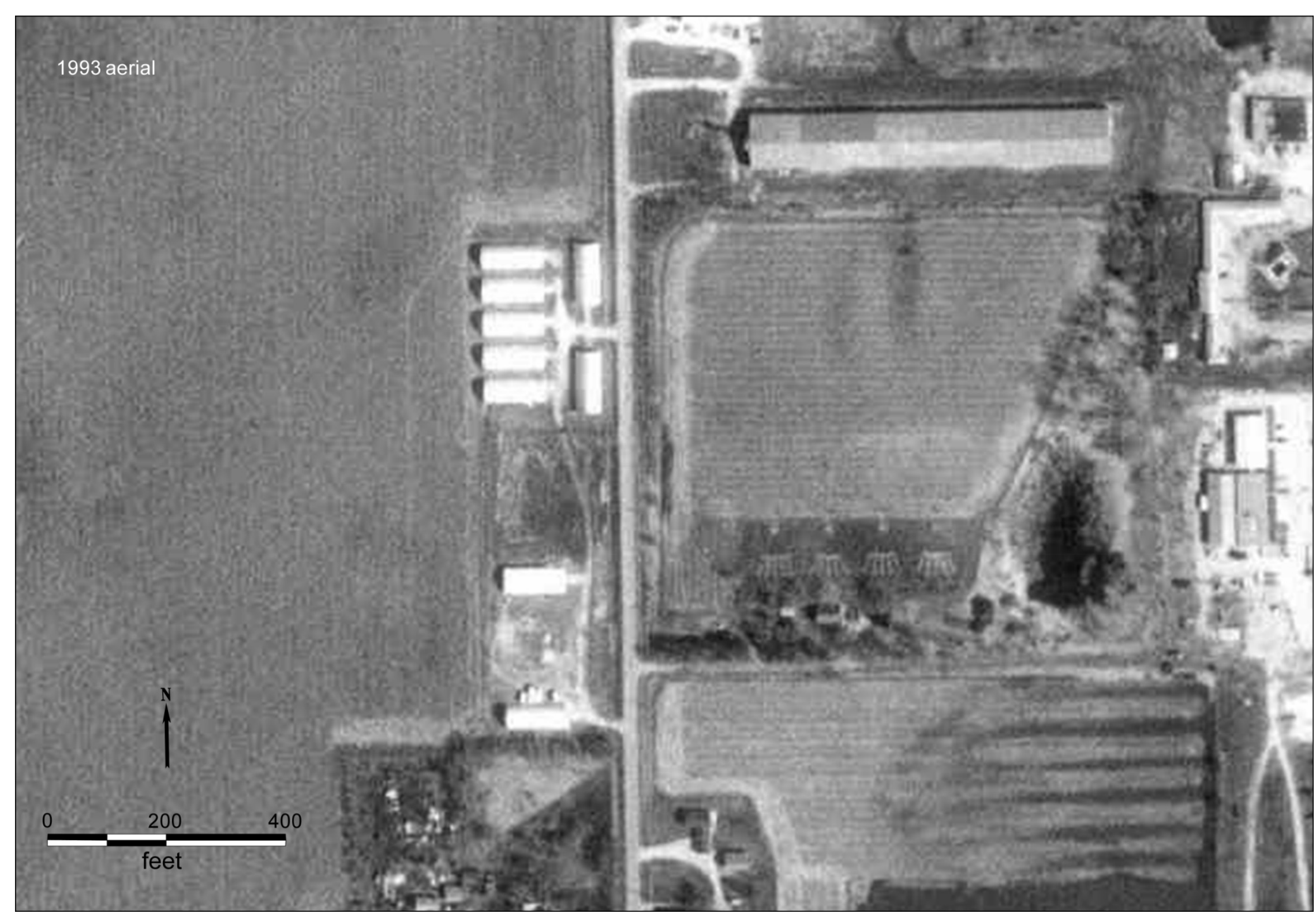

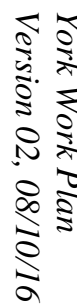

FIGURE 2.11 The former CCC/USDA grain storage facility in 1993. Source of aerial photograph: USDA (1993). 


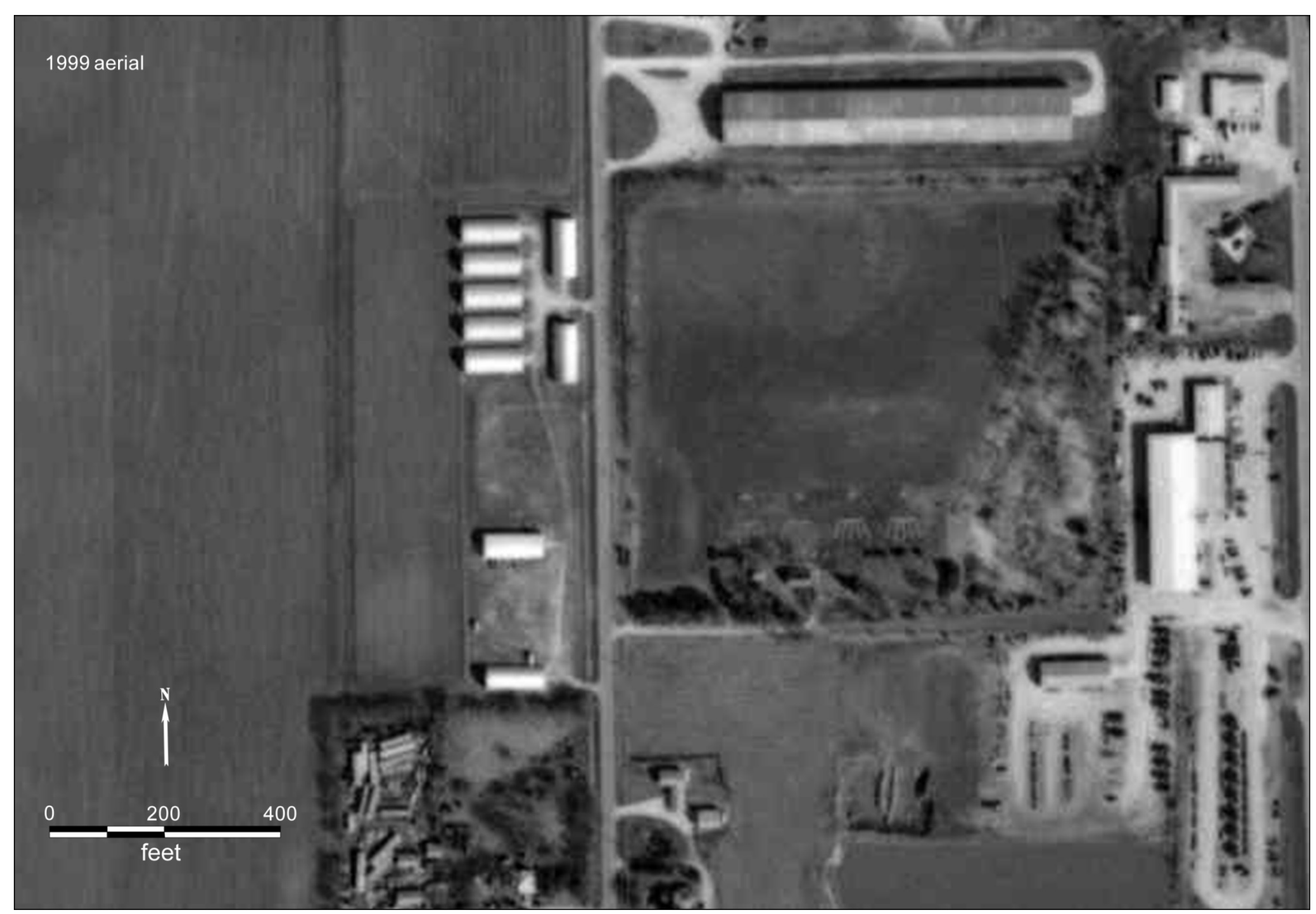

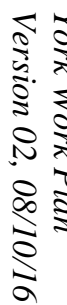

FIGURE 2.12 The former CCC/USDA grain storage facility in 1999. Source of aerial photograph: USDA (1999). 


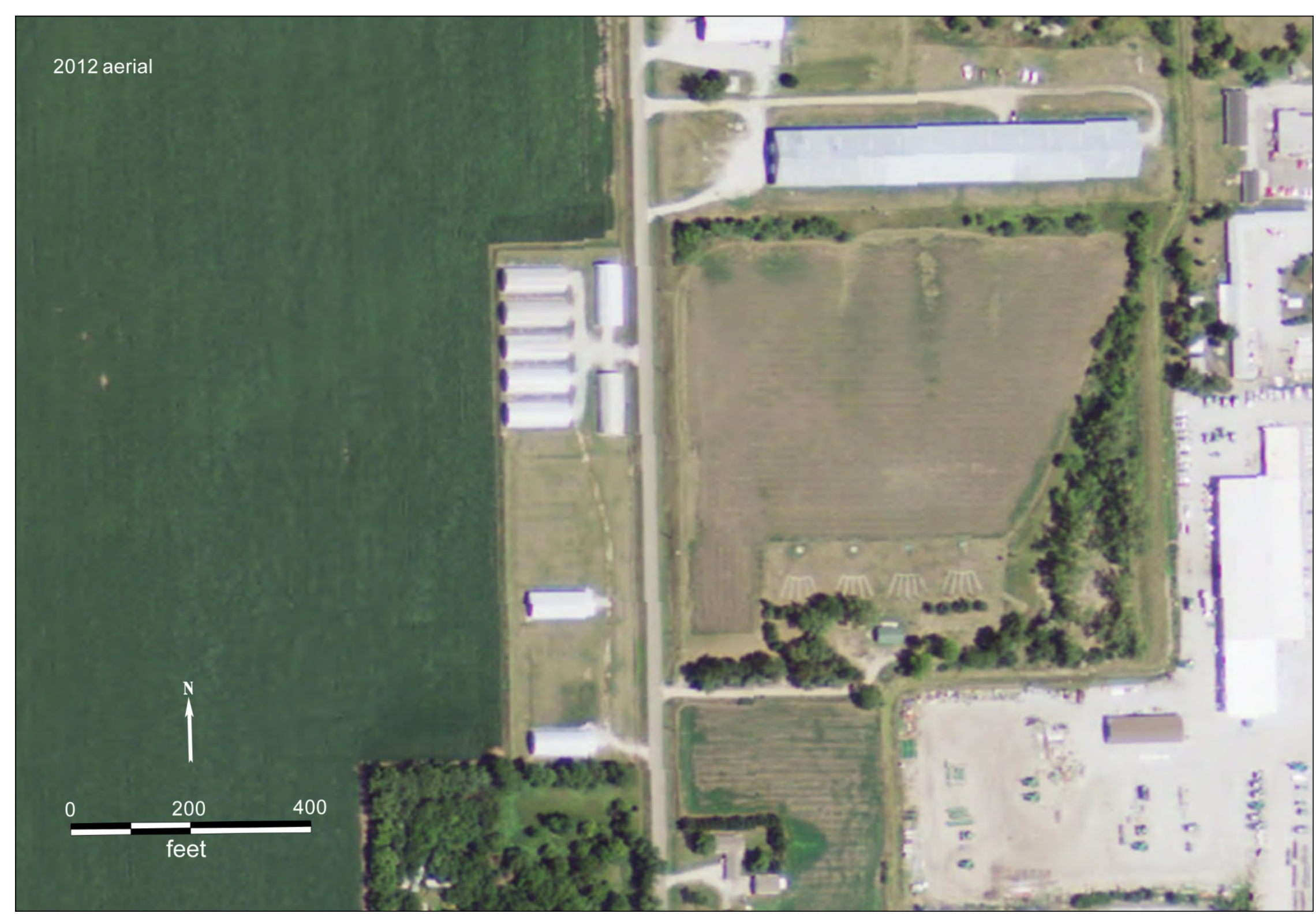

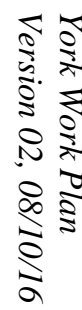

FIGURE 2.13 The former CCC/USDA grain storage facility in 2012. Source of aerial photograph: USDA (2012). 


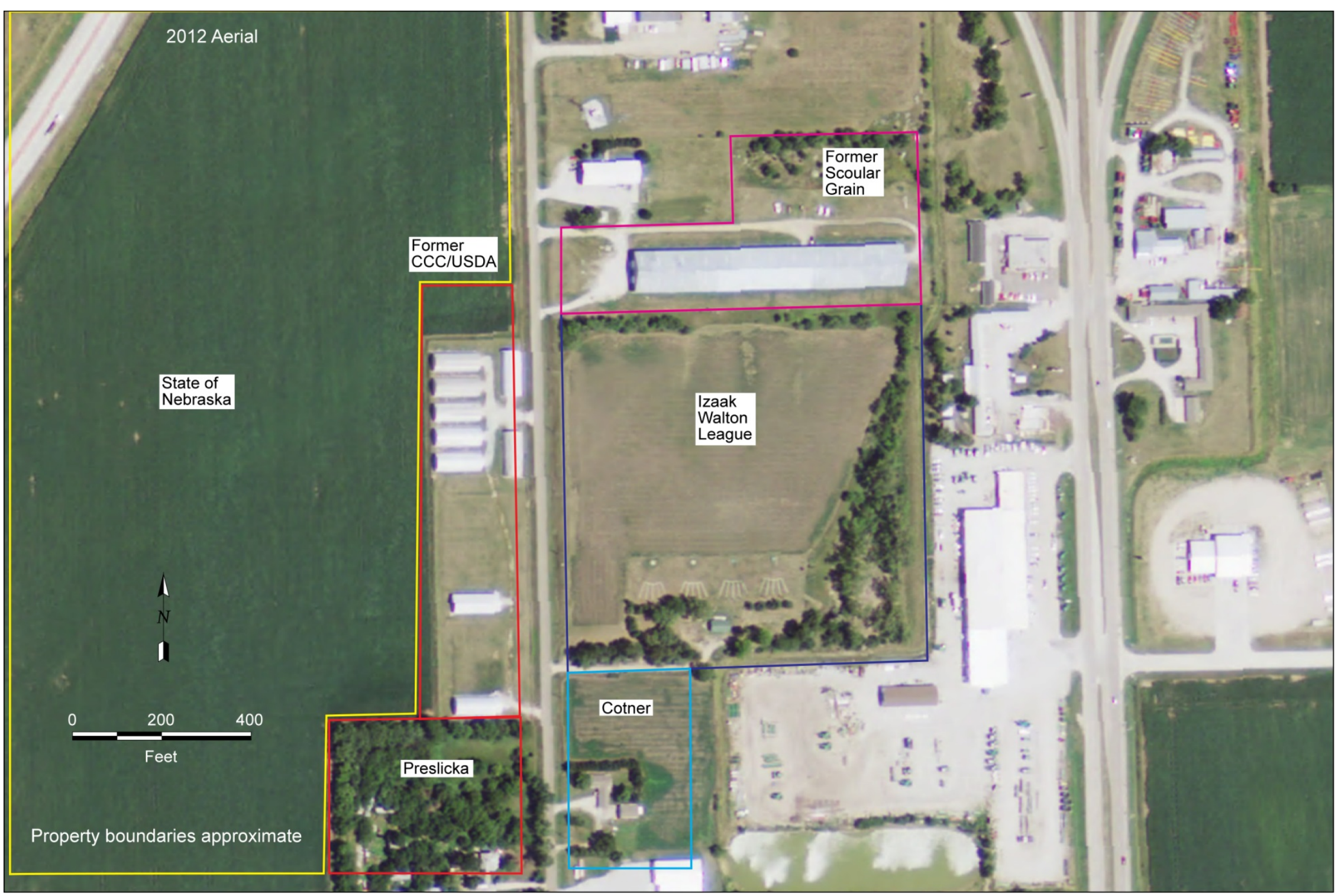

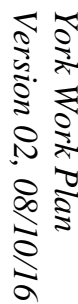

FIGURE 2.14 Approximate boundaries of properties near the former CCC/USDA facility. Source of aerial photograph: USDA (2012) 


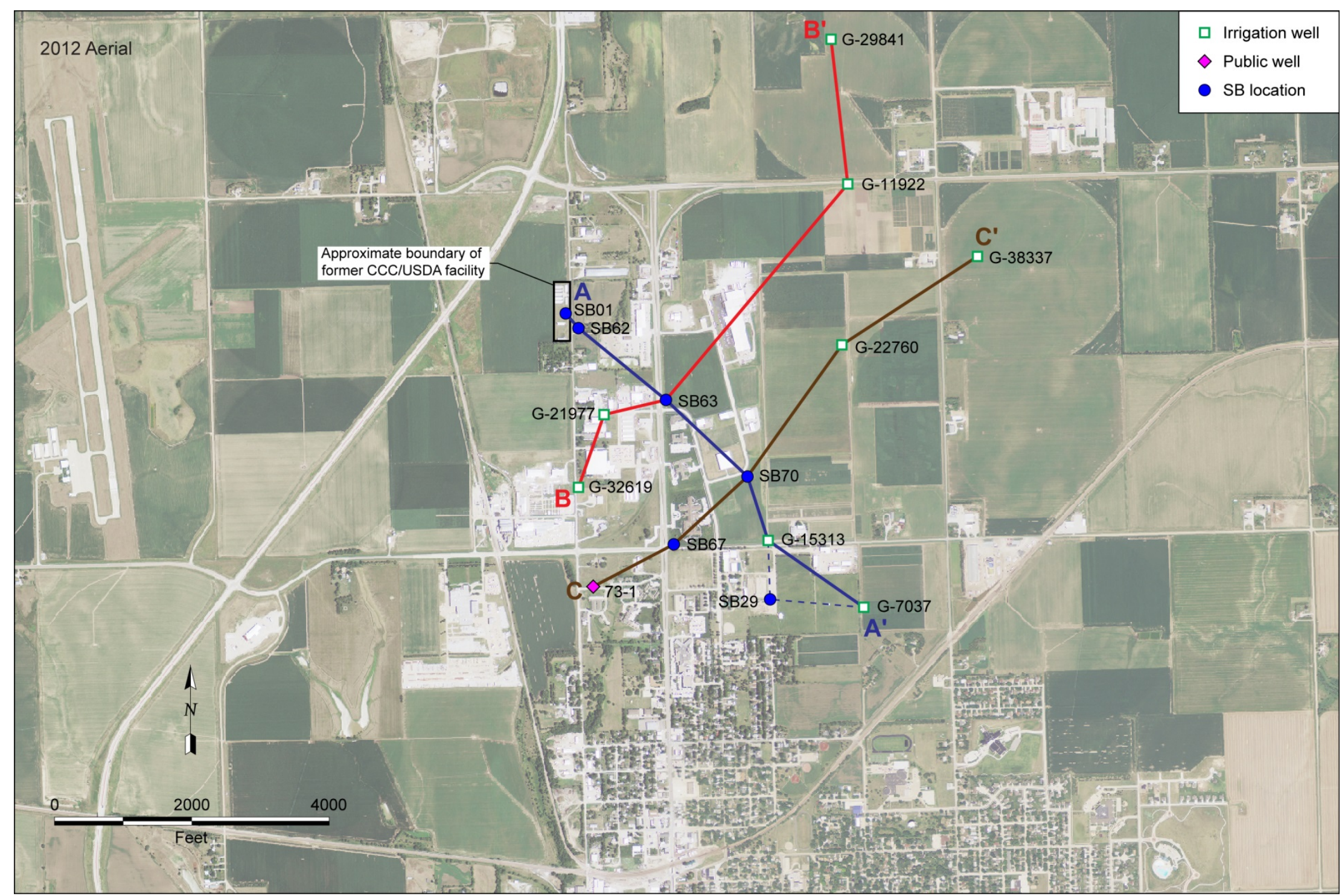

FIGURE 2.15 Approximate locations of the wells and investigative borings that provided lithologic information used to develop local hydrostratigraphic interpretations in the 1993-1995 investigations (Argonne 1993, 1994, 1995a,b), with locations of interpretive cross sections A-A', B-B', and C-C'. Source of aerial photograph: USDA (2012). 


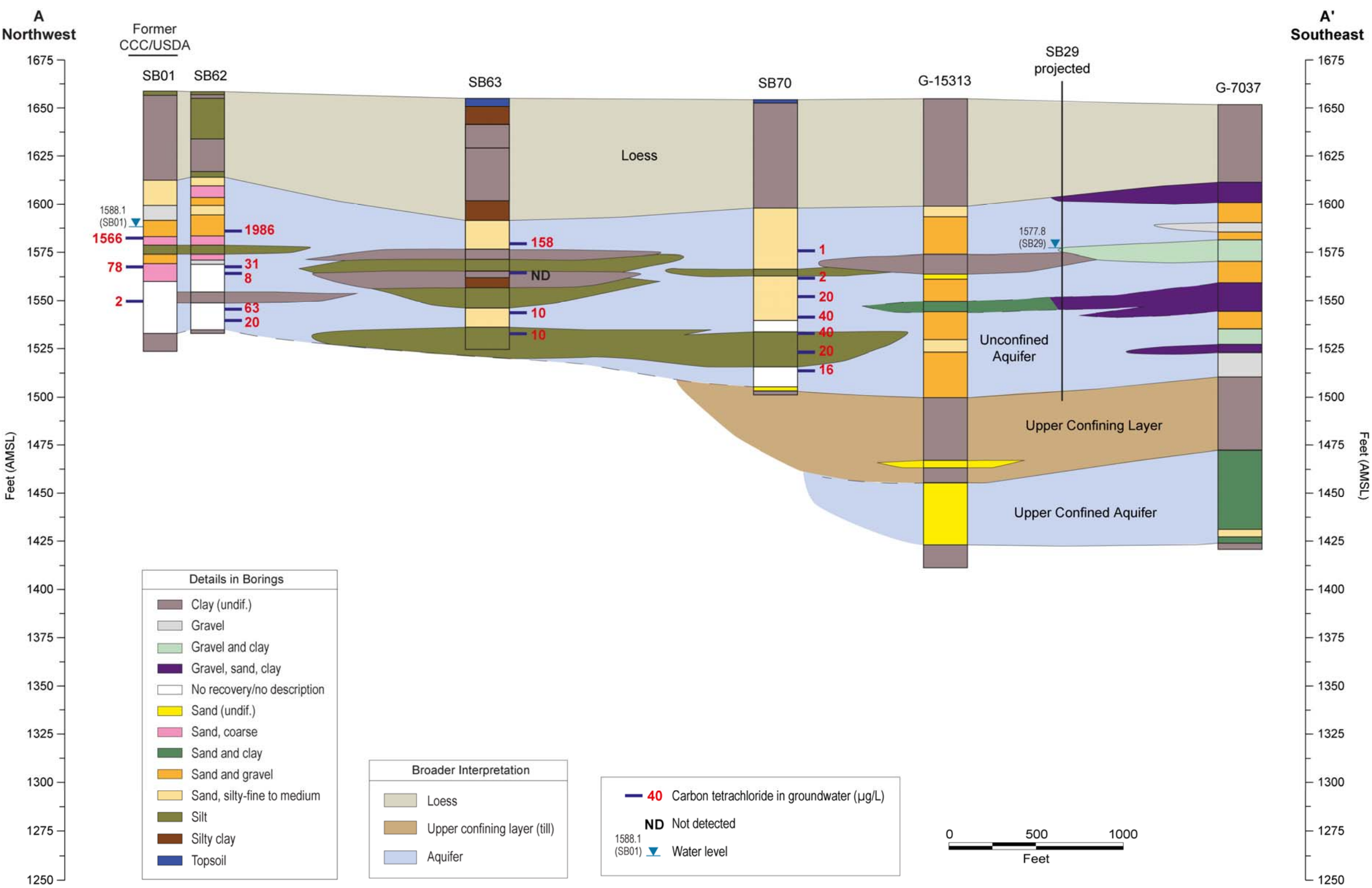

FIGURE 2.16 Northwest-to-southeast geologic cross section A-A'. 


\section{B
Southwest}

G-29841

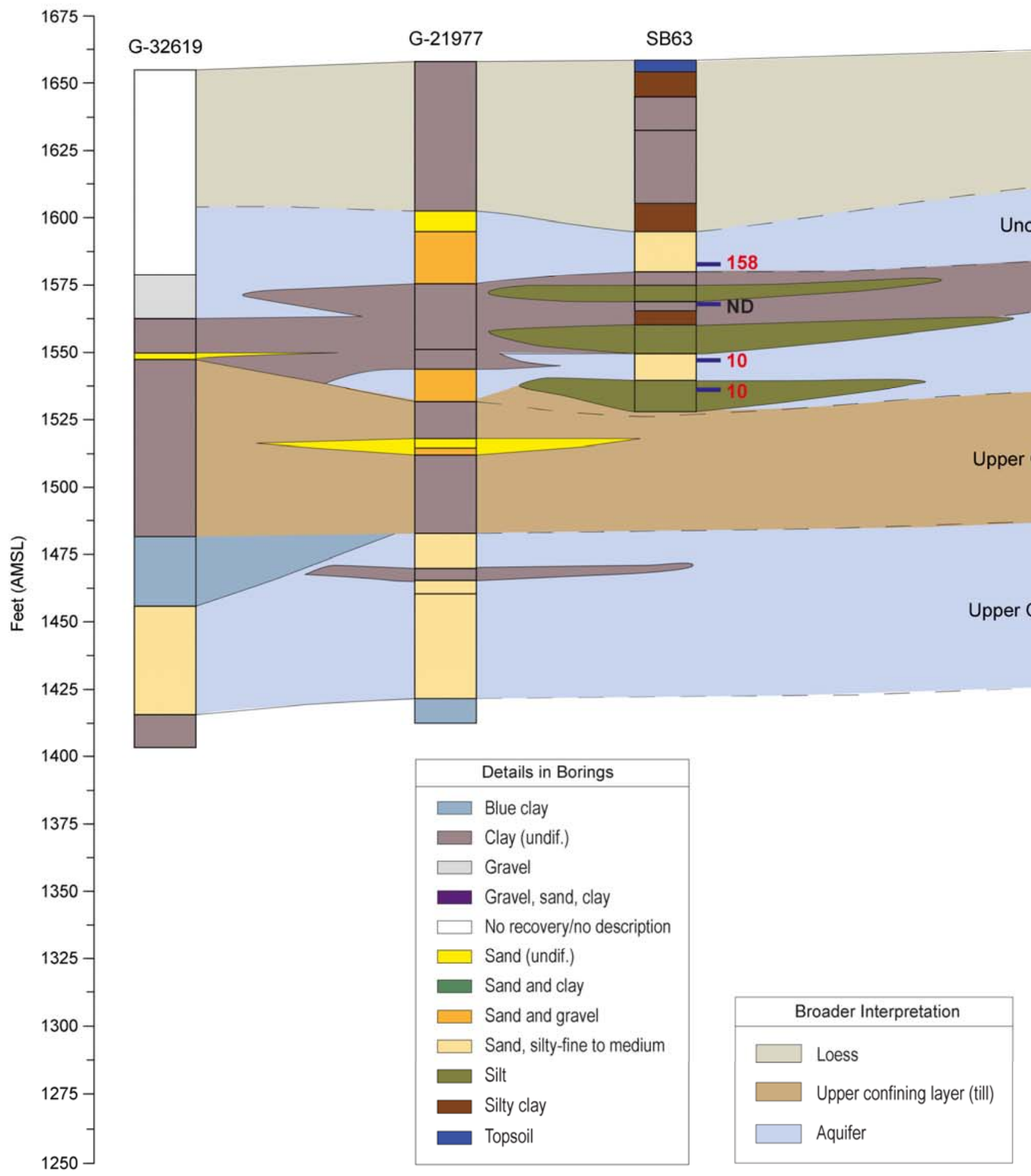

Loess

G-11922 Northeast

1675

nfined Aquife

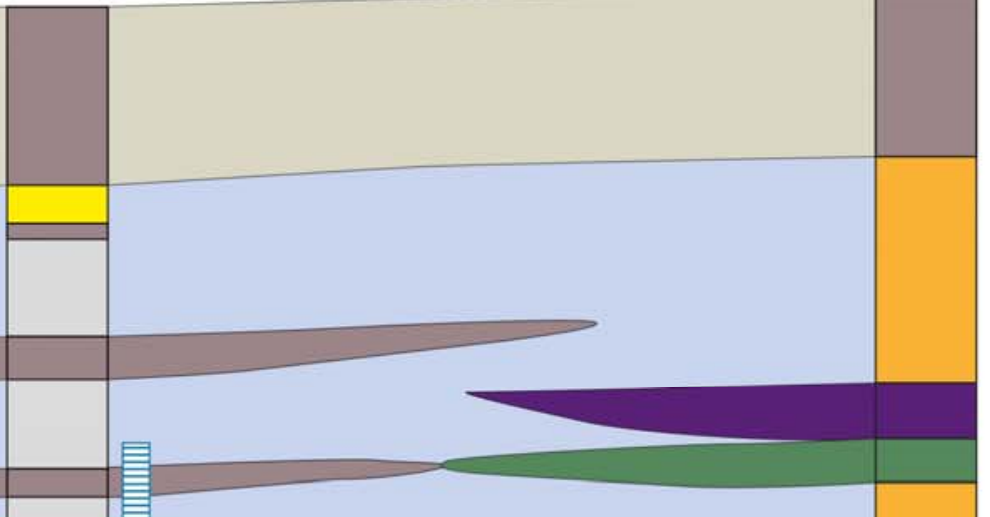

per Confined Aquifer

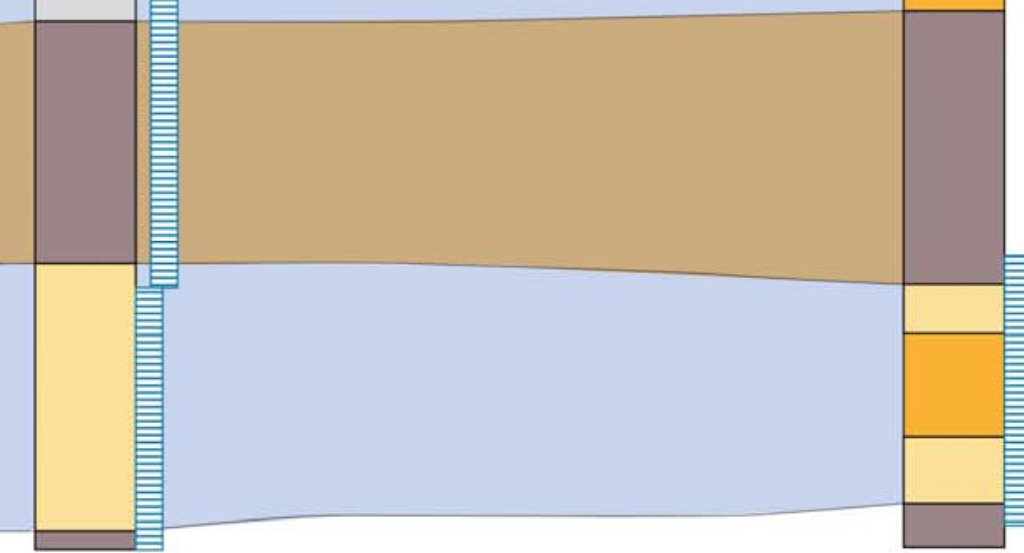

-158 Carbon tetrachloride in groundwater $(\mu g / L)$

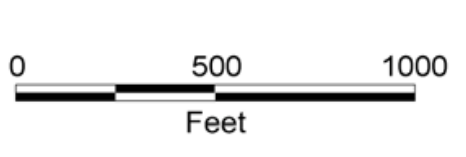

FIGURE 2.17 Southwest-to-northeast geologic cross section B-B'. 


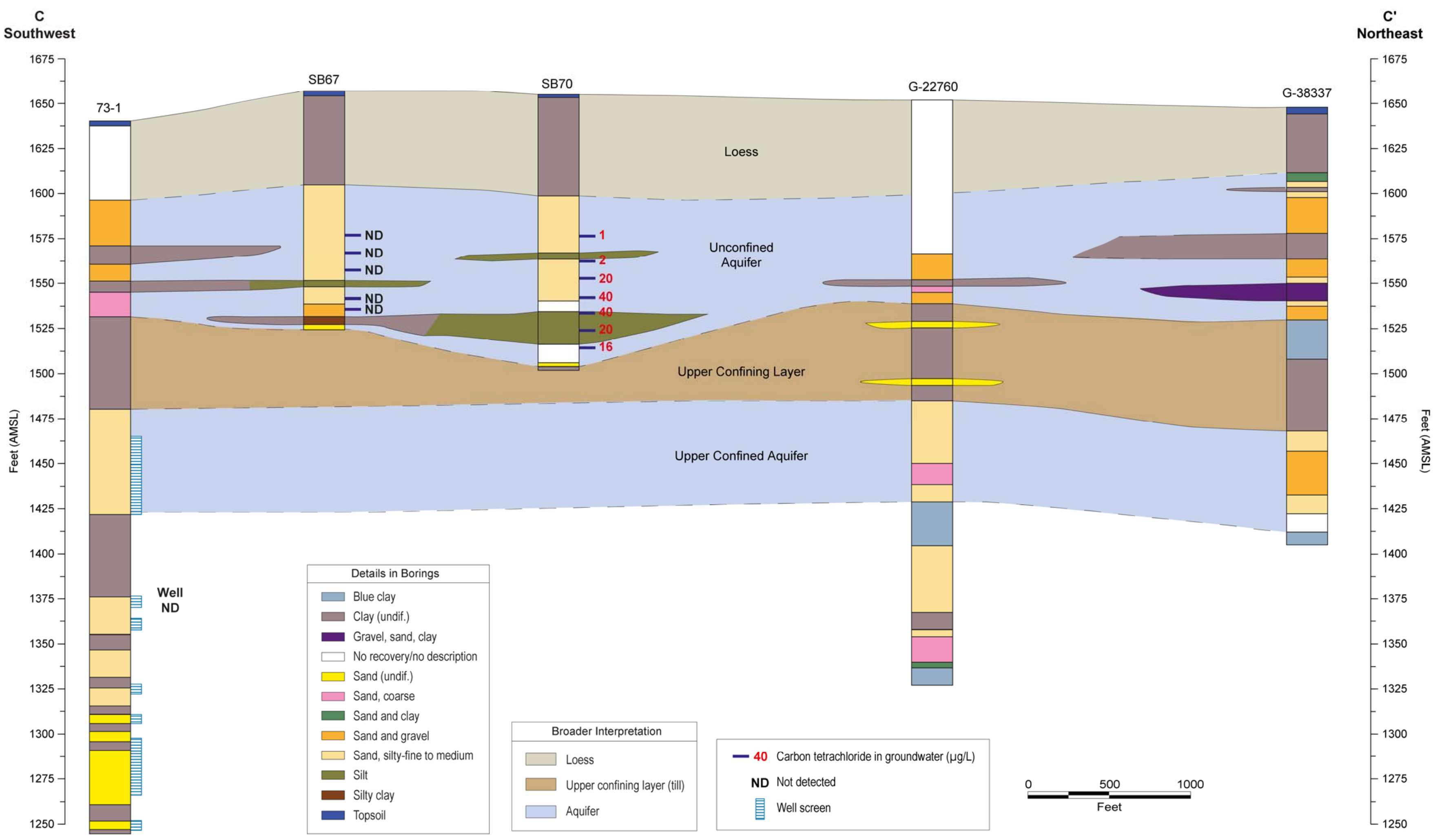

FIGURE 2.18 Southwest-to-northeast geologic cross section C-C'. 

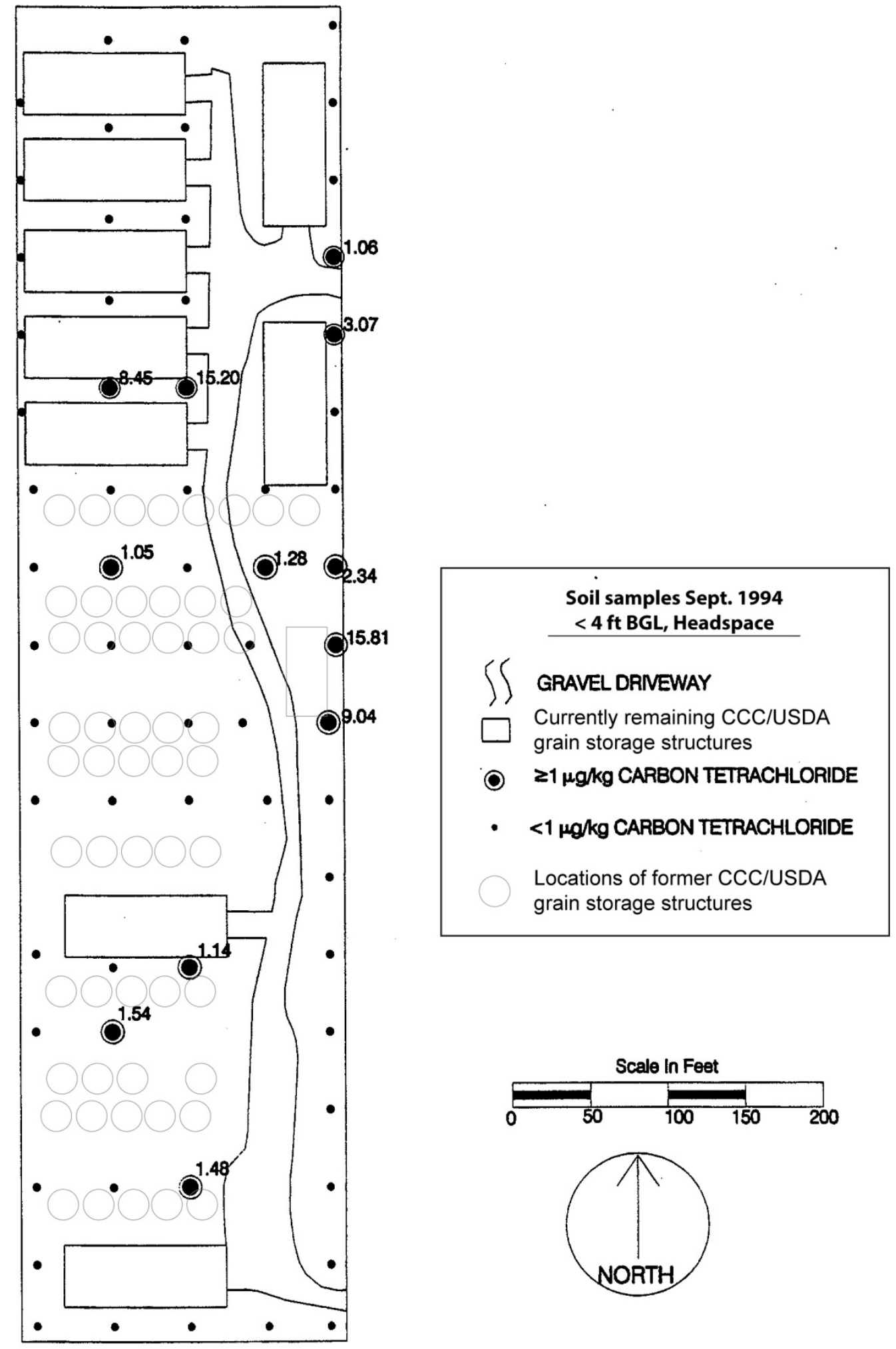

FIGURE 2.19 Carbon tetrachloride concentrations in near-surface soil samples collected in September 1994 at the former CCC/USDA facility, as determined by screening (headspace) analysis (Table 2.2). 


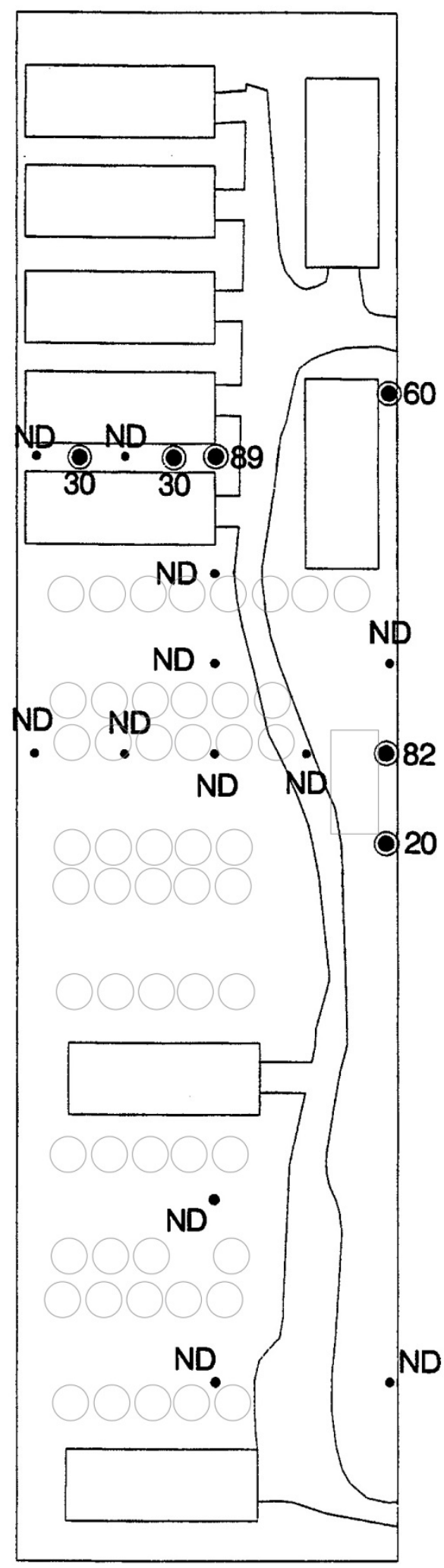

Soil samples Oct. 1994 \& March 1995 < 4 ft BGL, CLP GC-MS

$\iint$ GRAVEL DRIVEWAY

Currently remaining CCC/USDA grain storage structures

-ND NOT DETECTED

O30 $\mu g / k g$ CARBON TETRACHLORIDE

Locations of former CCC/USDA grain storage structures
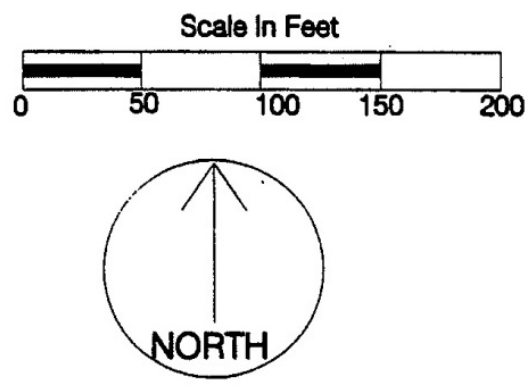

FIGURE 2.20 Carbon tetrachloride concentrations in near-surface soil samples collected in October 1994 and March 1995 at the former CCC/USDA facility, as determined by CLP analysis (Table 2.2 ). 


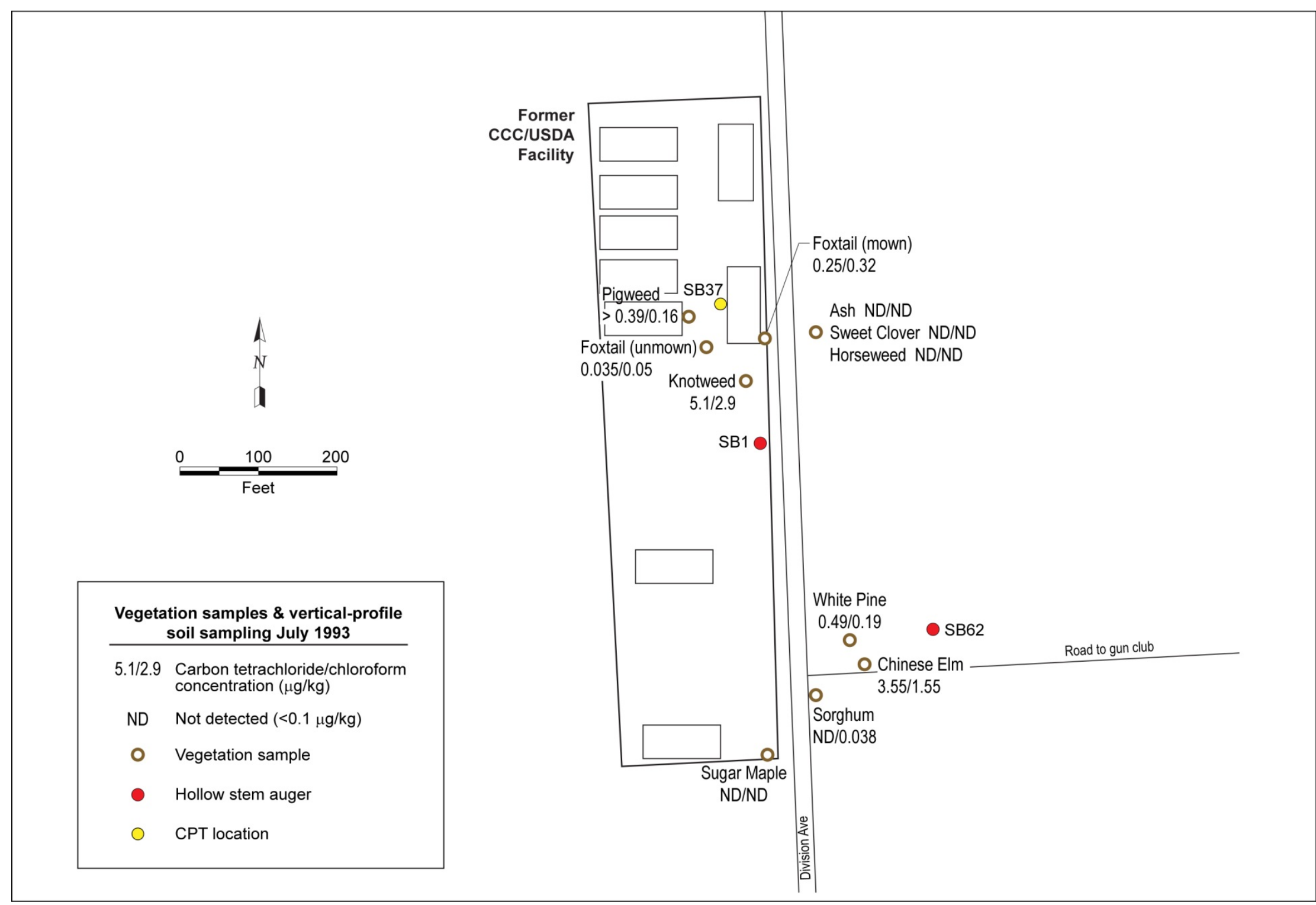

FIGURE 2.21 Carbon tetrachloride and chloroform concentrations in vegetation samples collected in July 1993 at the former CCC/USDA facility and the adjacent Gun Club property, as determined by headspace analysis. 


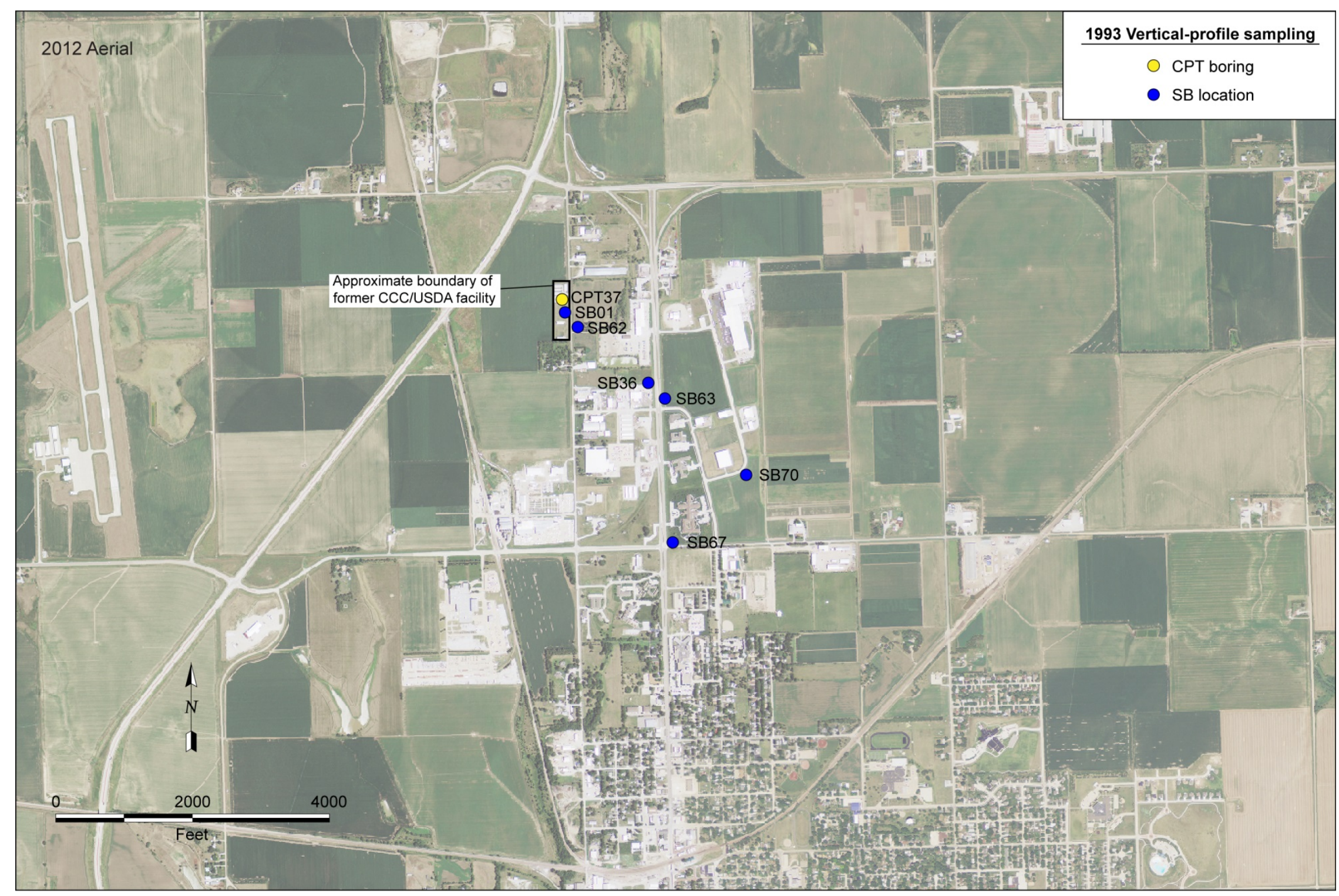

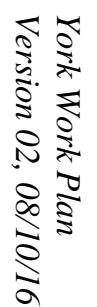

FIGURE 2.22 Approximate locations of vertical-profile soil samples collected in 1993 for VOCs analysis. Source of aerial photograph: USDA (2012). 


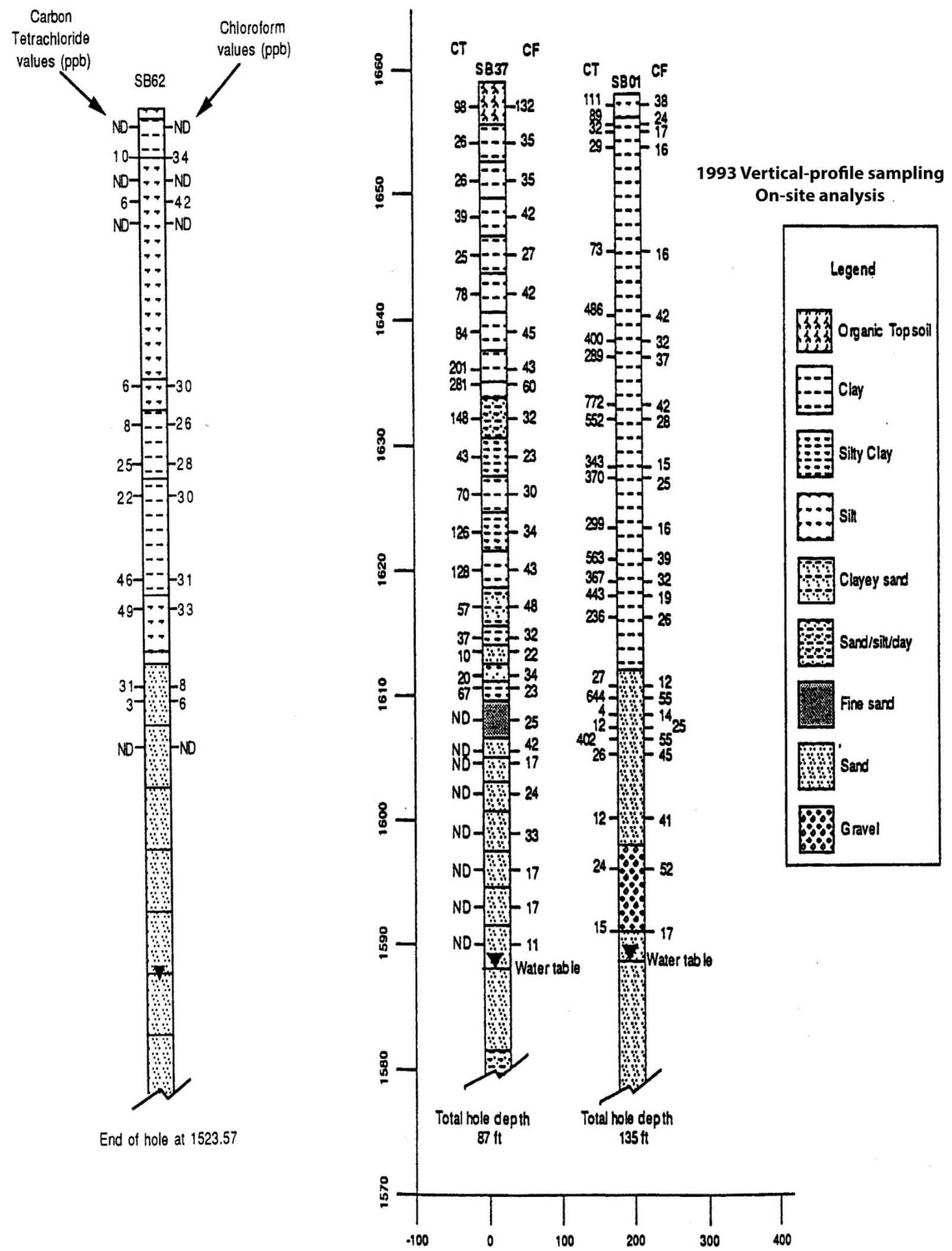

FIGURE 2.23 Vertical distributions of carbon tetrachloride and chloroform $(\mu \mathrm{g} / \mathrm{kg})$ in soils collected in 1993 at investigative borings SB62, SB37, and SB01 (Table 2.3). 


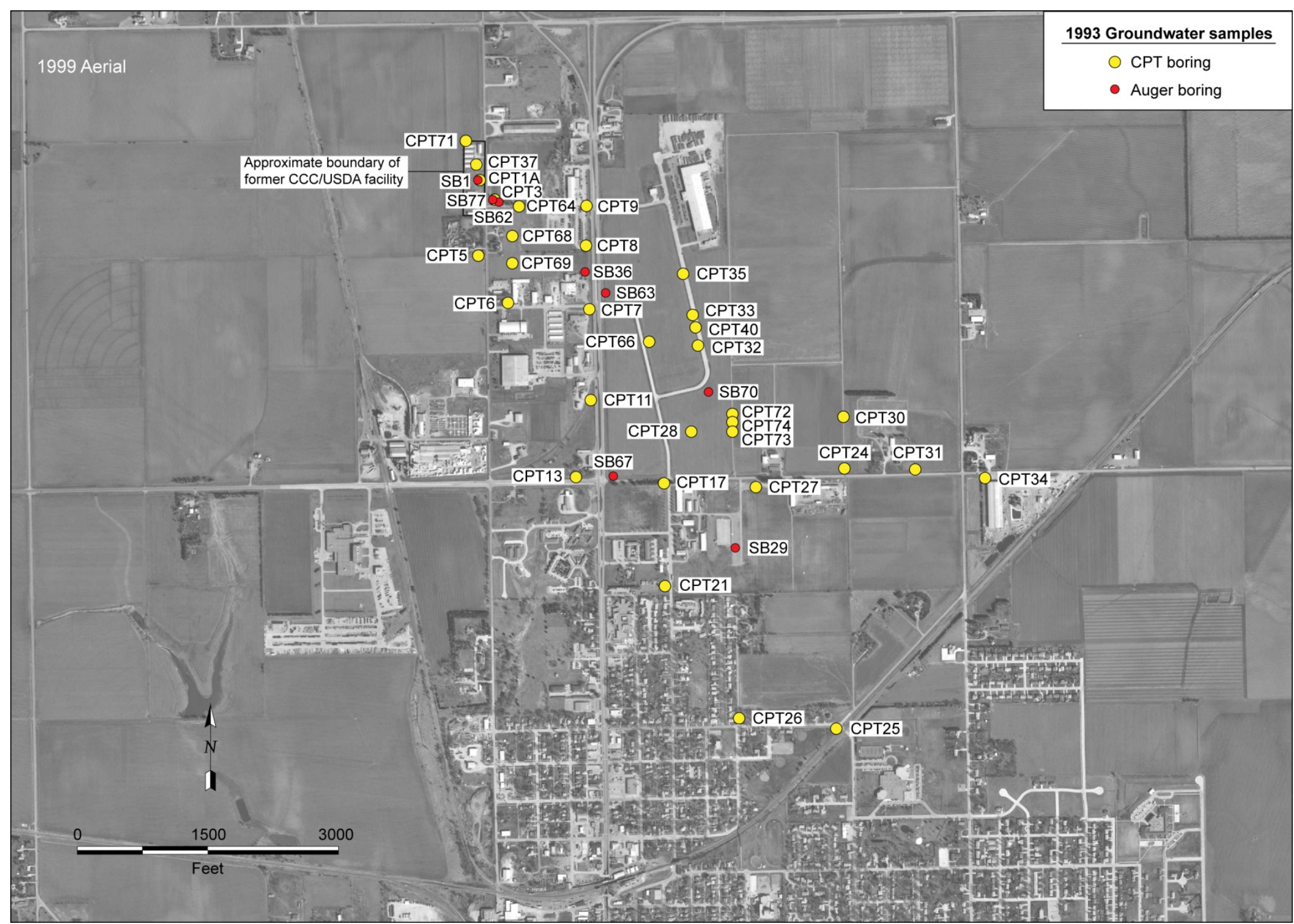

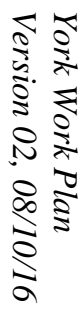

FIGURE 2.24 Approximate locations of the groundwater samples collected from investigative borings in 1993 for VOCs analyses (Table 2.4). Source of aerial photograph: USDA (1999). 


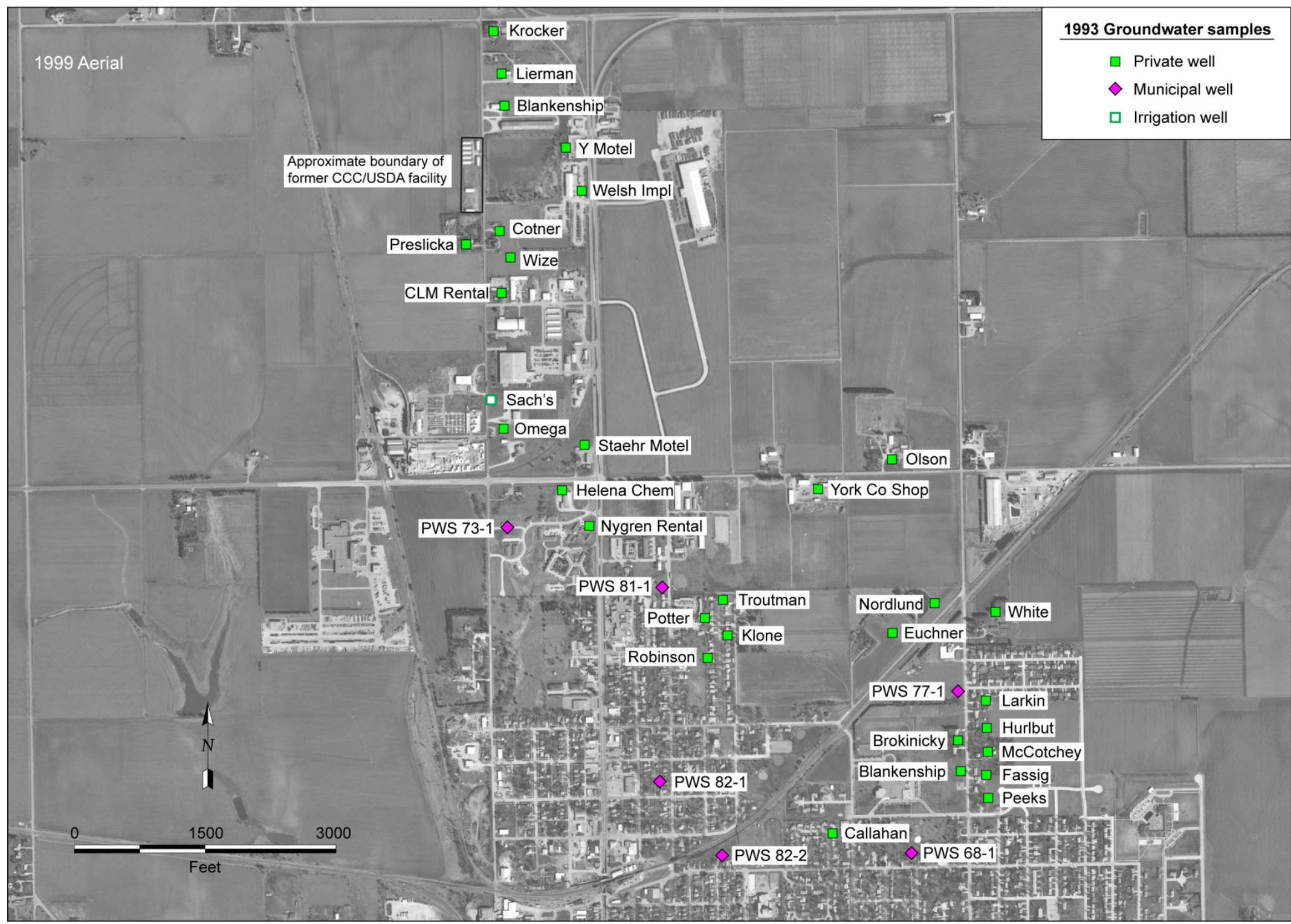

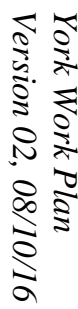

FIGURE 2.25 Approximate locations of groundwater samples collected from private, irrigation, and municipal supply wells in 1993 for VOCs analyses (Table 2.4). Source of aerial photograph: USDA (1999). 


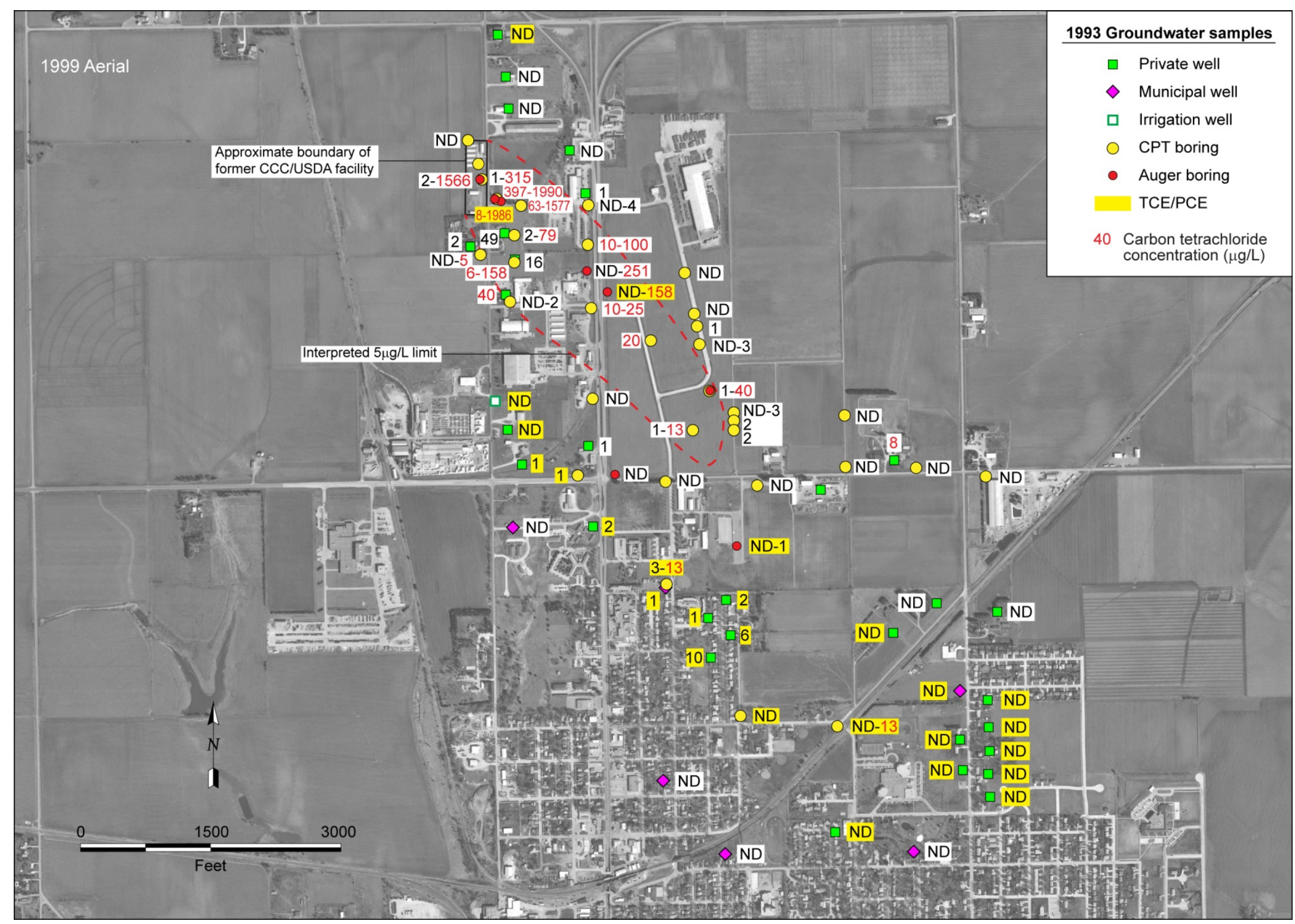

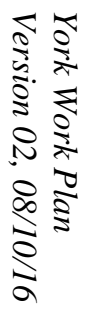

FIGURE 2.26 Lateral distribution of carbon tetrachloride in groundwater samples collected in 1993 (maximum at each location). Source of aerial photograph: USDA (1999). 


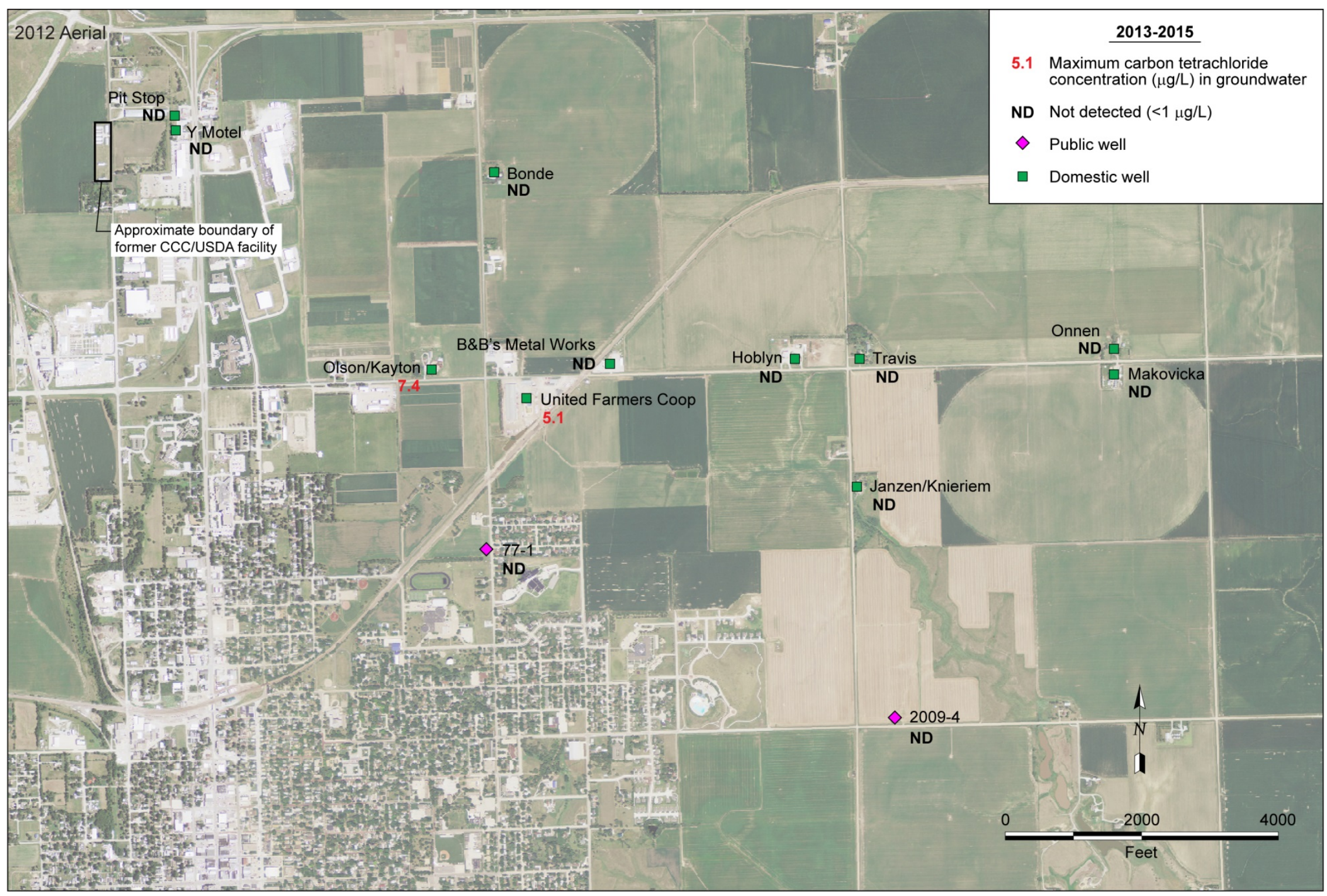

FIGURE 2.27 Carbon tetrachloride concentrations in groundwater samples collected from selected private and municipal supply wells in 20132015. Source of aerial photograph: USDA (2012). 


\section{Proposed Technical Program}

The technical program presented in this section outlines the investigation activities to be conducted by the CCC/USDA at York. As noted in Section 1, the primary objectives of the targeted investigation program, identified in consultation with the CCC/USDA and NDEQ project managers, are as follows:

- Verify the results of the previous investigations for carbon tetrachloride contamination in both soil and groundwater.

- Update the previous findings to determine the present areal and vertical extent and levels of carbon tetrachloride contamination in soil and groundwater.

- Identify any risks that the carbon tetrachloride contamination might pose to currently active private or public wells or to public health via other pathways, including potential vapor intrusion.

To achieve these objectives, five primary tasks will be undertaken in the targeted investigation. These tasks were developed in response to recommendations provided by the NDEQ (2014) and were discussed among representatives of the NDEQ, the CCC/USDA, and Argonne in a meeting held on October 1, 2014. The overall goal is to address specific data gaps identified by the NDEQ in the current understanding of the carbon tetrachloride distribution in soils and groundwater in the vicinity of the former CCC/USDA facility.

The specific activities to be implemented under each task are summarized below. The proposed tasks and investigation locations were selected to accomplish the objectives in a costand time-effective manner. For each task, Argonne will review results as they are received in the field and will consult with the CCC/USDA and NDEQ project managers to ensure that the program is meeting the stated investigation objectives. To this end, the tasks and locations will be subjected to further review and possible modification as the field activities progress, with the consent of the CCC/USDA and NDEQ project managers and subject to property access.

Each task addresses a unique element of the investigative program; however, the tasks do not necessarily define a strict sequence of activities. Although the tasks are presented in a general order of possible completion, for logistic reasons and for efficiency in the field, components of 
one or more tasks might be implemented or be in progress at any time during the on-site investigations.

\subsection{Task 1: Verify the Present Distribution of Carbon Tetrachloride in the Shallow and Deeper (Vadose Zone) Soils at and near the Former CCC/USDA Facility}

As discussed in Section 2.2.2, a screening method (headspace analysis of soils and vegetation) was used in the 1993-1995 site investigation to identify possible areas of carbon tetrachloride contamination in the shallow soils $(\leq 4 \mathrm{ft}$ BGL) at the former CCC/USDA facility. Through interpretation of these screening results, areas of apparent contamination were prioritized for further soil sampling ( $\leq 4 \mathrm{ft}$ BGL) and laboratory analysis with more rigorous CLP methods. In addition, vertical-profile soil sampling revealed carbon tetrachloride contamination, at levels above the current NDEQ VCP target level for this contaminant in soils, at several locations on both the former CCC/USDA property and the adjacent (downgradient) Gun Club property. The potential areal extent of the vadose zone soil contamination beneath these properties was not fully delineated, however, by deep soil sampling and VOCs analyses.

To determine the present distribution of residual carbon tetrachloride contamination in the soils, vertical-profile soil sampling will initially be conducted at locations TI01-TI04 (Figure 3.1), subject to property access. Borings TI01-TI03 will be advanced at the approximate locations of former CCC/USDA borings SB01, SB37/CPT37, and SB62 (Figure 2.22), to provide a basis for direct comparison with the contaminant distribution identified in 1993-1995. At NDEQ (2014) request, boring TI04 will test a location on the Gun Club property, directly east of boring location TI01 (the former SB01). On the basis of the results for these initial borings, further vertical-profile sampling locations will be investigated, as warranted, to determine the areal extent of the present shallow and vadose zone soil contamination. Tentative additional deep soil boring locations are shown in Figure 3.1; however, the specific locations to be investigated will be determined, with the consent of the CCC/USDA and NDEQ project managers, as the results from borings TI01-TI04 are obtained and evaluated.

As noted in Section 2.1.2, the CCC/USDA recently identified a large flat storage structure immediately northeast of the former CCC/USDA facility and north of the Gun Club property. The history of this building suggests that it might formerly have been used by entities other than the CCC/USDA for grain storage. To assess this hypothesis, possible locations for 
vertical-profile soil sampling for VOCs analyses around the building are also suggested in Figure 3.1.

At each of the proposed locations in Figure 3.1, the Argonne 22-ton, track-mounted CPT or the 40-ton, truck-mounted CPT unit will be used to advance the soil boring. Vertical-profile sampling will be performed by recovering continuous soil cores with depth, from the ground surface to the top of the saturated zone (the water table, anticipated at roughly 70-80 $\mathrm{ft}$ BGL). Soil aliquots for VOCs analyses will be recovered from the cores at approximately 4-ft intervals, in accord with the procedures in Section 4.1. If initial efforts to penetrate the unconsolidated sequence with the CPT unit(s) to the required depths (see also Section 3.3) prove unsuccessful, Argonne will consult with the CCC/USDA and NDEQ project managers and make arrangements for potential continuation of the field program with a conventional (sonic) drilling rig.

\subsection{Task 2: Determine the Potential Levels of VOCs Contamination in Soil Vapor at/near the Former CCC/USDA Facility}

To determine the possible risk of vapor intrusion that might be associated with residual carbon tetrachloride levels identified in the (unsaturated) soils at/near the former CCC/USDA facility, soil vapor samples will be collected at the two Task 1 soil boring locations (Figure 3.1) that return the highest current levels of subsurface soil contamination. The soil gas samples will be collected at depths of 6.5-7 ft BGL (i.e., basement level) and will be analyzed for VOCs by using the procedures in Section 4.2.

\subsection{Task 3: Determine the Current Areal and Vertical Extent of Carbon Tetrachloride Contamination in the Unconfined Aquifer Groundwater Downgradient from the Former CCC/USDA Facility and Establish Permanent Groundwater Monitoring Points}

The CCC/USDA sampling in 1993 (Section 2.2.3) identified carbon tetrachloride (and lesser chloroform) contamination in the groundwater of the unconfined aquifer, extending an approximate distance of 4,000 ft downgradient of the former CCC/USDA facility and the Gun Club property. At most investigated locations, higher contaminant levels were generally detected in the uppermost portions of the (unconfined) aquifer; however, contamination was also identified at depths ranging from just below the water table to the base of the aquifer at multiple locations. 
To determine the present distribution of carbon tetrachloride and its potential degradation products in the unconfined aquifer, groundwater sampling for VOCs analyses will be performed (1) at selected locations and depths examined in the previous CCC/USDA investigation, for comparison with the earlier results, and (2) at additional new locations, as warranted, to evaluate the areal and vertical extent of these compounds in groundwater under the current hydrologic conditions. Suggested initial points (both existing private wells and proposed investigative borings) for this groundwater sampling are shown in Figure 3.2. Included are locations around the flat storage building discussed in Section 3.1. The actual number of locations and specific depth intervals to be sampled as part of this task will be determined as the results of the investigation are progressively obtained and reviewed.

For locations in Figure 3.2 that were sampled for groundwater in 1993, the wells and boring depth intervals formerly tested will guide the current sampling strategy. At new locations, subsurface information required to characterize the local lithologic sequence will first be obtained by continuously coring the unconsolidated profile to the base of the unconfined aquifer at boring TI01 and at least one additional, more downgradient location. The cores will be examined visually to evaluate lithology and identify the characteristics of the permeable units. These data will provide a basis for correlation of the primary lithologic types with corresponding geomechanical log responses (tip pressure, sleeve friction, conductivity [if possible], and tipversus-sleeve ratio) obtained with the CPT unit(s). This approach proved successful during the earlier investigations and demonstrated that electronic CPT logging at subsequent investigation locations could identify predominantly coarse-grained versus fine-grained deposits and hence guide the selection of depth intervals for groundwater sampling. Supplemental continuous or selective coring with depth might also be performed at individual locations, as necessary, to establish or confirm the site-specific lithologic sequence. At each new boring location, efforts will be made to recover groundwater samples near the top, middle, and base of the unconfined aquifer, if the materials are sufficiently permeable.

As logistically possible, the proposed groundwater sampling will be conducted by using the direct-push capabilities of the CPT vehicle(s) in accord with the sampling procedures described in Section 4.3.1. If the specific technical objectives of this task cannot be achieved via this approach, Argonne will consult with the CCC/USDA and NDEQ project managers and make arrangements to continue groundwater sampling with a conventional (sonic) drilling rig. If the use of a drilling rig is required, groundwater sampling will be performed as outlined in Section 4.3.2. 
All groundwater samples recovered during the proposed investigation will be analyzed for a full suite of VOCs (to include carbon tetrachloride, chloroform, methylene chloride, chloromethane, TCE, PCE, and 1,1-DCE), as described in Section 4.3.3.

The results of this task will be compiled and reviewed with the CCC/USDA and NDEQ project managers as the groundwater sampling progresses. On the basis of these findings, and in consultation with the project managers, locations will be identified for the construction of permanent groundwater monitoring wells penetrating the unconfined aquifer unit, to be installed with a conventional (sonic) drilling rig as described in Section 4.5.

As discussed in Section 3.5, the installation of permanent monitoring wells is anticipated in the deeper confined aquifer(s) in the vicinity of the former CCC/USDA facility as part of Task 5 of this investigation.

The exact number of wells and their specific locations cannot be determined at this time. The wells will be sited, however, to (1) facilitate continued observation of the identified areas of highest contamination, (2) provide a network for measurement and recording (with automated water level sensing units; Section 4.6) of local groundwater levels and hence determining groundwater flow direction(s), and (3) provide a basis for assessing potential future migration of the identified groundwater contamination.

Detailed recommendations for the installation of drilled permanent monitoring wells will be provided for CCC/USDA and NDEQ review and approval as the targeted investigation progresses. To address this need in the most time- and cost-efficient manner, well installation will be coordinated with the deeper (confined) aquifer investigation activities discussed in Task 5, Section 3.5.

\subsection{Task 4: Update the Inventory and Status of Private Wells in the Targeted Investigation Area}

Figures 2.25 and 2.26 show numerous private wells that were identified near and downgradient of the former CCC/USDA facility in 1993 and were sampled for VOCs analyses at that time. Figure 3.2 illustrates the private wells selected for sampling in Task 3 of the current study, if these wells are still in service and access for sampling can be obtained. 
As Task 4, the CCC/USDA will supplement Task 3 by performing a public records search and, as necessary, conducting on-site surveys to determine the status and usage of private wells in the targeted investigation area, particularly to identify any recently installed private wells not shown in Figure 3.2. At the specific request of the NDEQ, any previously unsampled drinking water wells that might be identified in this area will be sampled for VOCs analyses as part of Task 3.

\subsection{Task 5: Investigate for Possible Carbon Tetrachloride Contamination of the Deeper (Confined) Aquifer(s)}

Groundwater sampling and analyses in 1993 demonstrated that carbon tetrachloride contamination in the vicinity of the former CCC/USDA facility had penetrated to the base of the unconfined aquifer, strongly suggesting that the thin, interbedded, silt-clay horizons locally identified in the aquifer do not preclude vertical migration of groundwater and contaminants. In contrast, USGS studies have generally concluded that the thicker, regionally developed clay-till upper confining unit underlying the unconfined aquifer represents a lithologically competent barrier to vertical migration (Keech et al. 1967; Landon and Turco 2007; Clark et al. 2008; Landon et al. 2008). The USGS studies have also determined, however, that penetration of the upper confining unit by numerous deep, multiply screened (or continuously sand-packed) private, irrigation, and public water supply wells in the vicinity of York might provide artificial conduits for the movement of groundwater and contaminants into the underlying upper and lower confined aquifers. Data for the York public wells (Table 2.1) indicate that these wells are variably screened to a maximum depth of $394 \mathrm{ft} \mathrm{BGL}$.

To investigate for possible carbon tetrachloride contamination in the confined aquifer(s) in the immediate vicinity of the former CCC/USDA facility, two deep borings (drilled with a sonic rig) are proposed, at locations to be determined on the basis of the targeted investigation results. One boring will be advanced at or slightly downgradient of the location having the maximum carbon tetrachloride concentration identified in the unconfined aquifer groundwater in Task 3 (Section 3.3 and Figure 3.2). The second deep boring will be sited at or slightly beyond the downgradient toe of the carbon tetrachloride contamination identified in the proposed targeted investigation in the unconfined aquifer groundwater.

At each deep drilling location, the investigative boring will be cored continuously through the full thickness of the unconfined aquifer, the upper confining layer, and the upper 
confined aquifer, to facilitate groundwater sampling for VOCs analyses from this unit. If the results of these analyses indicate that sampling of the deeper groundwater for VOCs analysis is technically warranted, the boring will be advanced further to permit groundwater sampling at a depth range comparable to that of the first (shallowest) screened interval in the lower confined aquifer identified in the nearest active, downgradient public water supply well(s). Table 2.1 indicates that these screened intervals are typically at depths of approximately 260-280 $\mathrm{ft}$ BGL. Additional locations for possible deep borings and depths for groundwater sampling will be considered, if technically warranted, in consultation with the CCC/USDA and NDEQ project managers as the results of Tasks 1-4 become available.

At each selected depth interval in the deep borings, groundwater will be sampled by using the methods described in Section 4.3.2. A permanent monitoring well will also be installed at each deep boring location, in accord with the methods presented in Section 4.5 and all applicable NDEQ requirements. 


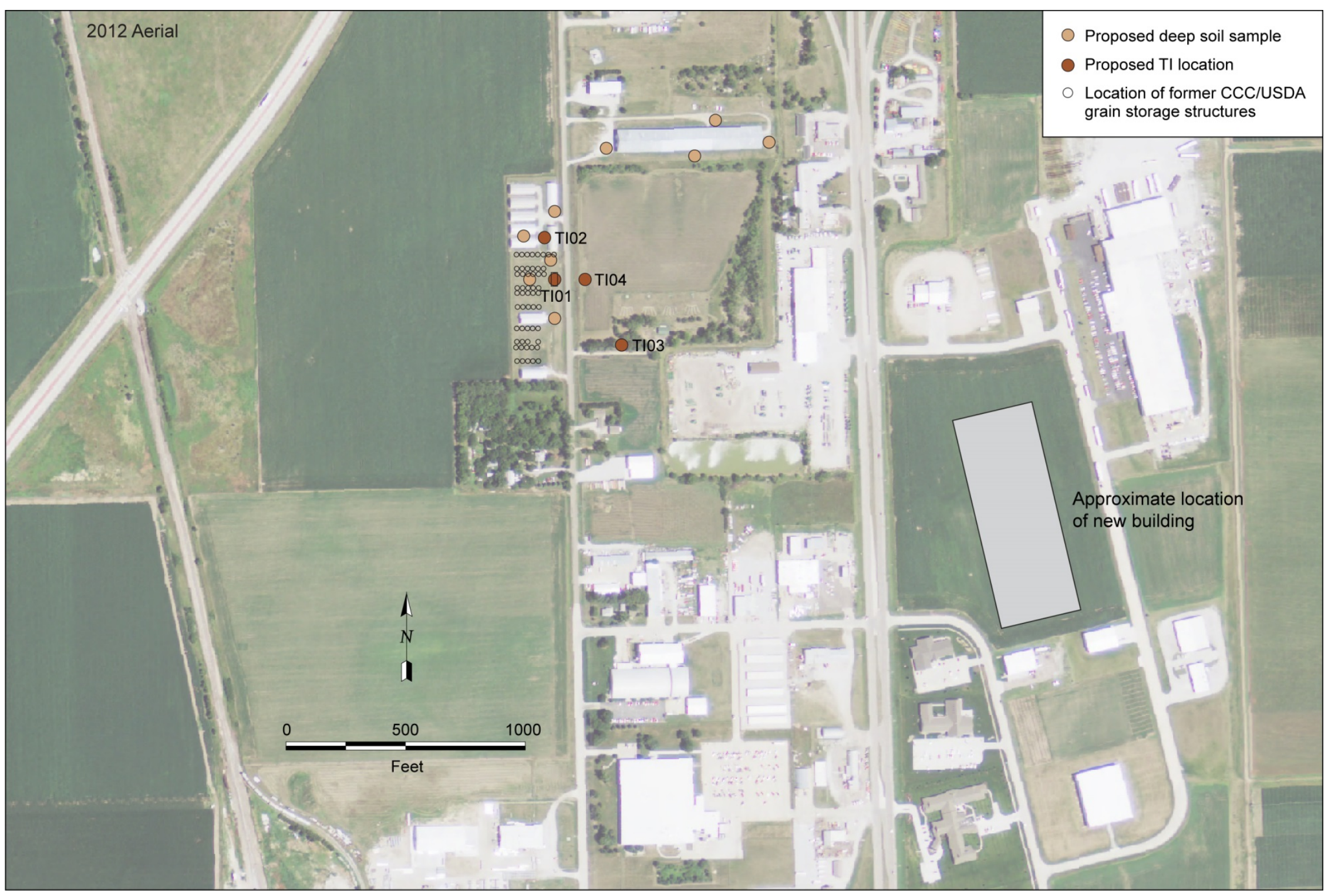

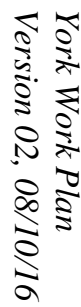

FIGURE 3.1 Recommended locations for deep soil sampling for VOCs analyses. Source of aerial photograph: USDA (2012). 


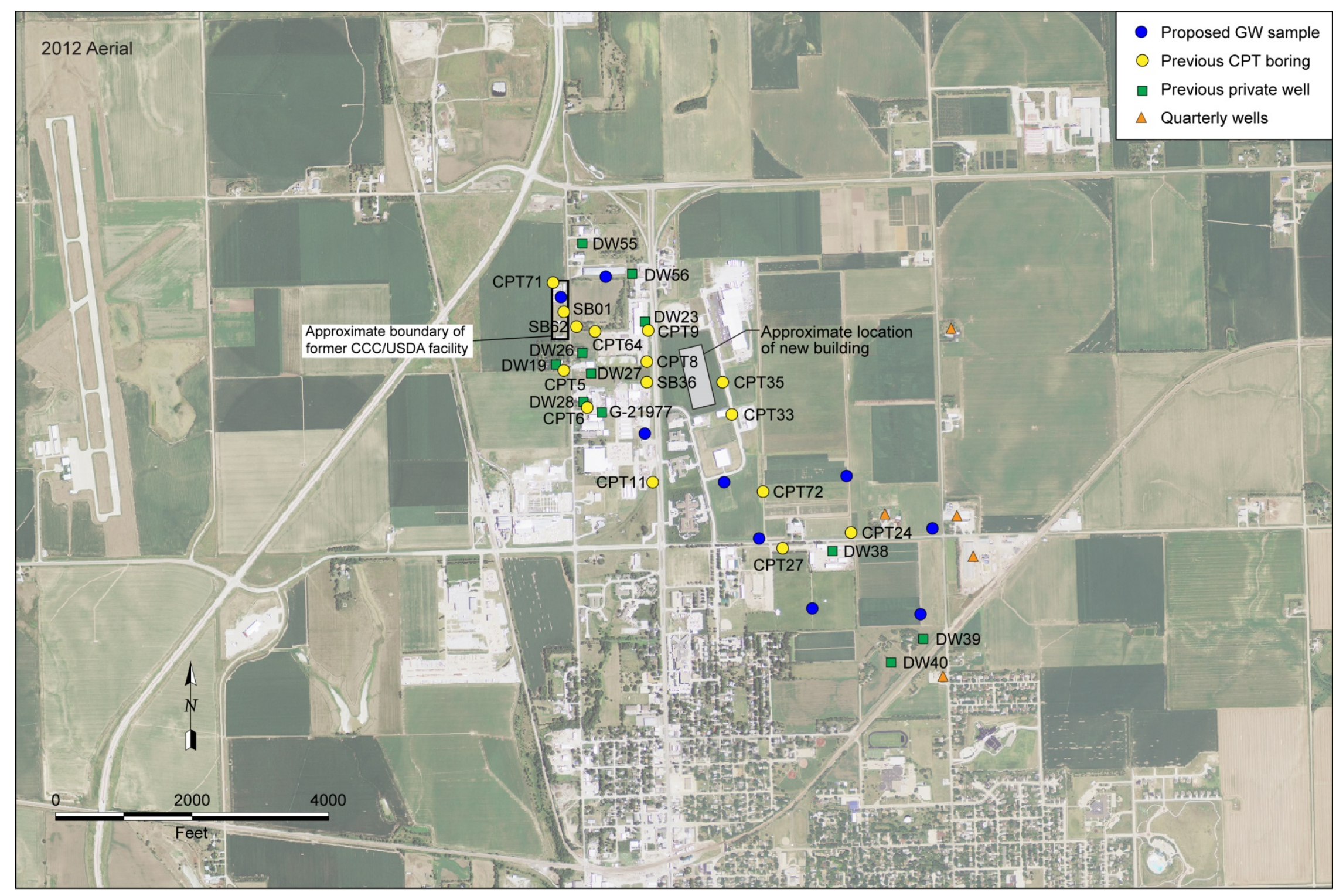

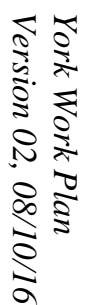

FIGURE 3.2 Recommended locations for groundwater sampling for VOCs analyses. Source of aerial photograph: USDA (2012). 


\section{Investigative Methods}

The site-specific technologies, field procedures, and analytical methods used to address the investigation tasks presented in Section 3 are discussed below. Argonne will implement the recommended tasks in accord with established standard operating procedures, relevant state regulations, quality assurance/quality control $(\mathrm{QA} / \mathrm{QC})$ measures, and general health and safety policies.

\subsection{Methods for Soil Coring, Sampling, and Analysis}

Soil cores for lithologic determination and/or collection of soil samples for VOCs analyses will be recovered by using the CPT units or a sonic drilling rig. All cores will be examined visually and logged in accord with procedures described in the Master Work Plan (Argonne 2002) and will be archived at an Argonne facility upon completion of the field program for future reference. At selected locations and depth intervals, soil samples might also be collected from the cores for soil property testing (e.g., moisture content, porosity, bulk density), grain size analysis, or other analyses (total organic carbon content, etc.).

Coring with the CPT units will be performed by advancing a 4-ft-long core barrel equipped with a 1.125-in.-ID disposable liner (Geoprobe dual-tube coring system). Soil samples for VOCs analyses will be obtained from the cores at 4-ft intervals to the depth of the water table as encountered at the time of the investigation, as well as to capture any unique changes in lithologic characteristics with depth. The samples for VOCs analyses will be removed immediately from the core by cutting through the disposable liner at the selected interval(s).

To obtain cores with the sonic drilling rig, an inner drill string and core barrel will be advanced $5 \mathrm{ft}$ or $10 \mathrm{ft}$ at a time, followed by advancement of an outer override casing to seal the upper portion of the borehole. The inner barrel will then be retracted, and the core will be removed for sampling at the required vertical intervals.

Soil samples for VOCs analyses recovered by either coring method will be placed immediately in jars, then sealed and placed in coolers with dry ice at $-78.5^{\circ} \mathrm{C}$ for overnight shipment to the Applied Geosciences and Environmental Management (AGEM) Laboratory at Argonne for rapid-turnaround analysis. The samples will be analyzed initially by a screening headspace method on a GC-ECD system (modified EPA Method 5021). The results of these 
analyses will be provided to the field personnel, strictly as a qualitative indication of potential contaminant presence and relative levels that might be useful in guiding further sampling efforts. All soil samples will subsequently be analyzed by a purge-and-trap sample preparation method with analysis for VOCs on a GC-MS system (EPA Methods 5030B and 8260B), for quantitative determination of contaminant levels.

Soil cores collected during sampling will be retained in core boxes for lithologic description and research. The cores will be transported to and stored at an Argonne facility for further reference.

\subsection{Methods for Soil Gas Sampling and Analysis}

Soil gas samples will be collected by using the CPT unit or a small Geoprobe with a Post Run Tubing (PRT) system. Prior to boring, an expendable point holder will be attached to the lead push rod within the rod bore, and an O-ring will be used to place an expendable point in the holder. The rod string will be advanced to a depth of $7 \mathrm{ft}(213 \mathrm{~cm})$ BGL. The stainless steel PRT adapter with the attached tubing will be inserted and lowered to the bottom of the rod bore. The top end of the tube will be sealed to minimize gas exchange with ambient air. The PRT adapter will be threaded into the reverse-thread fitting at the top of the expendable point holder by manually rotating the tubing counterclockwise until the O-ring on the adapter is sealed against the point holder. The rod string will be retracted back to $6 \mathrm{ft}(183 \mathrm{~cm})$ BGL, exposing a 1-ft interval of the soils for sampling. To remove the residual air in the system, the tubing will be purged before sample collection. A soil gas sample will then be withdrawn through the tubing into a metal, certified-clean 1-L gas canister.

The soil gas samples will be shipped immediately to TestAmerica for VOCs analysis with EPA Method TO-15. 


\subsection{Methods for Groundwater Sampling and Analysis}

\subsubsection{Groundwater Sampling with the Cone Penetrometer}

At each CPT groundwater sampling point (Section 3.3), the CPT rods will be used to push a sacrificial tip and 0.5-in.-ID polyvinyl chloride (PVC) filter screen and riser to the desired maximum sampling depth. The rods will then be partially withdrawn to the desired upper sampling depth, to expose the screen to the formation waters. Water samples will be collected from the PVC casing by using a bailer, without purging, for preservation and analysis as described in Section 4.3.3.

\subsubsection{Groundwater Sampling with the Drilling Rig}

Groundwater samples will be collected with the sonic drilling rig by using one of the two methods below.

Groundwater samples can be collected directly as the sonic boring is being advanced, either by using a bailer (without purging) or after purging with a submersible pump. In either case, the sample is retrieved from the portion of the borehole that is exposed to the formation between the bottom of the overriding (outer) casing and the bottom of the borehole. As the boring is progressively advanced in 5-ft or 10-ft increments, the override casing is also advanced, so that the upper portion of the borehole remains continuously sealed.

If groundwater sampling from the sonic borehole is required after drilling to depth has been completed, a packer-and-riser technique for placing a pair of packers on steel piping (a work string) in the borehole can be used for discrete groundwater sampling in target zone(s) of interest. With this technique, a straddle packer assembly is lowered into the borehole (without override casing) to the desired depth. The pair of packers is then inflated, so that groundwater samples can be collected from the interval between the two packers. Once the groundwater sampling is complete, the packers can be deflated, then moved and re-inflated to sample additional zone(s) of interest. 


\subsubsection{Sample Preservation and Analysis}

All groundwater samples collected in the targeted investigation will be preserved on ice at $4^{\circ} \mathrm{C}$ and shipped overnight to the AGEM Laboratory for rapid-turnaround (24-hr) analysis.

Water samples will be analyzed by the purge-and-trap method on a GC-MS system (EPA Methods 5030B and 8260B). To ensure reproducibility, a minimum of $10 \%$ of the water samples will be selected for verification analysis by a second laboratory (TestAmerica) with the EPA's CLP methods. An index to the EPA methods is online (http://www.epa.gov/epahome/index/).

\subsection{Decontamination}

To ensure the integrity of the media sampled for laboratory analysis at each sampling point, a hot-water pressure washer will be used to decontaminate the CPT and drilling rig, tools, and equipment, as needed.

\subsection{Methods for Installing Monitoring Wells and Abandoning Boreholes}

Monitoring wells will be installed with a sonic drilling rig. The wells will consist of 2-in. PVC casing installed in 6.25-in.-diameter boreholes. Screens will be 0.010 -in. mill slot PVC, at lengths appropriate for the chosen depth intervals. A filter pack will installed to $2 \mathrm{ft}$ above the screened interval, with a $2-\mathrm{ft}$ to 5 - $\mathrm{ft}$ bentonite pellet seal above the filter pack. A tremie pipe will be used to seal the remainder of the hole with a high-solids bentonite grout slurry, from the top of the bentonite seal to within $3 \mathrm{ft}$ of the ground surface. The surface will be completed with a 12-in. flush-mount well cover or an above-ground (stick-up) protective casing cemented in place, at the discretion of each property owner. The top of the casing will be fitted with a 2-in. locking J-plug.

All wells will be constructed in accord with Nebraska guidelines (Title 178 NAC 12). Completed wells will be registered with the state. Any variances required will be obtained from the appropriate agency prior to installation. All investigation-derived waste (IDW) will be managed as described in Section 4.7. After installation, each well will be pumped and developed for a minimum of $2 \mathrm{hr}$, or as determined by the attendant drilling engineer to be necessary. 
All CPT investigation boreholes and all drilled boreholes that are not selected for completion as monitoring wells will be abandoned according to Nebraska requirements (Title 178 NAC 12).

\subsection{Methods for Water Level Monitoring}

Groundwater levels will be monitored continuously in the installed monitoring wells, as well as in any pre-existing monitoring or other wells in the study area that might be identified as suitable for this purpose (subject to access), by using programmable downhole pressure sensors and data loggers (Instrumentation Northwest AquiStar PT2X ${ }^{\mathrm{TM}}$ devices). The data logger at each location will be programmed initially to record one measurement every $30 \mathrm{~min}$. The data from the loggers will be downloaded after approximately one month of operation, and the resulting hydrographs will be examined for possible evidence of pumping effects associated with the York public water supply wells and/or nearby private wells, as well as other short-term variations in the local groundwater levels. On the basis of these results, monitoring will either continue at the original measurement frequency, or the loggers will be reprogrammed to a recording interval suitable for extended monitoring. To document possible variations in responses to the pumping of wells and also seasonal or other longer-term potential influences on the local groundwater levels, the automated monitoring will continue for at least 12 months.

To confirm that the sensors and loggers are performing appropriately, groundwater levels will also be measured manually in all monitoring wells at each data logger downloading event.

\subsection{Methods for Handling and Disposal of Investigation-Derived Waste}

The approach to handling and disposal of soil and water IDW will be as follows:

- Soil IDW from drilling activities will be stored on-site in 55-gal drums or a roll-off container. A representative sample will be collected and analyzed for VOCs by the AGEM Laboratory and for TCLP (toxicity characteristic leaching procedure) volatiles by TestAmerica.

- A Solid Waste Disposal Authorization will be obtained from the NDEQ for disposal of soil in a permitted landfill. If analytical data indicate that the soils 
cannot be placed in a permitted landfill, alternative disposal methods will be proposed to the NDEQ for review.

- Water IDW will be stored on-site in 55-gal drums or polyurethane containers. All containers will be covered and stored on the site prior to disposal. The wastewater will be analyzed for VOCs by the AGEM Laboratory.

- If analytical results for the wastewater indicate concentrations of carbon tetrachloride, chloroform, and methylene chloride below the MCLs, then the water will be discharged on-site, away from known sensitive receptors. If the analytical results indicate concentrations above the MCLs, then the water will be disposed of at a wastewater treatment facility approved by the NDEQ.

\subsection{Quality Assurance/Quality Control for Sampling and Analysis}

Quality in sampling and analysis will be assured through documentation of activities, performance and system audits, and periodic evaluations of QC procedures. The project QA/QC requirements will be satisfied through periodic and final reviews covering all aspects of sampling, field measurements, chemical analyses, data collection, data reporting, instrument calibrations, routine maintenance of analytical equipment, and standardization procedures in analyses. In addition, technical review of the results will ensure that the stated objectives of the project are met.

Conditions significantly adverse to quality, their causes, and corrective actions taken will be documented and reported to the technical project manager, the QA/QC coordinator, and the AGEM program manager. Examples of such conditions are deficiencies in the use of procedures or instructions, failure to implement corrective actions in response to nonconformances with quality standards, and unexpected loss of or damage to documentation. Corrective action will be implemented in a timely manner, and the field team will be informed of the issue. Actions taken to correct problems or deficiencies during sampling in the field or during laboratory analyses will be documented and described in the QA portion of the sampling and analysis report. 


\subsubsection{Field Quality Assurance/Quality Control for Sampling and Analysis}

\subsubsection{Sample Collection}

The following two major criteria must be met in sampling:

1. The samples must be a genuine representation of the conditions prevalent at the site.

2. Adequate numbers of samples must be available for meaningful characterization or monitoring of the site, in the judgment of the technical project manager and the AGEM program manager and with the concurrence of the CCC/USDA and NDEQ project managers.

In some cases, it might not be possible to collect samples from an intended location because of access constraints. In such cases, alternate or additional samples may be collected, as appropriate, from more easily accessible areas, if this can be accomplished without compromising the original objectives of the work.

All samples will be recorded in a field document dedicated to the investigation at York. Records will be as complete as possible, to support resolution of any issues that might arise in the future.

\subsubsection{Calibration Procedures for Field Analytical Instruments}

The technical project manager, in conjunction with team members, will ensure that instruments used for field measurements are properly calibrated, reliable, and in good working order. Standards will be protected from extreme weather conditions and will be discarded on the expiration date, so that outdated standards cannot be used inadvertently.

Calibration information for instruments used to measure the temperature, $\mathrm{pH}$, and electrical conductivity of water samples in the field will be documented in a dedicated record for each instrument. The record will include the instrument's name and model or serial number, the 
date of calibration and calibration method, and the signature of the person performing the calibration. The record will also contain dated, signed entries for all actual field measurements.

\subsubsection{Field Blanks, Field Rinsates, Field Replicates, and Trip Blanks}

The QC samples collected as part of the field sampling activity will include field blanks, field rinsates, field replicates, and trip blanks. Field blanks and field rinsates are samples of waters used for and after decontamination of field equipment, respectively. Field replicates provide a measure of consistency in both sampling and analytical methodologies. Trip blanks will be included in each shipment of samples for VOCs analyses to demonstrate that crosscontamination of samples has not occurred during shipment. The nature and frequency of these types of samples are as follows:

\section{- $\quad$ Field Blanks}

A field blank is a sample of the water used in the field for decontamination. This water will be obtained from an uncontaminated source in the field or transported to the field expressly for decontamination and other sampling activities. Blanks of other materials that might affect sample integrity will also be collected as necessary. Analysis of field blanks for VOCs will verify that contamination has not been introduced into the samples from outside sources. One field blank will be prepared during each sampling event when water is used.

\section{- Rinsates}

Some equipment (e.g., sampling bailers) is used repeatedly in sampling activities. This equipment must be decontaminated after each use to avoid cross-contamination of samples. A rinsate sample consists of water rinsed over a piece of sampling equipment after it has been cleaned and decontaminated. Rinsate samples will be collected with a frequency of 1 sample per 20 pieces of equipment cleaned, with a minimum of 1 sample per cleaning session. All rinsate samples will be analyzed for VOCs. 


\section{- Trip Blanks}

Trip blanks (soil or water) may be prepared at the AGEM Laboratory or in another suitable uncontaminated area and transported to the field site. Trip blanks may also be prepared with appropriate care at the field site. The blank sample will be shipped to the laboratory along with the field samples for VOCs analyses. A trip blank will be included in each shipping container of samples. Trip blanks will be analyzed only for VOCs. Any indication of contamination will be reported to the field team immediately, so that action can be taken to identify the source of contamination and rectify the problem.

\section{- Field Replicates/Split Samples}

Field replicates of soil, water, and vegetation samples are used to verify consistency in the sampling methodology and the reproducibility of the analytical results. The required frequency is 1 replicate for every 10 samples collected, but replicates will be collected more frequently if the particular situation warrants. All field replicates collected will be analyzed.

\subsubsection{Laboratory Quality Assurance/Quality Control for Sampling and Analysis}

\subsubsection{Laboratory Duplicates}

In addition to sample replicates prepared in the field, the analytical laboratory will select some samples at random for duplicate analyses. This procedure allows for quantitation of the precision of the laboratory analysis.

\subsubsection{Volatile Organic Analysis}

Samples collected for VOCs analyses will be shipped to the AGEM Laboratory or to an EPA-certified CLP laboratory for immediate analysis. Analysis of the samples will be prioritized in consultation with the technical project manager, so that the results can be used to optimize decision making in the field. Water samples will be analyzed by using modifications of EPA 
Methods 5030B and 8260B (purge-and-trap method on a GC-MS system) or a modification of EPA Method 524.2 (for drinking water). Soil samples will be analyzed by using a modification of EPA Methods 5030B and 8260B (Level V). Soil screening analyses (for qualitative field evaluation use only) will be performed with a modification of EPA Method 5021 (headspace analysis on a GC-ECD system). Soil gas samples will be analyzed by an EPA-certified CLP laboratory by EPA Method TO-15.

In reviewing the analytical results, $\mathrm{QA} / \mathrm{QC}$ procedures will be verified in the following laboratory-related areas:

- Chain-of-custody records for samples

- Storage of samples and sample extracts

- Holding times before analysis

- Calibration and maintenance of analytical instruments

- Performance standards for instruments (reproducibility, internal and external standards, spike recoveries, etc.)

- Field records

Verification involves thorough evaluation of laboratory practices and procedures, audits of field records, and review of data packages (both original and reduced forms of data) by the project QA/QC coordinator. The results of this evaluation, in keeping with EPA guidelines (EPA 2008), will be presented in the QA/QC portion of the sampling and analysis report. At least $10 \%$ of all water and soil samples collected at a site in a given sampling event (or a minimum of 1 sample if fewer than 10 are collected) will be shipped to an EPA-certified CLP laboratory for a second analysis to verify the results obtained by the AGEM Laboratory. Samples may be sent directly to the CLP laboratory from the field, or they may be selected for verification analysis on the basis of the AGEM Laboratory's results. When possible, the samples selected in the AGEM Laboratory will have a wide range of carbon tetrachloride values (from below the detection limit to high concentrations) to allow comparison of the analytical methods over the range of concentrations found. Water samples will be analyzed by the reference laboratory according to 
the CLP procedure SOW SOM01.2-trace (EPA 2011), with a quantitation limit of $5.0 \mu \mathrm{g} / \mathrm{L}$. Soil samples will be analyzed by using EPA Method 8260B, as referenced in the EPA's SW-846 (EPA 1998), with a quantitation limit of $10 \mu \mathrm{g} / \mathrm{kg}$. Complete CLP documentation will be provided for each sample subjected to verification analysis by the reference laboratory.

\subsubsection{Other Analyses}

Selected samples may be subjected to other analyses (unrelated to site contamination) to aid in development of the site hydrogeologic model. Groundwater samples may be selected for inorganic or tritium analysis to aid in characterization of groundwater geochemistry. Soil samples may be selected for analysis of physical parameters such as particle size, bulk density, or percent moisture. These analyses will be conducted by certified laboratories with accepted procedures. The analytical methodologies used and the results of a review of QC procedures for these analyses will be presented in the sampling and analysis report as appropriate or requested.

\subsubsection{Quality Assurance Records}

Records that document quality must be assembled and maintained. Records must be legible, identifiable, and retrievable and must be protected against damage, deterioration, or loss. Such QA records pertain to all activities related to sampling and analysis. The QA records include but are not limited to soil boring logs, well completion logs, other field records, sample labels, and chain-of-custody records. These records will be retained for a minimum of ten years after the program ends.

\subsubsection{Field Notes Related to Sample Collection}

All field notes relating to the collection of samples will be placed in the permanent project records. Notes will provide information on the sampling conditions and sample handling and collection methods. The sample identification number, the date and time of sampling, the place of collection (with a simple hand-drawn location map), the weather conditions at the time of sampling, and any measurements made by field monitoring equipment are the minimal data recorded. Each entry will be signed by the sampler. 


\subsubsection{Sample Labels}

A uniquely numbered sample label will be affixed to each sample container to identify the sample; the date, time, and location of sampling; and the analysis to be performed.

\subsubsection{Chain-of-Custody Records for Samples}

A uniquely numbered chain-of-custody record must be maintained to track the possession of each sample throughout its history, from the time of collection to the time of delivery to the analytical laboratory. The chain-of-custody record is discussed in the Master Work Plan (Argonne 2002). One copy of the chain-of-custody record will accompany each sample shipment. A second copy will be retained by the technical project manager until completion of the investigation, when it will be placed in the permanent project record.

\subsubsection{Analytical Data Reduction, Validation, and Reporting}

\subsubsection{Analytical Data Reduction}

All sampling logbooks and related records (for both sample collection and sample analysis) completed during individual tasks will be submitted to the QA/QC coordinator for storage with the project files. The analytical results, with all pertinent information about sample locations and sampling conditions, will be entered into a computer file for integration with results from other activities and for presentation in the final report.

\subsubsection{Analytical Data Validation}

If minimum QC requirements are not met by the analytical laboratory, all data from the associated batch of samples must be thoroughly scrutinized. If no analytical problems are found, the data and out-of-specification parameter(s) will be discussed in the QA/QC section of the sitespecific report. If problems with the analytical data are found, the samples associated with the batch will be reanalyzed, and the data from the reanalysis will be reported. If holding times defined in the procedure for the reanalysis are exceeded, both sets of data will be reported. In the 
final report, all sample data will be presented, along with detection limits and concentrations found.

\subsubsection{Analytical Data Reporting}

For all analyses, the laboratory data package will show, at a minimum, traceability to the sample analyzed. The data package will contain the following information:

- Project identification

- Field sample number

- Laboratory sample number

- Sample matrix description

- Date of sample collection

- Date of sample receipt at the laboratory

- Analytical method description

- Individual parameter results

- Date of analysis (extraction, first runs, and subsequent runs)

- Quantitation limits achieved

- Dilution of concentration factors

- Corresponding QC data (to include method blanks, blanks/spikes, and continuing calibrations) 
- Raw chromatogram data

- Chain-of-custody forms

- Case narrative (where appropriate)

\subsection{Field Investigation Schedule}

The proposed targeted investigation will be conducted in one or more field sessions, as required to accomplish the program objectives. The investigation will be implemented in a phased approach and will begin in the spring or summer of 2015, pending NDEQ availability and access, as determined in discussions with the NDEQ. As each element of the investigation proceeds, the NDEQ will be kept informed of progress. 


\section{Community Relations Plan}

This community relations plan identifies issues of community concern regarding field work and outlines community relations activities to be conducted during the targeted investigation at York.

Community concern is likely to increase when the field work begins and Argonne's presence becomes apparent. Effective community relations will require close contact with residents and affected property owners, both within and outside the city limits. Information will be made available, as appropriate, in the local area to ensure that interested residents are adequately informed.

Argonne will develop a fact sheet that describes the investigation and will provide copies to interested residents at and near the investigation area, as well as to the York city office. The fact sheet will provide the names and contact information for the NDEQ and CCC/USDA officials and the Argonne staff involved in the investigation.

This community relations plan is divided into sections including site description, community background, community relations objectives, timing of community relations activities, and contact list of key officials.

\subsection{Site Description}

Section 2 of this report contains a complete description of the site and its history.

\subsection{Community Background}

The incorporated city of York is governed by a mayor and city council. The city also employs a city administrator, who is appointed by the mayor and approved by the city council.

The mayor and city council meet twice monthly in the city council chamber in the York Municipal Building, 100 East Fourth Street. The meetings are held on the first and third Thursdays of each month, at 7:00 p.m. The meetings are open to the public. 
In addition to public works and other city responsibilities, the mayor and council have authority to provide and maintain the municipal water supply system. The Board of Public Works is responsible for overseeing the municipal water supply system. Board members are appointed by the mayor and approved by the city council. The city also employs a director of public works, who is responsible for the day-to-day operations of all public works, including maintenance of the municipal water supply system.

Residents within the limits of the city of York receive their drinking water from the city public water supply system, which is currently supported by 19 active wells.

The city has a web site (http://cityofyork.net/) that provides information regarding all facets of the city and city government functions. The city's municipal code, which is accessible on the web site (https://www.municode.com/library/ne/york/codes/code_of_ordinances), lists all city ordinances. A review of the code shows that the city has no ordinances prohibiting the use of private wells within city limits.

\subsubsection{History of Community Involvement}

Groundwater contamination has been an ongoing issue of concern in the York area since 1990, when NDOH first discovered VOCs in some of the city's municipal water wells.

In addition to the demonstrated effects of the VOCs contamination on some York city wells and the potential impacts to additional city wells, the EPA, NDOH, and NDEQ have worked to address impacts to private wells in the area. Sampling of numerous private wells in the area not served by the York municipal water system initially resulted in the identification of contamination in several wells in 1990. As a result, EPA first began providing bottled water to impacted households in April 1991.

Since 1991, the EPA, NDOH, and NDEQ have continued their efforts to identify and sample additional private wells in the area of the contaminant plume that is not served by the York municipal water system. As a result, TCE has been detected above the MCL in several additional private wells, and carbon tetrachloride was found in another well. 
Subsequent investigations by the EPA and NDEQ have identified two distinct areas of VOCs contamination (PCE Southeast Contamination site and PCE/TCE Northeast Contamination site). The EPA placed both of these areas on the NPL in May 2014.

\subsubsection{Key Community Concerns}

At the request of the EPA and the NDEQ, in 2013 the CCC/USDA began sampling a number of private wells and two York municipal supply wells for analysis for carbon tetrachloride and its degradation products. This sampling was performed in conjunction with groundwater sampling by the EPA and the NDEQ for multiple additional contaminants, to address the wider-area contamination in groundwater identified in the more central and southern portions of York. Presently, these private and public wells are being sampled quarterly, per NDEQ request. The CCC/USDA has provided sampling results via letter to all well owners and to the NDEQ, immediately following each sampling event. Most of the well owners have welcomed the regular sampling of their wells.

Carbon tetrachloride was identified at levels slightly below or slightly above the MCL for this contaminant in the Olson and co-op private wells, at concentrations of $7.4 \mu \mathrm{g} / \mathrm{L}$ and $4.9 \mu \mathrm{g} / \mathrm{L}$, respectively, in December 2014 and $2.4 \mu \mathrm{g} / \mathrm{L}$ and $5.1 \mu \mathrm{g} / \mathrm{L}$, respectively, in March 2015. On the basis of these findings, the CCC/USDA has initiated actions to connect the former Olson residence (now owned by Kayton) to the York municipal water supply, at the request of the property owner, the EPA, and the NDEQ.

The ongoing groundwater contamination activities in the York area are well known to the affected private well owners. Once the proposed targeted investigation begins and the presence of Argonne staff and contractors becomes apparent, other residents are likely to become curious. This community relations plan is being developed in anticipation of the potential for greater community interest. Community concerns will be gauged during and after the site investigation and addressed appropriately, as needed.

\subsection{Community Relations Objectives}

The York community relations plan has the following major objectives: 
1. Explain the CCC/USDA's investigation plans and provide general information about the hazardous waste program.

2. Present the proposed targeted investigation plan and activities to city officials and to the residents directly affected by the scope of proposed investigation. Anticipated activities include direct-push boring with the CPT and drilling with a sonic drill rig.

3. Inform city officials, the current property owner of the former CCC/USDA facility, additional stakeholders whose properties will be affected by placement of investigation locations proposed in this Work Plan, and other interested residents of the investigation's findings and developments.

4. Respond to residents' inquiries about site activities and the presence of health and environmental hazards.

5. Ensure that the public has appropriate technical information and contact points for involvement in site-related decisions.

6. Provide appropriate documentation and contact information to enable interested residents to learn about the site.

\subsection{Timing of Community Relations Activities}

This section describes the activities needed to meet the community relations objectives identified in Section 5.3. Many of these activities need to take place before the field work begins. Listed below are milestones and planned activities.

\subsubsection{Activities before Field Work Begins}

The CCC/USDA and Argonne will conduct the following community relations activities, to the extent practicable, before field work begins: 
1. A point of contact will be designated for Argonne. The individual will be Argonne's liaison with city officials and interested residents.

2. Upon obtaining approval from the CCC/USDA, Argonne will make initial contact with local residents and officials of the city government to explain proposed activities and schedules.

3. Argonne will make arrangements to present the targeted investigation Work Plan and discuss it with city officials.

4. Argonne will make arrangements to conduct discussions (by telephone and in person) with interested residents and any other affected parties, as appropriate, to address their concerns and information needs.

5. Upon completion and approval of this site-specific Work Plan, Argonne will provide a copy of the document to the city for public viewing by interested parties.

\subsubsection{Activities during Field Work}

The CCC/USDA and Argonne will provide for the following community relations activities, to the extent practicable, during field work:

1. Meetings with interested residents and other parties when needed.

2. Preparation and distribution of fact sheets or letters to inform the community of the investigation's progress, significant milestones, or changes in plans.

3. Continued telephone contact with interested residents and with state and local officials.

4. Arrangements for site visits by interested parties, within allowable safety limitations. 


\subsubsection{Activities upon Completion of Field Work Activities}

The CCC/USDA and Argonne will conduct the following community relations activities, to the extent practicable, upon completion of the field work:

1. If requested, arrange for a meeting with city officials and interested residents, as appropriate, to present and discuss the investigation's findings, results, and recommendations, as well as any future activities at the site.

2. Prepare and distribute printed information outlining the investigation's results and any future activities at the site, as appropriate.

3. Provide a copy of the final report that documents results of the investigation to the city for public viewing by interested parties.

\subsection{Contact List of Key Officials}

The contact list for use during targeted investigation is below. The list includes key federal, state, local officials, and Argonne contacts.

\section{Local Officials}

City of York, Municipal Building

100 East Fourth St.

York, NE 68467

www.cityofyork.net

402-363-2600

City Clerk-Treasurer: Jean Thiele

City Administrator

Tara Vasicek

402-363-2600

tvasicek@cityofyork.net

Director of Public Works, City Engineer

Mitchell D. Doht

402-363-2600
Mayor and City Council

Chuck Harris, Mayor

Barry Redfern, City Council President Margaret Brink, Council Vice President Ron Mogul, Jr., Council Member Cy North, Council Member Diane Wolfe, Council Member Shiela Hubbard, Council Member Matt Spanjers, Council Member Jeff Pieper, Council Member 


\section{Federal Agency Officials}

\section{Steve Gilmore}

Conservation and Environmental Protection Division

Farm Service Agency

Commodity Credit Corporation

U.S. Department of Agriculture

Room 4725, Stop 0513, South Agriculture Building

1400 Independence Avenue, SW

Washington, DC 20250-0513

202-720-5104

Steve.Gilmore@usda.gov

\section{State Agency Officials}

\section{Mike Felix}

Remediation Section

Waste Management Division

Nebraska Department of Environmental Quality

Suite 400, The Atrium, 1200 N Street

P.O. Box 98922

Lincoln, NE 68509-8922

402-471-2938

402-471-2909 (fax)

mike.felix@nebraska.gov
Laurie S. Brunner

Groundwater Geologist

Remediation Section

Waste Management Division,

Nebraska Department of Environmental Quality

Suite 400, The Atrium, 1200 N Street

P.O. Box 98922

Lincoln, NE 68509-8922

402-471-3377

402-471-2909 (fax)

wade.gregson@nebraska.gov

\section{Argonne Contacts}

Lorraine M. LaFreniere, Ph.D.

Manager, Applied Geosciences and Environmental Management Section

Environmental Science Division

9700 South Cass Avenue

Argonne, IL 60439-4843

630-252-7969

lafreniere@anl.gov

Robert Sedivy

York Project Manager

Environmental Science Division

9700 South Cass Avenue

Argonne, IL 60439-4843

402-465-9021

RAsedivy@anl.gov
James Hansen

Community Relations Representative

Environmental Science Division

Argonne National Laboratory

955 L'Enfant Plaza SW, Suite 6000

Washington, DC 20024

202-488-2453

hansenj@anl.gov 


\section{Health and Safety}

The general health and safety plan for use during the work at York is in Section 3 of the Master Work Plan (Argonne 2002). That document addresses all anticipated safety issues for the activities at the York site. Specific emergency information for use at the site is in Table 6.1.

The former CCC/USDA facility, on property owned by DPKG, LLC, lies outside the City of York, in York County. This property is located at 3295-3489 North Division Avenue. Other investigation locations are in the City of York. York County has 911 emergency service. All 911 emergency calls — sheriff/police, fire, and ambulance calls, within and outside the York municipal limits - will be directed to the appropriate jurisdiction for response.

Major medical services are provided by York General Hospital at 2222 North Lincoln Avenue, approximately $1.3 \mathrm{mi}$ from the former CCC/USDA facility. Driving directions to the hospital and a map showing the route are in Figure 6.1. Additional emergency information is in Table 6.1. 
TABLE 6.1 Emergency information for the investigation at York, Nebraska. ${ }^{a}$

\begin{tabular}{|c|c|c|}
\hline Resource & Telephone Number & Name \\
\hline All Emergencies & 911 & York County Emergency Response \\
\hline York General Hospital & $402-362-6671$ & 2222 N. Lincoln Ave., York, NE 68467 \\
\hline York Medical Clinic & $402-362-6671$ & 2114 N. Lincoln Ave., York, NE 68467 \\
\hline Severe Weather Updates & FM 104.9 & Radio Station KTMX \\
\hline Non-Emergency Services & & \\
\hline $\begin{array}{l}\text { York County Office } \\
\text { (includes sheriff) }\end{array}$ & $402-362-4927$ & $\begin{array}{l}510 \text { N. Lincoln Ave., York, NE } 68467 \\
8 \text { a.m. to } 5 \text { p.m., Monday-Friday }\end{array}$ \\
\hline York City Hall & $402-363-2600$ & 100 E. 4th St., York, NE 68467 \\
\hline York Police Department & $402-363-2640$ & 315 Grant Ave., York, NE 68467 \\
\hline York Fire Department & $402-363-2610$ & 815 N. Grant Ave., York, NE 68467 \\
\hline Industrial Hygiene & $630-252-3310$ & Argonne-Industrial Hygiene \\
\hline Safety & $630-988-9706$ & EVS Divisionc Field Safety Coordinator (Monte Brandner \\
\hline \multirow[t]{4}{*}{ Management } & $630-252-4878$ & $\begin{array}{l}\text { EVS Division }{ }^{\mathrm{C}} \text { Environmental, Safety, and Health } \\
\text { Coordinator (Bill Gasper) }\end{array}$ \\
\hline & $630-252-7969$ & AGEM Program Manager (Lorraine LaFreniere) \\
\hline & $\begin{array}{l}630-252-1275 \\
630-408-7114\end{array}$ & AGEM Field Project Manager (David Surgnier) \\
\hline & $\begin{array}{l}402-465-9021 \\
402-429-5144\end{array}$ & AGEM Technical Project Manager (Bob Sedivy) \\
\hline Security & $\begin{array}{l}630-252-5737 \\
630-252-5731\end{array}$ & $\begin{array}{l}\text { Argonne-Operations Security (workdays) } \\
\text { (after hours and weekends) }\end{array}$ \\
\hline Poison Control & $800-222-1222$ & Nebraska Regional Poison Center \\
\hline Utilities Survey & $800-331-5666$ & $\begin{array}{l}\text { Diggers Hotline of Nebraska, Omaha, NE } \\
\text { http://www.ne1call.com/ }\end{array}$ \\
\hline
\end{tabular}

a Post this table in the field operations base. The former CCC/USDA facility is located at 3295-3489 N. Division Ave.

b The route from the investigation site to York General Hospital is shown in Figure 6.1.

c Environmental Science Division at Argonne. 
From the site, follow Division Avenue south to 25th Street. Turn left (east) on 25th Street and proceed to Lincoln Avenue. Turn right (south) on Lincoln Avenue and proceed to the hospital, on the left, at 2222 Lincoln Avenue.

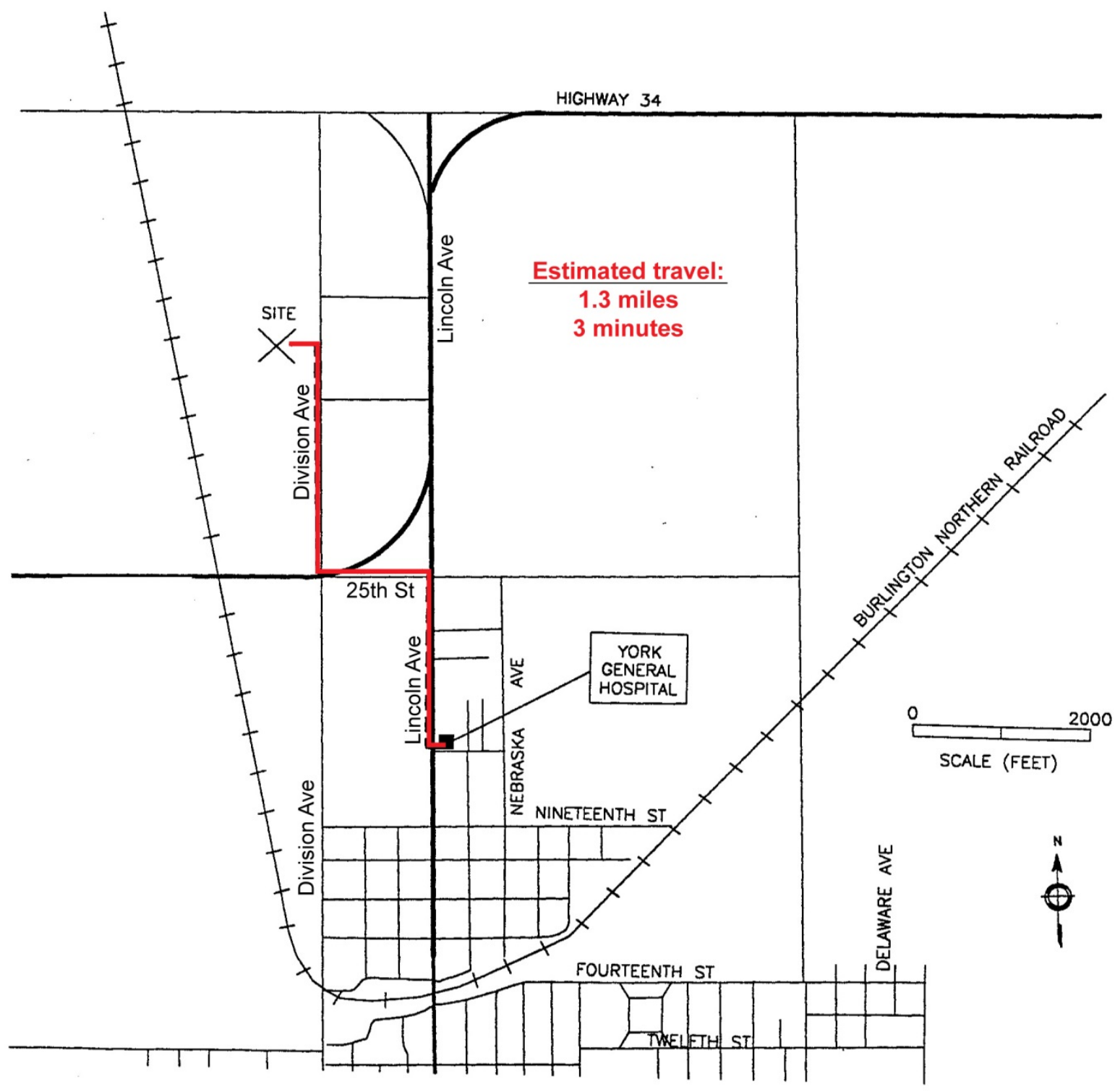

FIGURE 6.1 Route from the investigation site to York General Hospital. 


\section{References}

Alvarado, J.S., and C. Rose, 2004, "Static Headspace Analysis of Volatile Organic Compounds in Soil and Vegetation Samples for Site Characterization," Talanta 62:17-23.

Argonne, 1993, Final Work Plan: Phase I Extended Site Characterization, York, Nebraska, prepared for the Commodity Credit Corporation, U.S. Department of Agriculture, Washington, D.C., by Argonne National Laboratory, Argonne, Illinois, June.

Argonne, 1994, Final Phase I Report and Phase II Work Plan: Expedited Site Characterization, York, Nebraska, prepared for the Commodity Credit Corporation, U.S. Department of Agriculture, Washington, D.C., by Argonne National Laboratory, Argonne, Illinois, February.

Argonne, 1995a, Final Phase II Report: Expedited Site Characterization, York, Nebraska, prepared for the Commodity Credit Corporation, U.S. Department of Agriculture, Washington, D.C., by Argonne National Laboratory, Argonne, Illinois, April.

Argonne, 1995b, Final Feasibility Study for Remedial Action at York, Nebraska, prepared for the Commodity Credit Corporation, U.S. Department of Agriculture, Washington, D.C., by Argonne National Laboratory, Argonne, Illinois, November.

Argonne, 2002, Final Master Work Plan: Environmental Investigations at Former CCC/USDA Facilities in Nebraska, 2002 Revision, ANL/ER/TR-02/003, prepared for the Commodity Credit Corporation, U.S. Department of Agriculture, Washington, D.C., by Argonne National Laboratory, Argonne, Illinois, December.

Clark, B.R., M.K. Landon, L.J. Kauffman, and G.Z. Hornberger, 2008, Simulations of GroundWater Flow, Transport, Age, and Particle Tracking near York, Nebraska, for a Study of Transport of Anthropogenic and Natural Contaminants (TANC) to Public-Supply Wells, Scientific Investigations Report 2007-5068, U.S. Geological Survey, Reston, Virginia (http://pubs.usgs.gov/sir/2007/5068/).

EPA, 1996, Expanded Site Inspection for the York Public Water Supply Site (Volumes I and II), October. 
EPA, 1998, Test Methods for Evaluating Solid Waste: Physical/Chemical Methods, EPA SW846, 3rd edition, Draft Update IVA, U.S. Environmental Protection Agency, Washington, D.C., January.

EPA, 2008, National Functional Guidelines for Superfund Organic Methods Data Review, OSWER 9240.1-48, USEPA-540-R-08-01, Contract Laboratory Program, Office of Superfund Remediation and Technology Innovation, U.S. Environmental Protection Agency, Washington, D.C., June (http://www.epa.gov/superfund/programs/clp/download/somnfg.pdf).

EPA, 2011, SOM01.2 Volatile Target Compound List and Corresponding CRQLs, Contract Laboratory Program, Superfund Analytical Services, August 9 (http://www.epa.gov/superfund/ programs/clp/som-vtarget.htm), accessed October 272014.

EPA, 2013a, HRS Documentation Record, PCE/TCE Northeast Contamination, U.S. Environmental Protection Agency, Region 7, Lenexa, Kansas, December (http://www.epa.gov/superfund/sites/docrec/pdoc1887.pdf).

EPA, 2013c, HRS Documentation Record, PCE Southeast Contamination, U.S. Environmental Protection Agency, Region 7, Lenexa, Kansas, December (http://www.epa.gov/superfund/ sites/docrec/pdoc1886.pdf).

EPA, 2014a, National Priorities List: PCE Southeast Contamination, York, Nebraska, narrative summary, U.S. Environmental Protection Agency, Washington, D.C., May (http://www.epa.gov/superfund/sites/narr/nar1886.pdf).

EPA, 2014b, National Priorities List: PCE/TCE Northeast Contamination, York, Nebraska, narrative summary, U.S. Environmental Protection Agency, Washington, D.C., May (http://www.epa.gov/superfund/sites/narr/nar1887.pdf).

EPA, 2014c, Water System Details for City of York, information from U.S. Environmental Protection Agency Safe Drinking Water Information System via Nebraska Department of Health and Human Services, Drinking Water Branch (http://sdwis-dhhs.ne.gov:8000/DWW/), accessed October 23. 
EPA, 2014d, Exposure Assessment Models: WhAEM2000, U.S. Environmental Protection Agency, Washington, D.C. (http://www2.epa.gov/exposure-assessment-models/whaem2000), accessed October 22 .

Keech, C.F., V.H. Dreezen, P.A. Emery, 1967, Availability of Ground Water in York County, Nebraska, U.S. Geological Survey Water-Supply Paper 1839-F, U.S. Government Printing Office, Washington, D.C. (http://pubs.usgs.gov/wsp/1839f/report.pdf).

Landon, M.K., and M.J. Turco, 2007, "Hydrogeologic Setting and Ground-Water Flow Simulations of the Eastern High Plains Regional Study Area, Nebraska," Section 8 of Hydrogeologic Settings and Ground-Water Flow Simulations for Regional Studies of the Transport of Anthropogenic and Natural Contaminants to Public-Supply Sells - Studies Begun in 2001, edited by S.S. Paschke, Professional Paper 1737-A, U.S. Geological Survey, Reston, Virginia (http://pubs.usgs.gov/pp/2007/1737a/Section8.pdf).

Landon, M.K., B.R. Clark, P.B. McMahon, V.L. McGuire, and M.J. Turco, 2008, Hydrogeology, Chemical Characteristics, and Transport Processes in the Zone of Contribution of a PublicSupply Well in York, Nebraska, Scientific Investigations Report 2008-5050, U.S. Geological Survey, Reston, Virginia (http://pubs.usgs.gov/sir/2008/5050/).

NDEC, 1990, Preliminary Assessment, York Ground Water Contamination Site, York, Nebraska, Nebraska Department of Environmental Control, Lincoln, Nebraska, Report NED986375483, August.

NDEC, 1991, Site Investigation: York Ground Water Contamination Site, York, Nebraska, Report prepared by Nebraska Department of Environmental Control, Lincoln, Nebraska, for U.S. Environmental Protection Agency, Region VII, Lenexa, Kansas, September 10.

NDEQ, 2010, Final Site Inspection, Revision 01, York Northeast Groundwater Site, York, Nebraska, Nebraska Department of Environmental Quality, Lincoln, Nebraska, May 17.

NDEQ, 2011, Final Expanded Site Inspection Report, Revision 01, Nebraska Department of Environmental Quality, Lincoln, Nebraska, January 19. 
NDEQ, 2014, letter from K. Boone (Remediation Section, Waste Management Division, Nebraska Department of Environmental Quality, Lincoln, Nebraska) to S. Gilmore (Commodity Credit Corporation, U.S. Department of Agriculture, Washington, D.C.), regarding the former CCC/USDA grain bin facility at York, January 17.

PES, 1991, In-Situ Soil Gas Survey of York Contamination Site (NED986369981), York, Nebraska, Plains Environmental Services, Salina, Kansas, June.

SETI, 2011, Removal Site Evaluation/Site Inspection Report for Southeast York Groundwater Site, York, York County, Nebraska, Seagull Environmental Technologies, Inc., Wheat Ridge, Colorado, February 16.

Tetra Tech, 2012a, Integrated Site Assessment York Tetrachloroethene (PCE) Site, York, Nebraska, prepared for the U.S. Environmental Protection Agency, Region 7, Lenexa, Kansas, February 14.

Tetra Tech, 2012b, Removal Site Evaluation and Site Inspection Southeast York Groundwater Site York County, Nebraska, prepared for the U.S. Environmental Protection Agency, Region 7, Lenexa, Kansas, February 16.

Tetra Tech, 2012c, Trip Report and Data Summary, Removal Action Support, York Tetrachloroethene (PCE) Site, York, Nebraska, prepared for the U.S. Environmental Protection Agency, Region 7, Lenexa, Kansas, December 4.

USDA, 1956, aerial photograph of York, Nebraska, Aerial Photography Field Office, Farm Service Agency, U.S. Department of Agriculture, Salt Lake City, Utah, July 25.

USDA, 1962, aerial photograph of York, Nebraska, Aerial Photography Field Office, Farm Service Agency, U.S. Department of Agriculture, Salt Lake City, Utah, July 30.

USDA, 1968, aerial photograph of York, Nebraska, Aerial Photography Field Office, Farm Service Agency, U.S. Department of Agriculture, Salt Lake City, Utah, July 14.

USDA, 1974, aerial photograph of York, Nebraska, Aerial Photography Field Office, Farm Service Agency, U.S. Department of Agriculture, Salt Lake City, Utah, November 4. 
USDA, 1977, aerial photograph of York, Nebraska, Aerial Photography Field Office, Farm Service Agency, U.S. Department of Agriculture, Salt Lake City, Utah, September 9.

USDA, 1981, aerial photograph of York, Nebraska, Aerial Photography Field Office, Farm Service Agency, U.S. Department of Agriculture, Salt Lake City, Utah, October 26.

USDA, 1988, aerial photograph of York, Nebraska, Aerial Photography Field Office, Farm Service Agency, U.S. Department of Agriculture, Salt Lake City, Utah, August 16.

USDA, 1993, aerial photograph of York, Nebraska, Aerial Photography Field Office, Farm Service Agency, U.S. Department of Agriculture, Salt Lake City, Utah, date unknown.

USDA, 1999, aerial photograph of York, Nebraska, Aerial Photography Field Office, Farm Service Agency, U.S. Department of Agriculture, Salt Lake City, Utah, date unknown.

USDA, 2012, aerial photograph of York, Nebraska, Aerial Photography Field Office, Farm Service Agency, U.S. Department of Agriculture, Salt Lake City, Utah, July 31.

York, 2014, Water, Public Works Office, York, Nebraska (http://www.cityofyork.net/ department/division.php?structureid=19), accessed October 23. 


\section{Appendix A:}

Nebraska Wellhead Protection Area Maps for the York Public Water Supply System 


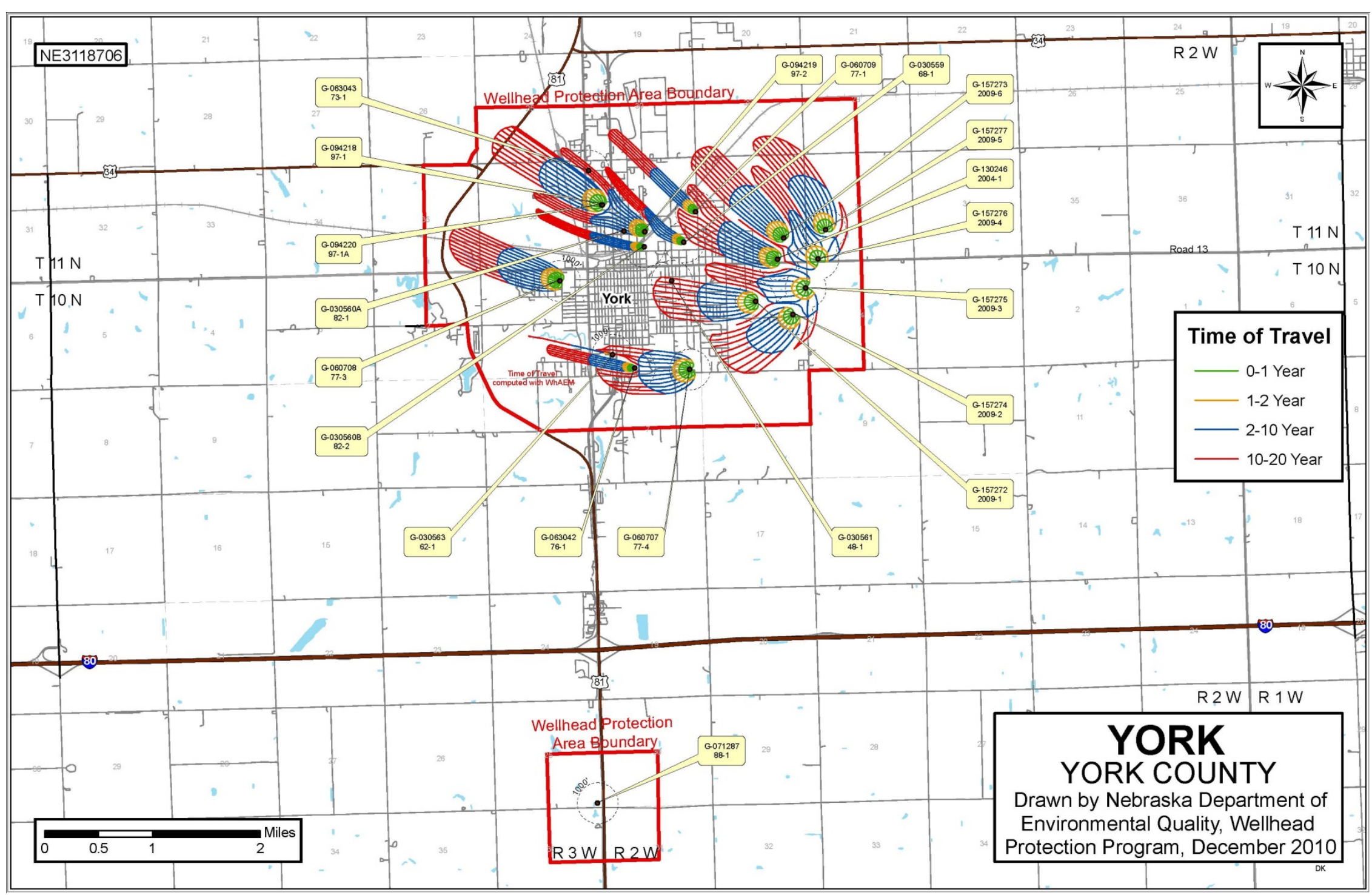

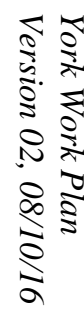




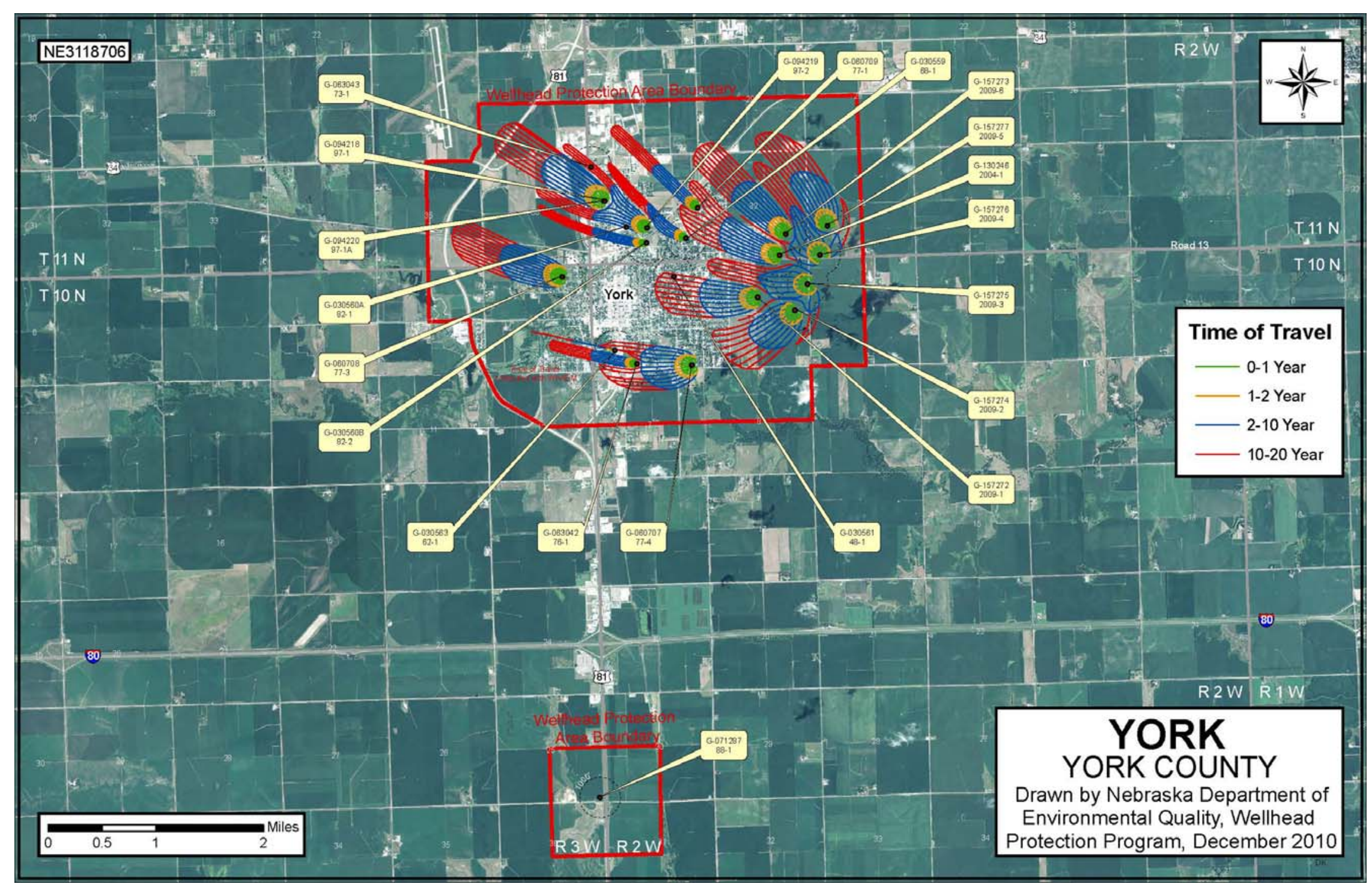

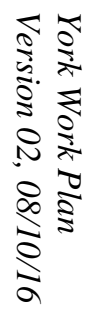


Supplement 1:

\section{Historical Property Ownership Records}


Copies of Leases

Former CCC/USDA Facility 
LEASE WITF OPITOH TO PIRC:"ASE Maron F. Rauth nnd Anna T. Rauth Filed Por Record May 2, 1950, at 4:05 P.N.

Frad Voss Jr., County Clerk.

Commodity Credit Corporation.

Fee, $82.75 . \mathrm{V}$ No. $500 \mathrm{n}$

LEASE WTTH OPTION TO PURCHLSE

THIS LEASE, made enci elltered into this 1st day of Apr11, 1950, by and between

Aaron $\Xi$. Ral th of York, Nebrrsisa Rt/l1, Lessor, and Commod1ty Cred1t Corporet1on, Legsee.

WIT:ESSETH THAT:

1. The Lessor leases to the Lissee, nnd the ressee hereby leases from the Lessor, uoon the terms nnd conditions bereinafter stated, the rollowing described real estate (hereinefter called "property") situated in the county of York ond stete of liebranka, consisting of square feet of space in islock , Lot subaivision

Town or ; or the of the s.e of the IIE of $1 / 4$ of section 25

Townsk1p 11 Range 3, to permit the placing thereon or C.C.C. owned grenarles and racil1ties. Th1s space is located os mdicated hereln:

3.16 asres located in the northerst. (JV) corner of the South Jialf (St)

of the Nortiseast Quarter (NE?), Saction Twanty-Five (25), Township

Eloven (11), Range Three (3), York0ounty, Nobraska.

2. The term of the lease shell be fcr a perlod of flve jears, cormencling the "Ist day of Apr 11, 1950, and ending the 1st day of Cctober, 195l, with the right of the Lessee to termirate sald lease, and liabll1ty for any further rent, on the rlrst day of any month of anj year, by giving thirty days' previous notice in writing to the Lessor.

3. As rent for,sald property, the Lessee shall pay the Lessor 330.00 per acre inolzass. (\$94:80) per yenr; such rent to be payable october 1 of each yonr.

4. The Lessor warrants that he is the owner of the property, has the right to give the Lessee possesition under this leese, and vill, so long as this lcase remeins in erfect. warrent and delend the Lessee's possession agfinst. any and ell persons rhomsoever. *

5. The I.essee shell heve the ripint to cor truct or ezect storage structures or recilities cn sald property "nd, at the exilretion of sfld lease or any regewel or extinsion theroof or at any time this leese is in effect, ray remove said storage strucsures or freilleles or any part tharcor, whether or not such structures or facllities have becore legelly e fixture. It 1s, therefore, heruby agreed that the lesseo shall have the right of Ingress end egress at any time to the space herein leacod.

6. The Lessele shril not asign this lease nor sublet said property or eny part theroor without the written congent of the Lessor.

7. The Lessor hereby reserves unto 1 tself, and/or 1 ts lessees, the right to operate, meintein enörener such pipe 11nes, electric trensmisston Iines, telephone 11nes, tolegraph lines, signal lires end otker faclilties of like character as may exist upon, under or over the leesed premises as of tre gate of tisis le.se, it being agreed that this leese is subject and subordinente to eny ond all-rights granted by the Lessor for any such existing, lines and sacilities.

It is rurterer agreed thet upon the expiration of this loase, or in case tine iesseo shell in eng acnier fell to comply with the terms and conditions hereor, the wessee shall, rortiwith, cease to use or remain upon srid premises and shall remove all the Improvements pleced thereon by the iessee and restore arld premises to substantially their rormer state.

If the Lessee fails to surronder to the Lessor the leaged premises, upon eny terminetion or explration of this lease, gll the libblities and obligations of the Lessee herounder shell continue in effect until the leased premlses are surrendered, and no termination or expiration hereor shell releese the Lessee rrori fny lievility or obl1-

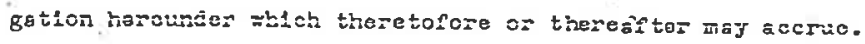


It $1 \mathrm{~s} f$ irtiser agreed that this losse shall be binding upon the Lessee a nd assigns of the Lejseo, "and shall Innure to the benerit of the Lessor, 1 ts successors and essigns.

No menber of or Delegate to Congress or Regldent Commissioner shall he admitted to rny shere or part of this agreerient or to any benerit to arloe therefrom. Nothing, however, herein contalned shall be construed to extend to any incorroreted company, 11. the egroement be for the generel benefit of guch corporation or compeny.

8. The Lessor grants and gives the Lessea the option, at any time while this leasio is in effect, to purchase said property from the Lesaor, his helrs, executors, adminlstrators, and assigns, for the sum of the appraised value lollarg (\$ $)$

In the event the Legsee shall exercise th1s option to purchase sa1d property, the Lessor agrees to execute a good and surficient warrenty deed convoying reo simple title to said property free end clear of all taxes, Jiens, or encumbrences except for the followling end no others:

IN TEST THOFY :2HEREOF, the parties heve executed this instrument in duplicate this day nnd jeir first above written.

R1chard H. Stephens :H tness

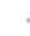

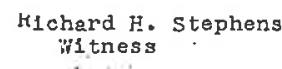

on tiiss 21 day of Apr11, 1950, beforo me a Notary Publ1c in and for sald county sersonelly ceme the ibove-named Naron F. Rauth and Ama T. Rauth, husband a nd w1fe who is personally known to me to be the 1centicnl person whose neme is arrixed to the above 1nstrument as Lessor end he acknowledged sa1d instrument to be his voluntary act and doed. iiltness my hand end notorial seal, the dete $2 a s t$ aroresald.

Yy Comolgsion explres on the 12 dar or May, 1955. 17. A. Rersizueg General Notary State of Hebraska * H.A. Refaheuge Notery Publlc Comisision Explres

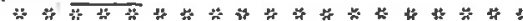
(SEAL)

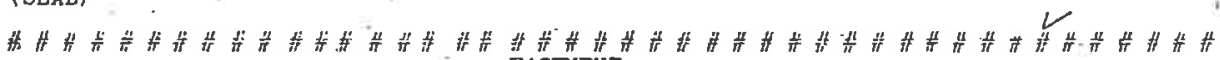
York cold storage Co. EASEN:ENT Filod for Record May 3, 1950, at 6:30 A.H. Fred Voss Jr, County Clerk. Consumers PubIlc Power D1strict. Feo, \$2.50. No. 5014 Fore N3-Rev. $4-48$ EASEMENT FOR ELECTRIC LINES KNOW AID MEN BY THESE PRESENTS:

That York cosd Storage Co. (If grantor 13 not married add words "an anmarrled person") of York county, Nokreska, in consideration of $\$ 1.00$, recelpt of whlch is hereby ack-

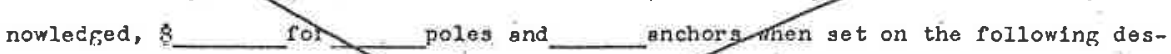
cribed property, do hereby frapt end convey upto the Consurers Public Power District

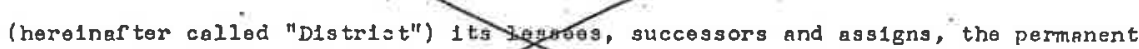
right, privilege and easement of oright-orapy to construct, operpte, maintain and remove ell necossary poles, wires, guys and other hacessary equipment in conisection therew 1 th, on and acjoss the rollowlng described property blutu ted in York county, Nebraka, more particularly described as rollows:

Lots 1, 2 and 3, Block 42, Nen York Addition, C1ty of York Nebraska. The pole line herein contemplated shell be located on the property opproxkpately rollows: 


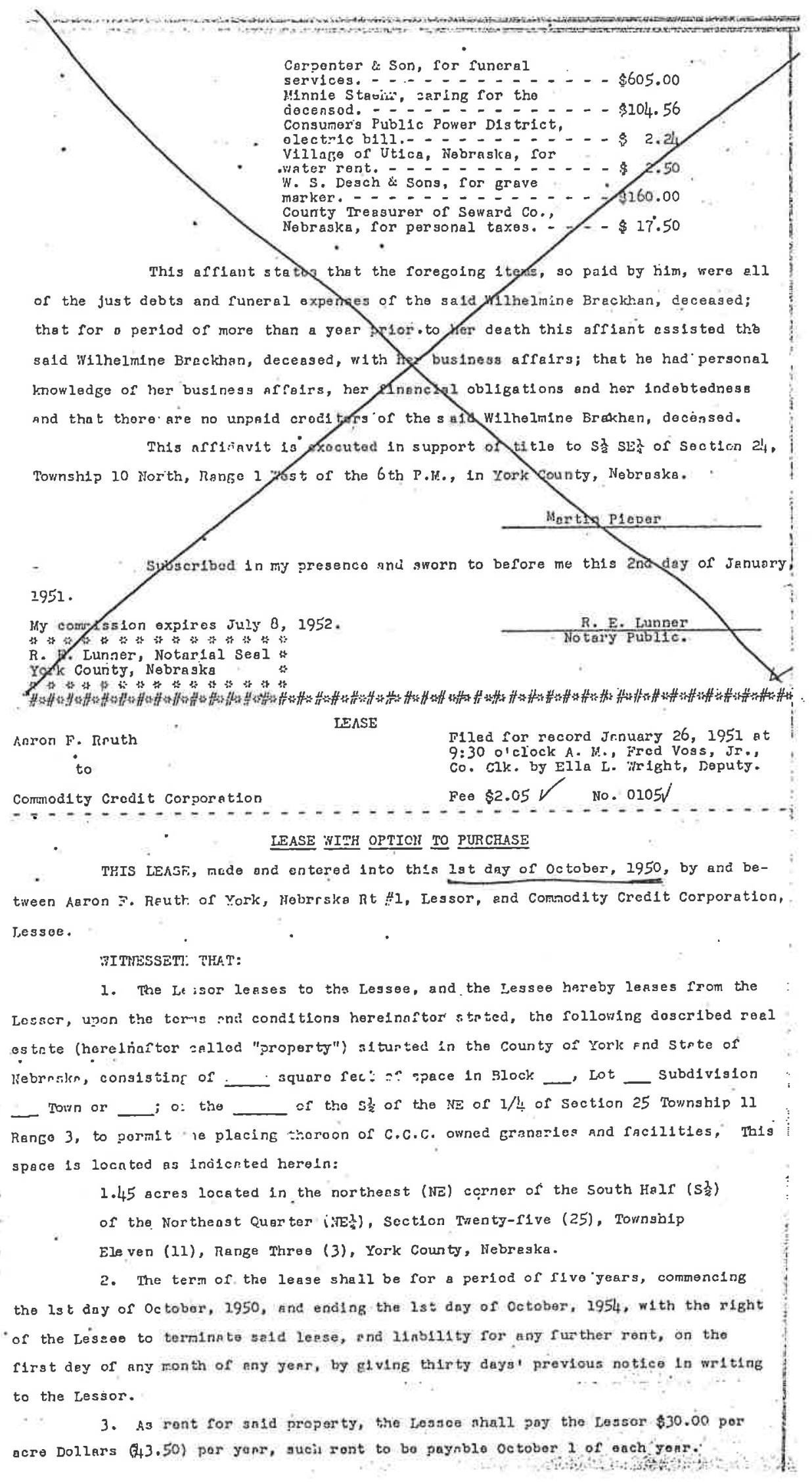




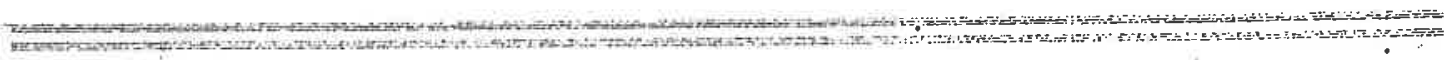

4. The Lessor warrants that lie 13 the owner of the proporty, has the right

: to give the Lessee possession under this loase, and will, so long as this lease remalns in erfect, warrent and defend the Lesseels possession ageinst any rad all persons whomsoever.

5. The Jessee shal. I have the right to conatruct or erect storage structures or faclilties on snid property and, at the oxplration or sald lopse or any renowal or extension thereof or at any time thes lease is in offect, nir: remove sald storere atructurce or faclilties or any pert thercor, whether or not such structures or facllties have become legally a riyture. It is. therofore, hereby agreed that the Lessee shall

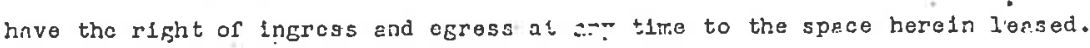

6. The Lesser shall not essign this lense nor sublet sald property or any part thoncof without the written consent of the T.essor.

7. Tho Lessor herobj reserveg unto itself, ond/or itsilessees, tlue right to operate, maintain and renuw such pipe linos, eluctric transmission lines, tolophone lines, telegraph lines, signal lines and other facilities of like character as may exist upon, under or over the leased premises ns of tho dite of this lease, it being agreod thrt this lease is subjoct and subordinate to ony and nil rights grented by tho lessor? for eny such, existing lines and racilities.

It is furthor agreed that upon the expiration of this lease, er in case the Lessee shell. In any manier fell to comply with the terms and conditions hereor, the. Jessoe shnll, festhwith, conse to use or rempin upon sald premiscs nnd ahril remove sll the improvoments pliced thoreon by the I.csseo pnd restorc snid presises to substnntally ithe1r romer state.

If the Losseo falls to surreni:: in the Lessor the lesised premlses, upor ans torminntion or expiration of this lease, r.l the liabilities and obligations of the Lessee herounder shril continue in effect until the loased prenlscs ere surrenderod, end no terminntion or explrntion hereof shall release the Lessee rrom any. 11 ab1I1ty or obligetion horeunder which ther:tolore or thereasitor may accrue.

It is :urther agreed thet this lease shali be sinding upon thu lusseo and essigns of the Lessee, nnd shall inure to the benerit of the Lessor, 1 ts successors and assigns.

No member of or Delegate to Congress or Resident Comissicnar shaj.I ba admittod to ony share or pret of this agrecment or to nny benofit to arlse therefrom. Nothing, however, hereln contained shrll be collstrued to extend to eny incorporated compeny, if the prreemont be for the genernl beneflt of such cormoration or company.

a. The Iessor ernnts and fives the Iossoe the option, wi any time while this lcasc is in effoct, to purchrac snid sroperty from the Lessor, his helrs, executors,

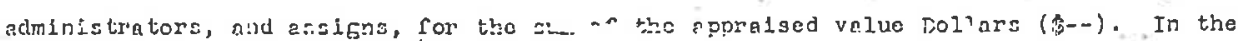
event the Lossec shall exercise this option to purchane sele property, the Lessor ogroes to oxecute a good ond surficient warrenty deco conveying ree simple tifle to seld property rree and clear of ell taxes, llens, or encurbrences excopt for the followlng and ino others:

IN TESTI MONY WHEREOF, the partios have executed this instrument in duplicate this day and year rirst nbove written.

Dor1s P. Plokrel iiltress
Aaron F. Rauth LESSOR By

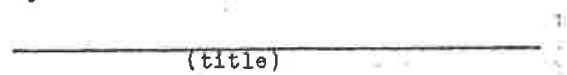




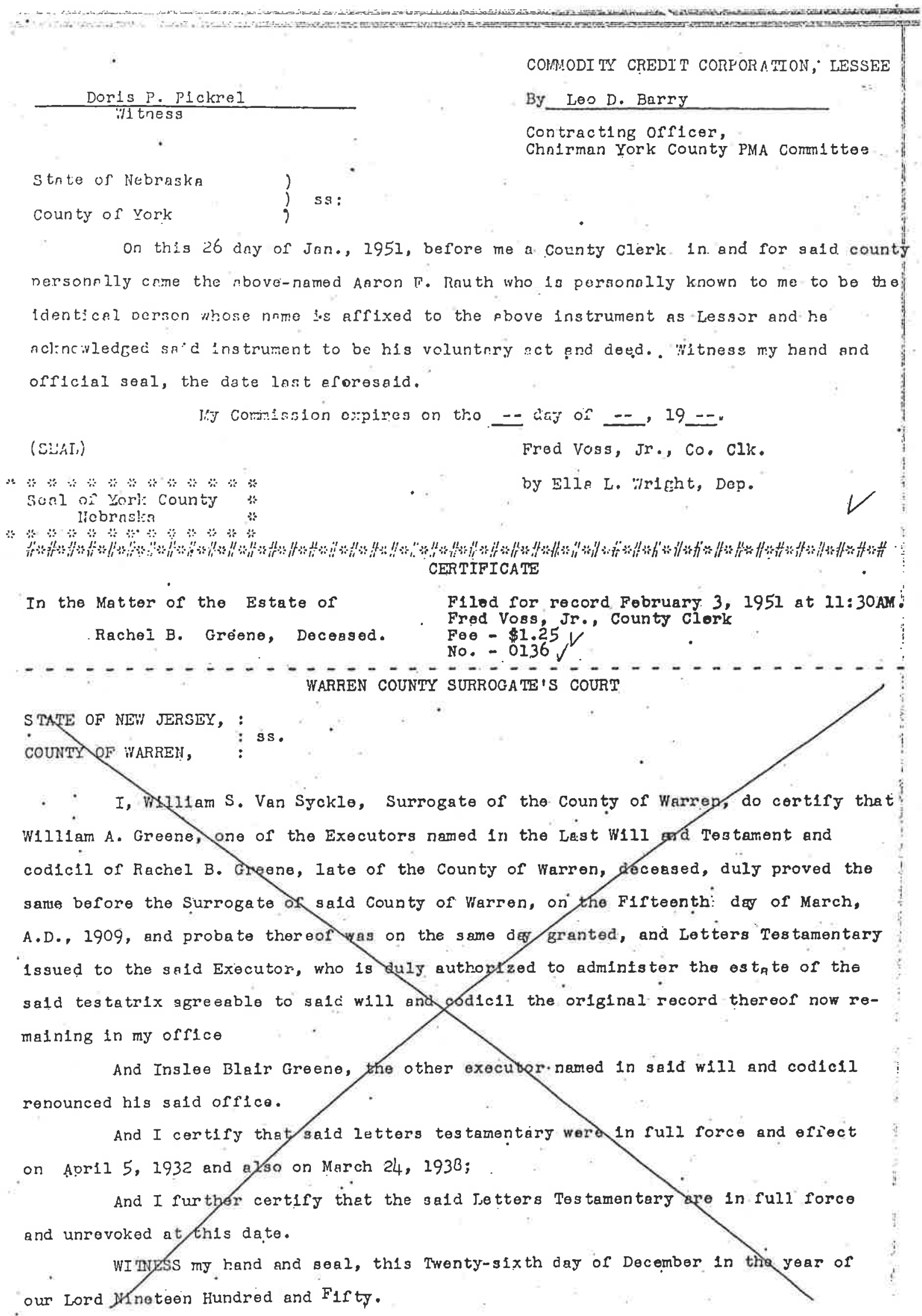




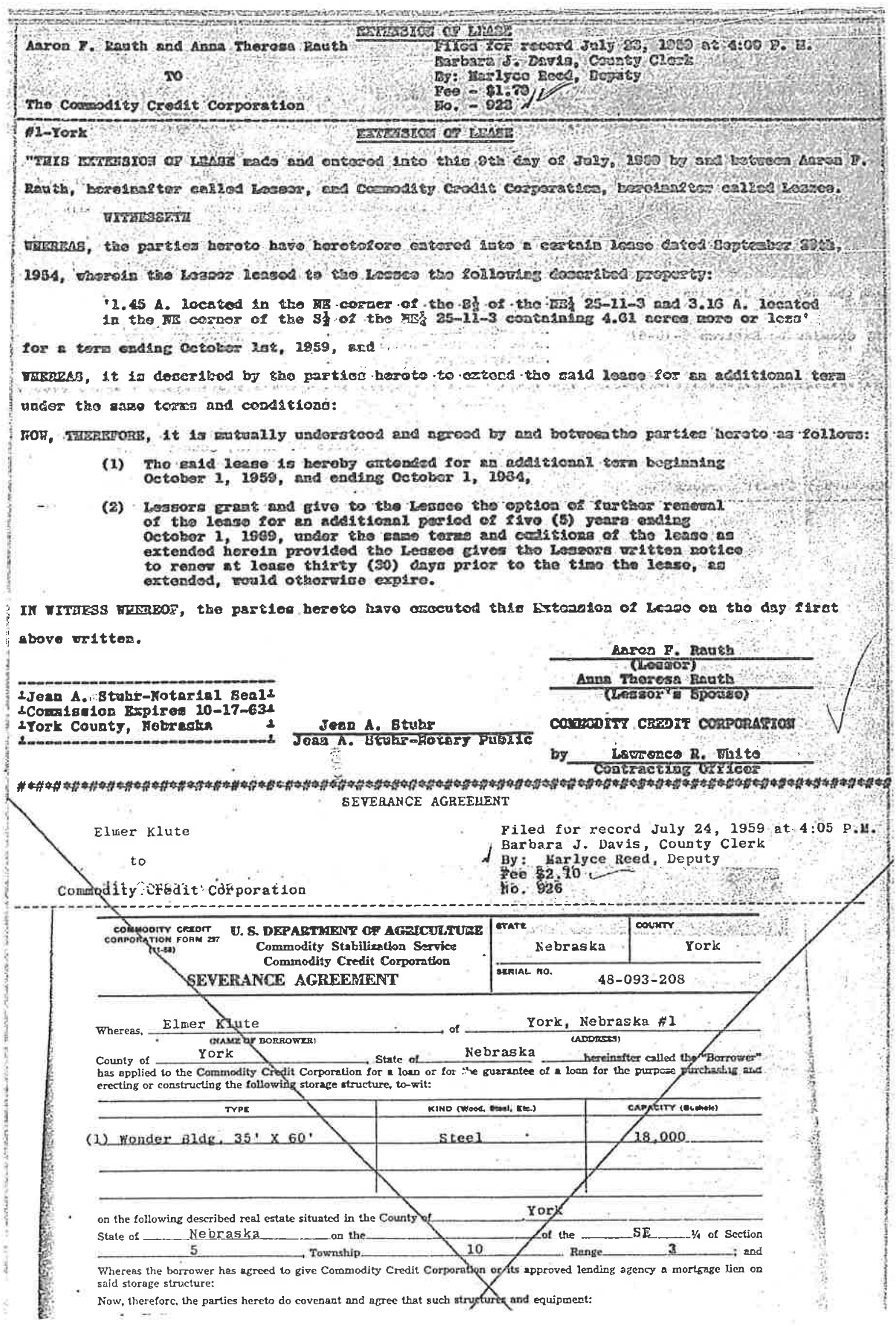


ronu cec onaik-10

prestint

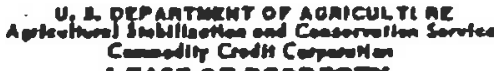
Lens: of Properth

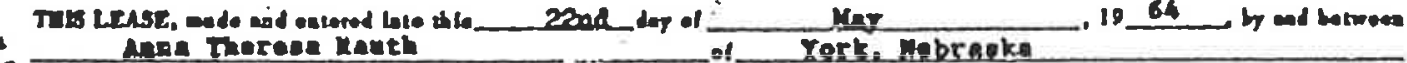

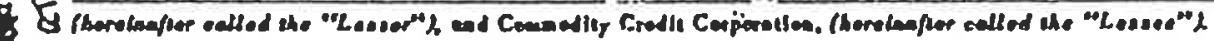

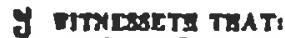

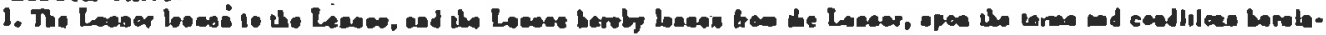

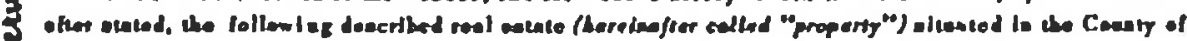
Yort

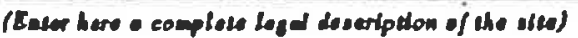

and Stale of Yohrentu

1.45 a lecated in the we comer of the $s$ t of the Hit 25-11-3

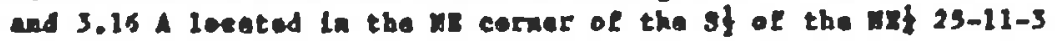
contalulag 4.61 ecrove ore of $100^{\circ}$. or Parther denerlbed as:

'Eron the us corner of g\} wh 25-11-3 - tret the center of the reed. wet 3.60 ehelve. thes sonth 12.32 chalne, then onet 3.50 chale, then morth 12.92 ehilos." ( 1 chaln - 66 et.)

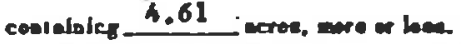

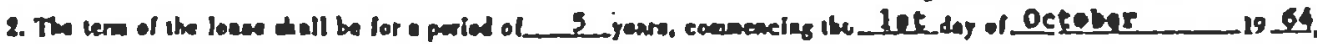

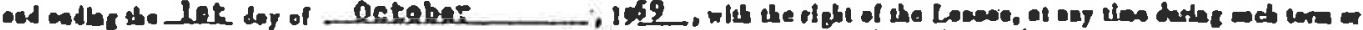

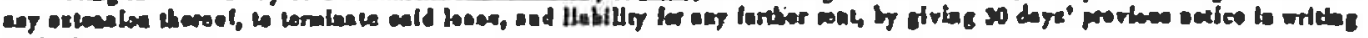
L in leares.

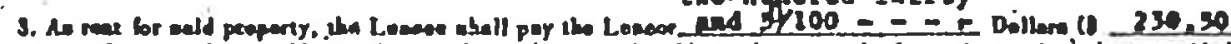

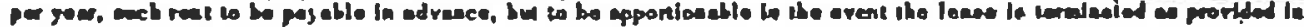
parerepd 2 berent:

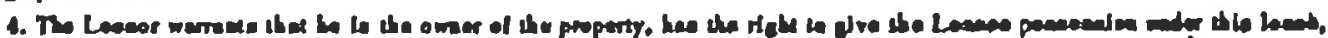

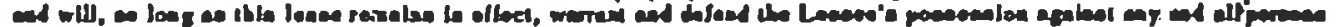
Howomer.

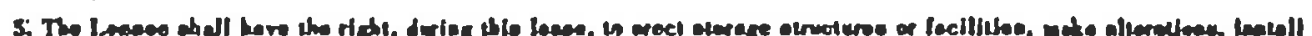

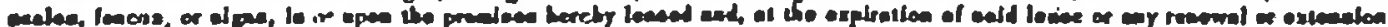

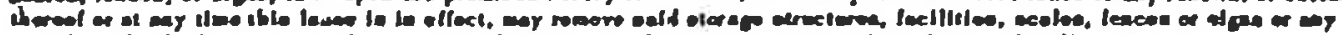

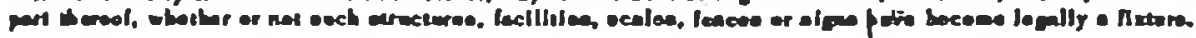

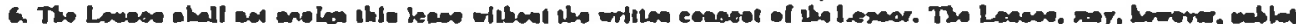

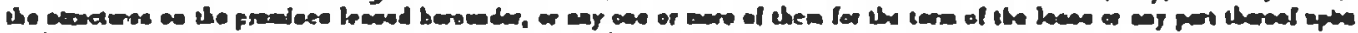

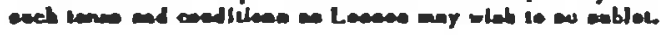

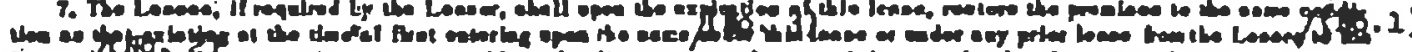

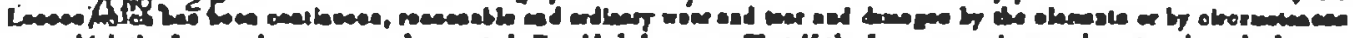

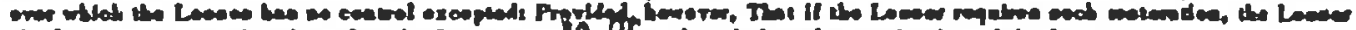

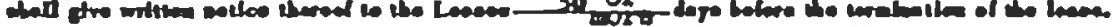

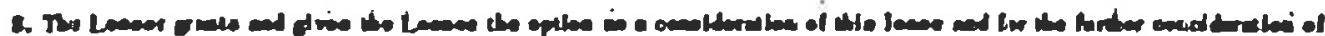

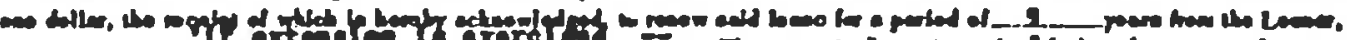

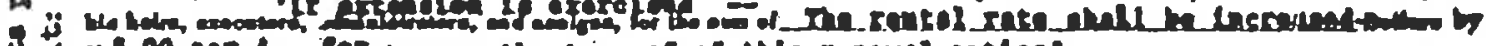

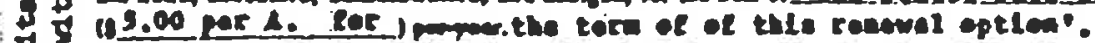

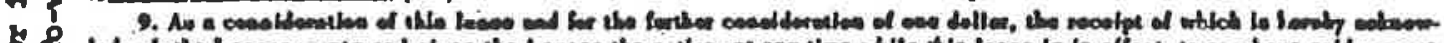

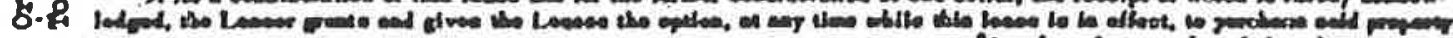

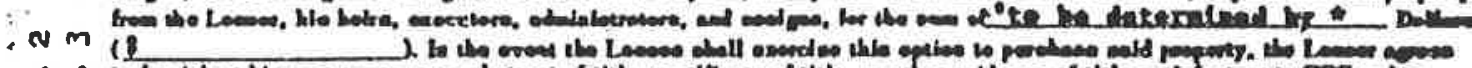

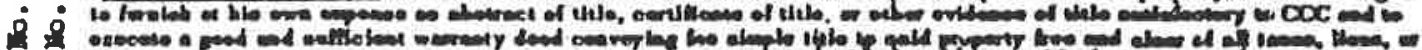

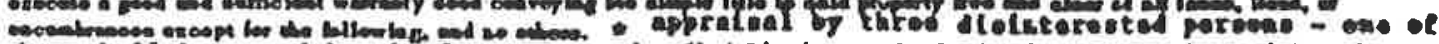

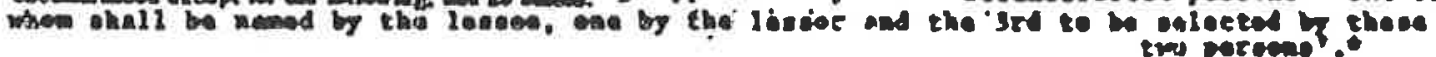




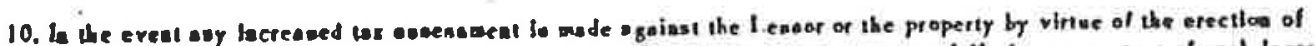

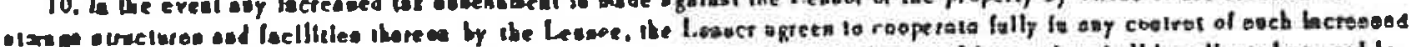

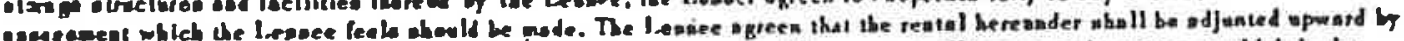

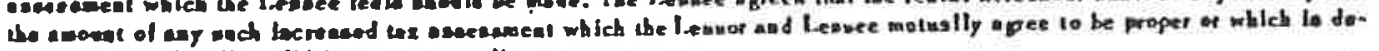

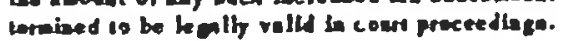

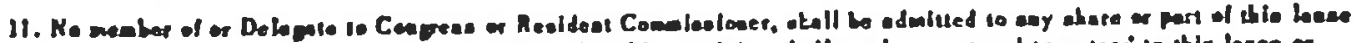

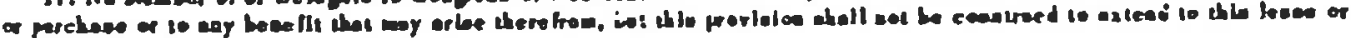

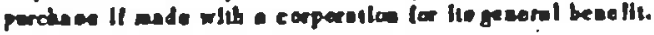

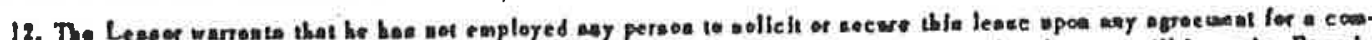

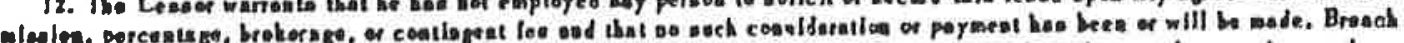

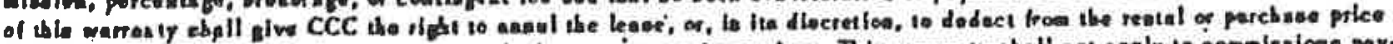

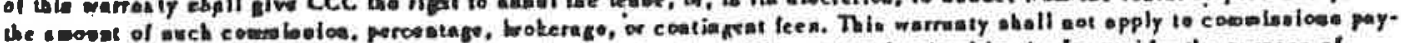

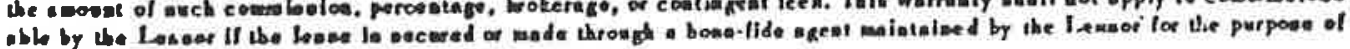
bastac ov eelling th poparty.

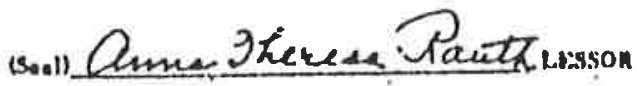

(Seal) Issson

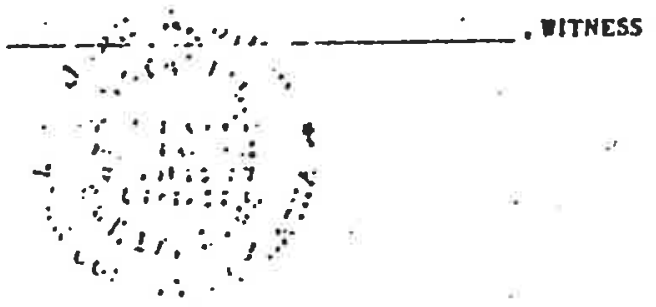

Signed in the preaenee of notery publle (j)

FEA A. STUHR chimantr ment covponation, us, is

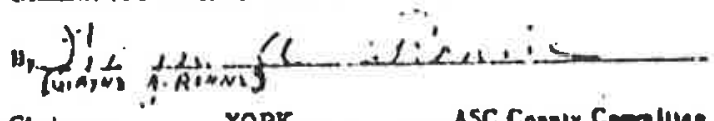

Clatrons. YORK Asc Conty Conelue Contracris a Utfices

\section{.771}

Maj 22, 1964

STr.it or AEbiRAKA

YLEH COUHTY $\&$

This inslrument was liled lor record on

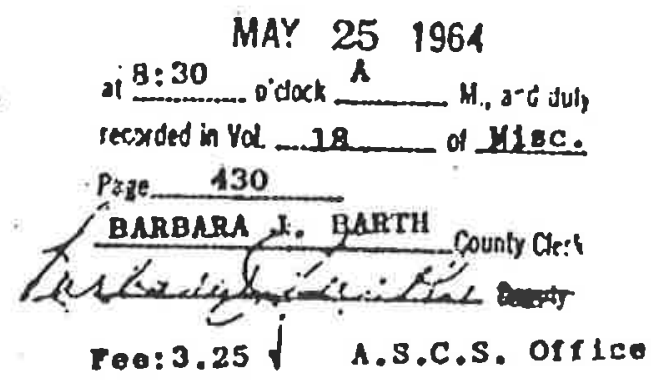




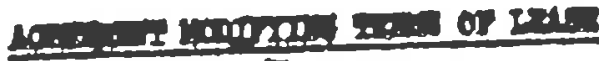

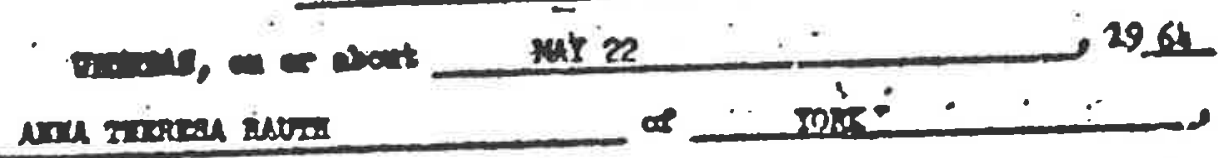

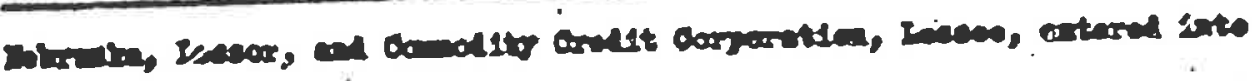

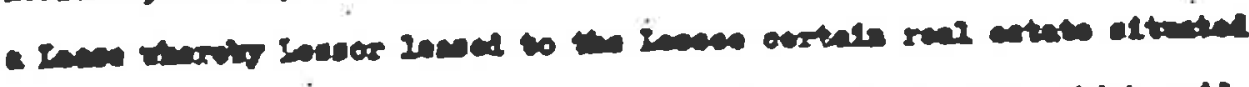
in in conts a Yorr

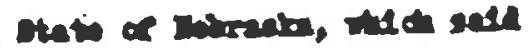

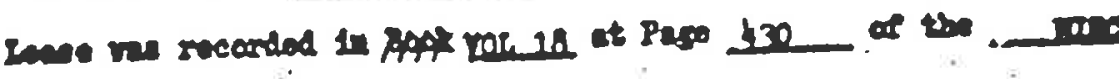
moeril at YONR conta, Talmeles ind

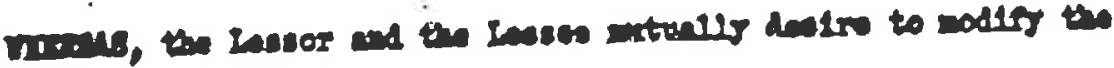

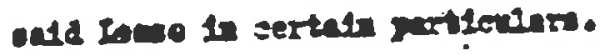

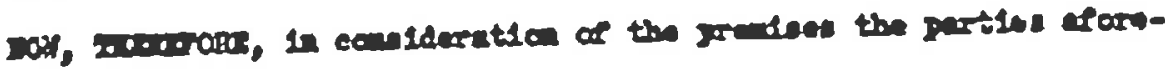

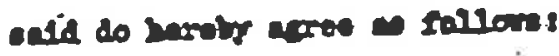

1. Mrotsin the 2ud ar a JATUARI 1967, 12

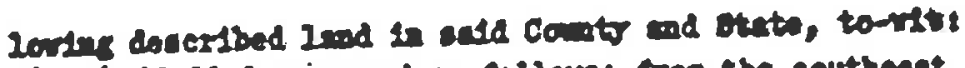

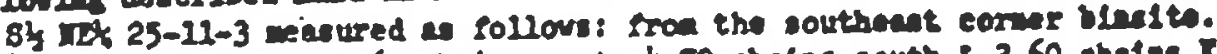

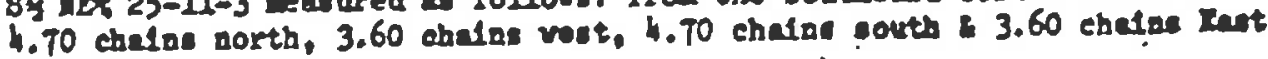

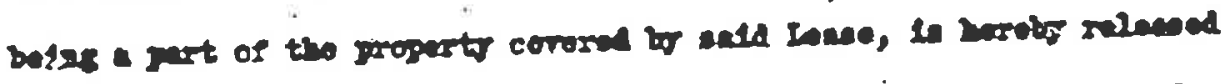

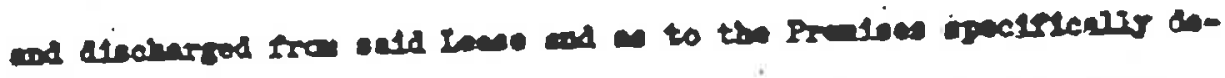

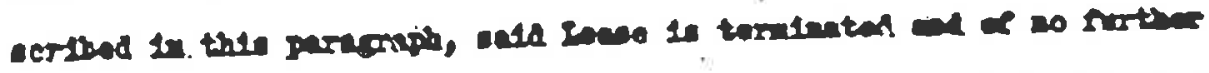

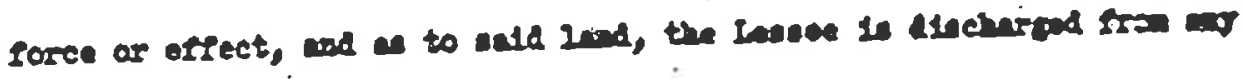

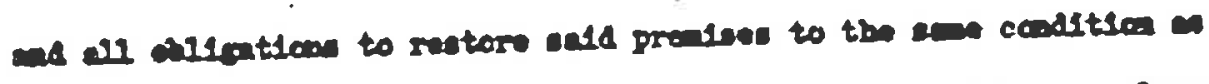

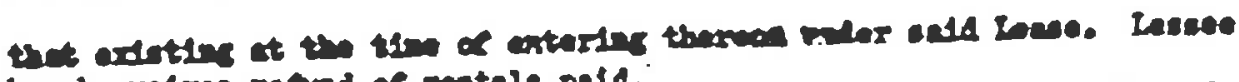
haraby valves refind of reatele pald.

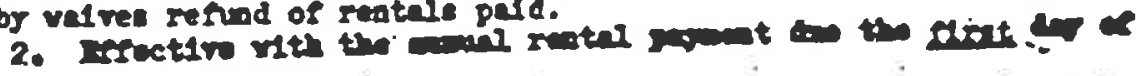
OCTORRR

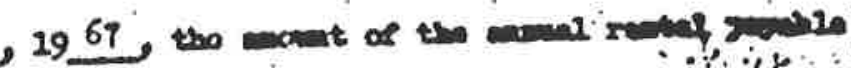

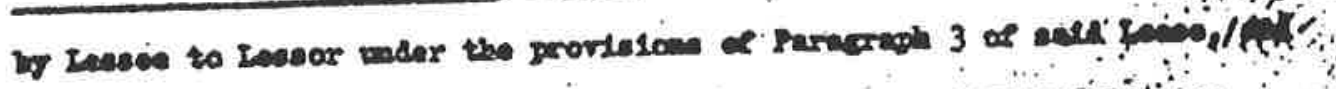

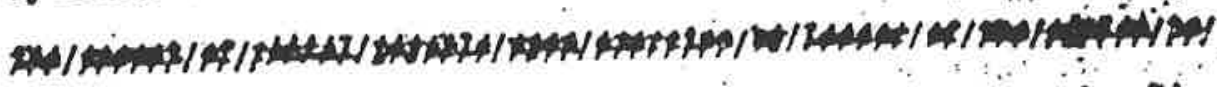

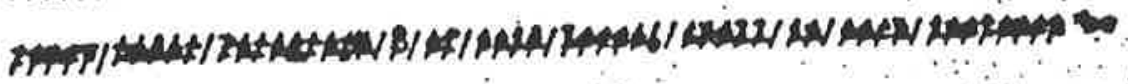

sran 230.50 to 246.00 sad the noure ecro rental peyable tpoe exerelse of the option to resen under paragrept of exid 18ese shall be $\$ 53.00$ par acre or $\$ 160.60$ per jear. 


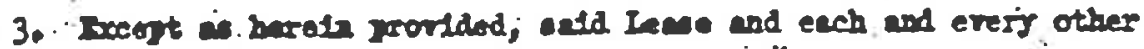

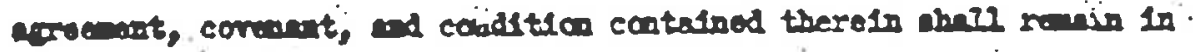
sill force ind oprect.

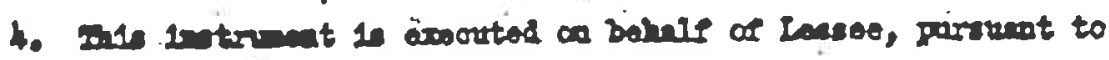

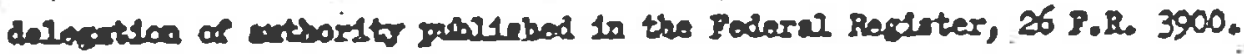

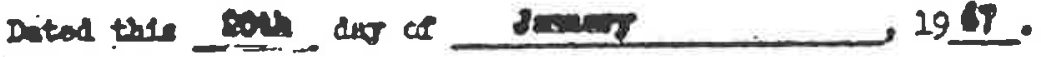

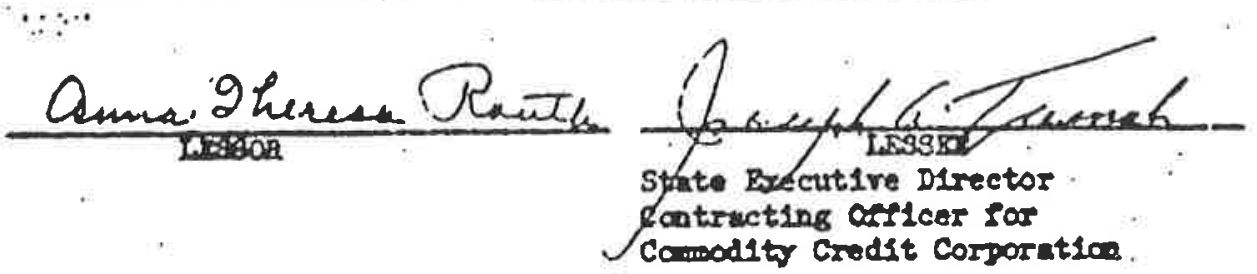

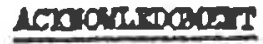

sertere or uneser $\quad\{88$.

conrs or $\cos$

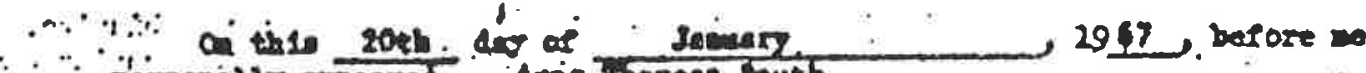
jareonals

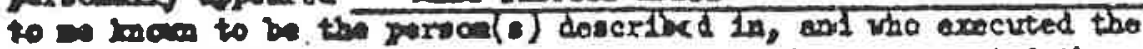

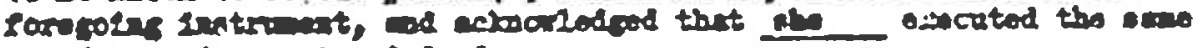

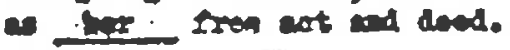

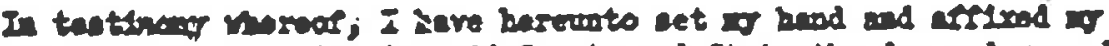

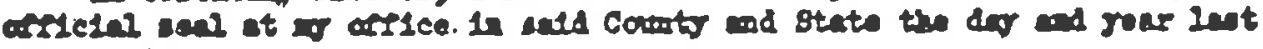
core werittain.

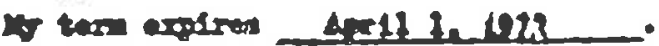

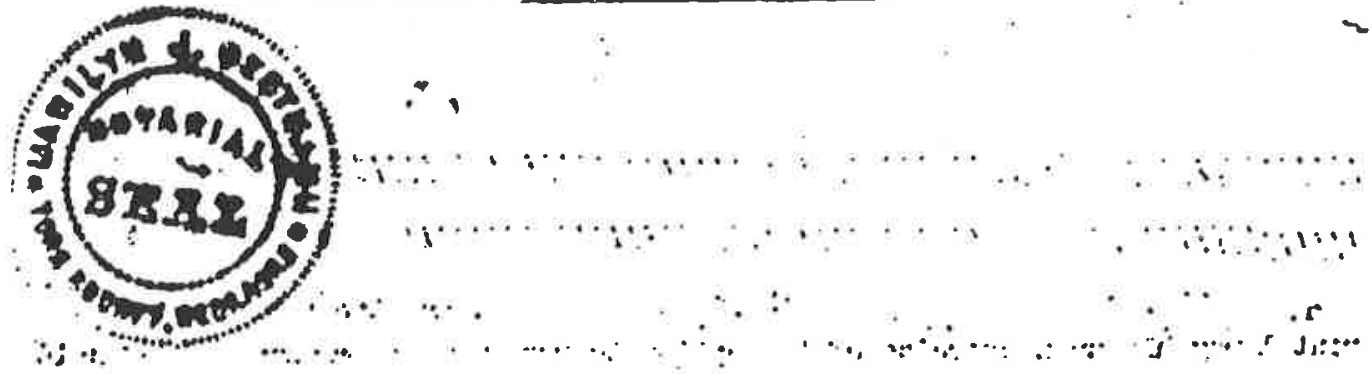




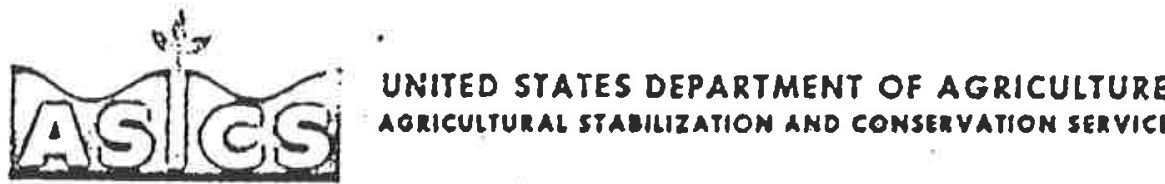

AGREENENT POR TERHINATION OF, SURRENDER OF, AND RELEASE OF LEASE

This agreement by and botween _ . . R. F.i Ind. , . . . … : : hereinafter called."Lessor", and comodity credlt corporation, hereinafter

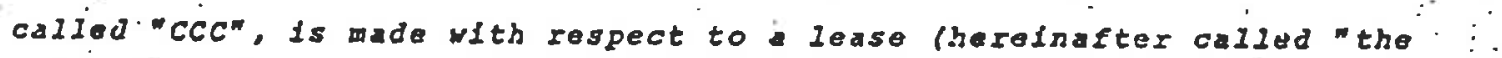
lease") heretofore ontered 1nto betwer Lessur ind CCC, whereby Lesaor Lotised to CCC ral estate stuated is the cousty of York, Nebraska, describod as follows

From the NB corser of the ShNEt 25-II-3 from center of road west. 3.60 chalnis, south $8.22^{\circ}$ chalns, eat 3.60 chalng and north 8.22 chaling. for an acrage of 2.95 .

the lease beling recorded In the offlce of the Register of Deeds in and for the courty of York. Nobraska, on.Pag. L6t, In Book Volume to, of the MIscellaneous Records.

NOW, THEREFORE, LESBOF and CCC do heroby agrea as follows:

(I) That the lease shall bo and same is hereby cancolled and teralcated effectivo the 29 th day of say, 1974.

(2) That lessor hereby waives and releases ccc from any further obligution to restore the premises to the same conditlon as that existing at the timo thit $C C C$ first entered upos the premises under the lease or. under any prior lease. 
(3) That Lessor shali retain all rent prevlously pald oy CCC, and that Lessor hereby releases CCC of all further obligation to make rent paymonts.

(4) This termination 18 executed on behalf of CCC puraunut to delegation of authorfty published in the Federal Reg1ster (26 F.R. 3900). COMSODITY CREDIT CORPORATION
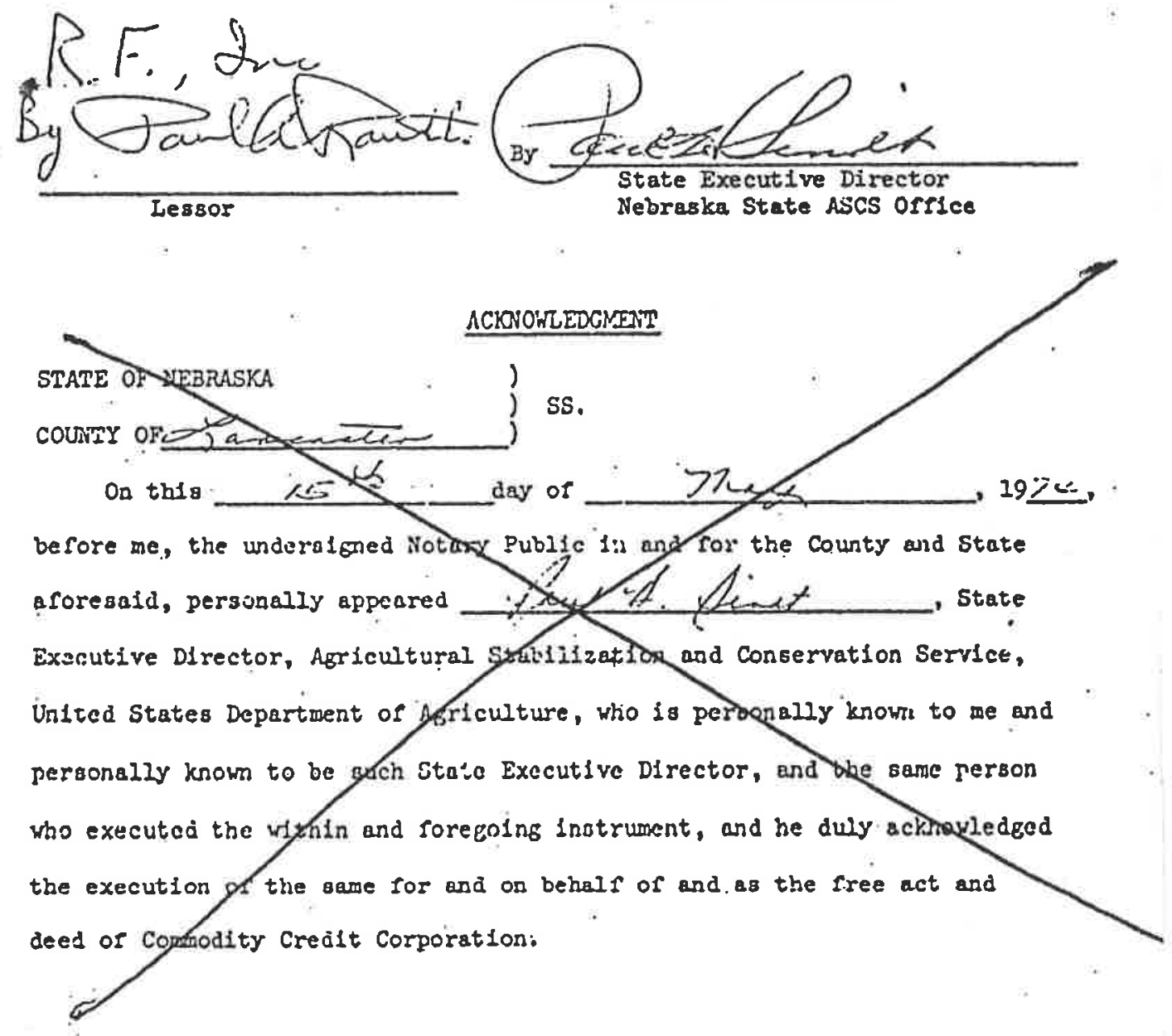
Copies of Titles

Former CCC/USDA Facility 


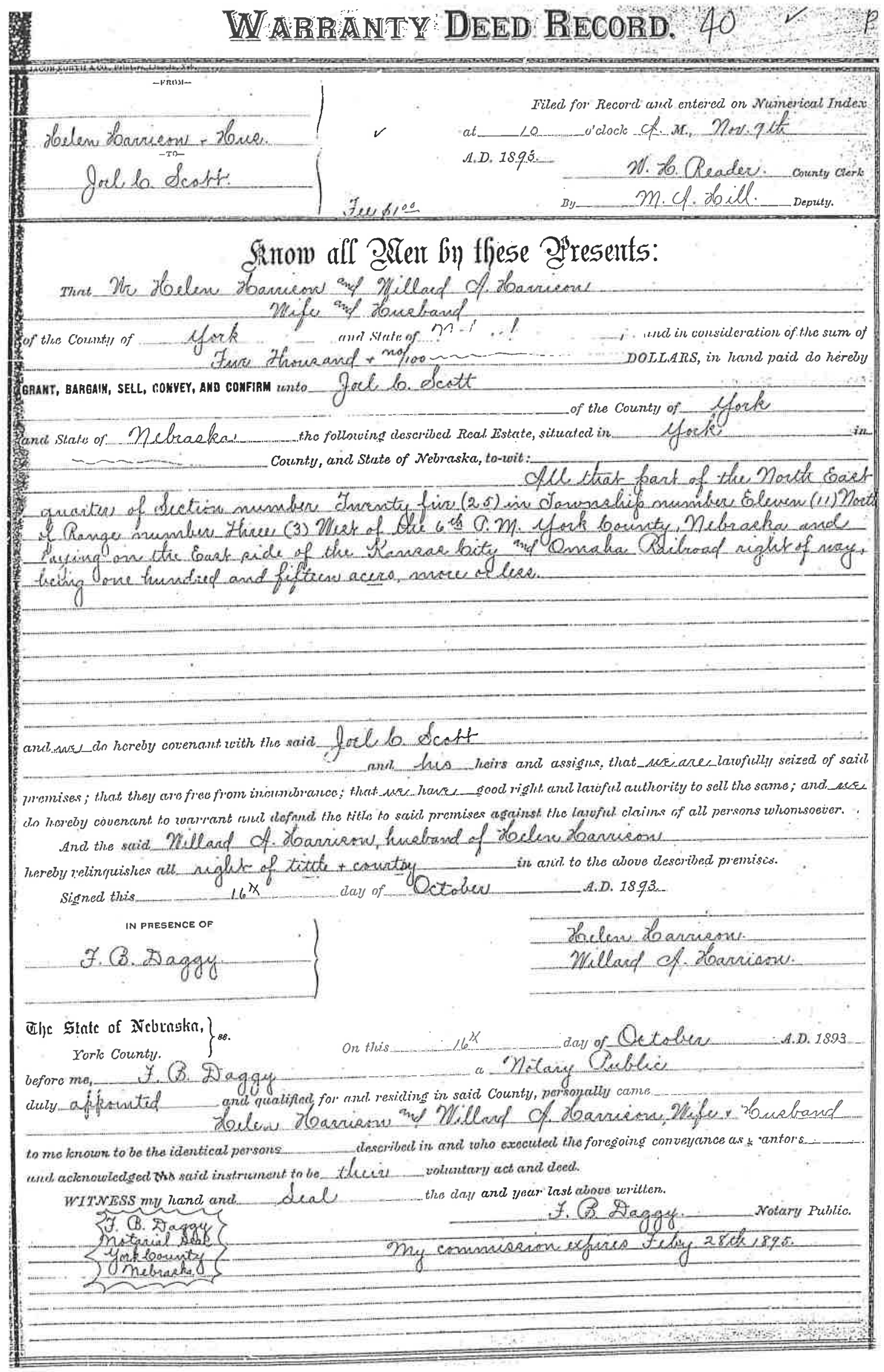




\section{WARRANTY DELD RECORD NO $60 \%$}

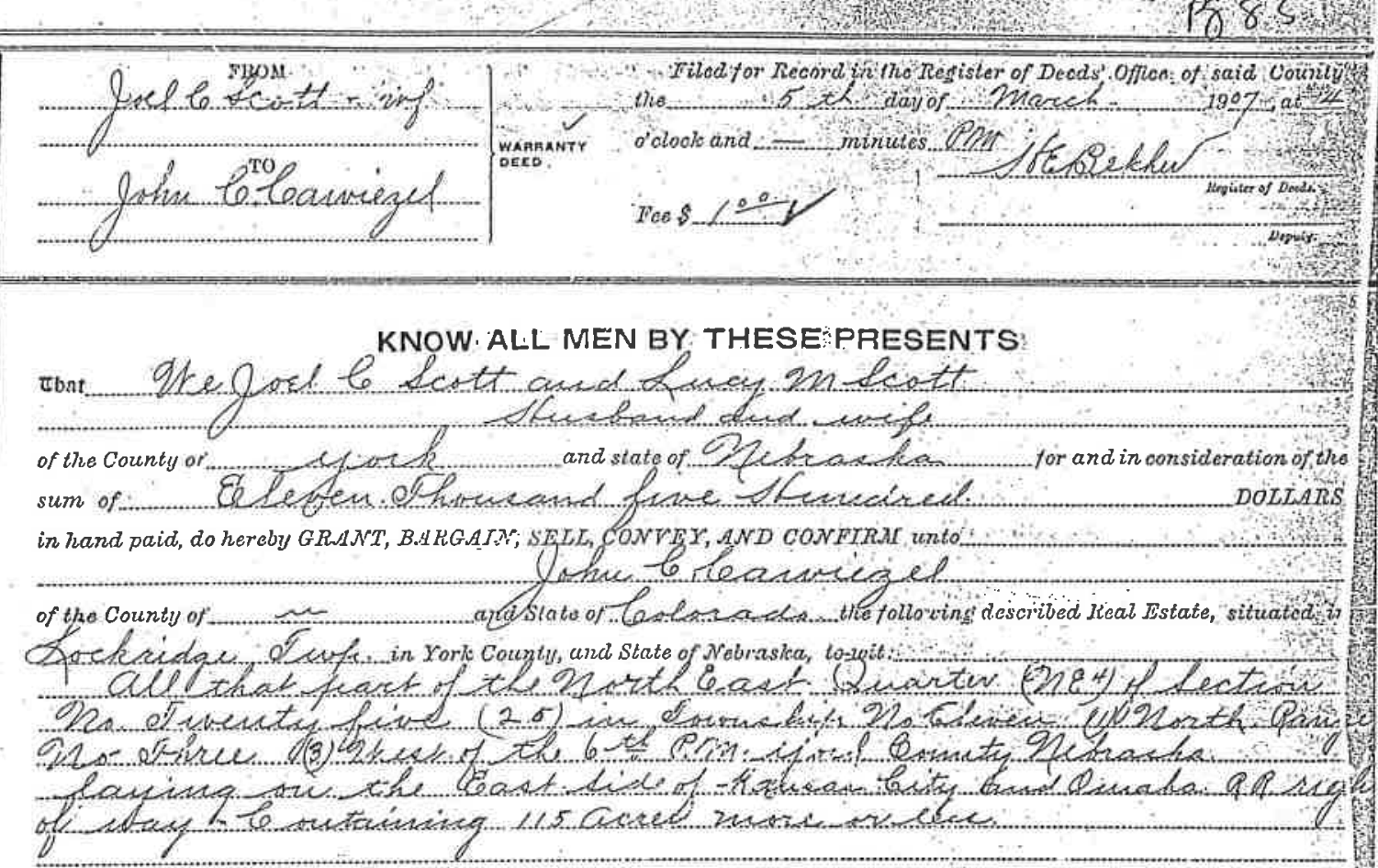

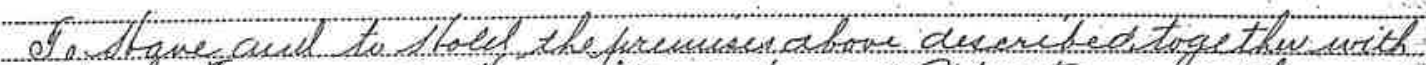

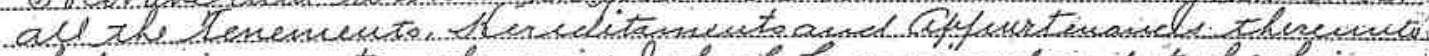

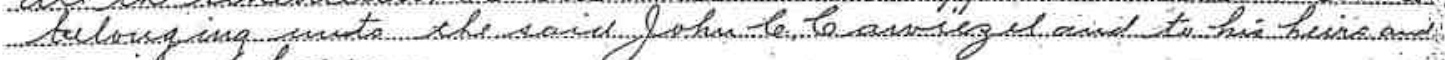

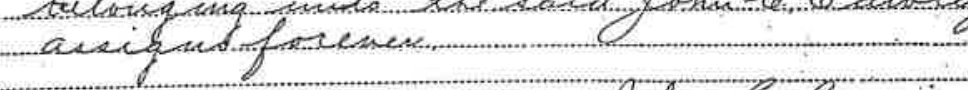

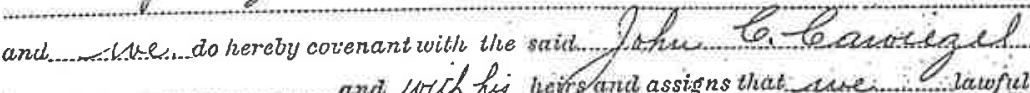

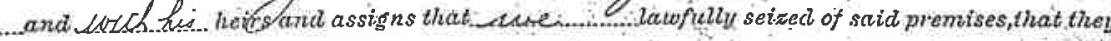

are free from incumbrance that dse have good right and lawfub

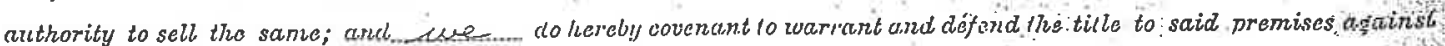
the lawful claines of all ner'sons whomsoever

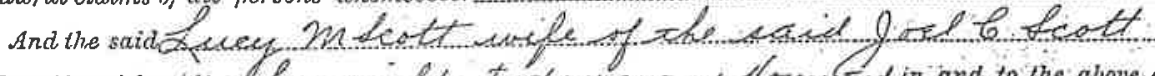

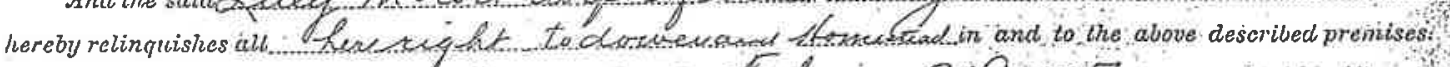
SIGNED this 1.2. .2. duy of ef

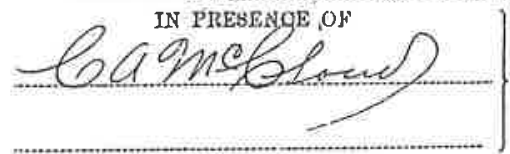

THE STATE OF NEBRASTA,

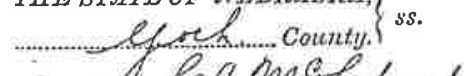

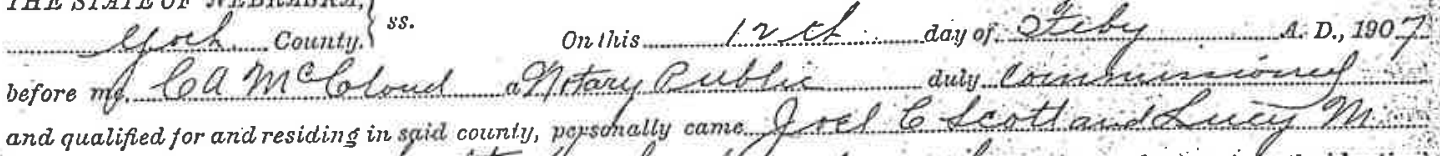

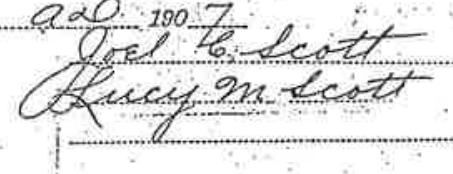

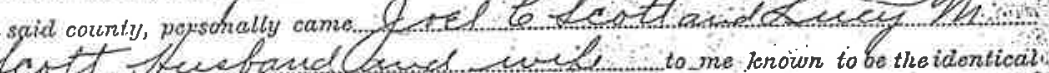

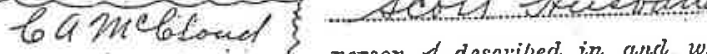
Notivial Horn bountas Sphaihary person.S.described in and who executed the foregoingi conveyanted us granto

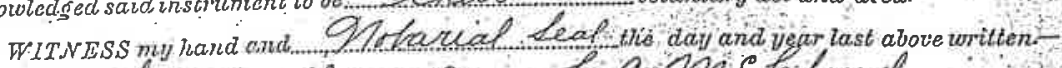
w 
John C. Cariezel is rife,

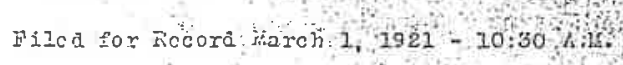

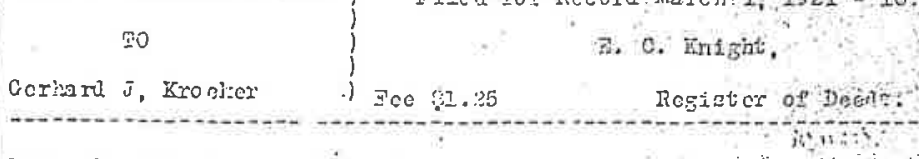

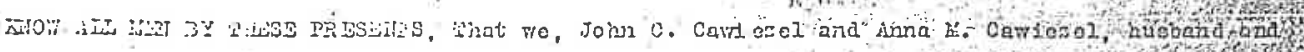

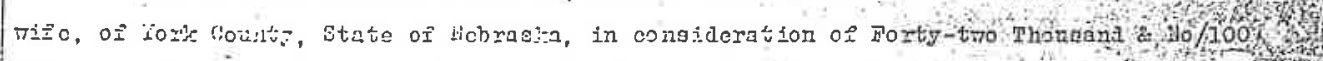

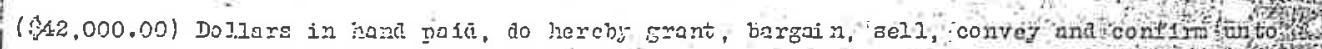

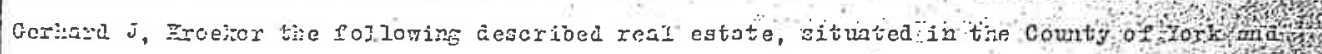

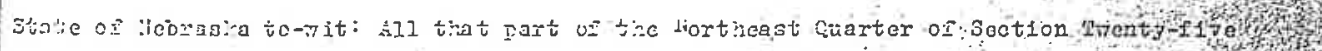

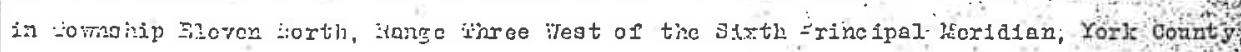

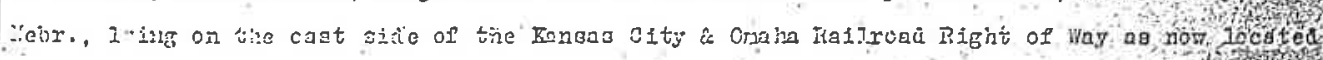

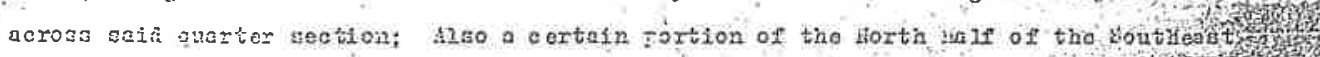

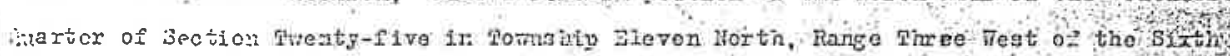

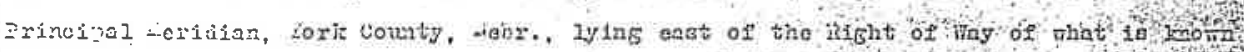

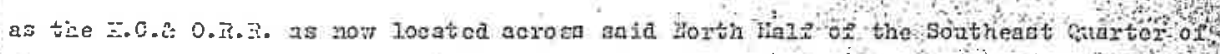

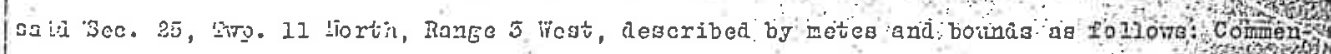

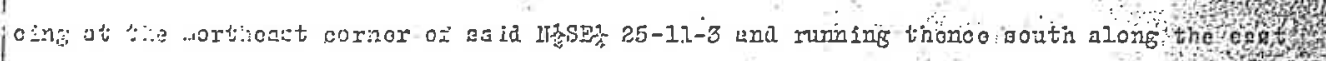
sibe of aic is

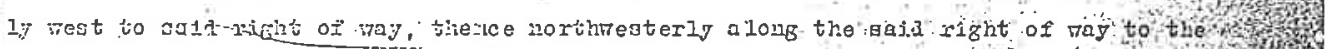

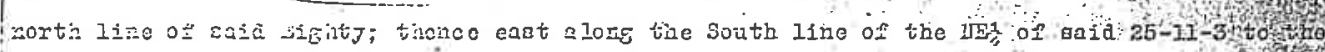

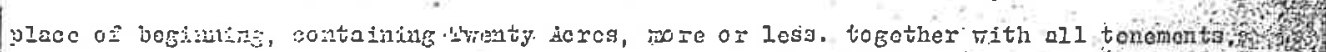

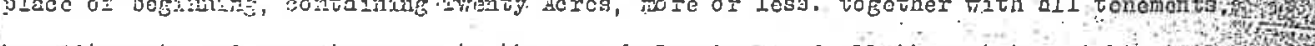
here:

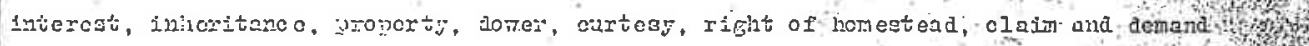
ihgtion over of : a

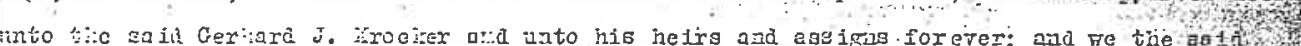

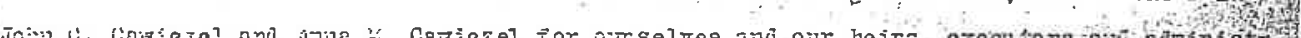

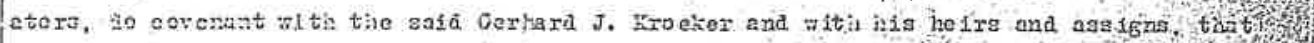

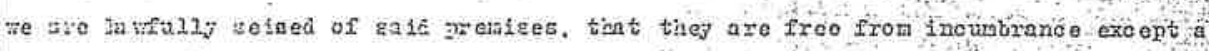

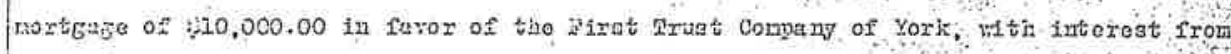

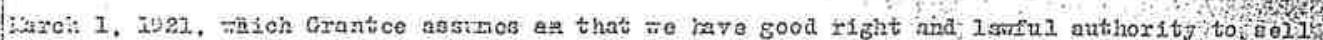

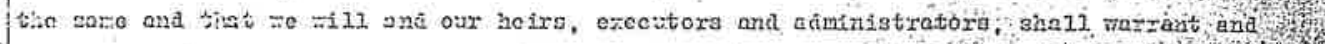

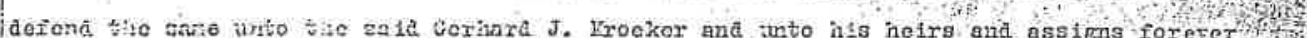

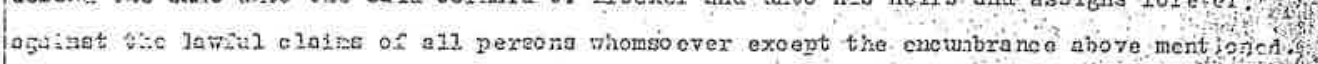

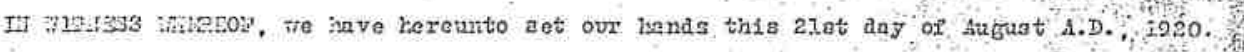
iiik 1093 :

o. A. Heztoud

Jom C. Camiezel

Anna स. Cariozol

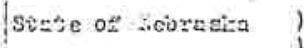

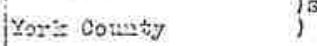

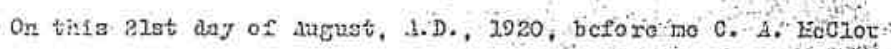

3.1. a notary public duly contiassoned and qualifiod for and root ar i

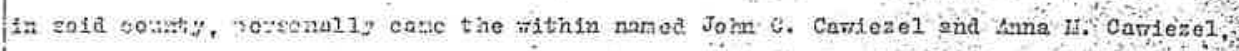

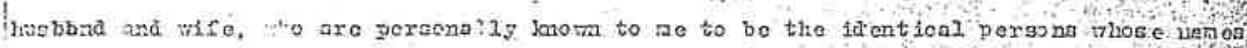

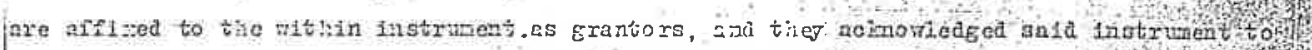
be their volimtary act and coed.

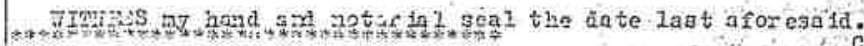

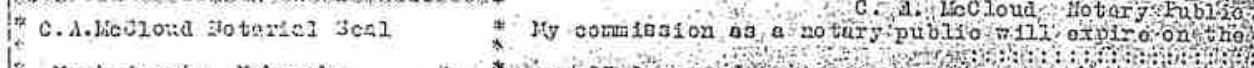
- a. locloud ilotory

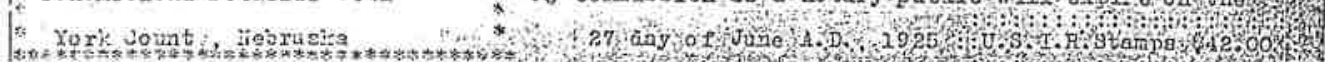




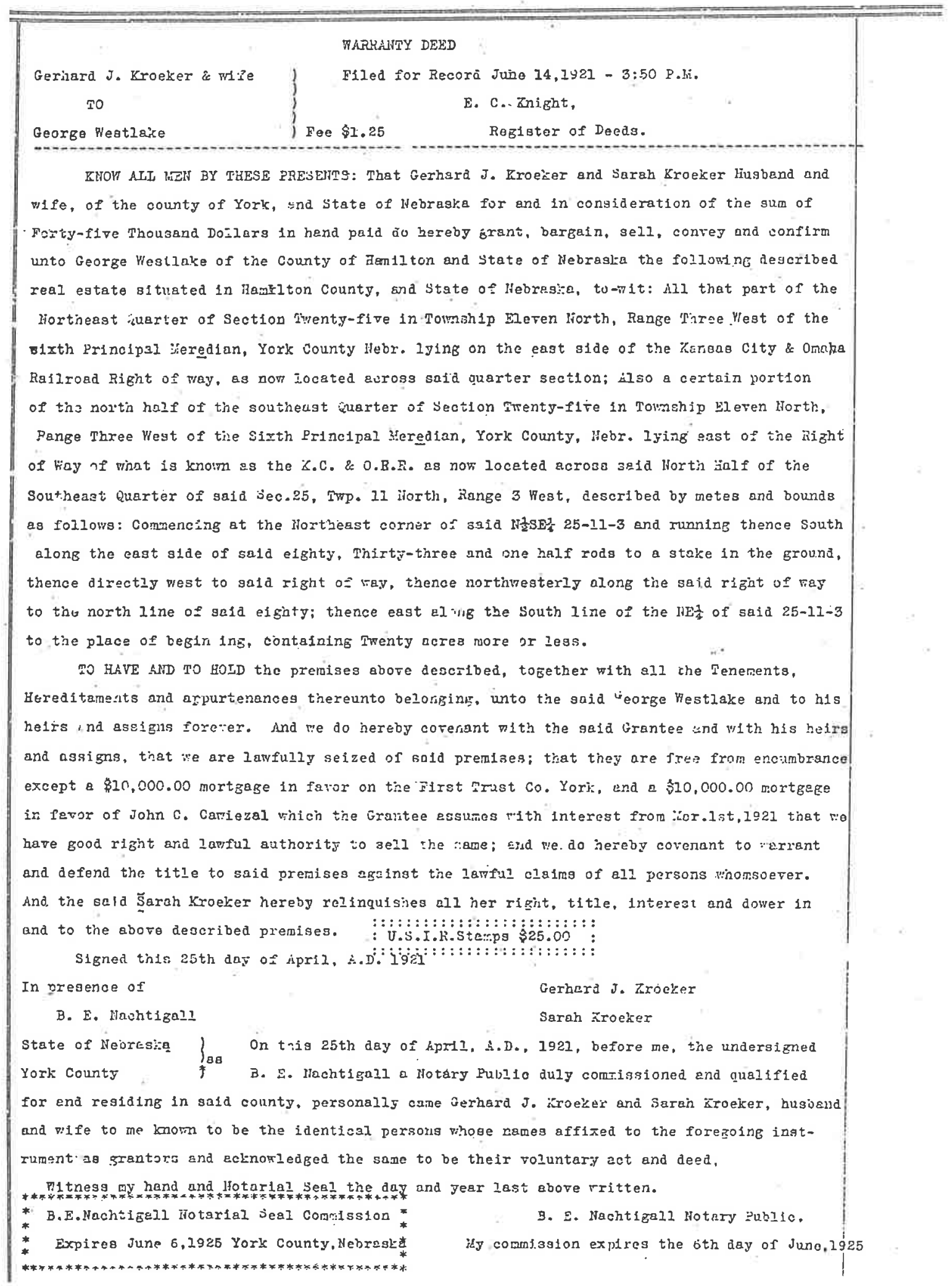




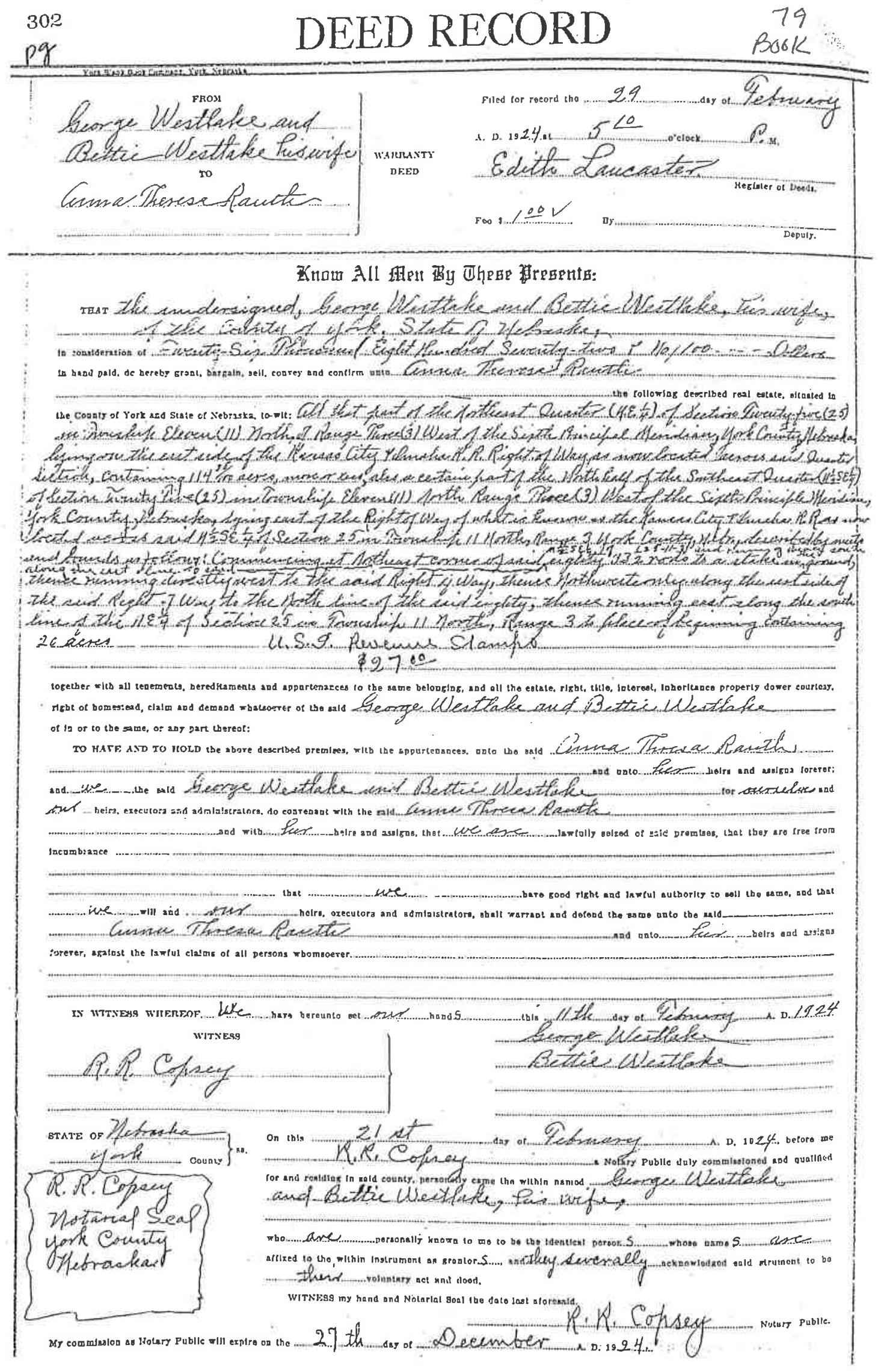




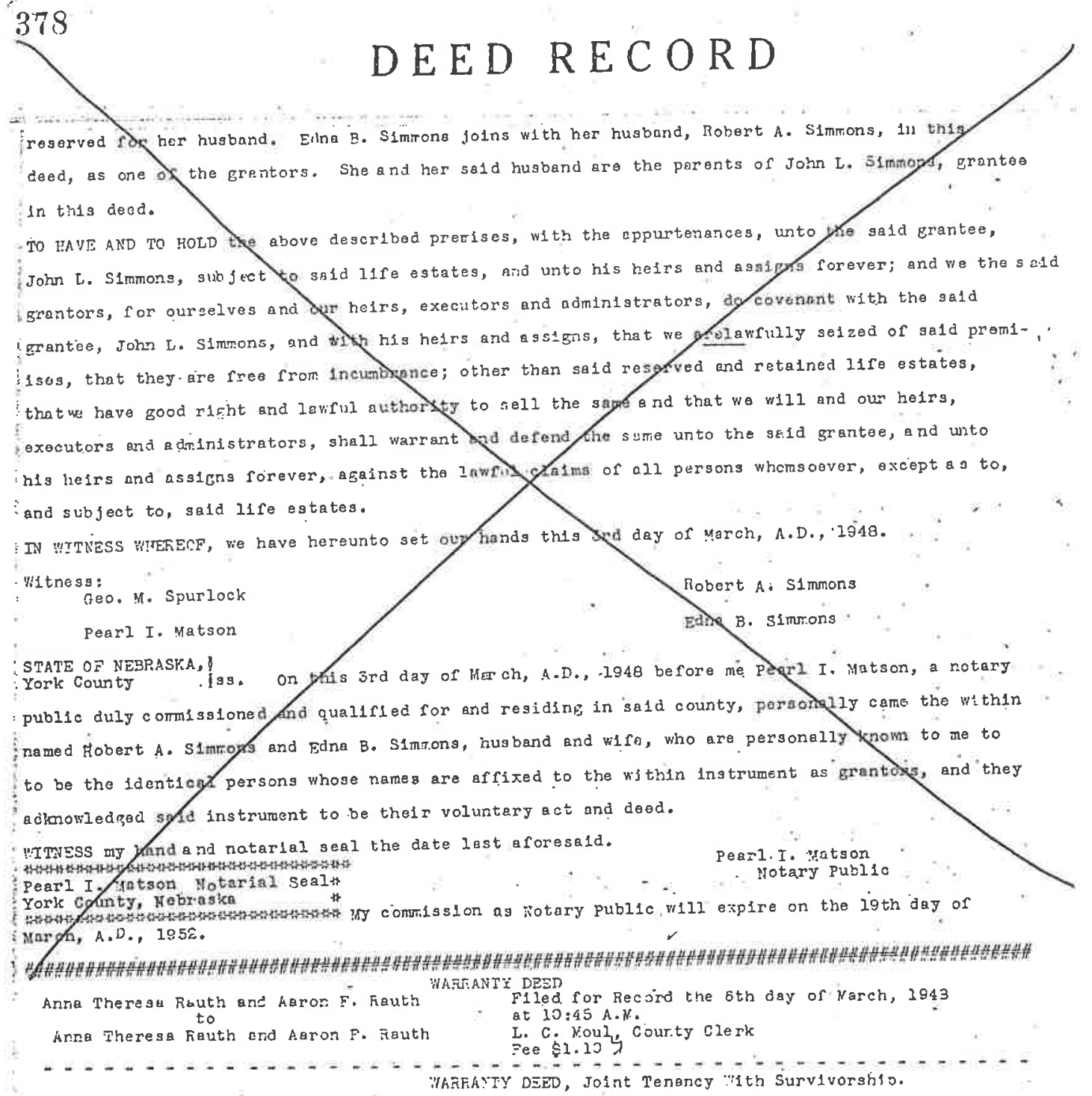

KNON ALI NEY: BY IIHES PEESEXTS:

That Anra Therega Rauth and Aaron F. Kauth, x. Se and husbanc, each in her or his orn rleht snd es the soruge of the other, of the courty or 5 r., State of lieiraska, for and in consideration

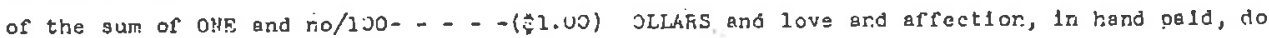
hereby grant, bargsin, sell, conveg and conel $1 \mathrm{~m}$ unto Aaron F. Rauth end Arna Theresa gauth, husbard and wife, of the courty of York, Stat of Kebreska, as TOTYT TEMhTS IITTH SIRVIVORSHP AND NOP AS TERANTS IN COMnON: the following o. ycribed real estate, situated in York County, State of Nebraska, to-nit:

All that part of the Northeast zuarter (riks) or Section Trenty-rive (25) in Tornsh10 Elever (11) liverth, Range Three (3) Test of the Sixth Principal Nerldian, York County, Nebraska, lying on the esgt side of the Kangas City \& Cauth R.R. Kight of llay as row locuted across alld zuerter secilon, contairing 214 jo/luo acres, more or less; also a

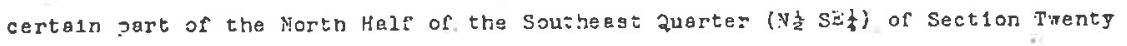
Flve (25) in Tounship Rleven (11) Forth Range Three (3) ilest of the sixth Prireipal Mer1ctan, York County, Nebragke, lging egat of the R'ght of Hay of what 1s known

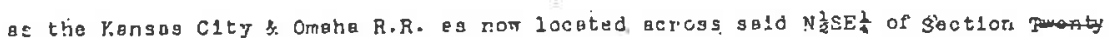
Five (25) in Tovinshlp (11) north Rance (3) York courity, thobr.. described by metes and bounds as follows: Comencing at the Northest corner of 


\section{DEED RE CORD}

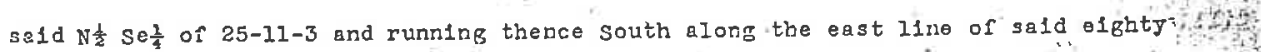
$33 \frac{1}{2}$ rods to a stake in the ground, thence running direclig vest to tho sala R1ght: of Way, thence Northwesternly alone the east side of the said Right of Way to the aty? North line of the sald elgity, thence running east along the south line of the NEt of Section 25 in Tornship 11, North, Range 3 to place of beginning, containirg 20 int: acres.

$$
\text { - and - }
$$

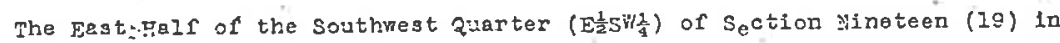
Townsh!p Eìven (11) NCRTH, sange Two (2) Fiest of the Sixth Principal Merldian, York county, Nebraska,

together with all the tenements, hereditaments, and appurtenances to the same belongling, and all the estate, title; dower, riht of horestead, claim or demand rhatsoover of the sald grantora, of, in or to the same or any'partr.thercor; subject to no exceptions.

IT BEI PRANTEES, TCT ENTIRE FEE SIMPLE TITLE TO THE REAL ESTATE DESCRIBED HEREIN STALI VEST IN THE STRIIVINC TRRTEE: (as provided in Section 76-1IE R.S. 2943).

TO HAV AHD TO HOLD the above desaribed premises, with tise appurteriances, unto the said

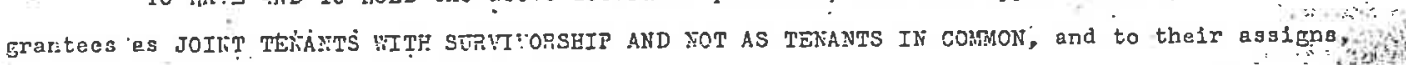

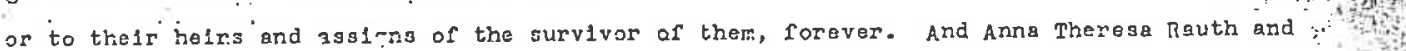
"Agron F..Rauth; the grantors nemed herein for themsolves and for their helrs, executors and adininistrators, do covenant with the granteos named herein and with their asgigns and with tho helrs and assions of the surviyor of then, that they are lawfulls selzed of suid prealses; that thoy are free from lncumbrence except as stated herein, and that they the sa10 grantors heve good richt and lawel authority to sell the sare; and thes do heraby covenant that they w1ll and : their heirs, executors, ond administrators shall warrant and defend the title to gald premiges unto the erantees narred borein end urto the1F assipns end unto the helrs and assigns of tho survivor of them, forever, agalnst the lewful clalms of all persons whomsoover, excluding the exceptions narod harein.

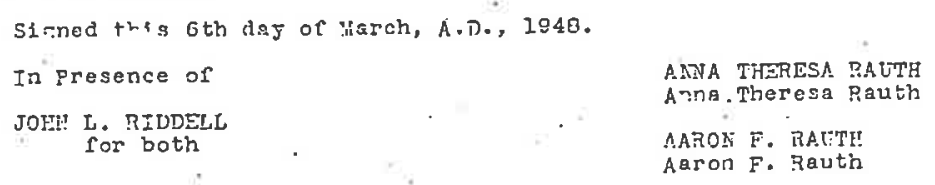

STATE OF NEBRASKA )

County of York. $\{$ ss.

on this Gth daj of March, A.D., 1948, vefore me, the uncersigned John L. R1ddell, a notary public, Auly comissioned and quelified for and residing in said county; personaliy came Anna Theresa Rauth and Aaron F. Rauth, wife anj husbend to me known to be the 1dentical parsong whose nemes aro affixed to the foregoing Instrument as grantors, and acknowledped the sald instrinelit to be their voluntary cet and dead. iit?rEs my hand and seal the day and gear last above written. 


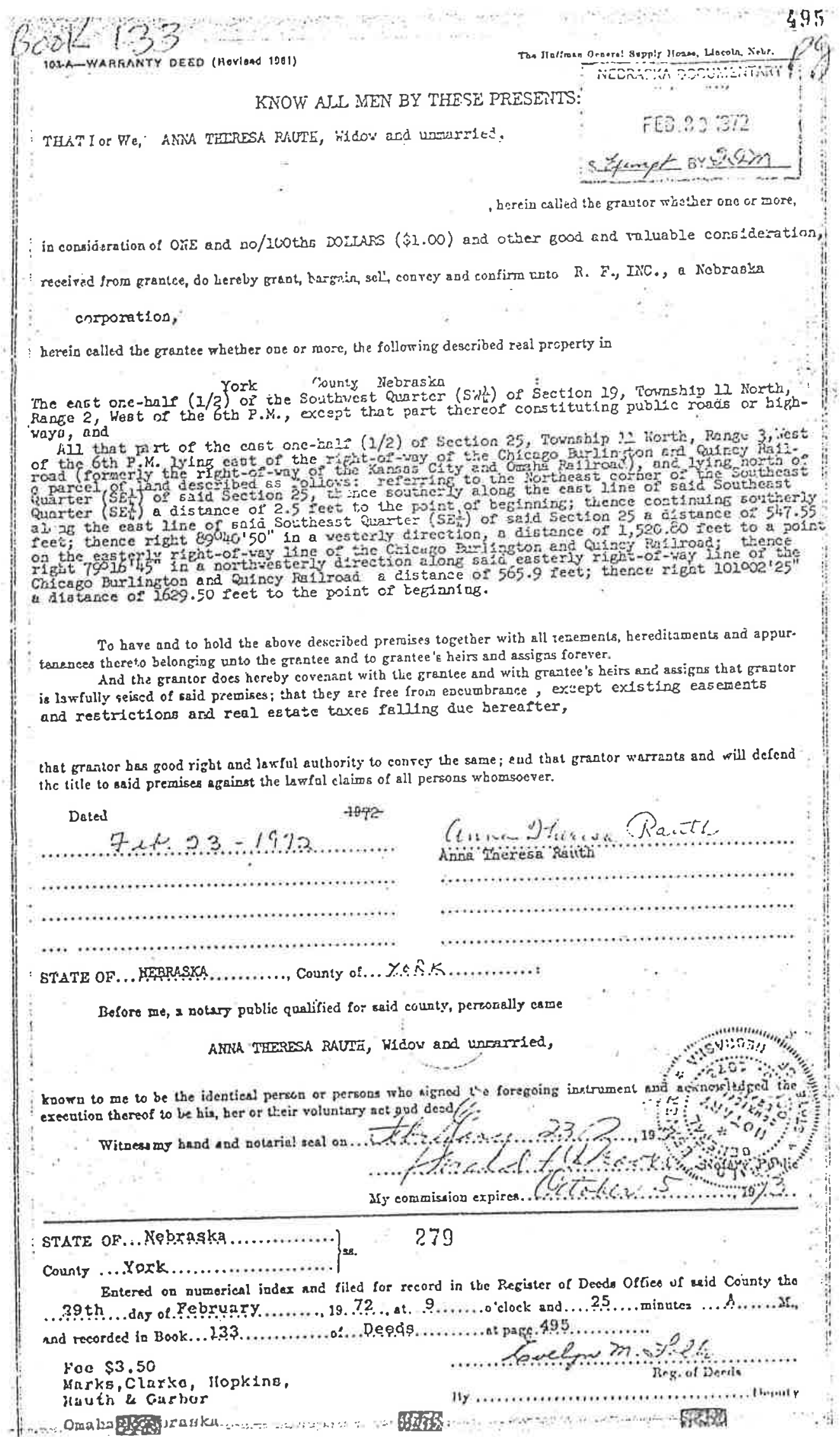




\section{W CORPORATION WARRANTY DEEDW}

- The erentor R. P., Inc.

a corjoration organized and existing under and by rirtue of the lawe of the Etato of Nebraska,

in consideration of One Dollar $(\$ 1: 00)$ end other sood and valuable consideration,

rôeived from grantoe, duen grapt, bargain, soll canvay and conflitm unto

Hermen I. Rauth, Trustee,

herein enlled tho kranteo whether one or more, tho following described real proports in

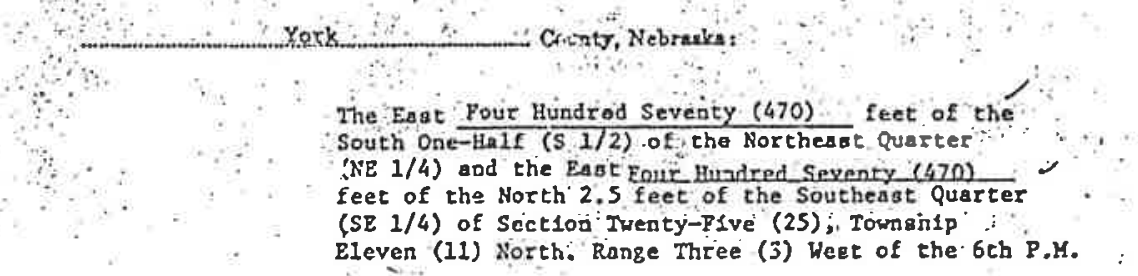

Eleven (11) Xorth. Range Three (3) Weet of the 6ch P.M.

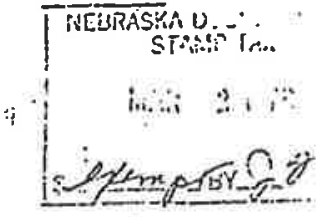

To hnve and to hold the above described presises togother with all tenementw, beredikments and eppirtcas:accen thereto belonging unto tho grantes and to grantee's beirs and aseigna torever:

And the grautor for itself and its successom does bereby corenint with the graviee and rith

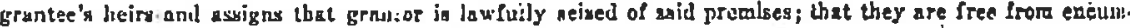
hrollies , iut subject to tenants' rights:

that grantor has good right and lawful-r.jthority to convey the samo; ngd that grantor warrants and $w$ defend the tille to sidi premines againat tho is wiol eleims of all peraone whososver.

- In witness whereof, granior bas hereunto caured ils corporato stal to bo afrized. and t:

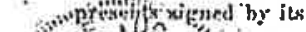

(3)

I. Diteit obrary 28. President.

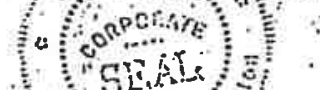

1978

$\therefore, 20, y=$

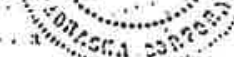

STATEOF NFBRASKA, County of

Before ine, a notarg public qualified in esid state pernosally eame Ph1lip J. Routh,

R. P., Inc., A Neb s. Corporation

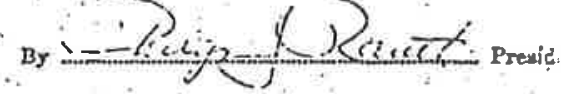

Douglas.............'

President

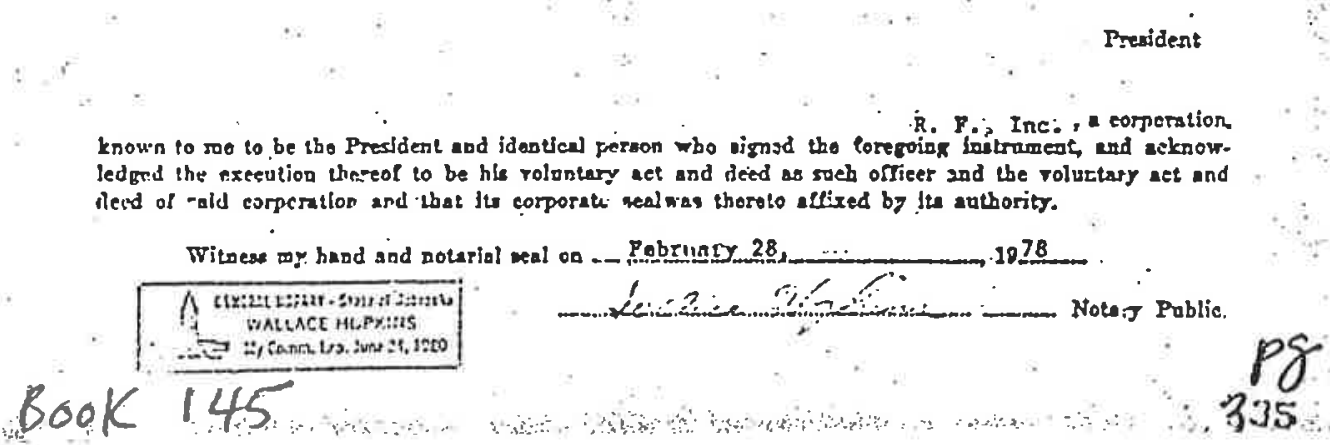




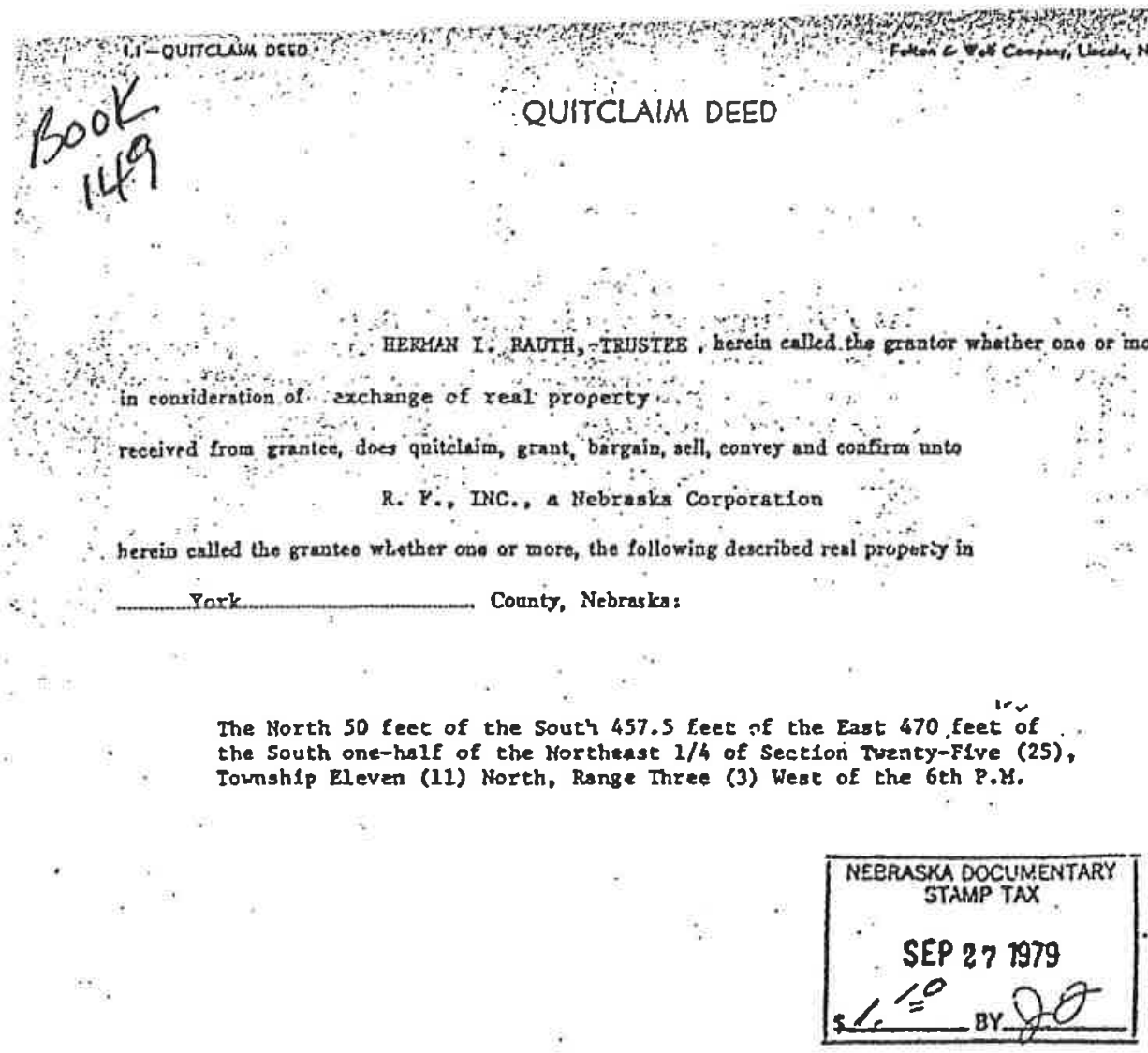

To hare and to bold tho aboro deseribad provises together with all tememosta hereditanente

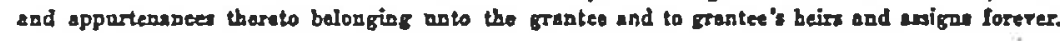

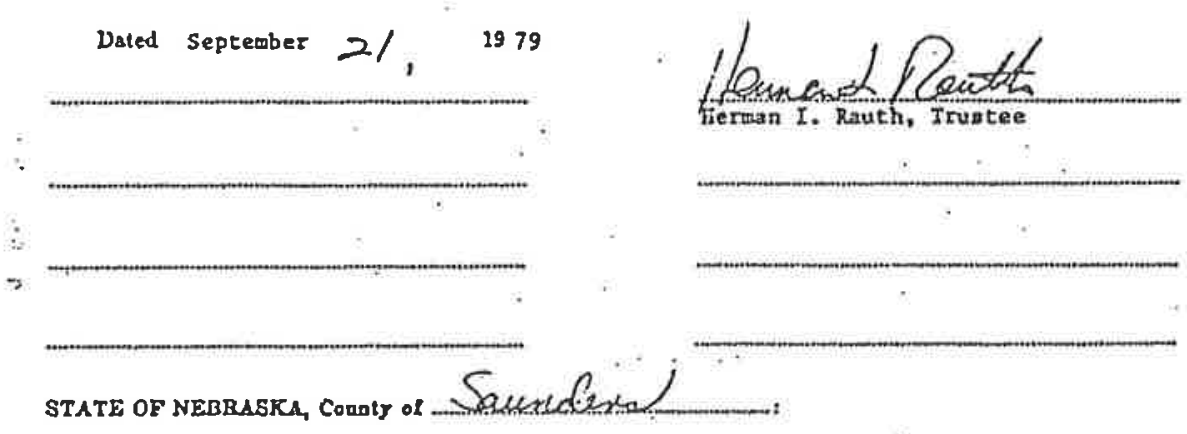

Before me, a Dotary publie quslitied lor anid counity, perzonally eame

HERUN I. RAUTH, IRUSTEE

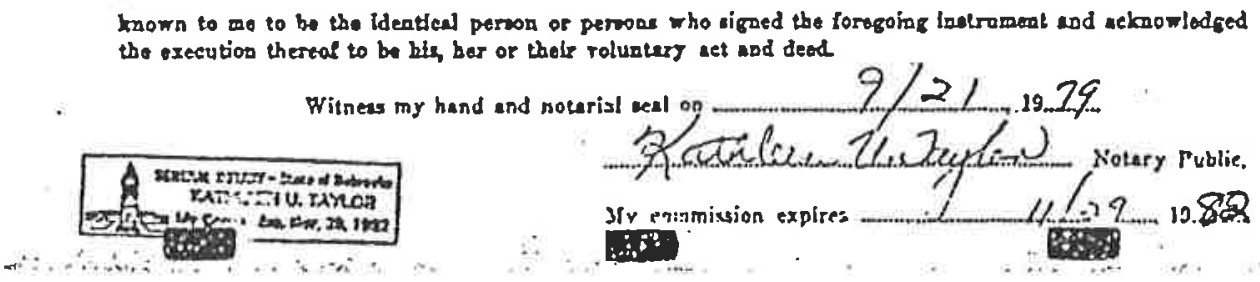



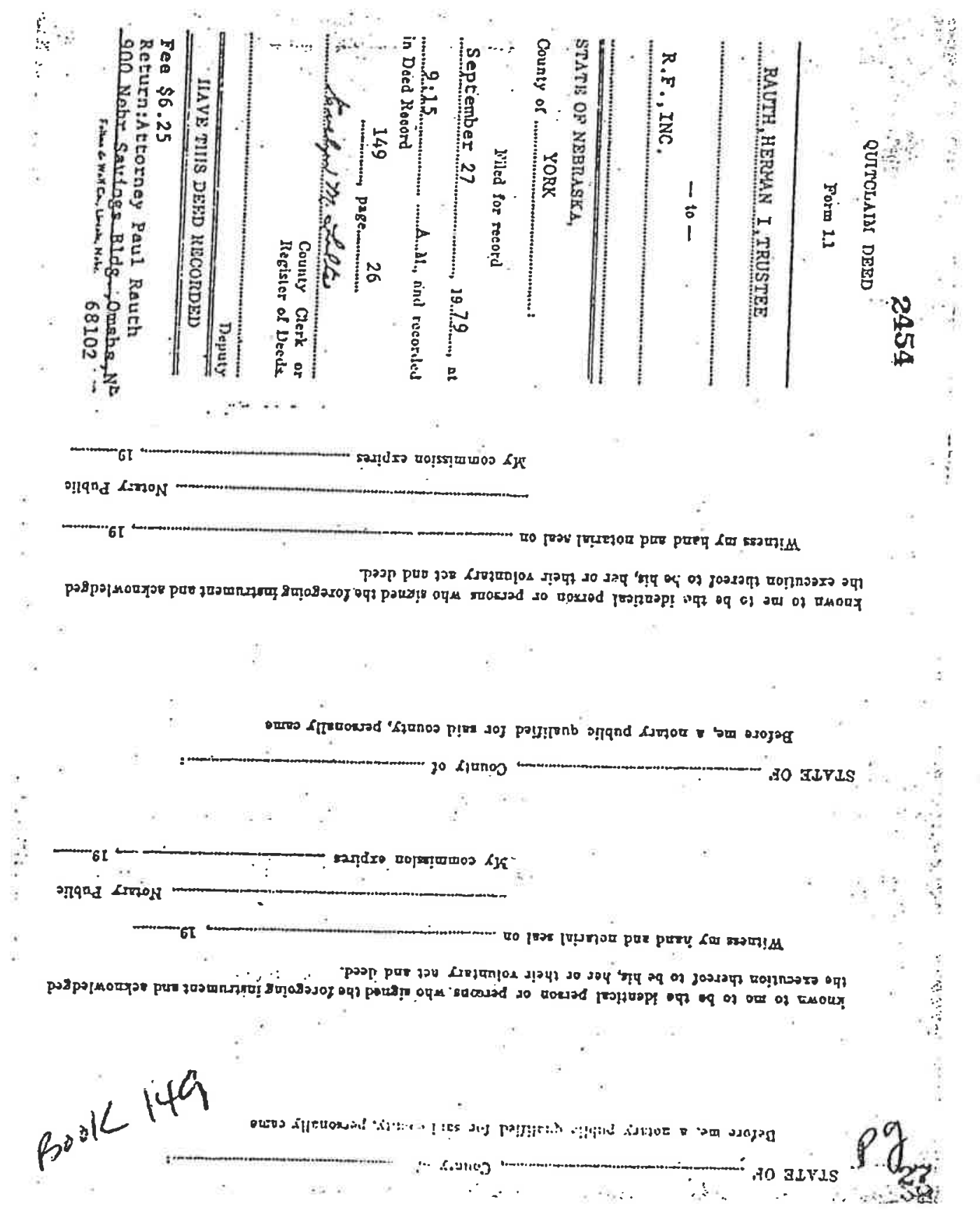


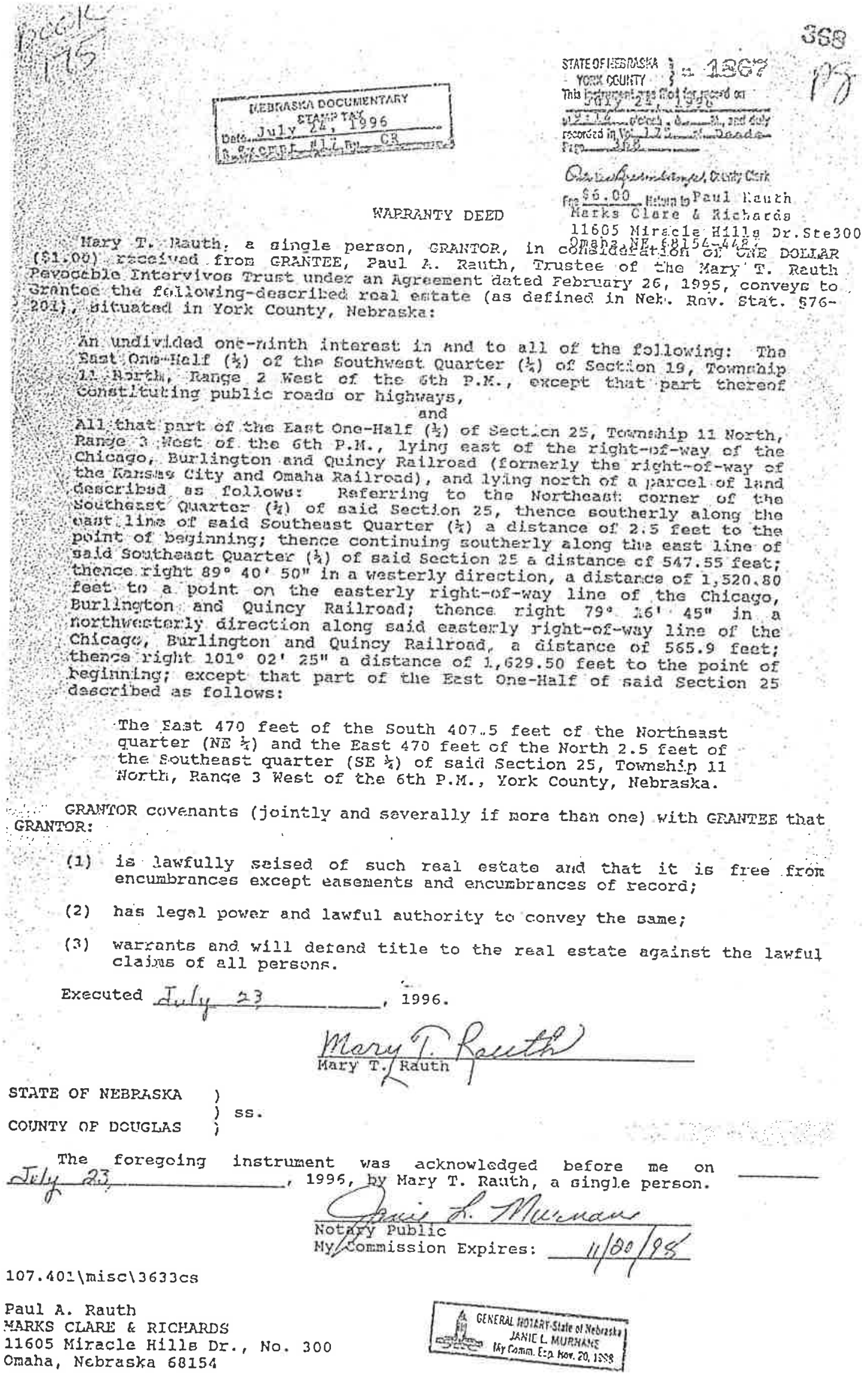




\section{Copies of Titles}

\section{Preslicka Residence}


HERTAN I. RAUTR, TRUSTEE.

bereic ealled the grantor whether one or more, in consideration of Ien Dollars $(\$ 10,00)$ and other good and valuable consideration rescived from grastees, does grant, burgain, sell enovey and confirm anto

METVIH G. PRESLICKA and CHARLOTIE G. PRESTICKA, Hustand and wife as joivt teasnts with right of anrrivorship, and not a tenants in comron, the following deseribed renl property tu Yark. County, Nistaska:

Commencing at a polnt on the East IIne of Sectlon 25, Townshlp 11 North, Range 3 West of the 6th R.M., York County, Nebraska, which point 1s 2.5 feet South of the cornerstond located at the Southeast corner of the Northease Quarter (NR 1/4) of sald Seition 25, thence West along a line 2.5 feet South of and parallel to the South Ine of the Northeast Quarter (NE 1/4) of sald Section 25, a distance of 470 feet. thence North along a line 470 feet Hest of and parallel to the Ease line of asd Section 25, a distance of 410 feet, thence East along a line 407.5 feet North of and parallel to the South 11ne of the Northeasi Quarter (NE 1/4) of sald Sect1on 25, a dlatance of 470 feet, to the East line of sald Section 25, thence South along the East IIne of sald Section 25, a distance of 410 feet, to the point of beginninz, containing 4.4 acres, more or less.

To have and to-bold the above deacribed premises cogether with all lenements, beredituments and epportenences thereto belonging anto the grantees and to their asigna, or to the beir and anigne of the aurvivor of then lorever.

And grentor does hereby covenant with the grantees and with their asagas and with the heirs and assigu of the arvivor of them that grantor is lawfully seised sf said premines; that they are free fron ercumbrace except roadways, and easements and restrictions of record,

that grantor bas good right and lawful authority to cocvey the same; and thst grantor warrants and will deferd the title to said premises against the lawful elaims of all persons whomsoever.

It is the intention of all parties hereto that in the event of the desth of either of the grantees, the entire fee simple title to the real estale eball rest in the surviving grantet.

D̈ated $/-3-$

198

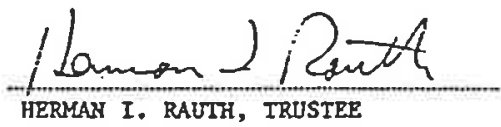

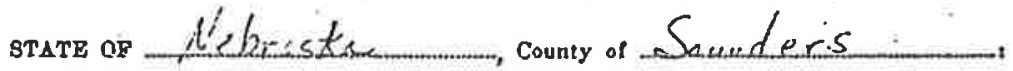

Before me, a notary public qualified for said county, personally came

HERMAN L. RACTH, TRUSTEE

known to me to be the ideatieal persou or persors who signed the foregoing instrament and ackowledged the execution thereof to bo bis, ber or their voluatary set end deed

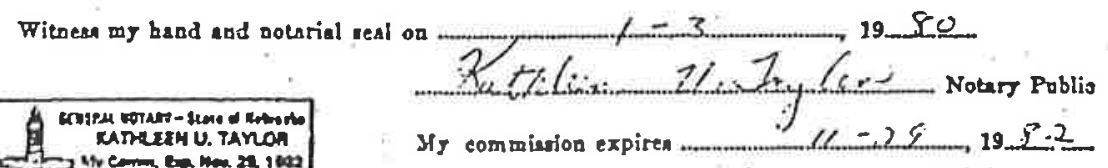




\section{Copies of Titles}

York Gun Club Property 
$46 C$

Warranty Deed Record

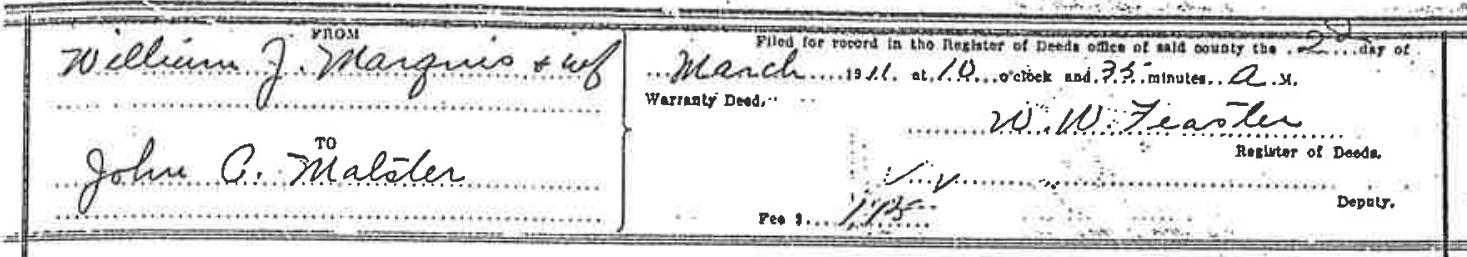

Tknow Fll Men tse these. Dresents.

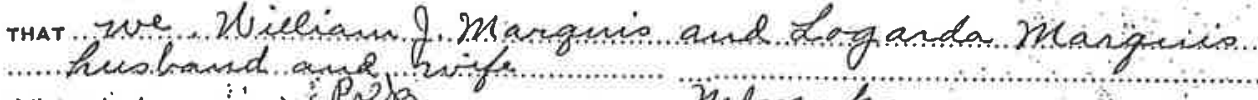

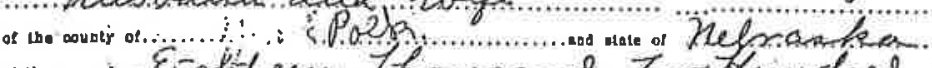

E....

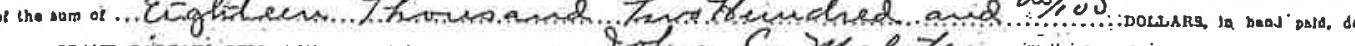

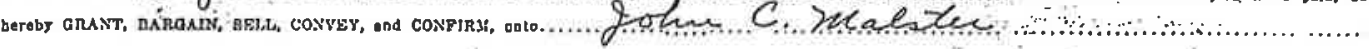

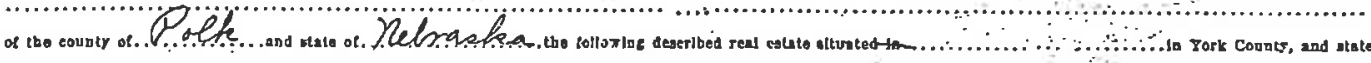
of Nebrarka toxit:

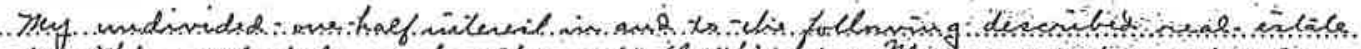

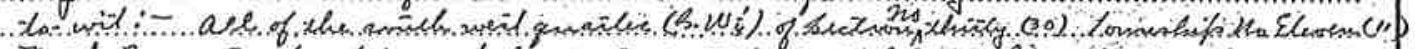

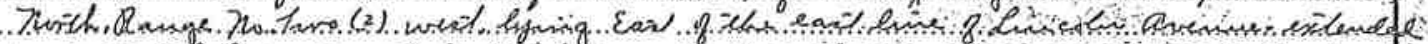

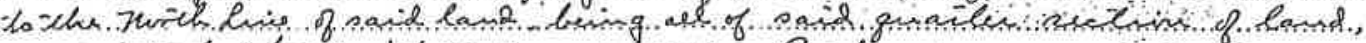
except that pail plated an Maleder Pails.

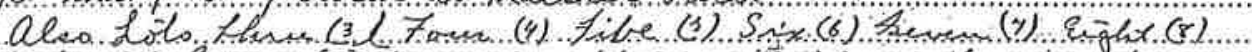

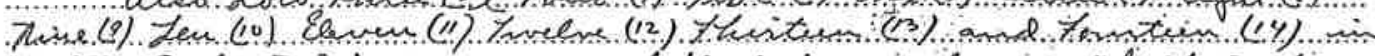

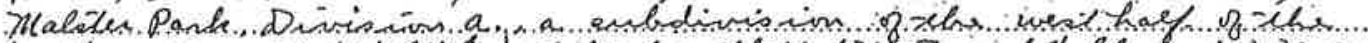

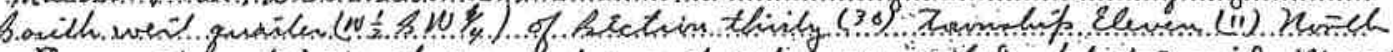

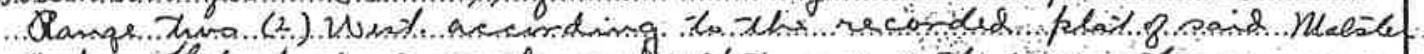

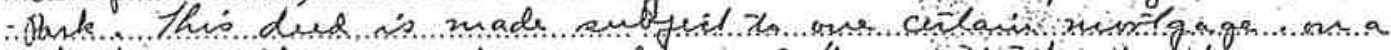

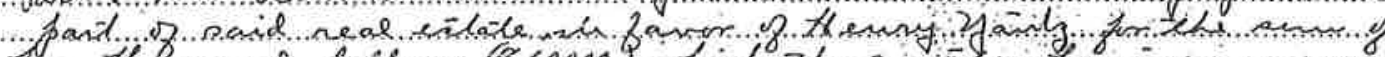

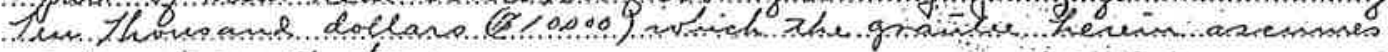

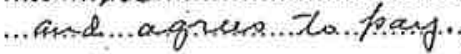

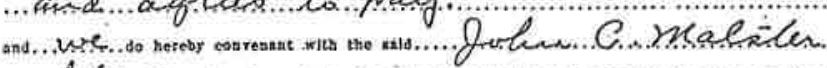

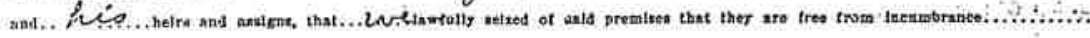

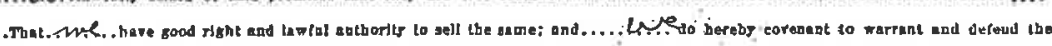

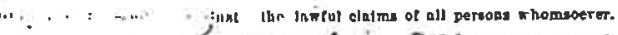

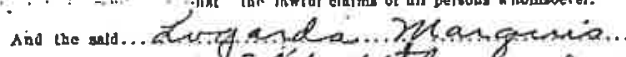

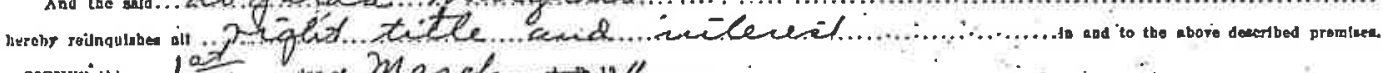

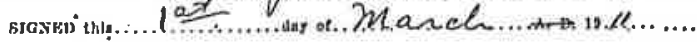

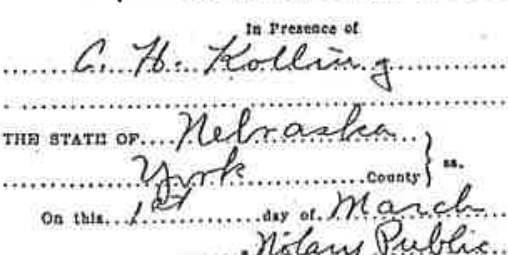

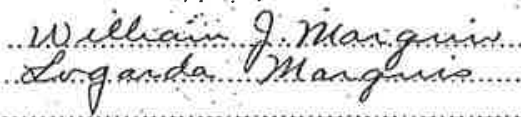

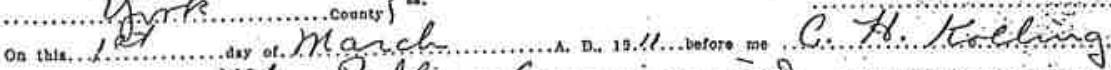

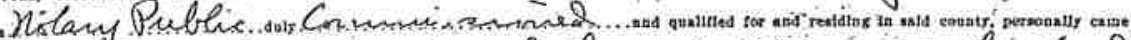

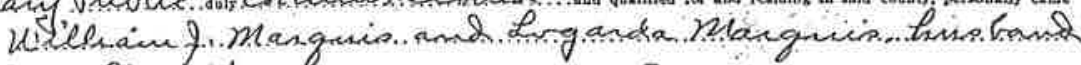

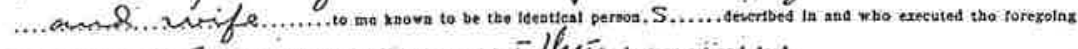

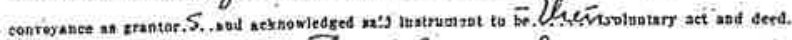

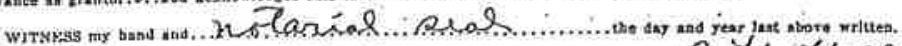

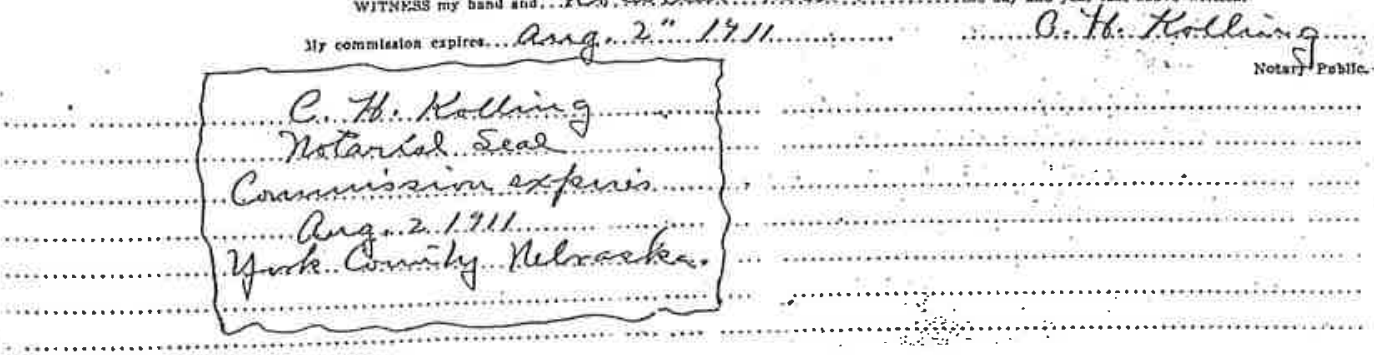


In York County Nebraska, w1 th all the appurtenances thereunto bolong1ng, to have and to hold

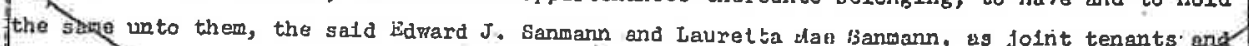

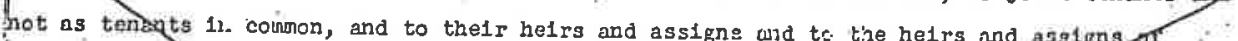
the survivor of them foraver.

It being the intertion of all parties hereto, that in the ovent of tyer death or elgher of sald zrantees, the entre ree simple title to the real estate fescribed herein shall vest in the surviving grantee.

In witness whereof, I have hexeunto set my hand this 25 th day of February, 1.936.

iritness: Hermann Glock

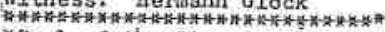
* Sal of the District Court, * York Ccunty liebraska

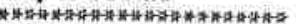
STALIS OF NEBEASKA

IOhi county J ss. On tins 25 day of Fopruary, 1936, before me, Eermann Giock, Clerk of the District Court, goly elected, qualifled and restaing in sald York County, personally appeared W. li. Wyghorf, referee, to me personally knovin to be the 1dentical person described in and who executed the foregoing, instrument of convey ance, end who acknowledged sald instrument fo be his voluntary act and doed " us such referde and for the uses and purposes thepein set rorth.

- iritnegs my hand and orflclai seal the lay and yeer last above firtten H H. H *S:-a) or the District Court* *York County Nobraska

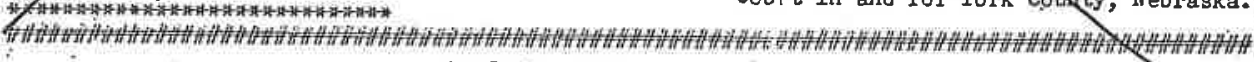

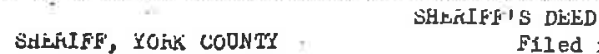

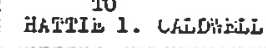
Filed for record ine 29; 1936 at 10:45 A.M. Edith Lancaster, Fegister of Deeds. SHeilk'is DEkD

Kison ALL Hed BI Tifsic PfissidTs: That whereas; at the January 1933 term of the District Court of York County, Nebraska, in a case pending in sald Court wherein Clarence G. killer and Lethe $\mathrm{b}$. hiller ere plajntiffs, and Katharyn Shaneyielt, et al., are defendants, the sald plaintiffs obtalned a decree on theiz petition for the sum of' Fourteen 'Thousand one hundred seventy elght and $76 / 100$ (\$14,178.76) Dollars, with interest thereon from February 4, 1933, at the rate of efght per cent per arinu, us a flrst 11 en on the real estate bereInarter described;

ino iheress, $1 \mathrm{t}$ was then and there further ordered in saio action that in default of the pajment of the amounts so fcund due, the real estate described in the plealings in sald acticn be solid as upon executicn to setisfy said decree;

And ithereas, there hiving been default in the paymen: of the amounts menticner in seic decree, A.E. Cartor, bherifr or York County, Nebraska, inder and by virtue of an order of sale to hla directed, 0.1 the 27th day of February, 1934, at one o'clock P. H, at the rest Front door of the courthouse in the City of Ycrk, York Connty, Nebrasieg (thut belng the place where tha last terif of the Distrlet Court of suld County was held), arter hav1ng blven due and legal notice of the time and place of sald sale by pululcation for not less than thlity. days prlor thereto in The New Teller, a weekly legal aensppper, printed, published and of beneral circulation In York County, Nebraska, sold ih a sald roal estaje to liattle I. Culdwell (rormerly Hattle 1. ufller) for the sun of Fliteen Thousand Seven Iundred Serenty-f1ve and Ho/100 (\$15,775.00) Dallars, sald purcheser being the highest and best bidder therelor;

And thereas, saic sale was afteriards at the September 1935 term of sald Court duly exantined and confirmed by sald ccurt and A.k.Carter, as such sheriff, oraered anc directed to make a deed conveying sald real estate to tine purchaser; 
Now Therefore, in consideration of: the premises and the sum of Fifteen Thousand Seven Hundred Seventy-f1ve and No/100 $(\$ 15,775.00)$ Dollars, so b1d and pald as aforesald, I, A.E. Carter, Sheriff of York County, Nebraska, do bereby grant, sell and convey un to Hatt1e I. Caldrell (formerly Hattle I. Hlller); her helrs and assigns forever, the real estate so sold

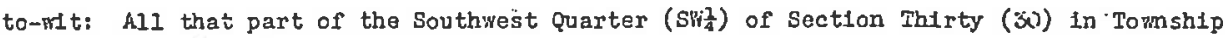
E'leven (11) North kange Two (2) West of the 6 th P.M., winch 1 s not platted as "Malster Park, Divisior: Al, and also Lots Three (3), Eour (4), Five (5), Six (6), Seven (7), Nine (9), Ten (10), Eleven (11), Twelve (12), Thirteen (13), and Fourteen (14), Ualster Park, D1Fisicn A, all in York Couinty, Nebraska, according to the recorded plat thereor,

To have and to hold said real estate with all the appurtenances thereto belonging, to the I sald Hattle I. Caldwell (formerly Hattie $I$. Mlller), her heirs and assibns forever:

In whtness whereof, I have hereunto set my hana th1s 7 tin day of February, 1936. iiittness: Bermann Glock A.E.Carter, Sherlff of York County, U.S.I.K. BIR⿴囗十 $\$ 16.00$ Nebraska.

State of Nebraska

York County fs. On th1s 7 tin day of Februars, 1936, before we, Hermann Glock, Clerk of the Dlstrict Court, duly elected, qualifled and reslding in said York County, personally appeared A.E.Carter, Sherlff of sale York County, to me personally knom to be the 1der, itcal person described in and who executed the foregoing instrument of conveyance, and who acknowledged sald instrument to be his voluntary act and deed as such sheriff and for the uses and purposes therein set forth.

hituress my hand and offtclal seal the day and year last above written. * * Seal of the District Court York.County Nehraska \#

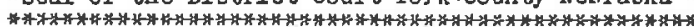
Hermann Glock, Clerk of the District Court DHA

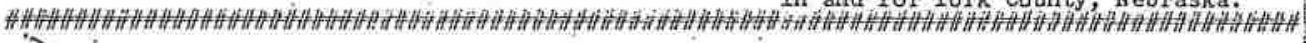

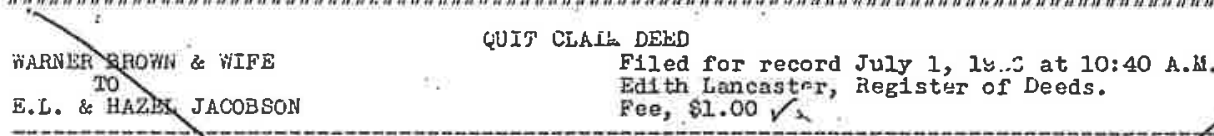
GUIT CLAIL DEED KHOW ALL Min BY THASE PFESENT: That I, harner Brom, of bickae, in the State of hlontana, 1n consideration of one pollar (\$1.00) to me poid by E.L.Jacobson and Hazel facobson, of Hardin, In the state of Montana, the recelpt whereor is hereby acknowleaged, do klereby remise, release, and forever quit dalm, unto the gaid E.L.Jacobson and Hazel Jacobsg/, all that parcel of land situate in the Cointy of York, Sbate of Nebraska, and bounded as follows, to-w1t: North $\frac{1}{5}$ west quarter (NWas) of Section Trenty two (Ne2), Tomsipip Ten/10: North, Fange Two (P) West of S1xth (6th) Princ1pal hieriainn, York County, Nekraska.

TO HAVE AND TO HOID the granted premises, with all prifileges and eppurtenances thereto belonging, to the satd E,L.Jacobson : and Hazel acobsch and thelr hefrs and assigns, to their own use and benoof gorever.

And 1 do hereby, for myseif and my helrs, executors and adailystrators, covenant with the sald grantee, and his helrs and agslgns, that the granted premises pre free from all 1 incumbrances made or suffered by ae, and that I will; and mig heirs, executons, and adminlstrators, shall, warrant and defend tho same to the sold grantee and his hetrs and algigns, forever agalnst the lawful clalms and elemands of all persons clalming by through or under mo.

And for the conglderation aroresald, I llella Brokn, of lickae, idcnt na, whe gf the said Harner Brom, go hereby release unto the sald grantee and his heirs and aisigns, alf rights of or to byon dower and homestea in the grented premises.

IN WITNESS WHEREOF, We have subscribed our names this 23 rd day or June, 1936. 
IRST: That John C. Balstor, deperted tinfa 11fe on the 7th day of Aovember, 1932, in Polk County,

ebraska, Intestate and at the time of his death he 7 as a resldent of Polk County, Nebraska.

BCoND: That on the 18th day of November, 1932 Robert H. Helster flled in this court a pet1t1on

reying for the appolntment of kathargn Shaneyfold es adminlstratrix of the estate of sald

seeased; and on the lath day of Novemier, 2932 an order of this Court zas mede therein assign:

IB the loth day of December, 2932 at jo o'clock h. H., at the County Court Room in sald Countj"

the time and plece for jearing said petition, and ordering.that notice be given to all per-

ing Interested in sald motter by publishing a notice of gala ordor in the Headlifht, a legal

okly nemspaper, printed and published in 5 ald county three sucressive reeks prior to a ofd day

hearjuB and it appears by proor on rile thet notice of seld order 7 as fiven es ordered by

is Courst.

IRD: The court further rinde that Kathryn Sheneyfalt named in sald petition was, unon her

$\sqrt{1}$ ing bond in the sum of $\$ 1000,00$ as ordered by this court, eppointed edministratrix es pray-

- the court further flnds that the deceesed at the time of his death wes a vidorer and thet left the lullowing helrs at $187:$

yne balster, Cfara Kalster end Loulsa HElster, daughters of the deceqged.

MTH: Thet on the 19th Lez of December, 2932, an order of th13 Court ras mede Glloring credi is three months in $\pi$ hlch to rile thgir clairs agafnst sald estate and the adrinlstratrix ore I In which to settlo salc estate from the 13th day of Janusry, 1933 and further ordering to notice of the suge be published in the Headlight lejel reekly nerspaper printed and liahed In sele Courity threc successive reeks prior to the 13th day or January, 2933, Bnd appoars by proof on I1le that not1ce of sald order tas published as ordered by th1s Court. PIF:H: The Colirt further finds that on the 19th day of January, 1932, the said Hatharyn jay:olt, Adminigtratrix filed in Eourt her inventory of the property of sald estate, end that 
according to seld Inventory the decessed died selzod und possessed of the following desoribed preperty, to-ilt: The South one helf (S S) of Iot three (3) of Block S1x (6) of Buckleg'o

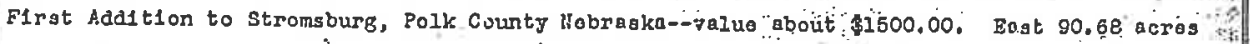
of southwest quarter of section thlrty (30) townshlp eloven (il) range two (2) York Count; Nebreska. And aloo the following describedreal estate in Malator Park Division $A^{n}$, a subdiviston of. p part of sit Sec. 30 Trp. 11, Range 2, Fork County; Nebraska; Lot Three (3) Lot Pour (4); Lot Five (5), except the Jorth 234 feet of the East 20 foet of a ald Lot; Lot 25 ; six (6) except the esst 20 feet; Lot Soven (7) except the East 86 feet; Loty Nino. (8) Ten (10), Elover (11), and Trelve (12); Lot Th1rtien (13) except a tianguler tract containinis about one-seventh of an acre in the southrest corner of sald lot thirteen (13), used for pliblif road, Lot Fourtoen (14)...-value ebout $\$ 11,000,00$.

Persenal property of approximately the value of $500: 00$,

SIXIII: The court further flncs that according to the lons of descent and distribution gald : property descenda as follows, to-rit: .

One thlrd Interast eoch to Maurine Malstir, Clara Malster, and Loulsa Malster.

The court further finds that the real astate knom and described as the southe of Lot 8 and 3. of Elock of of Euckley's First hadition to Stromsburg, Polk County liobraska, was the homesto of the deceased and of less value than $\$ 2000.00$ and as such $1 \mathrm{~s}$ exempt from the payment of debts ir. seld estate and is therofore set off to the heirs as herein named, freo and clear of encurbrance.

SEVENTI: The Court further rinds that on the 14th day of Apr11, 1933, an order of this Court was made barring all clasis not flled against said astate; that the costs of adrinlstretion In seld ostate havs boen paid and that there remaing no noney in tha hands of the oald adminis tratrix, anc thet said extate is insolvent.

EIOFrH: The court rurther finds that after deducting from the assets of sald astete, all debts, cleins, costs of acimistration, other-proper: expenditures and the statutory exemptions allowed the helrs at law in sald estate that there is due and payable to the Counts Treasurer of Polk Counts, Nobragka or to the County Trosurer of York Counts Nebraska, no inheritance tax.

It $1 \mathrm{~s}$ therefore orojed, adjudged and deareed by the court that the final report of the cdminlstratrix in sald estate be and the same is hereby approved and allowed as such; further that Kaurfine Malster, Giala kalster and Lowsa Malster, chllaren of decessed are all and the onity helrs at Ien of seld deceased, and that the property described in peragreph FIFTH hereof desconds accoring to the lans of descent and distribution of the state of Mobraska as found In paraereph SIXTK of this deoree; that an order of dischebge be issued to the gald Katharyn Shaneyfelt, adinistratrix out of and urder seal of this cuurt.

In vitness whereor, I heve hereunto sct $m_{j}$ hand and the seal or thecounty Court at 0 scoole, liebruska, this 22nd daj of Jenuarg, 1937.

(SEAL)

state of liebraska Counts of Polk

SS II THE COUNTY COURT OF POLK COUNTY NESRASKA,

I, L. He Herrick County wuige of PoIk County, Nebraska, do hereby certiry that I heve compared the foregoing copy of "Decreo of final settlement in the matter of the esteto of John $C$. Malgter, deconsed, with the original record thereor, now remaining in sald Court; that the same 1a a correct transcript thereof, and of the wholo of sald original record; and that I f hava the legal custody and control of sald orlginal record; thet sald court is a court of record, has e seal, and that sald Sal is hereto arflred; that said Court has a Clerk author ad to certify records in tho name of the County Judge of sold court; and that the forezolng attestation 13 in due form, eccording to the lars of the strte of Nebraska. 


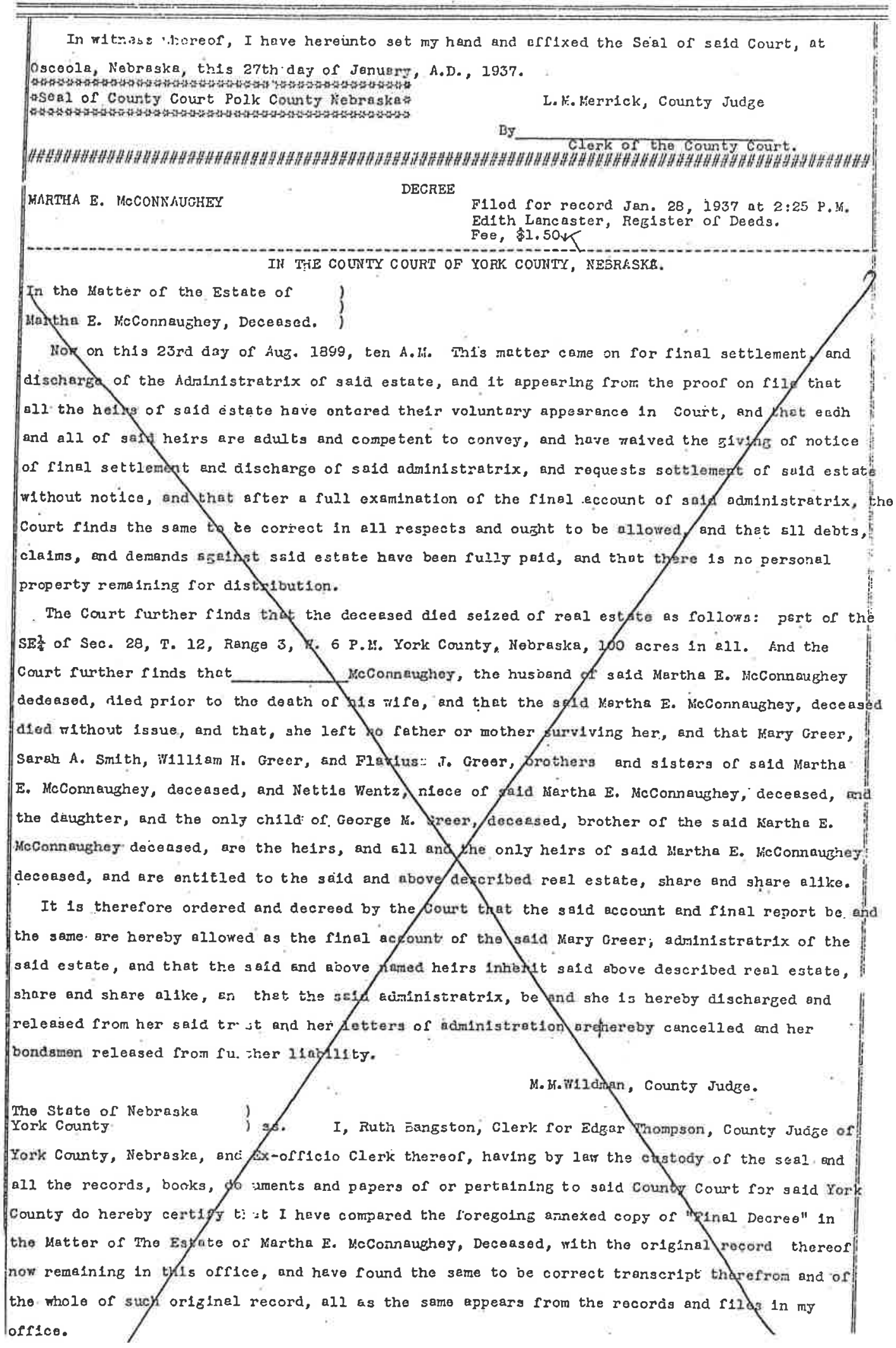




\section{DEED RECORD}

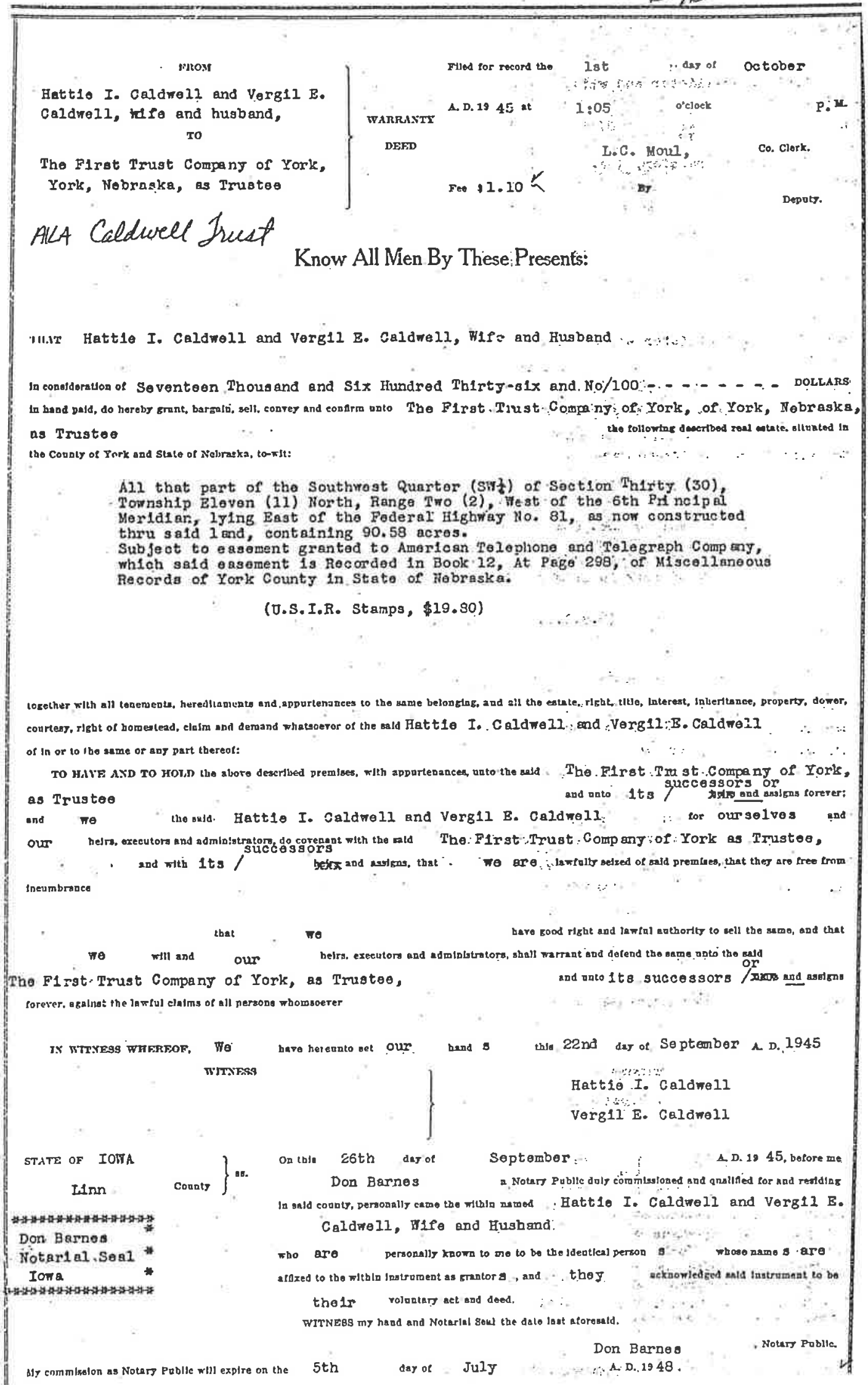




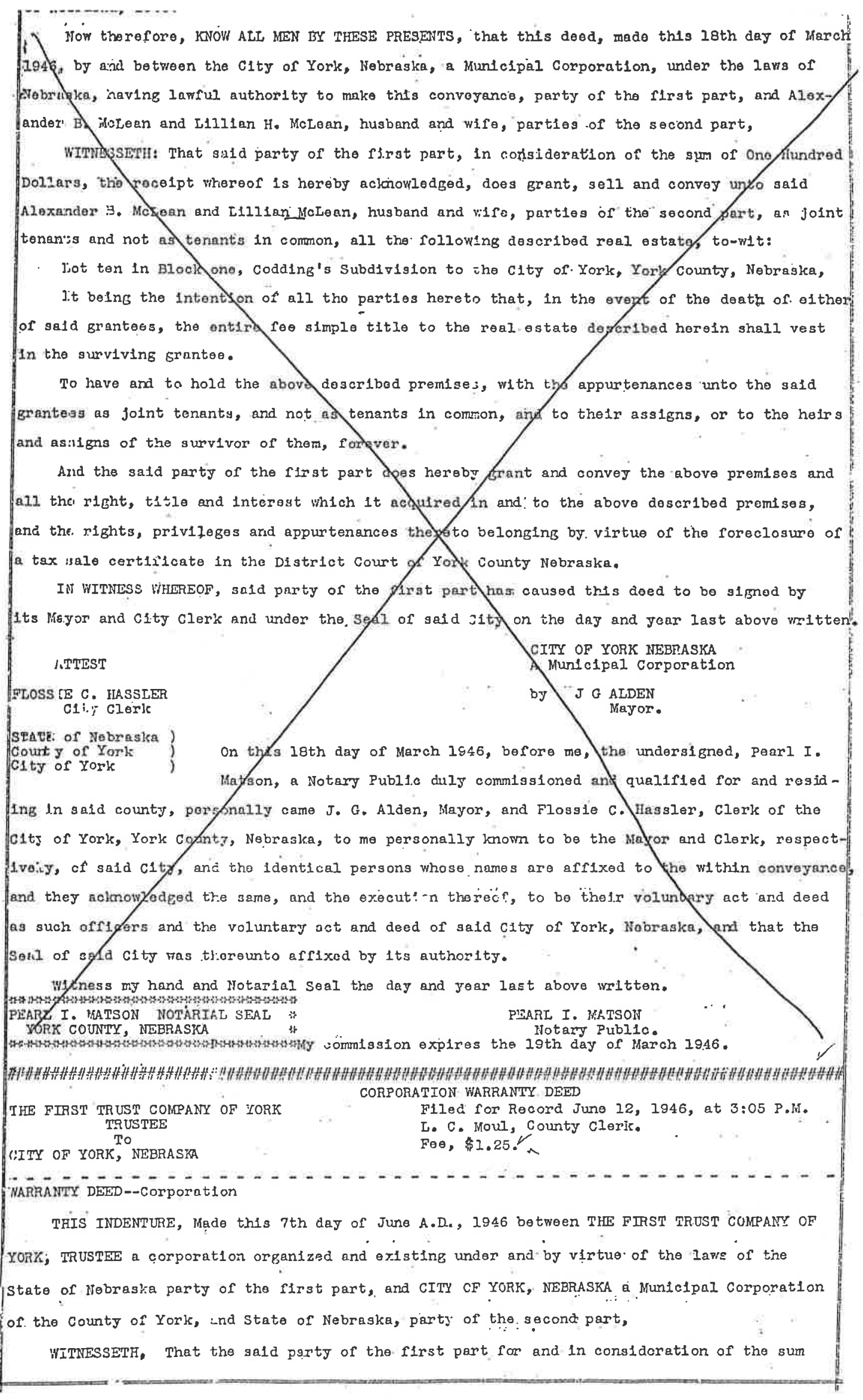




\section{DEED. RECORD?}

for Twenty S1X Thousand Flve Hundrod $S 1 x$ and 73/100 - - - DOLIARS 1 n hand pald, rooelpt whereor 1s hereby acknowledged, has sold and sy the se presentsidoes grant conver and con then unto the sald party of the second part, the following described promises as pounty, and State of Nebraska, to-mit:

AlI that part of the South Half of the Northwest Quarter (s a swin) of Section Thirty (30), Townshlp Eleven (11) North, Range Two (2) West of nthe 6 th Prinolpal. ... . Merldian, Iyling East of H1ghways No. Two and Thility-four as now constructed, (except that part herotofore conveyed to Russell. B. Learned and Pearl M. Learred, moro particularly described as follows: Commenolrig at a polnt where the East

ine of H1Ehway 2 and 34 intersects the north 1 ine of the south Half of the

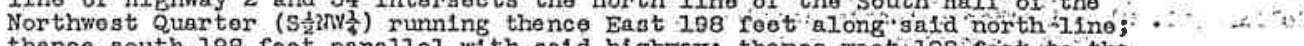
thence south 198 feet parallel. with sald highray; thence west 198 foet to the

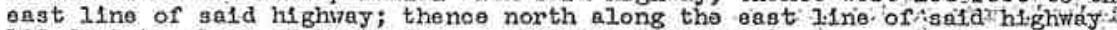
198 feet to place of beginning, containing 0.9 acres)

and all that part of the Southwest, Quarter (3W/ ) of Section Thirty (30), Tomnship Elevon (11) North, Range Two (2) Hest of the 6 th Princlpals Meridian iring East of Foderal Fighway No. 8I, as now constructed thru sald land, containing 90.58 acres.

$$
\text { 出 }
$$

Subject to Eesements grented Amorican Telophone and Telegraph Company recorded In Book 12 at page 298 and Book 12 at Page 279 of the ikiscellanoous hecords of York County and State of Nebraska. ats

TO HAVE AND TO HOLD Ehe promlses above described; together withiall the renementa, Hereditaments and Appurtenances thereunto belonglng unto the sald CITY OF YORK NERRASKS

And the sald THE FIRST TRUST COMPANY CF YORK, TRUSTEE fOr 1tseif or 1ts súccessors, does hereby corenant and agree to and with the sald part_of the second part and heirs and assigns, that at the thme of the execution and delfvers of these presents it is lawfuriy selaed of sald

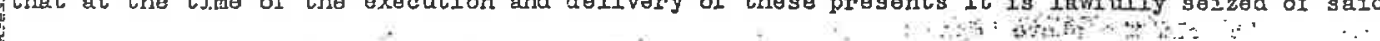
premises; that 1t has good right and lawrul authority to convey the same; that they are free from oncumbrance does horeby covenant to warrant and derend the sald promises agalnst the lanful claims or all. persans vihomsoever.

IN FITNESS WHEREOF, the saId THE FIRST TRUST COMPANY OF YORK, TRUSTEE has hereunto caused its oorporate soal to be afflxed and these prssents to be signed by its president the day ard yeer first above writteri.

Slgned, sealed and delfvered in

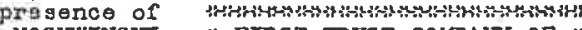
MAHY MOSKWINSKI * FIRST TRUST COMPAWY OF *

$$
\begin{array}{cccc} 
& \text { Y YORK } \\
& * & \text { YORK, NEBRASKA, } & \text { CORPORATE SEAL }
\end{array}
$$
A

STIATE OF NEBRASKA

rORK county s.3. Public in and for sald County, personaly came George H. Holdeman, Presldent of th's The Flrst Trust Company of York, Trustee to me personelly known to be the iPresident ani tho identical person whoso nume is affixei to the above conveyance; and. acknowledged the execution thereor to be his voluntary act and deed as such of ilcer: and the voluntary ect and deed of the sald The First Trust Company of $Y_{\text {ork, }}$, Trusteo, and that the Corporate seal of the sald The First Trust Compeny of York, Truster was thereto affixed by its authorlty.

Witness my hand and Notarial Seal at York in sald county the day and yoar last above written. Wy Commlssion axplres the 15 day of Februery 1950

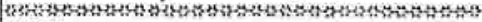
MARY MOSKWINSKI NOTARIAI SEAL *

YORK COUNTY, NEBRASKA

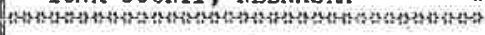

MARY MOSKWINSK 


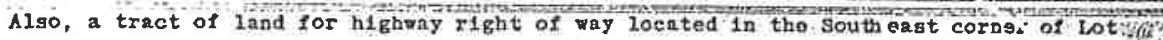
3 of Malster Park Addition to the c1ty of York in the southweit Quarter of soction 30, Township 11 Forth, Range 2 West of the 6th P.M., York County, Nebrask, degeribed,as 10110w日:

Beginning at the southeast corner of sald Lot 3 ; thence wegteriy on the South l1ne of sald lot 2 a distance of 134.3 leet; thence northessterly on a 1 ; 472.4 loot radius curve to the Left a distance of 86.7 feet to a polat 75.0 feet northerly from, meagured at right anglap to, ${ }^{-1}$ ald South 11ne; thence easterly on a line 75.0 feet northerly fromand parallel to sald south line 2.5 digtance of 92.4 feet to a point on the East line of sald Lot 3 i tbence southerly on gald Eagt 2 find 2 distance of 75.0 feet to the point of beginning, contalning 0.20 acre, more or lesa.

Ingress and egress Irom state Highray No, 2 and U. S. Bighray No. 82 onto land orrieci by the condemnee In part of Lot 2, Lots 3, 4, 5, 6, 2nd 7, Kalster Park Addition to the clty of York In the Southwest Quarter of Section 30, Township 11 North, Range 2 rest of the 6th P.K., York . County, Nebraska, Is 1 Imited to two commercial entrances not to exceed 10 feet in width to provide ingress and egress to property of the condemnee so long as they are used consistent w1th operating normal business activities as they exist, the center I1nes of vihich to be located 117.7 leet southerly from the North 11 ne of sald Lat 5 , and 125.4 feet southerly from the Nortb line of gaid' Lot 4 , respectively.

Now, therefore, we, as Appralsers aforesald, do bereby find: and eppraige the demases that w11l be suffered by reason, of the taking of easement to sald lands for right of viay purposel by the Department of Roads of the State of Nebraska, and also damages due to 11mitation of 1agress and egress. to sald Highrays, in amounts of:

We allow the followlng damages to:

BattioI. Caldwell and Virgil I. Caldwell, wife and husband; Reid Pentico, tenant (Caldwell property)

All of which 15 hereby respectfully submitted.

Dated this 9 day of March A.D., 1958.

L. Dale Hennia
$\frac{\text { Blfer Van Hogtrand }}{\text { Clinton F. Kitpatrick. }}$
Appralserg

THE STATE OF NEBRASEA, ) I, Hermann Glock County Judge of York County Nebragka, having by

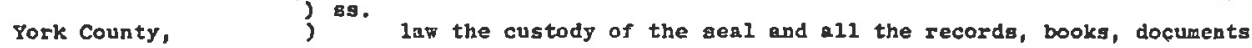
and papers of or pertalning to sald County Court for aud Yorifounty do hereby certify that I have compared the foregolng anpexed copy of RSTURY OF APPRAISERS in a condemation matter ent1tledi THE STATE OF NEBRASKa DEPARTIENT OF ROADS vs Hattle I. Cridwell and Virg1l I. Celdwell, wife and husband; Reld Pentico, tenant (Caldwell property); w1th the or 181 arl record thereof now reaning in this office, and have lound the same to be correct trangeript there from and of the , whole of such original record, all as the same appears from the records and flles in my office.

IN TESTIXONY nHEREOF, N1tnegs my hand and the senl of the County court of York County, Mebraska, thls loth day of Apr11, A.D., 1958.

. County court ö York -County Netraska-Seal ..........................

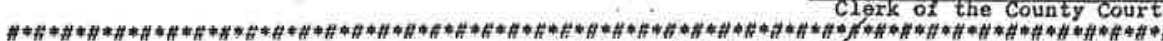
Re: Leura $X$. Huber, et 21 .

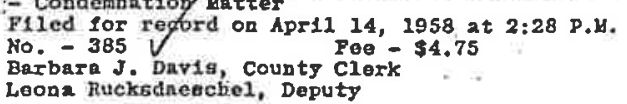


THIS INOBNTURE, Mado this 170 day of September R.D., 1965 botvoen the Clty of York a Munlelpal Corporat lon organl zod and oxisting under and by Firtue of the levs of the Stete of Nobraska, party of the flrat part, and The State of Mobrasks, perty of the socond part,

गITNESSET:, That the oald party of the (Lrst part for and In conslderation of the ore of - . . One end $\infty / 100 \ldots-(\$ 1.00) \ldots$ - . NLLAPS In hand pald, recelpt whoreof Lo heroby ackmowlodger, has sold and by theso prosents does grant, conres and couflem onto...

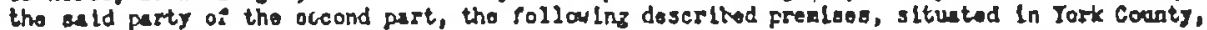
and state of Hotraske, to-ult:

A atrip of land for hlehway rlghw of way Iylne aceoss thio iouthwast Qurter of Sectlon 30, Tounst:Ip 11 Korth, Dance 2 Wost u: the Sth F.Y., Tark County, Hohrsata, deocrttad as eollow:

Referrine to the southuest corner of sald sertion 30; thence easterly on the South 11 so of the Pouthuest Quartor of sald sectlon 32 a distence of $1,278.9$ Sont; thence northerly 99 degroes 10 minutes loft a distance of 33.0 foot to the polnt of reglnnlnz; thenco continulnz nartherly on the last descritad coarse produced and on the eastern rlght of way line of the present (Kay, 125B) hlghway a distance of $2,590.1$ PaOt to a folnt. on the Horth lin of gald southust Quartor, sald polnt iving locatod $1 ; 277.0$ fost eastorly fron tho nurthwest cormer of seld Southuest Quartor; thance osstorly on sald Horth line a distance of 62.9 Soot; thence southerly a dlstence of 2, $\{70.7$ feot. to a polnt 33.0 sect nartharly fror sald South Ilns; thence westerly on I Ino 33.0 foot northerly Crom and farallal o sald Couth line a distance o: 7.9 leot to the polnt of toglnning, contalning 4.12 acres, moro or less.

Also a strif of land "ur hlghway rlght of way loseted in the outh half of the Northuest Quarter of ieclion 30, Townshlp 11 Horth, Range 2 diest of the "th P.K., Tork County, Mohraska, dosiorlted as Collows:

Recorilng to the wost nuptor cornur of suld Sectlon 30; thance asstorly

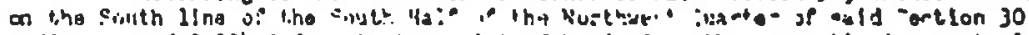

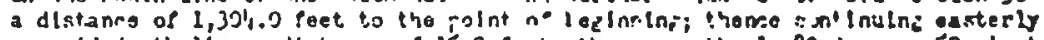

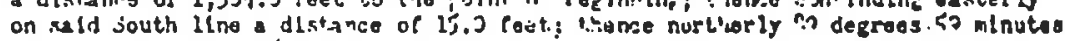
left and on a 11 ne 27.0 peat easterly fram and parallel to the esetern right of usy line of prosent (125R) hLehray, a distunce of $1,130.3$ soot to a polnt 190.0 foot enutherly from the llorth liro of sild "outh Hall of the Horthuest Quarter: thence wijterly 90 degroes $12 \pi$ Inut.es loft and on a lino 129.0 leet southarly tran axd perallol to sald North IIne a distunce. of 15.0 foet to a polnt on the esern 60 toot rlght of vay ilno of prosent (May, 1959) hLehvay; thonce southordy 19 do grees L8 minutes loft ans on sald 60.0 loot hlehway rlght of vay Ilna a dirtence of

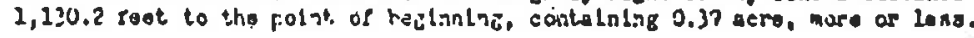

The rit.y lecoby rennores thw unrostrleted rlight of pllght :hrough the - Ir spare oror and across tho abova donncitod trast of land and also reacrus

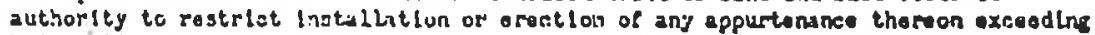

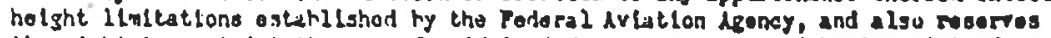

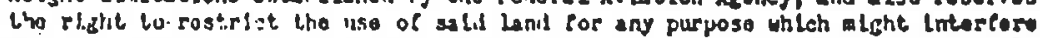
with noral ilrport operational astlolltas.

In the evart bho land afjanont to tho atore tosarlted trast ceasen to the usol or oparalod as an alr, rort the arove righte, -jonervations and restrintclong sta.li io aut.oratially nuli anl zold.

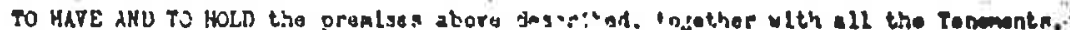

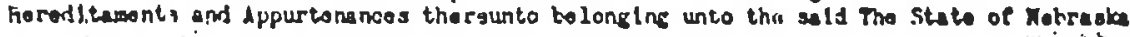

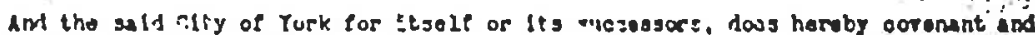

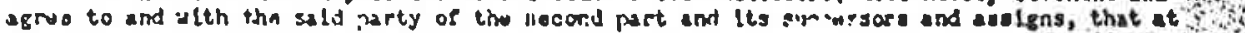

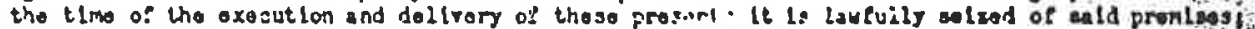

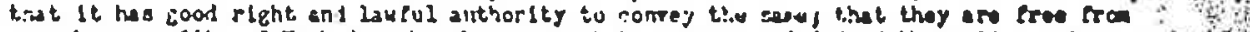

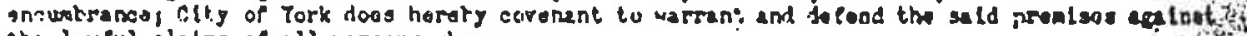
the Luful ilalas of all porsons utiomsoever.
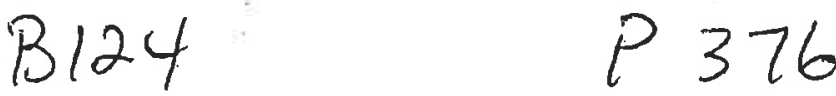


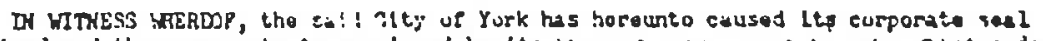

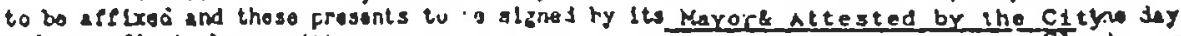
and year llest sbore vrilten.
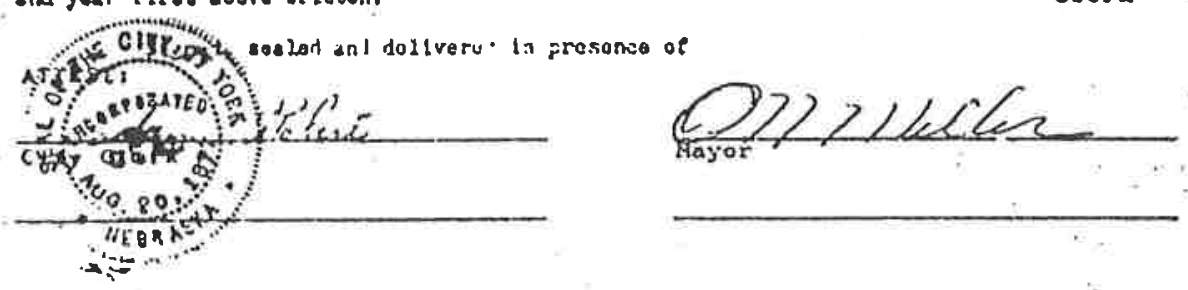

$\therefore=\ldots$

JTATE OP MFARUSKhj

YORK County'

$$
\therefore
$$

Un thls 170 day of September, 1265 tefora ke, tha undursignod, a Notary Puhlle in am lor sald Tounty, porsonally camo O. N. Miller, Mayur." Etwin Roberts, Cjty Clerk of tho Clty of York to no par sonally known to to tho Playor o CityClerdnd the Identical porson whose naro is affixed to the atove conveyanco, and acknowledged the exesutton theseof to to hls voluntary uct and hood

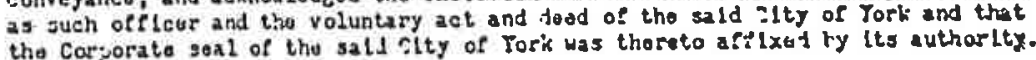

Hitness my hand and Yot.zrtal foal at York In sald County the day and year last arovo uritton.

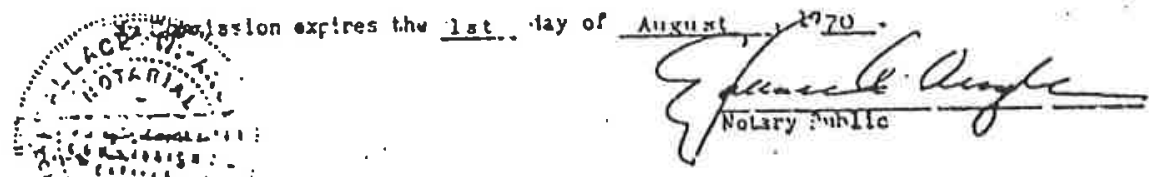

B124 
CORPORATION QUITCLAIM DEED

The Rrantor YORK COLD STORAGE COHPANY,

n corporation opganired and exikting nnder and by virtlle of the Inus of the State of Hebraska

in eonsilteration of One Dollar (1.00)

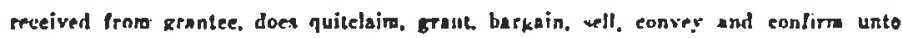

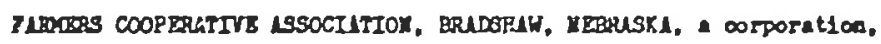
herein ealled the grantes whether one or wore, the following dexpribed real property io York Connty. Nobraxka:

Al1 that part of the East 240 feet of Lot Two (2), Iylng north and vest of U. S. H1stwer Ho. 34, In Malster Park, DIviaion A, belng a part of the Southwege Quarter (Six $)$ of Sectlon 30. Towshtp Rleven (1I) Mortb, Range. Two (2), West of tbe 6ch P.M., in Yort County, Nebraka, wore particularly described as follows:

Comencling at polat on tbe bortb line of suld lot 2 whlch 15240 feet wat of the portheas eoran thereol. runains thence south 16.7 feet. ruming thence portberaterly

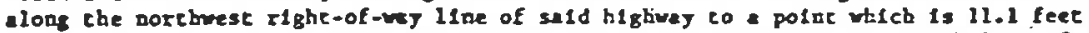
ease of the polnt of beg.aning and running thence due vest along the north line of cald Lot 2 euch diatance of 11.1 feet to sold point of beginning.
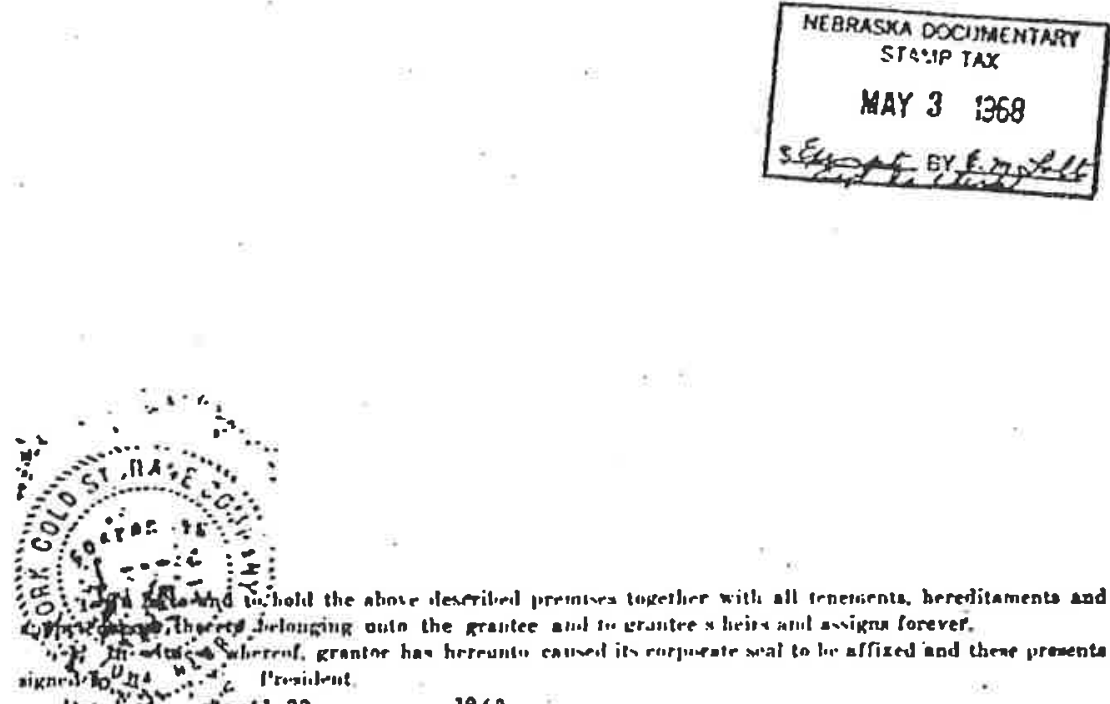

lnteit 1968.

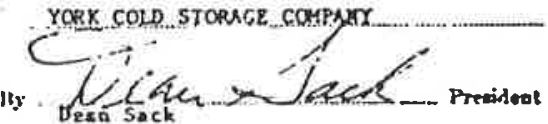

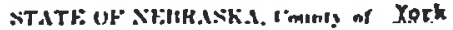

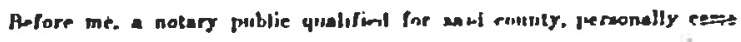

Jeen Ieck,

Preaidast of

York Cold Storage Company ... Eerportiog,

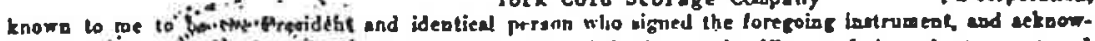

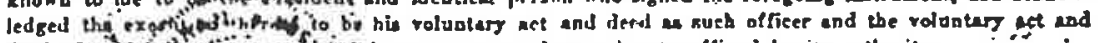

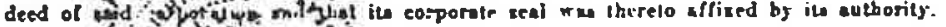

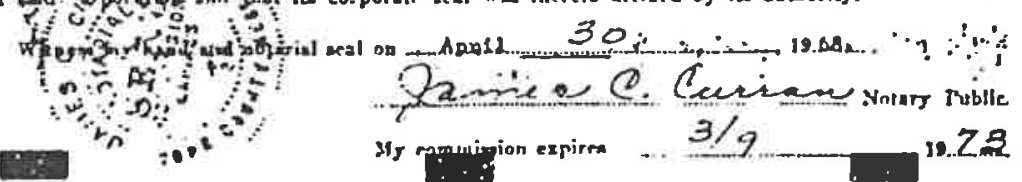




\section{KNOW ALL MEN BY THESE PRESENTS:}

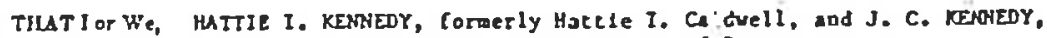
1f. ond husband of the Councy of Linn, State of Ims,

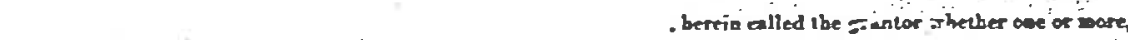

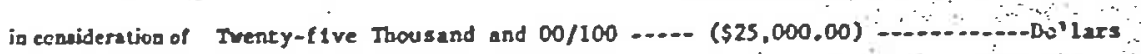

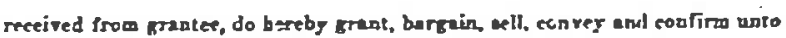

$$
\text { REW'S SERV:CE, IHC. }
$$

bercin ealled the grantee whether one of mure, the following deseribud real property in

Yorit

Cunaty, Mebraska

The eant 240 fect of Lots Three (3) and Four (4) and the ease 240

foet of the wouth 244 feet of Lot Flve (3) III Kalster Park. Division A,

besng. part of the Souchueat quarter (SH) of Section Thirty (30),

Tomihlp Eleven (11) North., Range tvo (2), Veat of the 6ch P.M., in

York County. Hebraskn, subject to esaements and jolne drivevay agree-

Eent of record, and subject to linitations on access set forth in the

retura of appralsers in exinent doaaln proceedings vhich return 13.

return of apraisers in elai 24 of the Hiscellaneous Real. Estate Records

recorded at book 15. page $24 i$ of the Hiscellareous Real. Estate Records

thereof beretofore comveyed to rhe State of Nebrasks by deeds of record

or an rlgtt, title and incerest in sald real estike icquit ad by virtue

of the aforejald eninent domin proceediags.

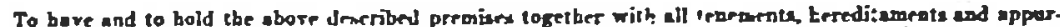

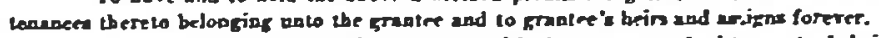

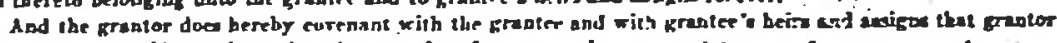
in lawfully meimed of aid premise: that thry are fref frum rneumbrance subject only eo exeept fors

- bove noted;

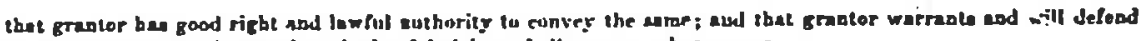

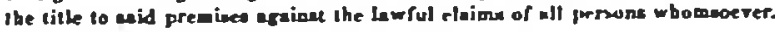

Detel 17th day of Aprit is 68.

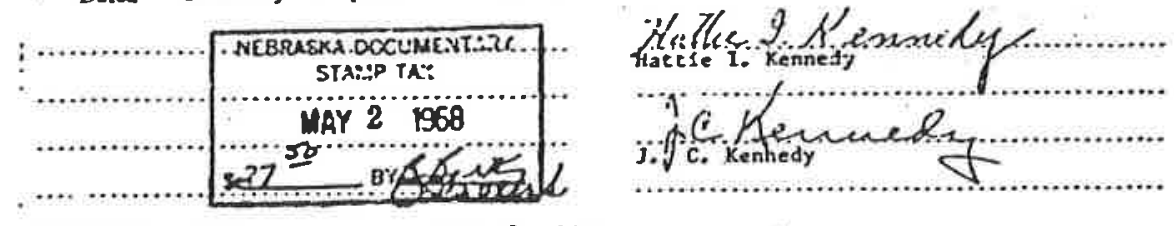

, BTATE OF.... IOA .............., County of.....Lian ................

Betore me, a octary publie qualified for wid eounty, pereonally eamor

Mactie I. Kennedy and J. C. Kennedy, wile and husband,

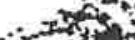

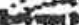

7 -

(1)

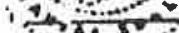

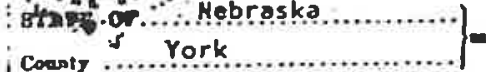

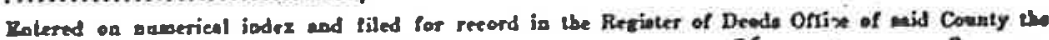

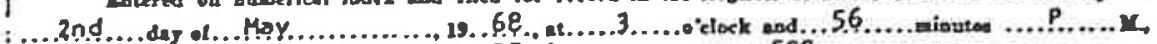

and roeorded in Book. 128

Fee 1.75

$i$ i-unaer's or...Eeds

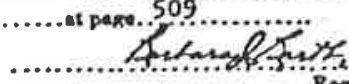

Bs .................................... Depenty

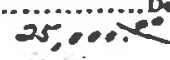


ORDIrusces 10. 1074

An ordinence diracting the ale and convayence ol carteln real etcete In Yock

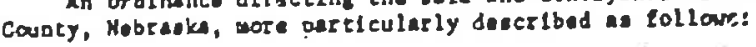

A trip of lend for highray tlght of way lylag eercas the souchuat quittar

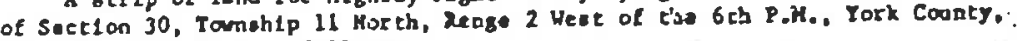
liabrakk, deseribed as Lollare:

Toferring to the Sourthuest cornar of geld sectics 30 ; thence anterly on he south teat thenca Hortherly 90 degrees 10 sinutes left a diatance 0 of 33,0 feet to the porting northerly on the last described course producad and on the eastern rl, the of vay line of the present (Kay, 1938) highisy produced asd on tho of sald Southuat quartor, a diatance of $2,390.4$ laet to a point on the Nrth line or sald souther corner of easd sald point being located $1,377.0$ faet aaterly. froa the northwat corner or eald acuthest quartor; thonce easterly on aeld Horth 11 a a diatance of 62.0 foet; thonce

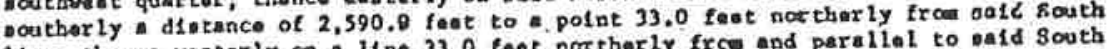
lins; thance waserly on a lina 33.0 teet northerly frce and perallat to oard south 11ns; distance of 87.0 faet to the polnt of boginning, containing 4.42 scrat, wore or lane.

1.0 a tip of land for highwey right of way locsed in the south belt the Kor theast quarter of Section 30. Tamshlp il Morth, Range 2 Waet of the 6th P.M., York County, Mabreake daertbed. a follare:

Reforring to the weat quarter corner of satd gection 3e; thence asearly on South line of the South half of the Forthuas Quarter of sald section 30 the South It of of the south hat the polnt of beginning; thence contiuing aseterly a distices lett and on. IIne 15.0 foet ansterly frca and parallel to the eascern $x$ gath of vay lott and on a line 15.0 highvay, s dietance of $1,130.3$ faet to a point 198.0 leat

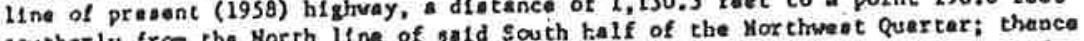
southarly from tho North line of sald south kalf of the Korthwest Quertar; thanco weterly 90 degrese 12 alnutas left and on a 11 na 198.0 foet acuthurly from and waterty psrallal to and North Iina a distance (May, 1958) highuay; thence southerly 89 60 foot right of way IIne of present (Hay, 1958) highway; thence southarly degrees 48 minutes left and on sald 60.0 foot highway $r$ ght of vay ins a wase or leas.

BE IT ORDAINED BY IHE MAYOR AK COUHCIL OF TIE CIT OP YORK, MTaUST, as rollats:

Sect10, 1. Pursuent to the provitions of Sec. 16-202, R.S., 1943, as anded,

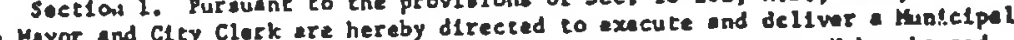
the Mayor and Cley Clark are hereby directed to axacuce and dell

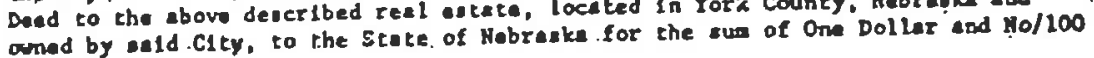
$(\$ 1.00)$

section 2. Norlce of uch sele and the terme thareol thell be published for (3) coneen (3) consecuctre water peine and pubilcection as required by lav.

pasad and appioved thlo 12 th day of
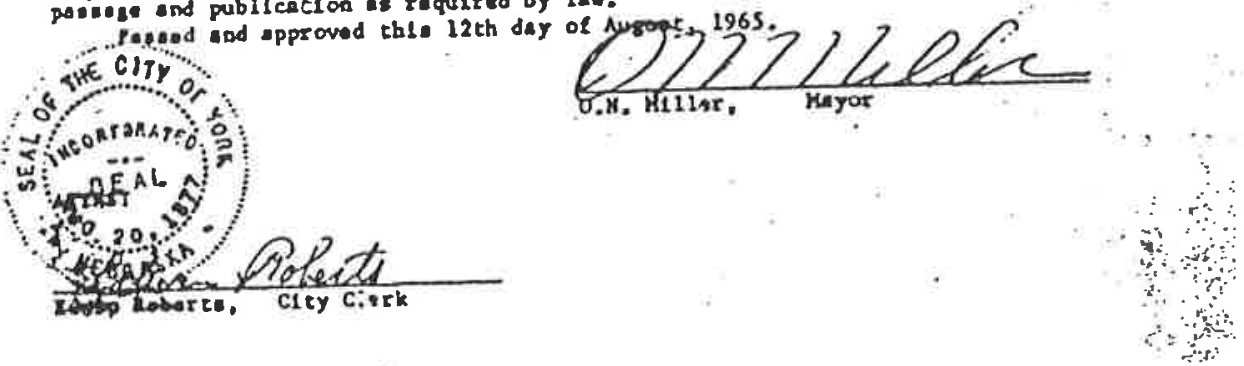


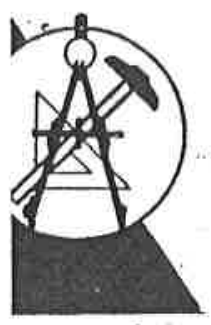

SURVEY RECORD

IOEL.

County, Nebraska

Darrel W. Simonds \& Associates, Inc. Surveying and Mapping

Thoot 2 of 2

6900 Loighton Avenve :- Lincoln, Nebraska 68507

IRRTOULAL TRAOT NO. 24

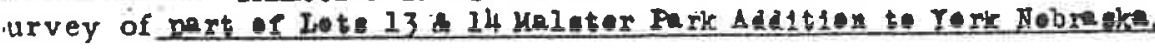

1n the sentluest Orertior of

Section 30 TIN, R2 of 6th P.M.

urvey No.

(To be assigned by Co. Surveyer) Date 26 surest971 Woather In 1 r

I RREGOTUI TRAC2 I0. 24

DRSORPIOA

A pert of Lot $13 \& 14$ of Nalster Fark Addition to the City of Iork 12 thesenthwent guarter of Section 30, Tewblo 11 Forth, Bange 2 Yost of the 6th P.H., Yerk County; Hebrink, wore fully deseribed belows

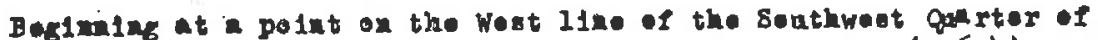
Seet ion 30 and one huedred twenty-81x and four tenth (126.4) Ioot

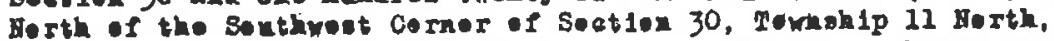

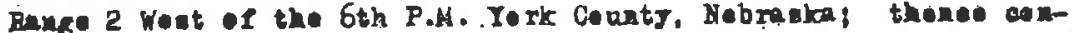
tinuing Iorthorly aleng the West line of the seuthvest quater of ald Section 30 , a distance of Three hudred sixty-three and Flghty coren hundrodthe $(363.87)$ foet; theree Right $90^{\circ} 00^{\prime}$ 00" in an

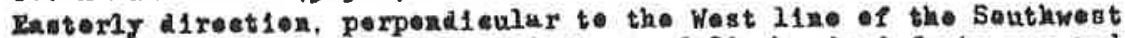
geratex of gald Sestion 30 , a distance of $S 1 x$ hundrod forty-one and forty+two hud redth $(641.42)$ feat; thenee right $90^{\circ} 03^{\prime} .00^{n}$ in a Southerly direction a distance of One huxdred thirty-81x and eight tonthe (136.8) reet to a polat on the Bortherly Right -of-way 11ne of U.S. Highray t 34; theneo R1ght $64^{\circ} 09^{\prime} 00^{\text {al }}$ in a Southwesterly direetion along tho Northerly Right-of-ney line of U.S. Highway 34 a distanee of Three huadred fifty-five and four tonths (355.4) foet; theree Right $12^{\circ} 32^{\prime} 00^{M}$ in a West Southwesterly drection aleng the Northerly R1ght-ef-vay 11.e of U.S. Highwiy *34, a diatinee of Twe huadrod ninety-81x and two tenths (296.2) foot to a point Thirtythree and we tenthe (33.0) foat Esst of the West 21 ine of the fouthwest Quarter of said Seotion 30; thence Ieft $00^{\circ} 32^{\prime} 00^{4}$ in a West Southwesterly diroctien along the Hortherly Raght-of-wiy line of U.S. H1ghway 34 , a distares of Thirty-three and eighty-throo hundrodth (33.83) foet to the point of boginalief and contrining a calculet a rea of 4,00 Acres, more or loss.

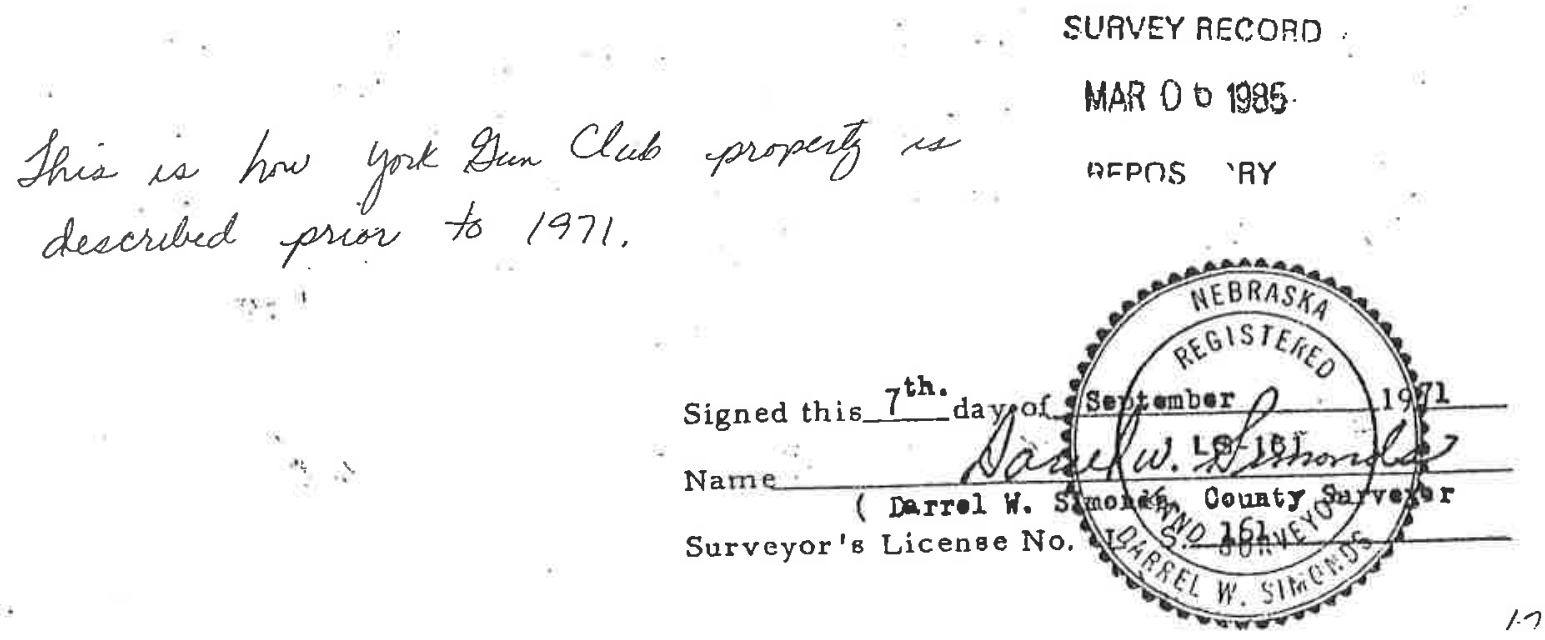




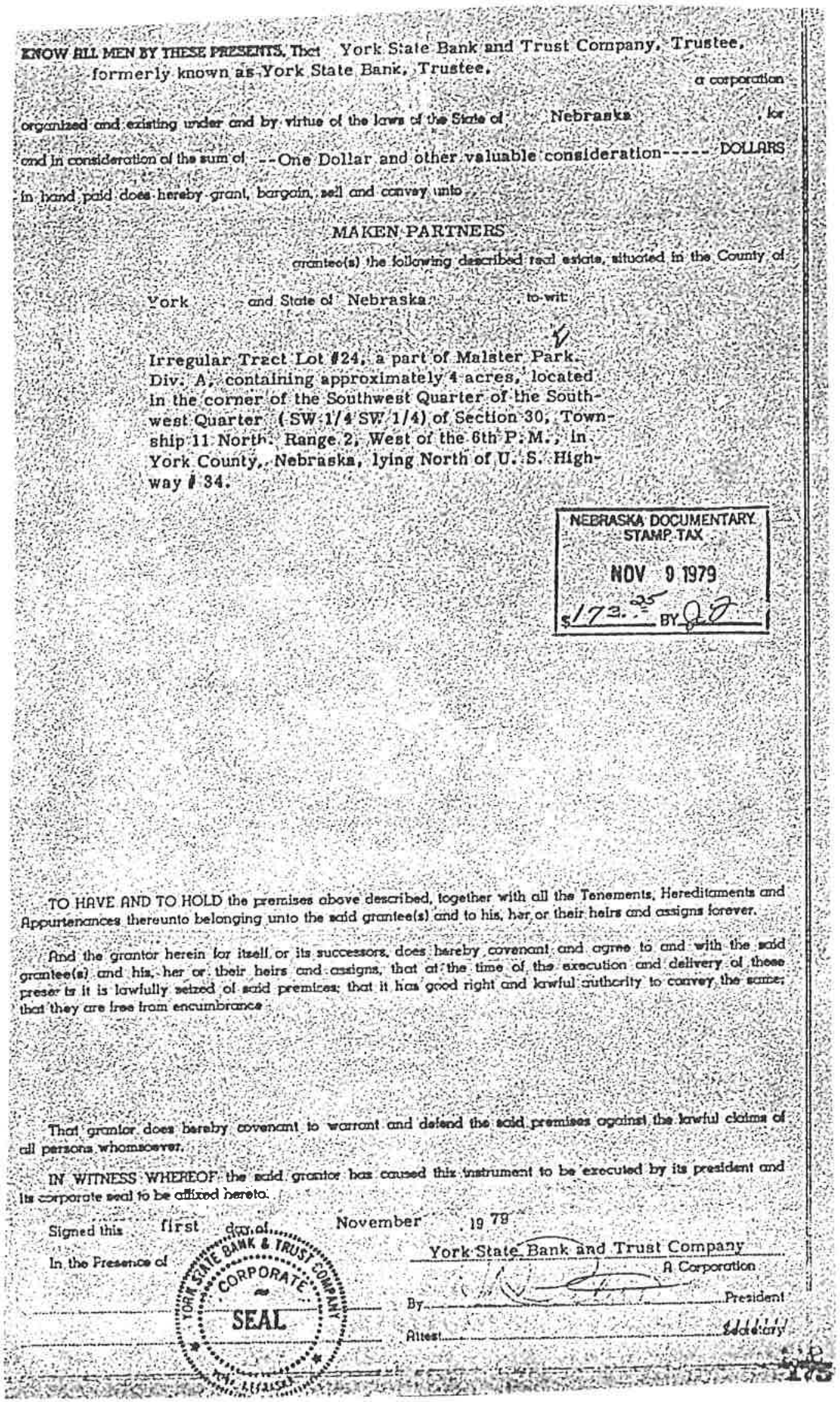




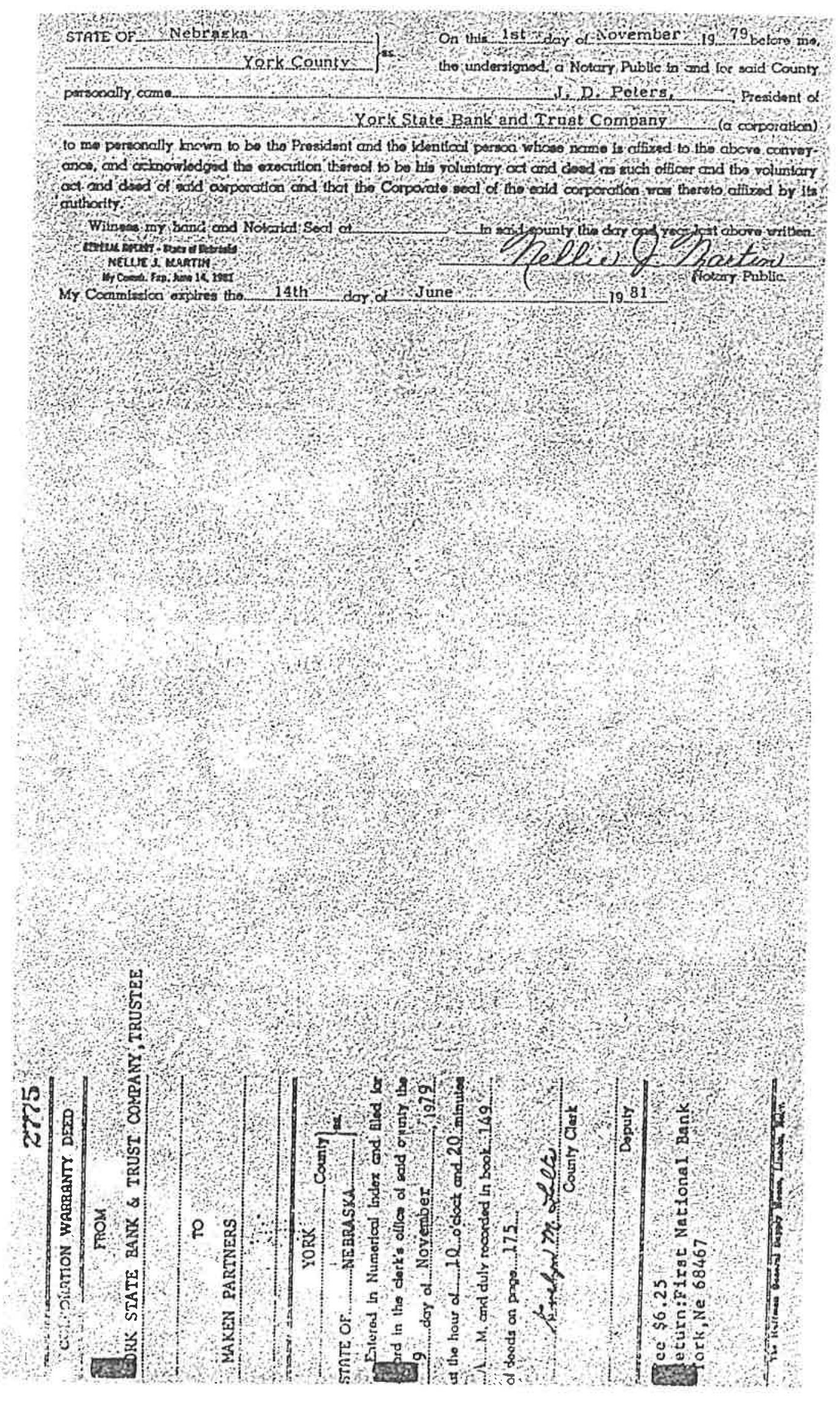




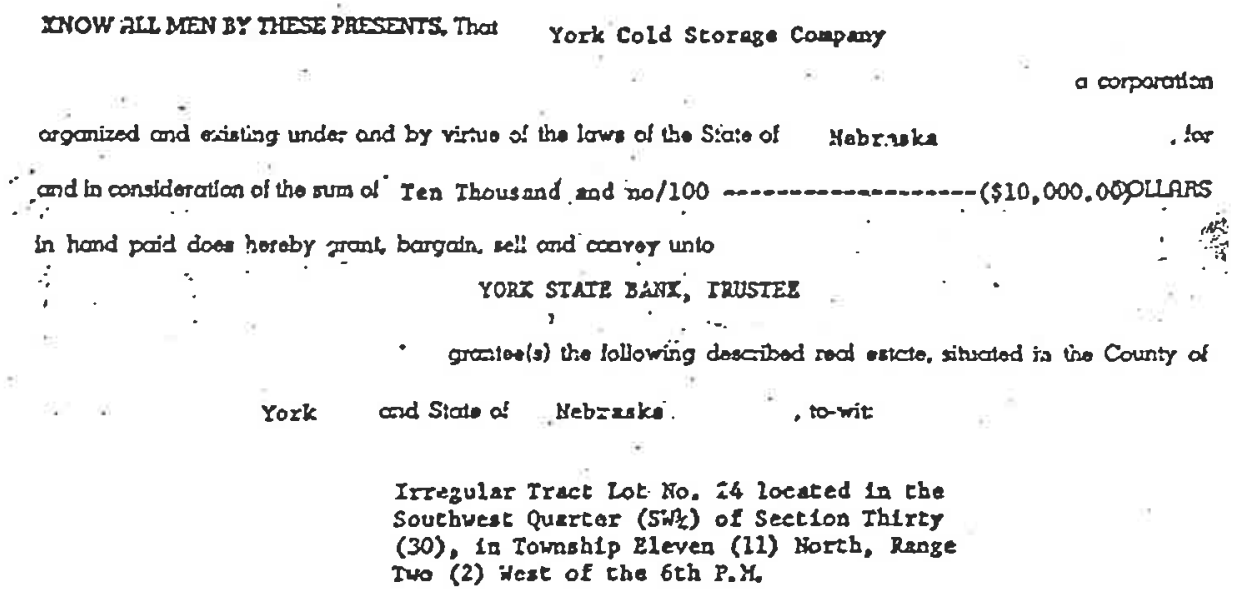

TO HAVE AND TO HOLD the premises axoro described, together with all the Tanements, Heacditaments cria Apputenances thesounto belonging unlo the scid gronteo(s) and to his, her at thetr haise cund ossigns forever.

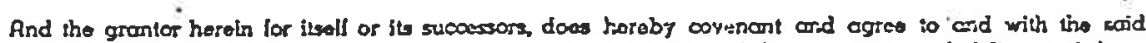

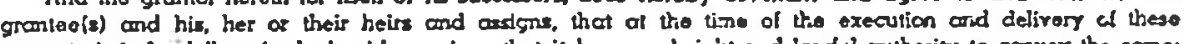

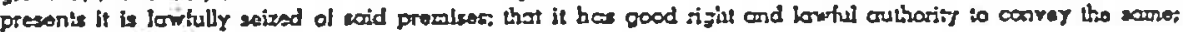
that they cro Irse fropt estcumiorarce
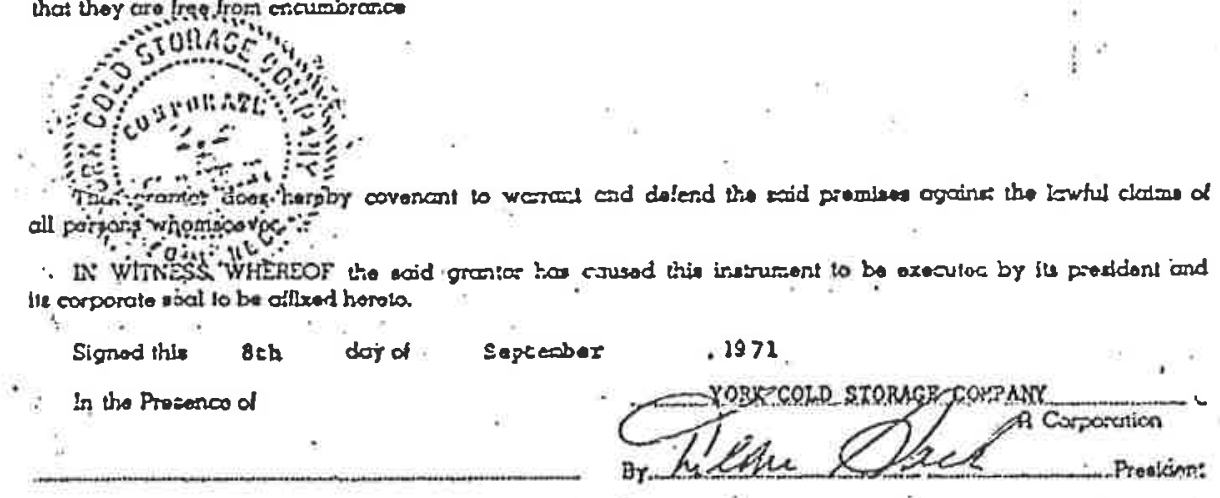

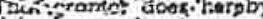

all porzon whompor 0 .

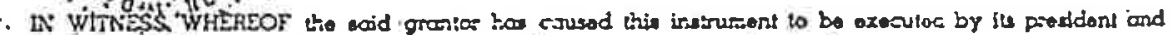
is corporate sical lo be aflued horota

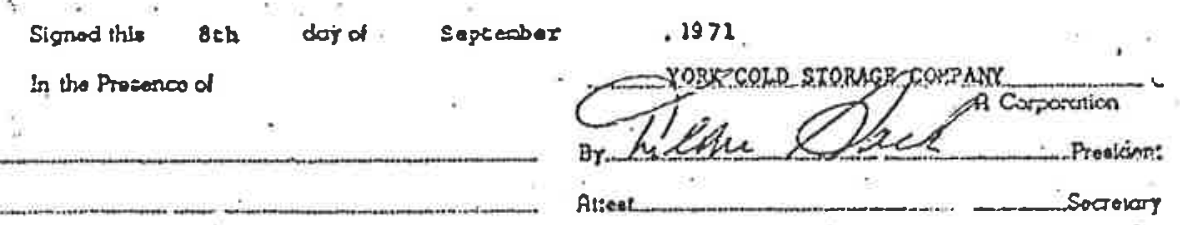




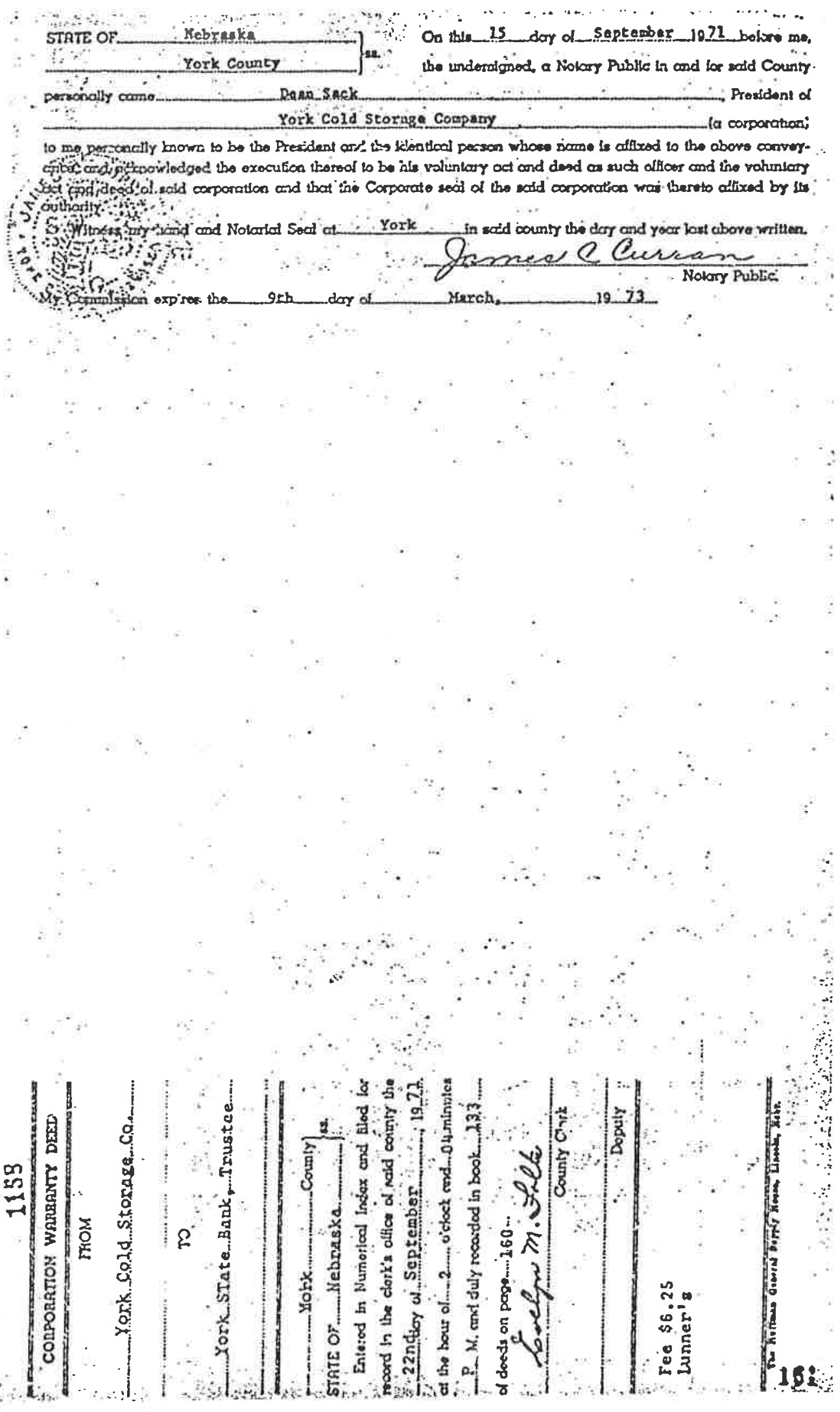




\section{DEED OF TRUST.}

THIS DEED OF TRUST is made this....... 21 tat.

21.t. ............. day of ....... Juls

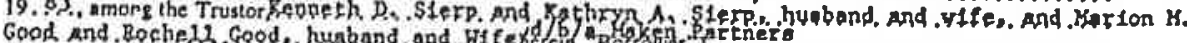

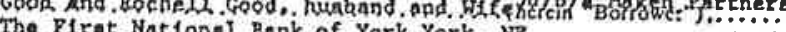

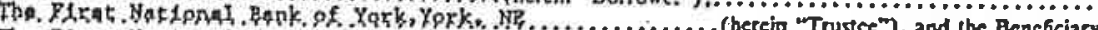

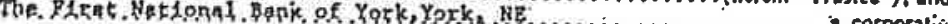
existing under the laws of P. 0.0 Bax 69, York.

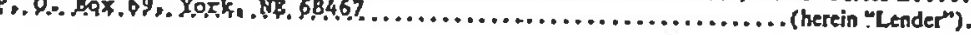

Borkowen, in consideration of the indebledness herein recited and the trust harein ereated, irrevoeably erents and conveys to Trustee, in trust, with porwer of sale, the following described property located in the County of ............... Yoxk. ..................., State of Nebraska:

A part of Lots Two (2), Three (3), and Feur (4) In talater Park, Diviolon

$A_{1}$ - part of the City of York, York County, Hebrisks, described as follows:

N11. that part of the Weat 331 feet of Lot Two (2) 1 ying Horth and : West of the Northrasterly right-of-way line of State Highvay No. . 34; all of the Nest 331 feet of Lot Three (3) EXCEPT the North 83 feet thereof; the Ralt 85 faet of the West 331 Yeet of the Horth 83 feet of Lot Three (3); and that part of. the Zast 85 feet of the Weat 331 feet of Lot Pour (4) lying South of the tract deaded to tha City of York for street purposes and know as a part of
Sundstrand Drive.

Irregular Traet Lot 124, a part of Yalater Park, Division $A_{p}$ contalning approximately 4 ecres, located in the comer of the Southwest quarter of the Southwest Quarter (STHF SH/ ) of Section 30, Tounship 11 North, Range 2, Hest of the -6th P.M. In Yorik County, Nebraska, lylag Nortk of 0. S. Highray 134 .

whish hes the iddress of .... (herein "Property Address") ICHyi

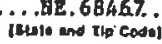

Toostues with all the imprevements now or hereafter erected on the property, und ull easements, rights. appurtenanees, rents (subjeet hewever to the rights and authorities given herein to Lender to colleet and apply such renty), royalties, mineral, oil and gas rights and proflis, water. water rights, and water stoek, and all fixtures now or hereafter attuched to the property, all of which, including replacements and additions thereto, shall be deemes to be and remain a part of the property ecovered by this Decd of Trust; and all of the foregoine. together with said property (or the lesschold estate If this Deed of Trust is on a leasehold) are hercin referred to as the "Property":

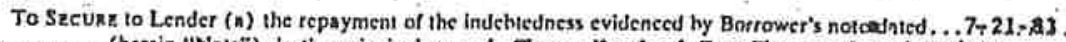
........... (herein "Note"), in the principal sum of. Threa. Hundrad. Ton. Thousend, and . $\$ 0 / 100$ -

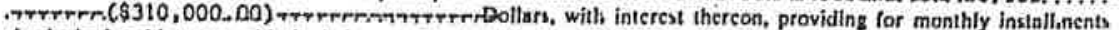
of princlpal and interest, with the balance of the Indebiedness, if not seoner paid, due and payable on Jenuary. $.17, .1984$ sand. . August $.15, .1921 \ldots \ldots \ldots \ldots$ the payment of all oiher sums, with interest thercon, advancel in aceordance herewith to protect the security of this Deed of Truat; and the performance of the covenunts and a greements of Borrower herein contained; and (b) the repayment of any future advanees, with interest thercon, made to Borrower by Lender pursuant to paragraph 21 herent (herein "Future Advances").

Borrower covenants that Borrower la lawfully sew-d of the estate herchy ennveyed and hax the right to granl and convey the Property, that the Properly is unencumrested, and that Borrower will warrant and dafend generally the tille to the Property ugainst all ela ims and demands, subject to any declarations, easemenis or restipetions llyed in sechedule of exeeptions 10 coverage in uny ttle insurance policy insuring Lenter's interest in the Property.

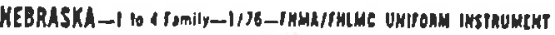

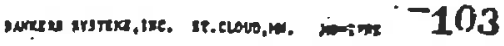


UNITORM COVENANTR. Bortower and l.ender covenant and agree as follows:

1. Payment of Principal and Interest. Borrower shall premplly pay when die the principat of and interest on the indebtedness evidenced by the Note, prepayment and late charges as provided in the Note, and the principal of ant interest on any Future Auvances secured by this beed of Trust.

to Lender on the day monthly installments of pubject to applientic law or to a written waiver by Lender, Bortower shall pay a sum (herein "Funcs") equal to one-twel(f principat and interest are payable uncter the Note, until the None is paid in fuli. Deed of Trust, and rround rents on the Preperty, if any, plus one-twelfth assecsments which may attain pribrity over this plus one-twelfith of yearly premitum installments for morigage Insurance, if any. all as reasonably estimated initially and from

time to time by Lender on the basis of assessments and hills and reasonabie estimates thereof.
The Funds shall be held in an inatitution the deposits of accounts of which are insured or guaraniced by a Federal or state ageney (including Lender if Lender is sueit an institution). Lender shall apply the Funds in pay said taxes, assessments. insurance premiums and ground rents, Lender may not charge for so holding and applying the Funds, analyzing said account or verilying and compiling said assessments and bills, unless. Lender pays Borrower interest on the Funds and applicable law permits Lender to make such a charge. Burrower and L.ender may agree in writing at the time of execution of this beed of Trust that interest on the Funds shall be paid to Borrower. and venless such agreement is made or applicable law requires such interest to be paid. Lender shall not be required to pay Borrower any interest or catnings on the Funda. Lender purpose for which exch debit to the Funds was made. The Funds are pledged as additional security for the sums secured by this Decd of Trust.

If the amount of the Funds held by Lender, together with the future monthly inuallments of Funds payale prior to the due dates of taxes, assessmenis, inaurance premiums and eround rents, shall excecd the amount required payabie prior to assessments, insurance premiums and ground rents as they foll due, such excess thill he, at Borrowers pay said taxcs, promptly repjid to Borrower or crediled to Borrower on monthly installments of Finds. It the amount of the Funde Borrower stall shall not be sumeient to pay taxes, assesements, incurance premiums and ground rents as they fall due. by Lender to Borrowet requesting amount neceusaty

Upon payment in full of all xums secuted by this Deed of Trust, l.ender shall promptly refund to Borrawer any Funds held by l.ender. If under paragraph 18 hereof the Property is sold or the Praperty is otherwise acquired by t.ender. Lendet
shall apply. no later than Immedlately prior to the sale of the Property or its aequisition by Lender, any Funds held by ender at the time of application as a credit against the sums secured by this Deed of Trust.

3. A pplikation of Payments. Unless applicable law provides otherwise, all payments received by Lender yrder the Note and paragraphs 1 and 2 hereor shall be applied by Lender first in payment of amounts payable to Lender by Borrower
under paragraph thereof. then to interest payable on the Not:. then to the principal of the Note, and then to irterst and principal on any Future Advances.

4. Charzes; Lens. Borrower shall pay all iaxes, assessmenis and other charges, fines and impositions at:ributable is the Property which may attain a priority over this Deed of Trust, and leasehold payments or ground rents, if any, in the manner provided under paragraph 2 hereof or, if not paid in such manner, by Borrower making payment. whe:a due. directiy to the payee thereof. Borrnwer shall promptly furnish to Lender all notices of amounts due under this paragraph, and in the event Borrower shall make payment direetly. Borrower shall promptiy furnish to Lender receipts evidencins, sueh payments. Borrowe; shall prompily discharge any lien which has priority over this Deed of Trust: provided, that Borfower shall not ixe required to discharge any such lien so long as Borrower shall agree in writing to the payment of the coligation secured by such lier, in a manner acceptable to Lender, or shall in good faith contest such lien by, or, defend enforcement of such lien in. e al proceedings which operate to prevent the enforeement of the lien or forfciture of the Propsiy or any part thereof. against loss by fire. hazards inc.luded within the term "extended coverage". and such other hazards is Lender may fequire agd in such amounts and for such periods as Lender may require: provided, that Lender shall not require that the amount of
and and in such amounts and for such periods as Lender may require: provided, that Lender shall net require
such coverage exceed that amount of coverage required to pay the sums secured by this Deed of Trust.

The insurance carrier providing the insurance shall be chyosen by Borrower subject to approval by t.ender: provided. that auch approval shr'l not be unreasonably withheld. All premiums on insurance policies shsll be paid in the manner provided under parap .ph 2 hereof or, if not paid in suci manner, by Borrower makins paymen:. when due, directly 10 ihe ssurance carrier.

A!! insurance policies and renewals thereof $x^{*} \cdot \vec{b}$ be in form acceptable to Lender and shall include a atandard mortgaze clause in favor of and in form acceptable to Lender. Lender shait have the rigtht to hold the polizies and renewals thereor. and Borrower shall promptly furnish to Lender all renewal notices and all receipts of paid premitms. In the event of loss. by Borrower.

Unless Lender and Borrower otherwise agree in writing. insurance proceeds stall be applied to restoration of repair of the Property damaged, provided such restorntion of repair is economically feasible and the security of this Deed of Trust is not thereby impaired. If such restoration or repair is nol economically feasible of if the security of this Deed cI Trust wowld be impaired, the insurance procecde shall be appliced to the sums secured by this Deed of Trust, with the excess, if any, paid to Borrower. It the Properiy is abandoned io Borrower, or if Borrower fails to respond to Lender within 30 days fron the date notice is mailed by Lender to Botrower that the insurance carrier offers 10 sette 2 claim for insurrance benefits, Lende: is authorized to collect and apply the insuraner proceeds at Lender's option either to restoration or repair of the Prorstry or to the sums secured by this Deed of Trust.

Unless Lender and Borrower otherwise r.gree in writing. an: such application of proceeds to principal shall not extend or postpene the due date of the monthly insisllments referred to in paragraphs 1 and 2 hereof or change the amount of such installments. If under paragraph IK hereof the Property is acguired by Lender, all right, title and interest of Borrower in and to any insurance policies and in and to the proceeda thereof resulting from damage to the Froperty prior to the sale or acquisition ahall pass to Lender to the extent of the sums secured by this Deed of Trust immediately prior to such sale or 6. Prestion.

6. Preservation and Maintenasce of Property; Leaseholdas Condominlums; Planned Unit Developments. Borrower shall keep the Property in good repaiz and shall not commit waste of permit impairment or Leterioration of the Property and thall comply with the provisions of any lease if this Deed of Trust is on a leaschold. If this Deed of Trust is on $\mathrm{n}$ unit in a condominium or a planned unit development, Borrower shalf 545 orm all of gorrower' a obligations under the declaration or covenanis creainng of governing the condominium or pianned unit developenent, the by-laws and regulations of the condominium of planned unit development, and constiluent documents. If a condominium or planned unit development hall bo incorporated into and shull nmend and aupplement the covenonis nus ogreenents of this Decd of Trust os if the rider were a part hereol.

7. Protection of Lender'a Securlty. If Borrower falls to perform the covenants and agreements conntained in thes Dees of Truat, or if any action or proceeding is commeneed which materially affects l.ender's interest in the Property. including, but not limited io, eminent domain, Insolvency, code enforcemert, or arrangements or procecdinge involving a bankrupi or decedent, then Lender at Lender's op:ion, upon notice to Borrower, may make such oppearances, disburse such sums and take such action as is necesary to protect Lender's interest, including. hut not limited to. dishursement of reasonable attorney's fees and entry upon the Properiy to make repairs. If Lender required mongage insurance as a condition of making the loan secured by this Deed of Truat, Borrower shall pay the preniums required to maintain sweh insurance in effect untll such time as the requitement for such insurance terminates in aecordance with Borrower's and t.ender'a writien agreement or applicable law. Borrower ahall pay the amount of all mortgage insurance prentiums in the manner provided under paragraph 2 hersol.

Any amounts disbursed by Lender pursuant to this paragraph 7, with interest thereon, shall become additional Indebiedness of Botrower secured hy this Deed of Trust. Unless Borrower and I.ender ogree to other ternis of payment, such. amounis shall be payable upon notice from lender to Borrower requesting payment therent. and shall bear inierest from the date of diburrement at the rate payable from lime to time on outstanting principal under the Note unless payment of Interest at auch rate would be contrary to applicable law, In which event such amounts thalt hear interest at the highest rate
perminalble under applicable law. Nothing contained in this paragraph 7 shall require Lender to Incte any expense or take any action hereunder.

A. Inapection. i.ender may make or cause to be mado renkanable entries upon and inspections of the Property. provided that Lender shatl give Borrower notice prior to any such inspection specilying reasonabie cause therefor relaied ti l.ender's intereat in the Propertv. 
9. Condemnaton. The procects of any aword or alaim for dainsges. direct or consequential. in connection with any condemnation or othep lakinz of the Propenty, or part thercof, or for conveyance in lieu of condemnation, are hereby assigned and shall be paid to Lender.

In the ovent of a total taking of the Properiy, the preseeds shall be applied to the sums secured by this Deed of Trust. with the excess, if any, paid to Borrower. In the event of a partial taking of the Property, "inless Borrower and Lender as is equal to that proponion which the amount of the surns sceured by this Deed of Trust immediately prior to the date of taking bears to the fair market value of the Property immediately ptior to the date of taking. with the balance of the proceeds paid to Borrower.

If the Property is abandoned by Borrowsr, or if. after notice by Lender to Burtower that the conderanor offers to make an award or settle a claim for damages, Borrower fails to respond to Lender within 30 days after the date such notice is mailed, I.er,der in nuthorized to collect and apply the pro

Property er to the sums secured by this Deed of Trust.

Unless Lender and Borrower otherwise agree in writing. any such application of proceeds to principal shall not extend or postpone the due date of the pounthly installments referred to in paragraphs 1 and 2 hereol of change the amount of

such installiments.
10. Borrower Not Relezsed. Extension of the time for payment or modification of amortization of the sums sectired by this Deed of Trust granted by Lender to any suecessor in interest of Borrower shall not operate to release, in any manner. the liability of the eriginal Borrower and Borrower's suecessors in interest l.ender shall not be required to eornmence proceeding against such suecessor or refuse to extend time for payment or otherwise modify amortization of the sums secured by this Deed of Trust by reason of any demand made by the original Borrower and Borrower s successors in interest. 11. Forbearance by Lender Not a Walver. Any forbearnnec by Lenter in exercisin\& any rizht of remedy hereunder. O otherwize afforded by applieable law, shall not he a waiver of or preclude the exercise of any such right of remedy. The procurement of insurance or the payment of taxes or other liens or charges by

ight 10 aceelerate the maturity of the indetiedneas secured the Deed of Trust are distinct and cumulative to any other righ or remedy suceessively.

13. Successorz and Assigns Bornd; Jolnt and Several Llabmity; Captions. The covenants and agreements hercin contained shall bind, and the rights hereunder shall inure to, the respective sueecssors and assigns of 1.ender und Borrower. subject 10 the provisions of paragraph 17 hereof. All covenanis and agreements of Borrower shall be joint and several.
The eaptions and headings of the paragraphs of this Deed of Trust are for convenience only and are not to be used to The captions and headings of the paragrap

14. Notlce. Except for any notice required under applicable law to be given in another manne-. (a) any notice to Borrower provided for in this Deed of Trust thall be given by mailing such notice by certified mail addressed to Borrower at the Property Address or at such other address us Borrower may designale by notice to Lender as provided herein, and (b) any notice to Lender shall be given by certifed mail. seturn receipi requested, to Lender's address stated herein or 100 sueh oiher address as Lender may designate by notice to Borrower as provided herein. Any notice provided for in 11.95 Deed of Trust shall be deemed to have been given to Borrower or lender when given in the manner designated herein. 15. Uniform Deed of Trust; Governing Law; Severablitity. This form of deed of trust combines uniform covenants for national use and non-uniform covenants with limitad variations by jurisdiction to constitute a uniform security instrumen covering real property. This Deed of Trust shall he governed by the law of thr jurisdiction in which the Property is located. In the event that any provision or clause of this Deed of Trust or the Note connticts with applicable law. auch confliet, hall riot affect other provisions of this Deed of Trust or the Note which cen be jiven eftect witho

and to this end the provisions of the Deed of Trust and the Note are declared the Note and of this Deed of Trust at the time of execution or after recridation hereof.

17. Transfer of the Property; Assumption. If all or any part of the Property or an interest therein is sold or transferred
andion of ater recridion hereof. by Borrower without Lenders prior wrilten consent. exsluding (a) the creation of a lien or encumbrance subordinate this Deed of Trust, (b) the ereation of a purchase money security interest for household appliances. (c) a Iransfer by devise. descent or by operation of law upon the death. of a joint tenant or (d) the gtant of any leasehold interest of three years or leas not :o.utaining an option to purchase. Lender may, at Lender's option. declare all the sums secured by this Deed of Trust to be imnicuiately due and payable. Lender thall have waived such opticn to accelerate if, prior to the sale or transfer. Lender and the person to whom the Property is :o be sold or Iransferred reach agreement in writing that he credit of such person is antisfactory to Lender and that the irterest payatie of the sums secured hy this Deed of Trust shall 30 at such rate as Lender thall reque it. in inierest has executed a writlen assumption agreement

II Jations under It Lender ezercises such option to accelerate. Lender shall mail Borsols 30 days from the date the notice is mailed within
aragraph 14 he:eaf. Such notice shall provide a period of not less than 30 such sums prior to the expiration of such period. which Borrover i:ay pay the sums declared due. If Borrover fails to pay such sums prior to the expiration of such peric

NON.JNIFONM COVEnANTs. Borrower and Lender further covenasit and ag:ee as follows:

i8. Acceleralion; Remedies. Except as provided in paragraph 17 hereol, upon Borrawer's breach of any covenant or nercement of Borrower In this Deed of Trust, Including the covenaints to pay when due sny sums secured by this Deed of Trust. Lender prior to acceleratlon shall mall notice to Borrower as provided in parazraph 14 hereof specifying: (1) the breach; (2) the acilion required to cure such breach; (3) a dale. rol less than 30 days from the date the notice is malled 10 Borrower, by whleh such breach must be cured; and (4) that fallure to cure such breach on or before the date specified In the notice may. result in acceleration of the sums secured by this Deed of Truat and sale of the Property. The notice shall further inform Borrower of the right to reinstale atter weceleration and the right to bring a court action to asser the non-exlatence of n default or any other defense of Borrower to meceleration and sale. II the breach is not cured on or before the date specified in the notice. Lender at Lender's option may declare all of the sums secured by nt Trust to be immedialely due and payable wlthout further demand and may tnvoke the power of sale and any other remedies pernilited by applicablc law. Lender shall be entitied to collect all ressonable cosis and expenses in

remesles provided in thls paragraph 18, Including. but not limlied to, rearnabie attorney's fees. If the power of sale is invoked, Trustee shnil record a notice of detaull in each county in which the Property or some part thereof is localed and shall mail copies of sues nollce in the manner prescribed by uppliced by appllesble law. Trurtez shail

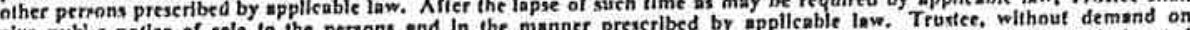
give public notice of nale to the persons and in the manner prescribed ty applicable lawe and under the terms designated

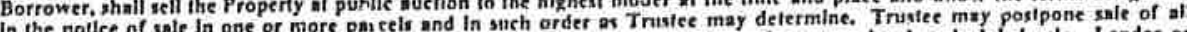
In the nollee of sale in one or more pai eels and in sich order as Tristee may determine. Trusiee may posipone sale of all or any parcel of the Property by public Einouncement at

Ger'a designee may purchace the Property at any sale. Upon recelpt of payment of the price ble. Trustee shall dellver to the purchaser Tristec's deed conveying ise Propenty shall npply the preceeds of the anle Io the following order: (a) to all reasonable costs whd expenese of the sale. including. But nut limlied io, Truatee's fees of not more than thereto.

19. Sorrower'n Right to Relnatate. Notwithstancling tender': acceleration of the sums secured iy this Decu of Trust. Bortrower shall have the tight to have any proceedings hegun by Lender to enforce this Deed of Trust discontinued a any time print to the earlier to eceur of (1) the nfth day hefore the vale of the P:onerry pursuant to the power of sale coniaine

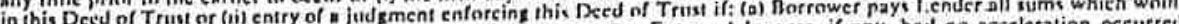
in then sue under this treed of Trust, the Note and noves eccuring Future Advances, if any, had no acceleration oceurted: (b) Borrnwer cures all hreaches of any ether covenants of azreements of Horfower cnntained in this Deed of Trust: (e) Horrower pays all rensanahic evpenses incurret by lender and Trastee in enforcing the covenanta and agrecments of

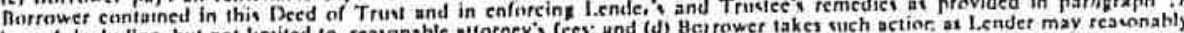

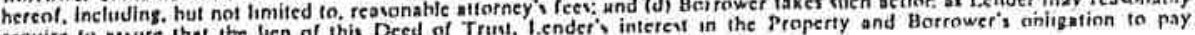
require to assure that the lien of this Deed of Trust. I.ender S intereat in the Property and Borrower's onigation to pay 
the sums secured by this Deed of Truat shall continuc unimpairet. Upon such payment and cure by Borrewer, this Deed of 20. Anignment of Rents; Appotntment of Recelver. Lull force and, effect as if no acceleration had occurred.

hereby assigns to Lender the rents of the Property, provided Lender in Possesslon. As additional security hereunder. borrower hereby assigns to Lender the rents of the Property. provided that Borrower shall, prior to acceleration under paragraph is

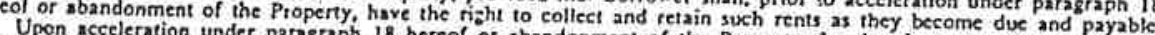
judiciafly acceleration under paragraph 18 hereol of abandonment of the Property. Lender, in person, by agent judicially appointed receiver, shall be cntitled to enter upon, take possession of and manage the Property and to collect the of on the cosis of manogement of the Property and collection of rents, including. but not limited to, receiver's fees preminen receivet thall be lias and reasonable attorney's fees, and then to the sums secured by this Deed of Trust. Lender and the 21. Future liable to account only for those rents actually received.

by Truatee to Borroweres. Upon request of Borrower. Lender. at Lender's option. prior to full reconveyance of the Property secured by this Deed of Trug maxe Future Advances to Borrower. Such Future Advances, with interest thereon, shall-be the principal smount of the indebed to protect the security of his Deed of Trust, exceed he Deed of Trust, not including wms advaneed in accordarce. herewith 22. Reconveyance.

the Properny and sell surrender to Trustec. Trustec shall reconvey the Property entitief thereto. Such perion or persons shall pay all costs whtranty and without charge to the person or persons legally 23. Subatilute Tratee. Lender, at Letion, if any.

trustee to any Trustec appointed hereunder by an instrument recorded in the county in whe Trustee and appoins a successor Without conveyance of the Properiy, the suceessor trustee hall succeed the county in which this Deed of Trust is recorded. sucessior trustee athall succeed to all the title, power and dutiea conferred upon 24, Request for Nothes Borrower

address which is the Property Address. requests that copies of the notiee of defoult and notice of sele be sent to Borrower"s

In Witness Wherzor. Borrower has executed this Degd of Trust.
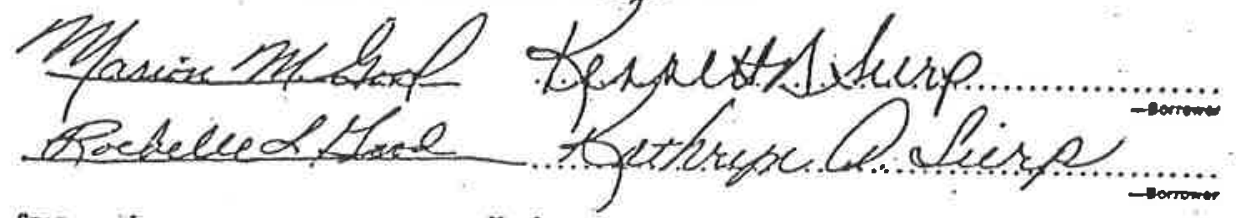

STSTE OF NEBXISYA, ............... York

York.

County is:

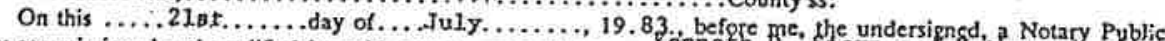

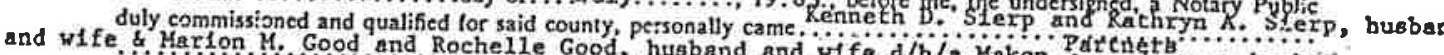

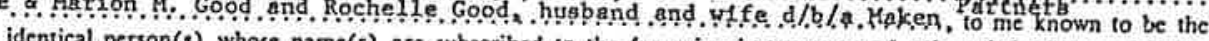
identical person(s) whose name(s) are subscribed to the foregoing instrument and acknowledged the execution thereot to be..... the t. ...... voluntary act and deed.

Witness my hand and notarial seal at........... York. date aforcsaid.

in szid county, the

My Commission expires: $2-13-1984$

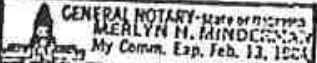

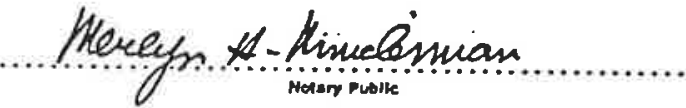

To TRUSTEE:

The undersigned is the holder of the note or notes secured by this Deed of irust. Said note or notes, together with all other indebtedness secured by this Deed of Trust, have been paid in full. You are hereby direeted to cancel said note or notes and this Deed of Trust, which are delivered hereby, and to reconvey, without warranty, all the eslate now held by yeu under this Deed of Trust to the persing or persins legaily entitled thereto.

Dete: 


\section{Copies of Titles}

York Heating and Air Conditioning (Formerly Lloyd's Body Shop) 


\section{[B67 Warranty Deed: Recerd: .

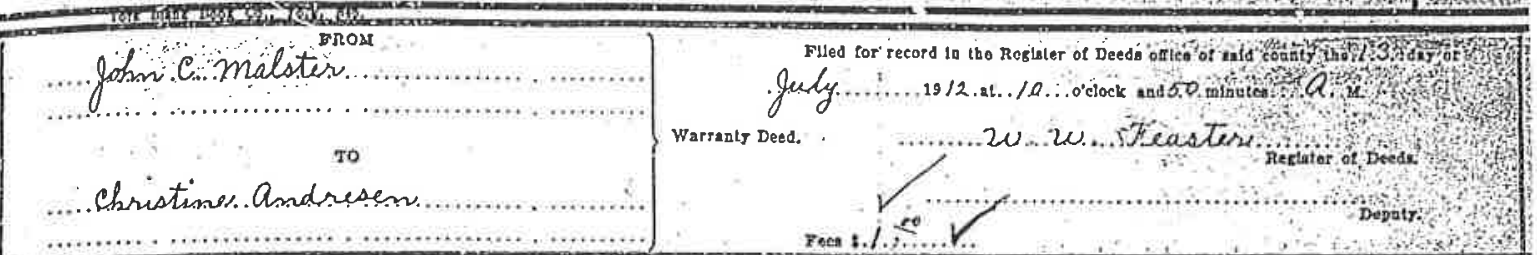

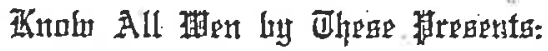

тват....... Grohn.e. malster.t......

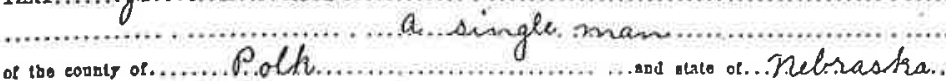

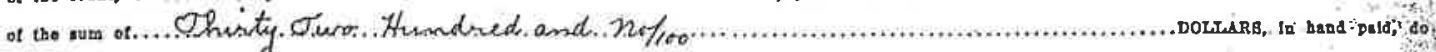

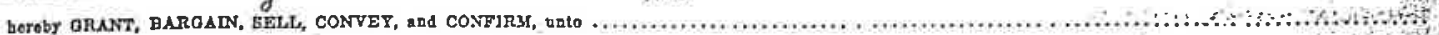

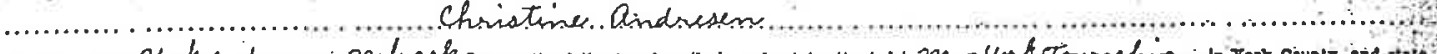

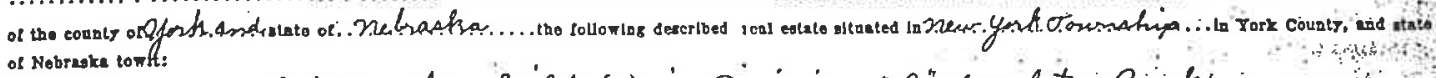

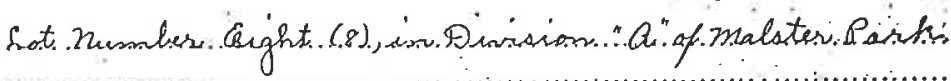

ad...........do bereby contenant with the said Chrid Thime Qradresem

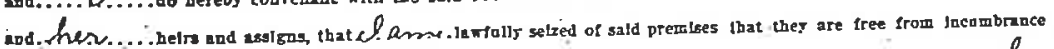

title to mald premisea agalant the la reful clalms it all persors mhorsoerer.

And the osid . .

bereby relligaulebo all

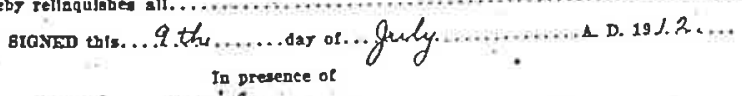

nathan. 2wilsons.

$$
\text { Gohm. C...malater................... }
$$

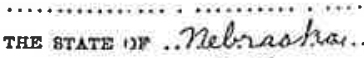

$$
\text { P.olh..............unts }\} \text { a. }
$$

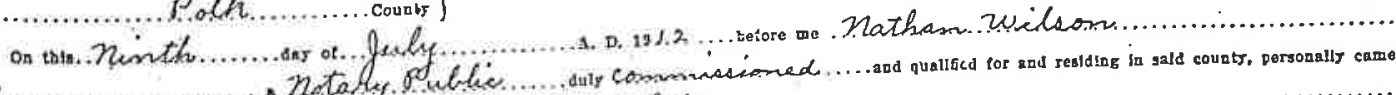

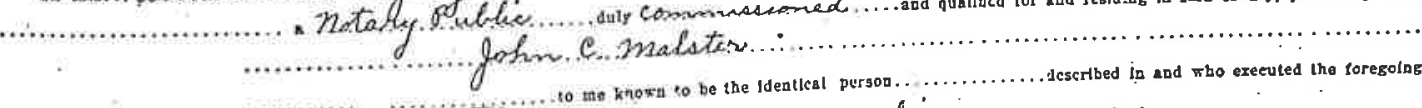

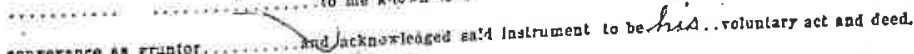

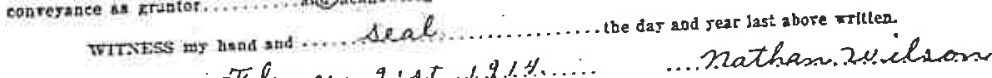

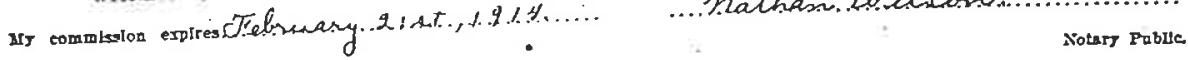

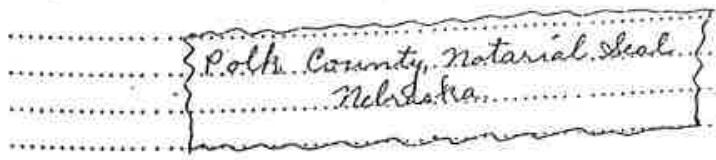




\section{$136 P$ \\ DEED RECORD $\beta 75$}

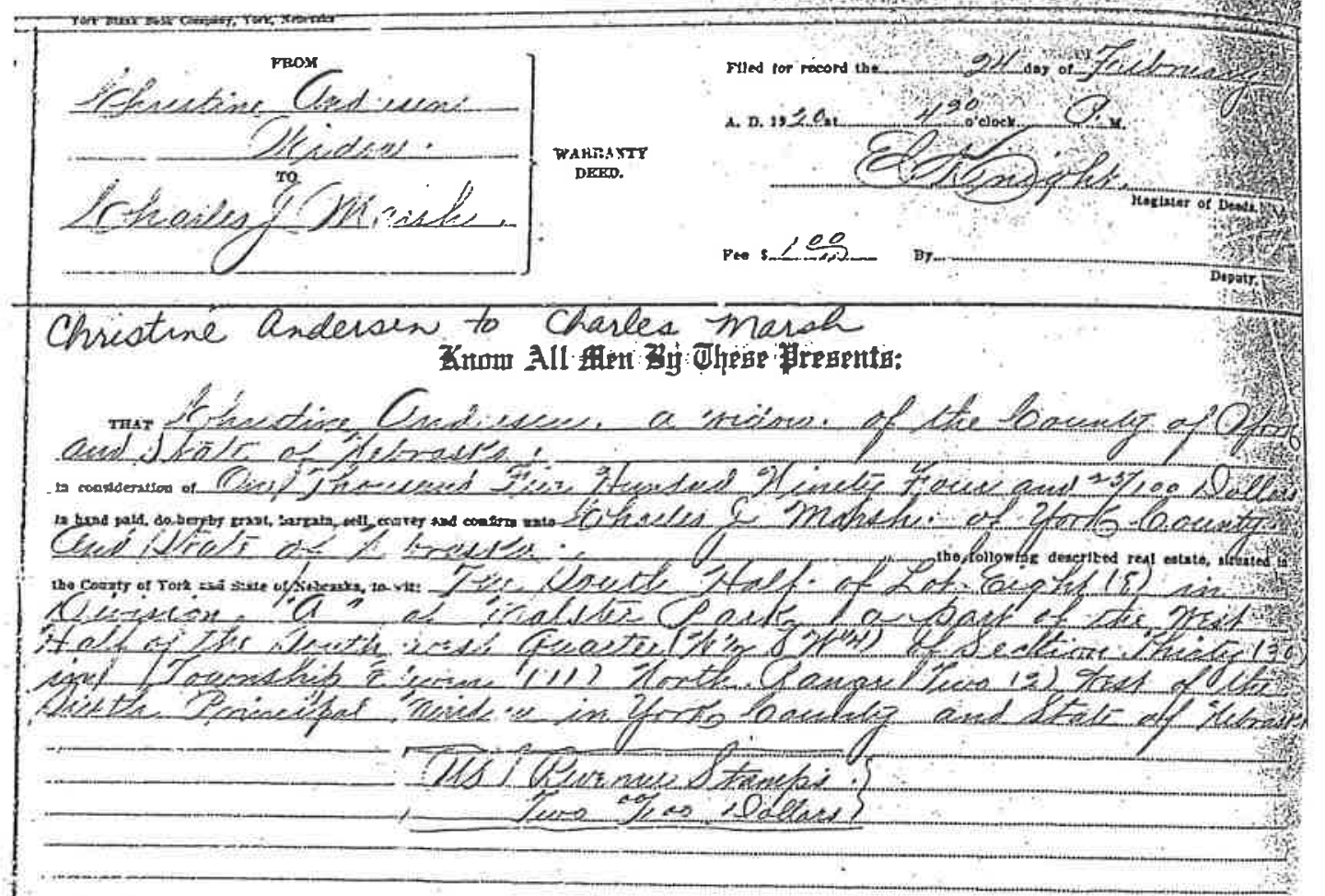

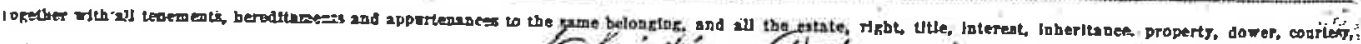

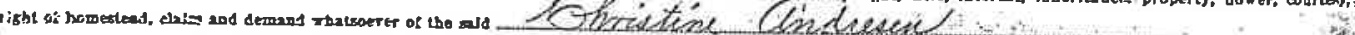
i $P$, to us to the reve, or ang par creteol:

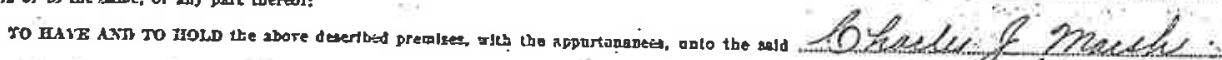

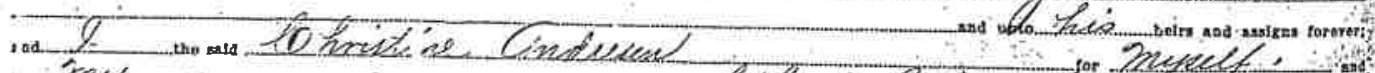

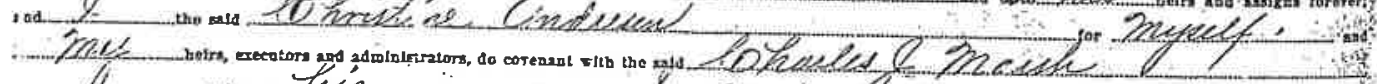

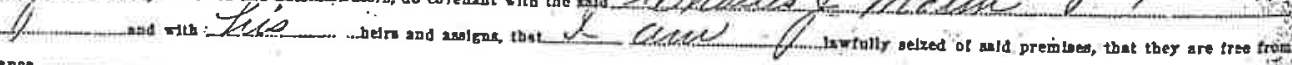
l let abrace

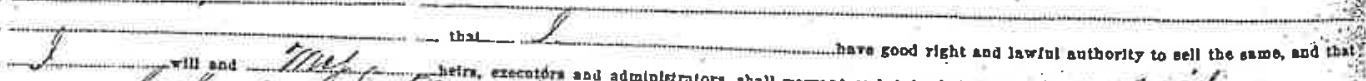

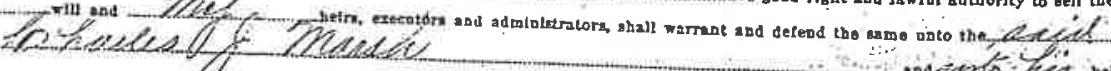

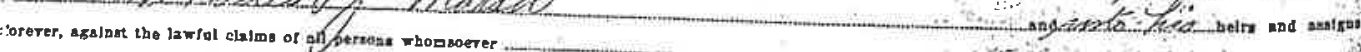

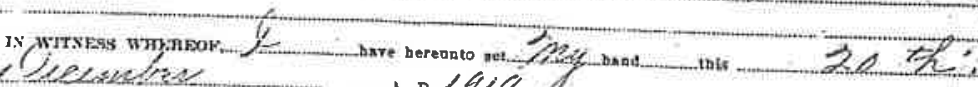

- Lecoulues

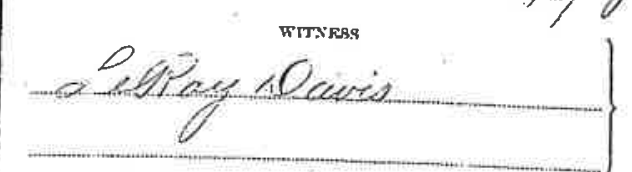

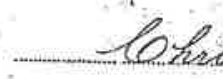

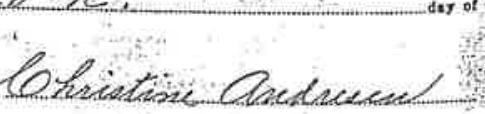

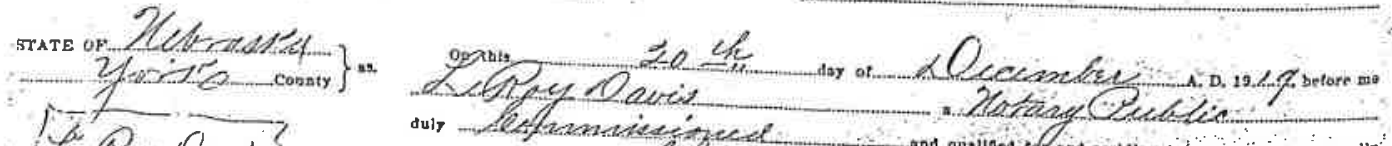
Poy Naris Pria nipen

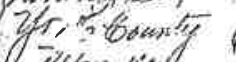
- iestowial

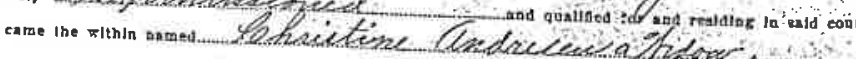
bo. 2 -

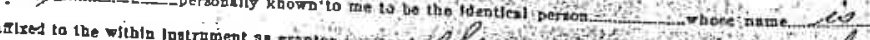

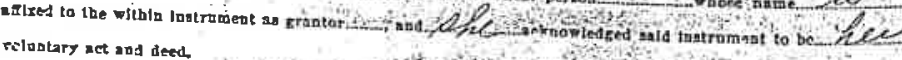

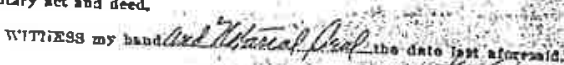

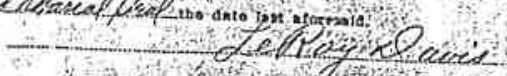
- Notars Publte.

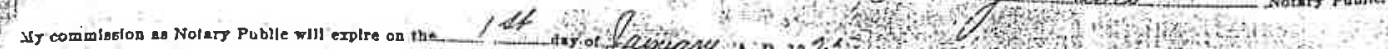

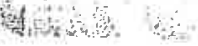




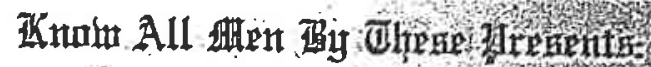

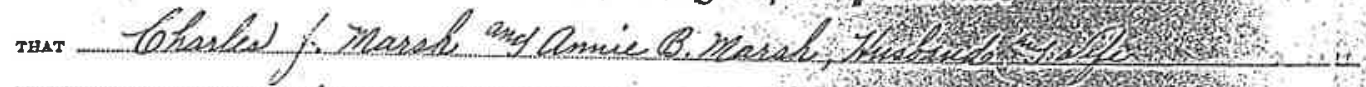

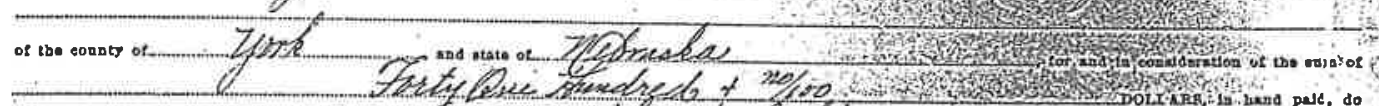

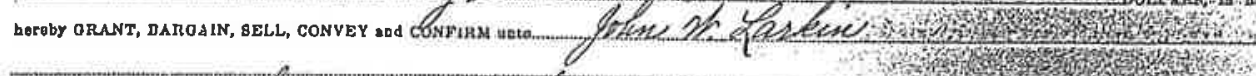

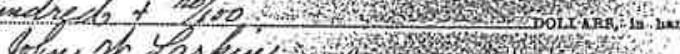

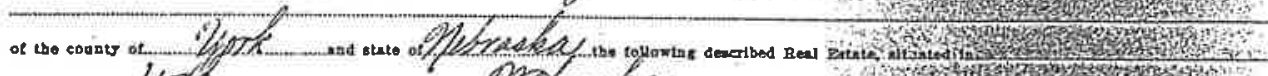

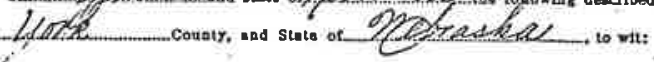

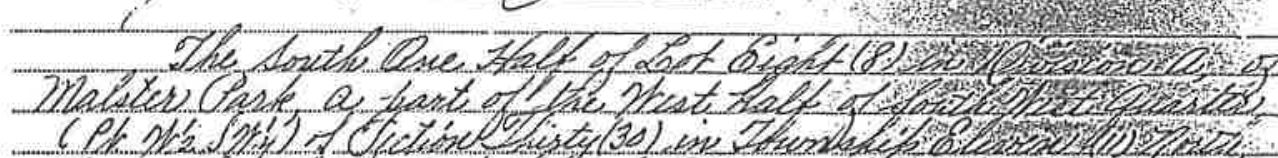

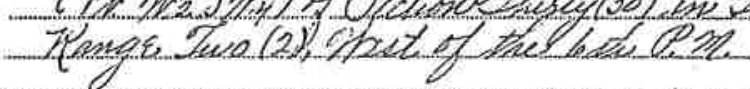

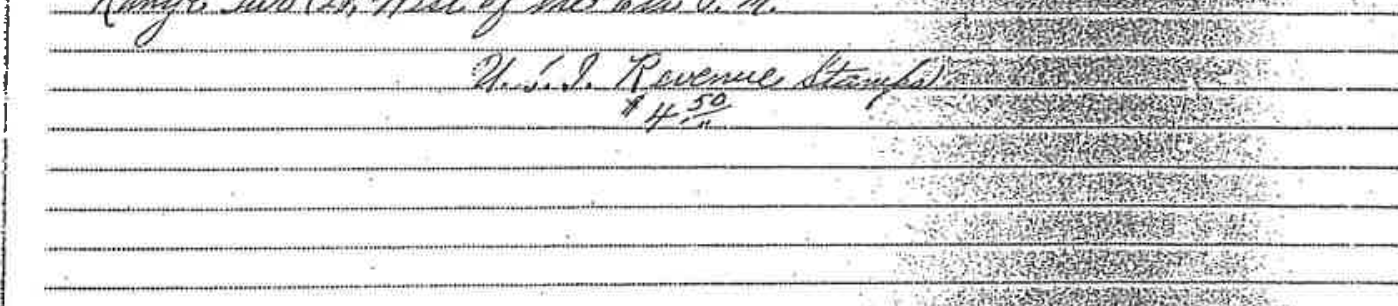

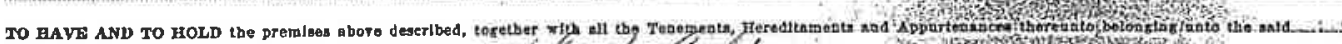

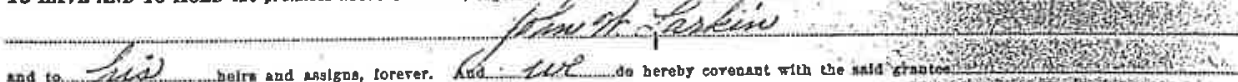

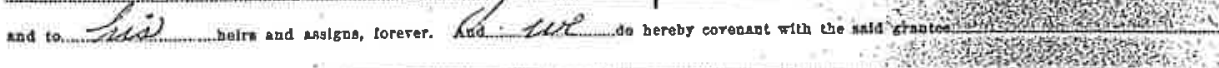

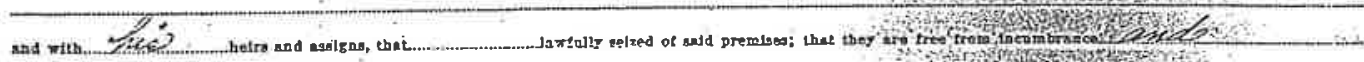

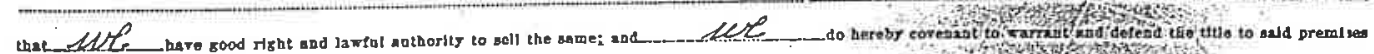

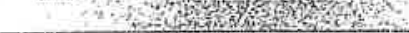

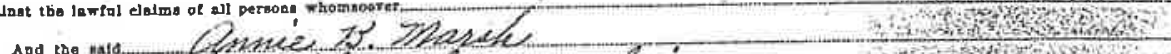

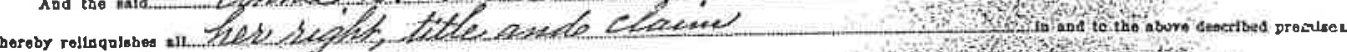

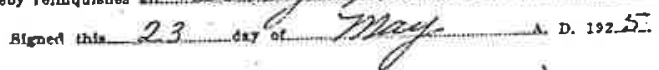

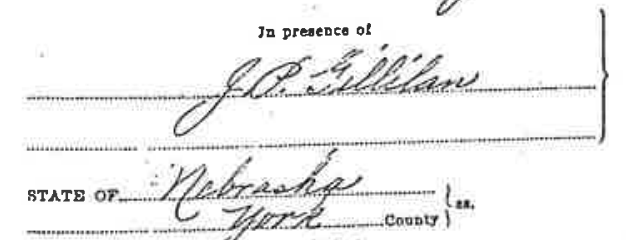

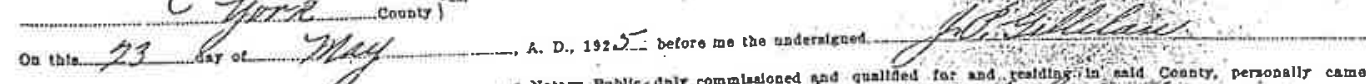

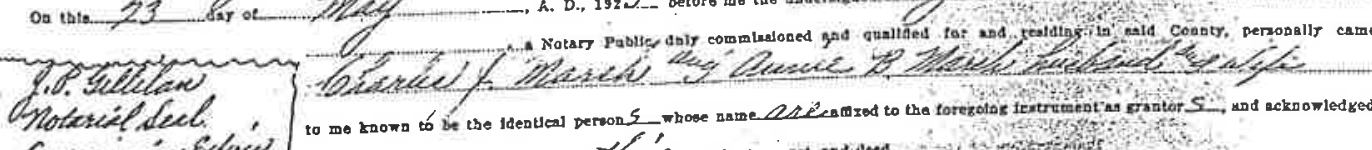

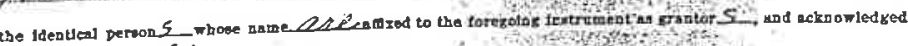
may 19, 1930 .

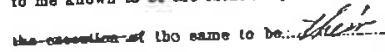

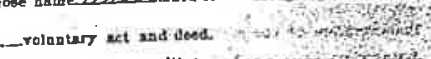

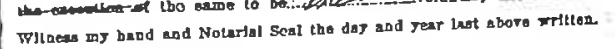
- $100^{-1}$ Q 


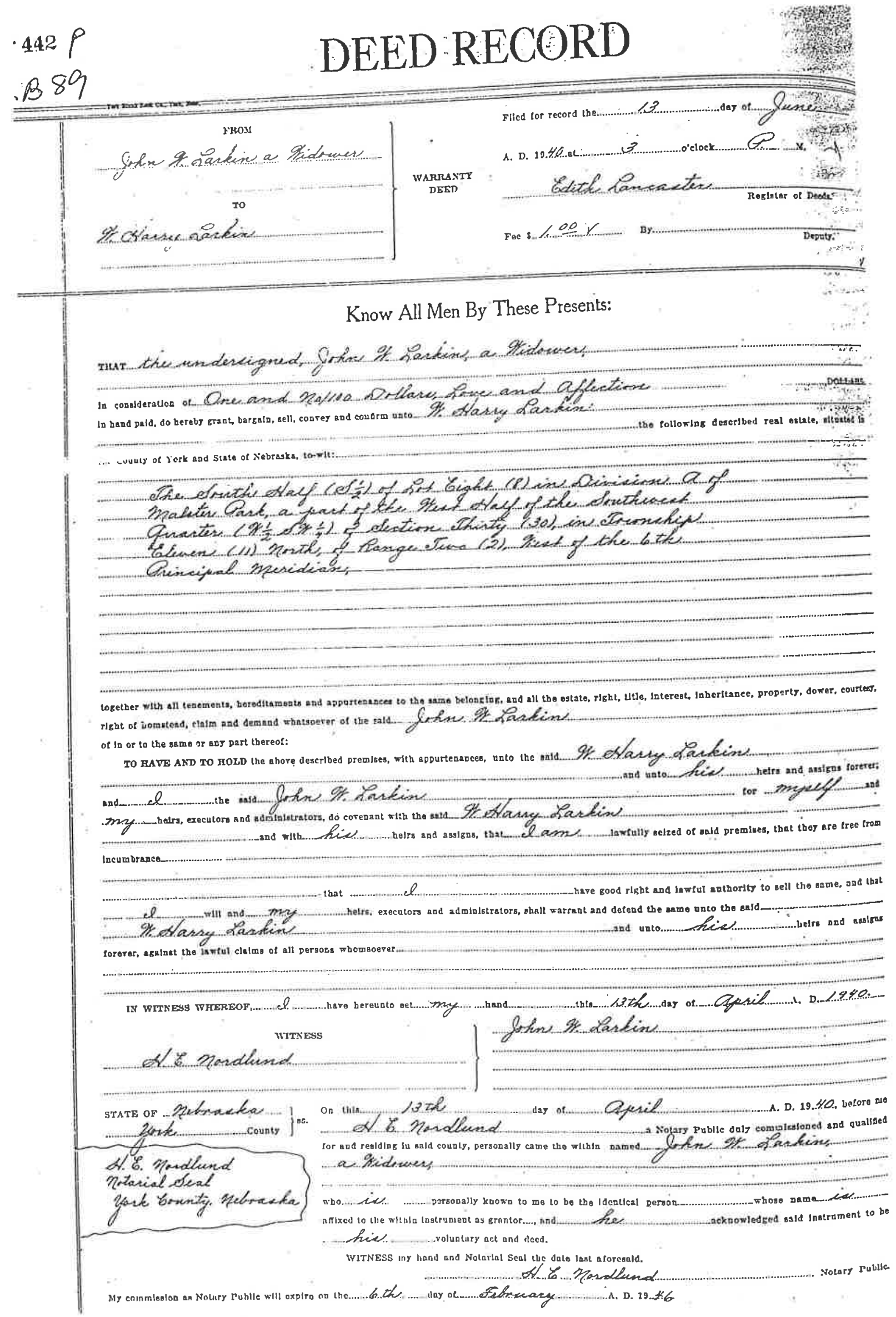




\section{Warranty Deed Record}

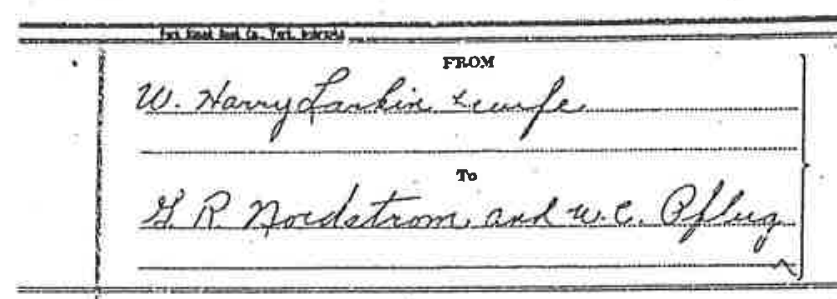

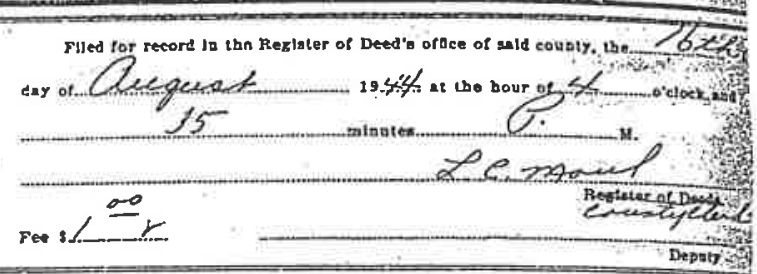

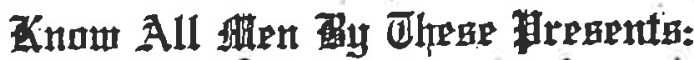

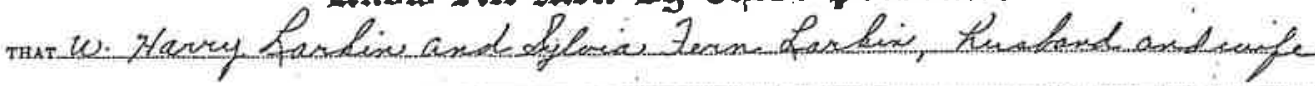

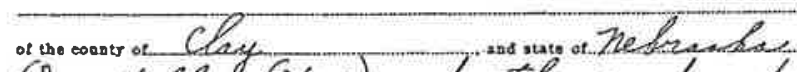

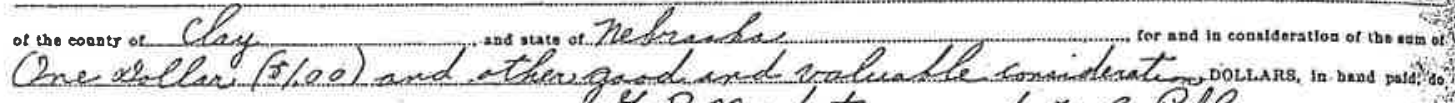

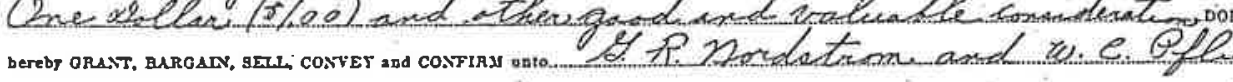

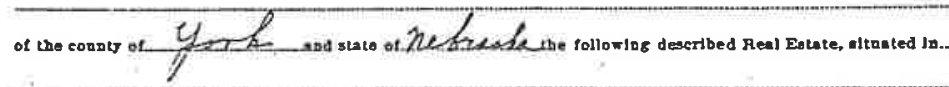
Tork Countr, and Sute of Nebrakk, to:vitit

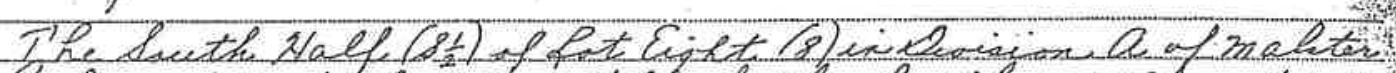

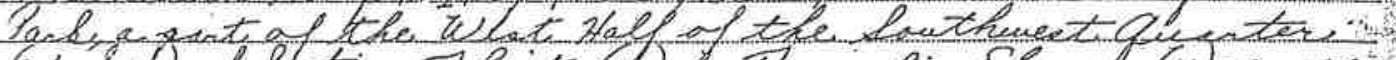

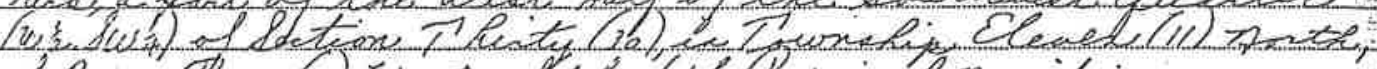

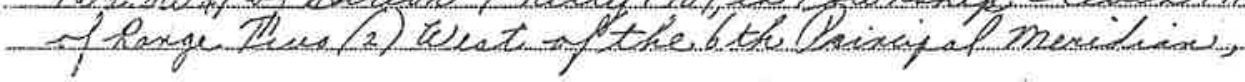

$$
\text { (1182 } 2 \text { Stampa } 2.20)
$$

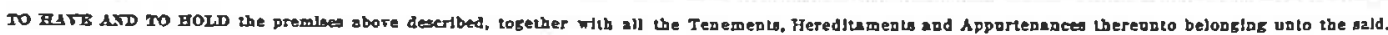
Tranterw.

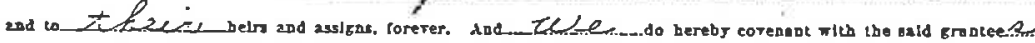

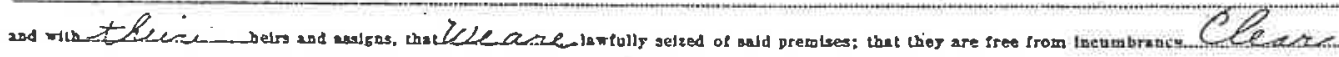

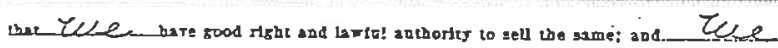

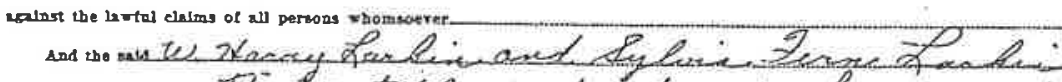

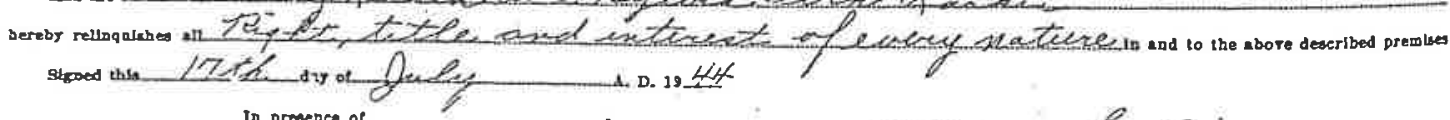
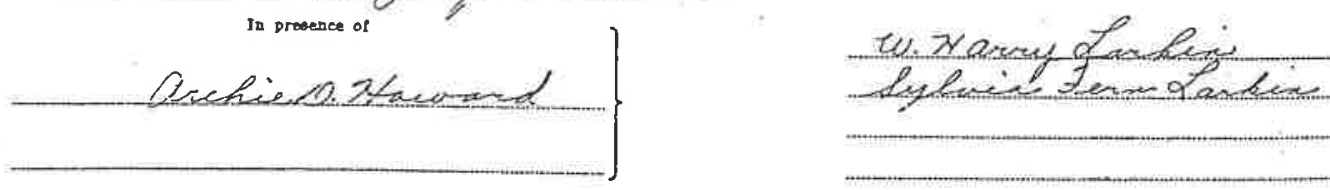

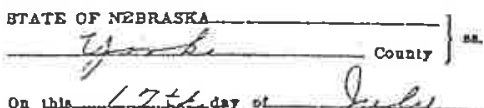

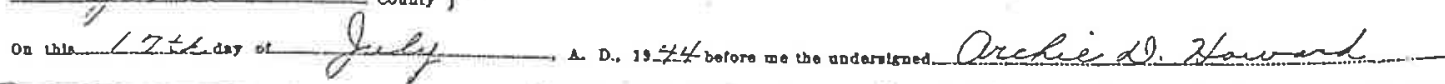

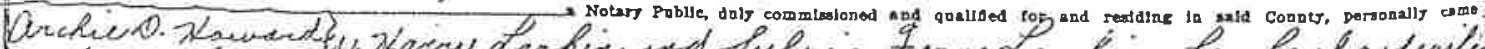

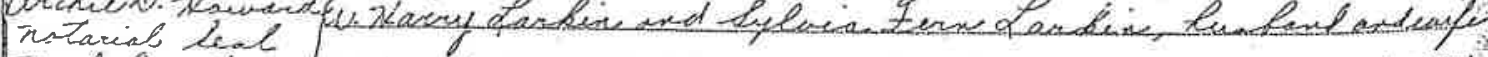

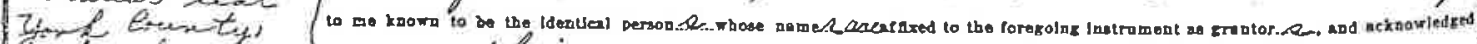

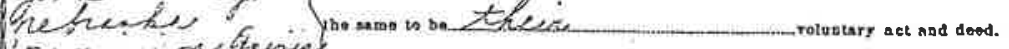

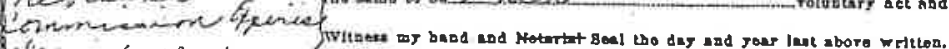

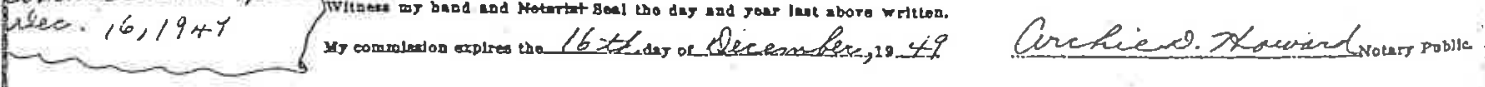




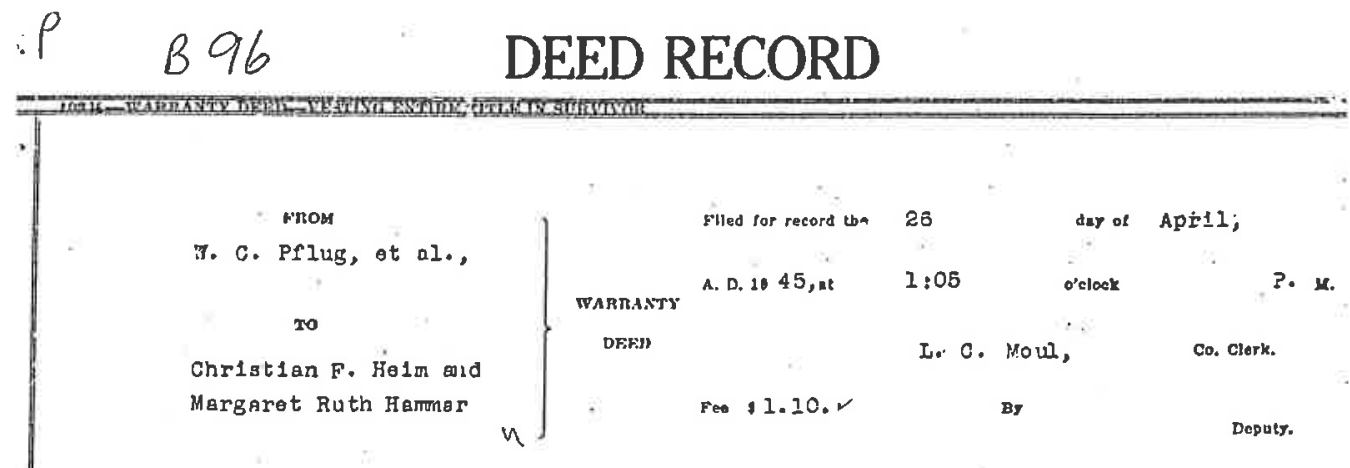

Know All Men By These Presents,

That W. C. Pflug and lamie A: Pflug, husband and w Ifo; O. R. Fordstrom ond Marig Nordstrom

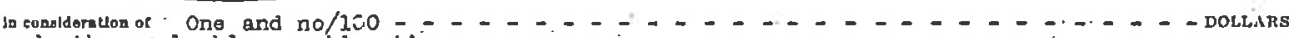
and other valuablo considuration:

as JOINT TENANT3, and not an tengats ls, eownon; the following deser/hed real estate, iftuated fa the County of Tork

thid gtate of Nebranka, tr-ivit:

South Half (Sk) of Lot Elght (B) in Divlsion A, Malster Park,

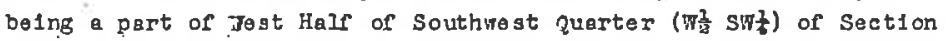
Thl rty (30), Township Ele ven (11) North, lange Tro (2) West of 6th P.M.

\section{(U. S: I. R. Stemps \$2.75.)}

togetber witb all the tenements, bereditaments, and appartenances to the same belonglng, nnd all the estate, tlle. dower, right of homestcnd, elalm or demand whateourer of the sald grantor $\mathbf{S}$, of, In or to the same, or ans part tbereat: $=$ atoders

IT DEING THE INTENTION OF ALL PARTIES HETETO, THAT IN THE EVENT OF THE DEATH OF EITHER OF SAID GRANTEES, THE EXITE FEE SIMPLE TITLE TO THE REAL ESTATE DESCRIDED HEREIN SHALL VEST IN THE SURVIVTFO GRANTEE.

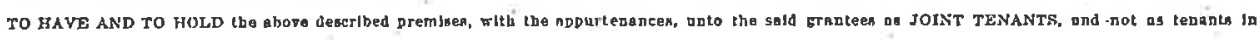
common, and to thelr asslgas, or to the heire and asalgas of the surtivor of them, forever. and we the gractor 9 named herela tor ourselves and our helrs, execotors, and administratora, do corenant with the grantees nawed hereln and will thelr absikns and with

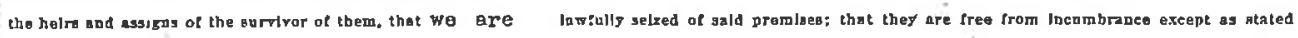

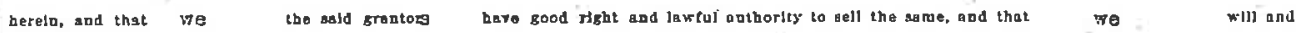
Dur hefrn, executors and adminlatrstorn slanll warrant god defend the same unto the grknlees named herela and unto thelr ansigns and unto thelr helrs and absigns of the urrivor of tbem. torerer, agninst the lartul cla!ms of all persons whomsoerer, excluding the exceptlons nyaned herefn. NN WITNESS WHEREOF Te hare hereunto set our hands thls 20 th March, A. D. 1945. tn prenence of

W. C. Pflug

C. Earl Jenkins

Mamio A. Pfjug

G. R. Niordstrom

STATE or Nebraske I Marle Nordstrom

County of York $\rightarrow$ kr: On thls 20th dng ne Mereh

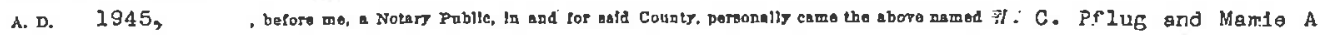
Prlug, husband and wife; G. R. Nordstom and Marlo Nordstrom, husband and vifo,

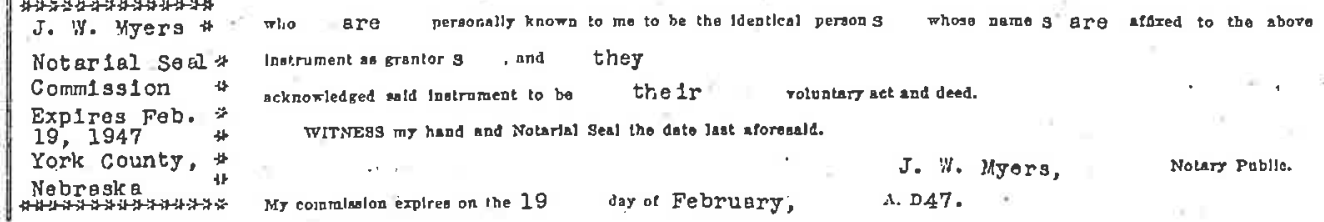




\section{DEED RECORD}






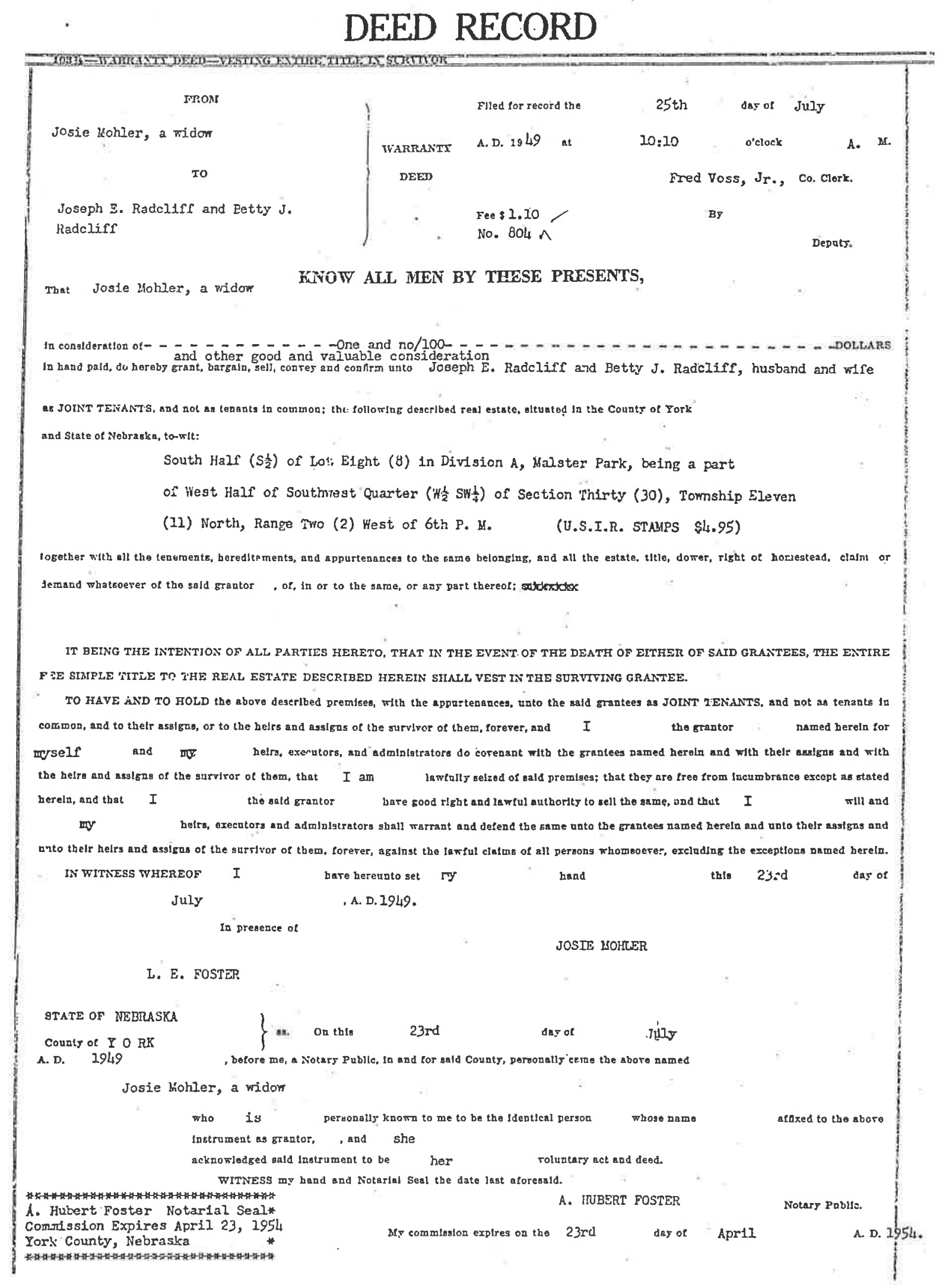




\section{$\because \quad$ DEED RECORD}

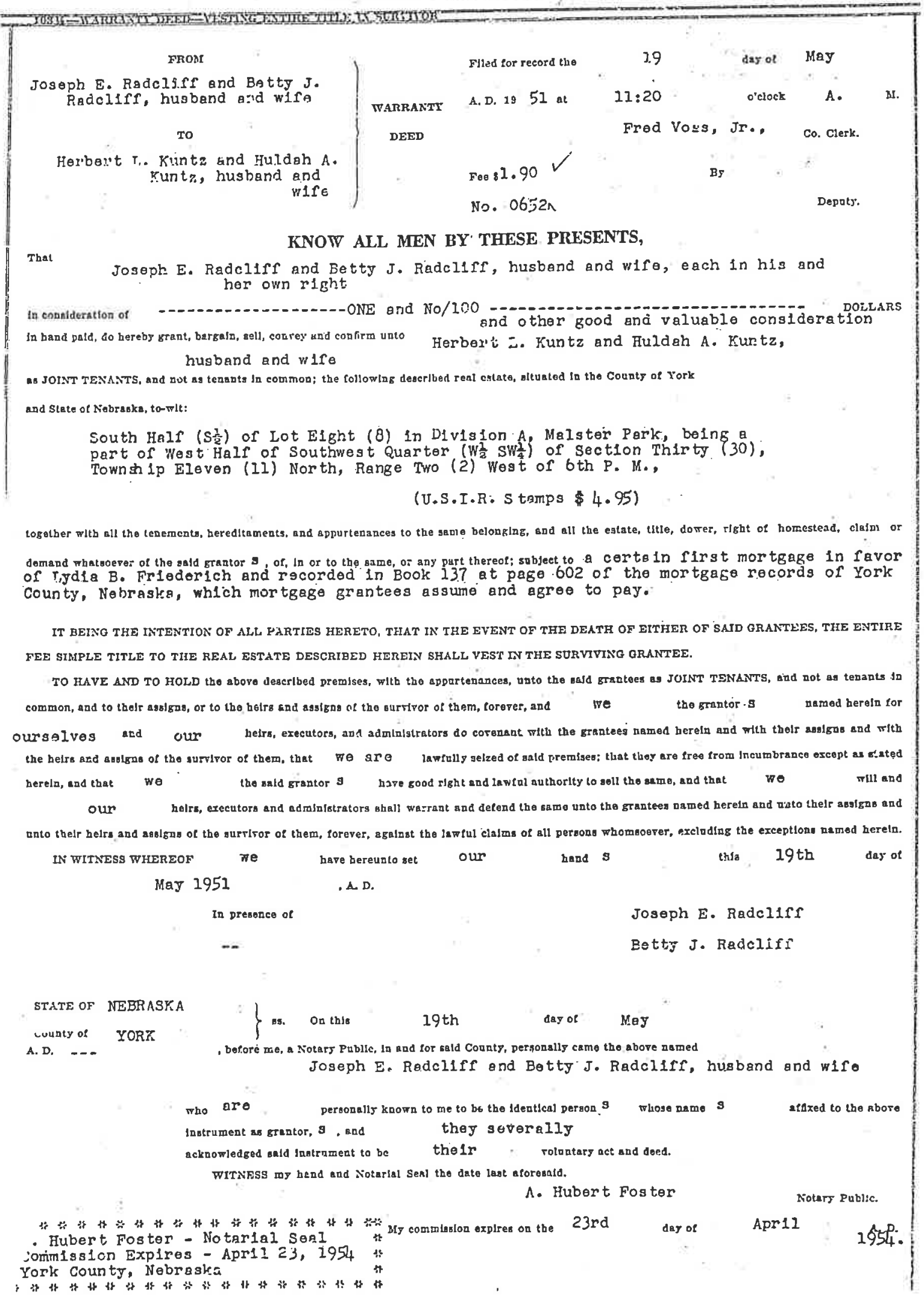




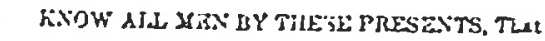

HER3ERT L. KUSTZ and FULDRH A. KLATZ, husband and wer,

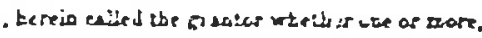

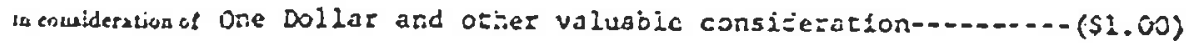

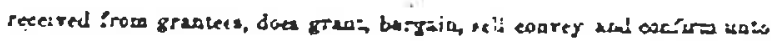

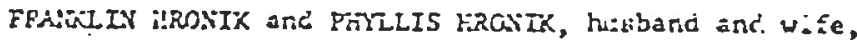

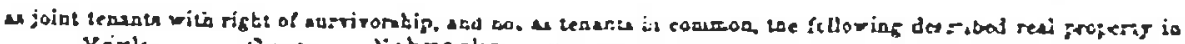
York liusty, Nebzaska

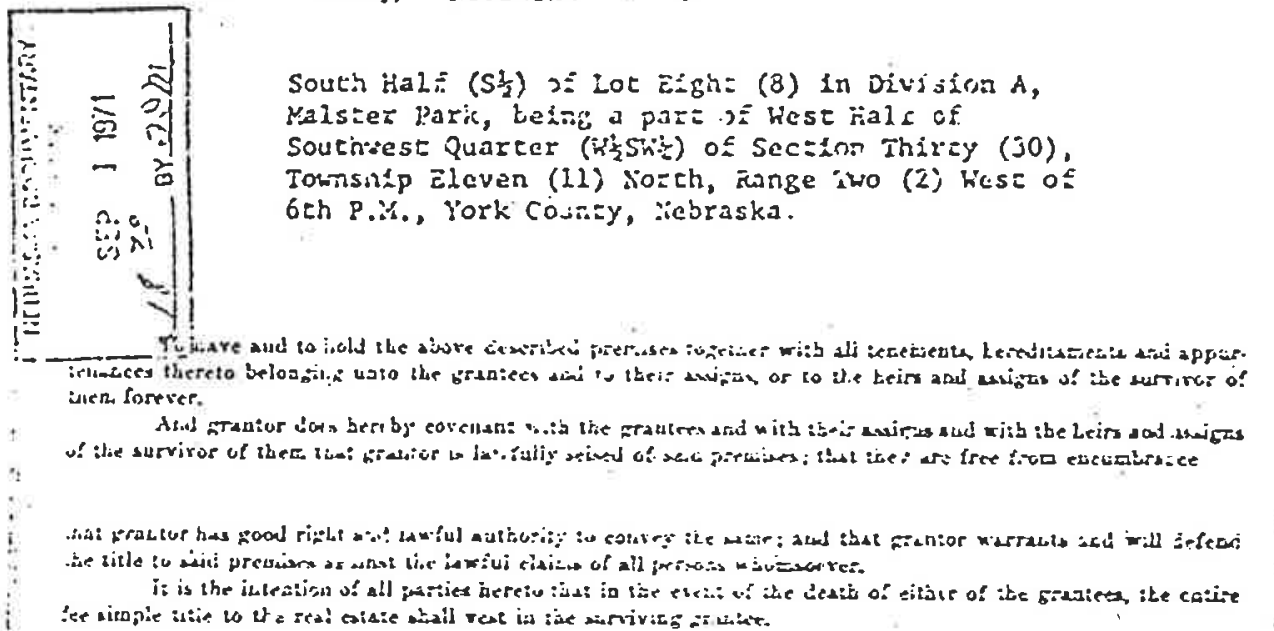

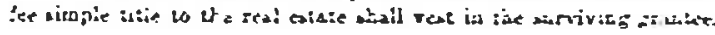

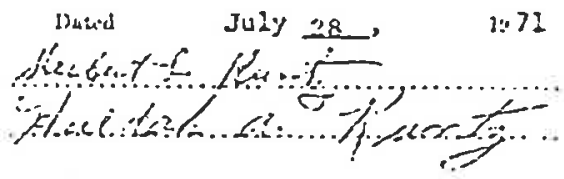

SIATE OF. NERRTARA

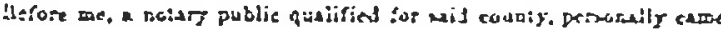

herbert L. Kurte and hulcas A. ت̈tanc=, husbanci and rife,

$\because n \therefore i$

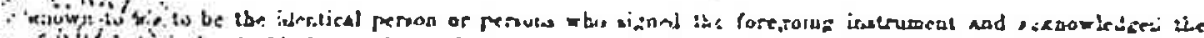

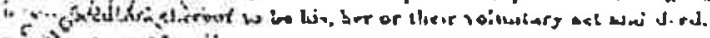

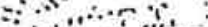

i.:.

.

$\because \because \gamma: x^{4} \therefore$

$\therefore c .1 \div:$

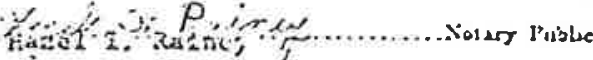

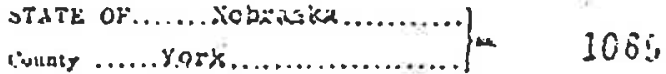

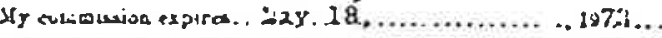

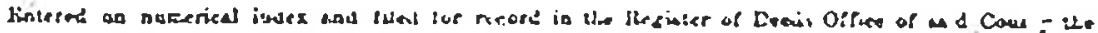

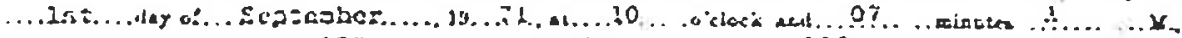

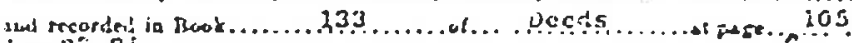
ict so. Es

$\therefore$ anditon

.. i. . .

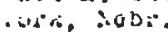

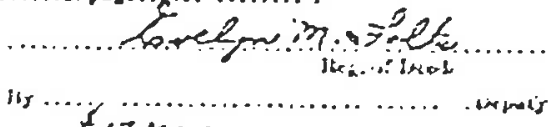

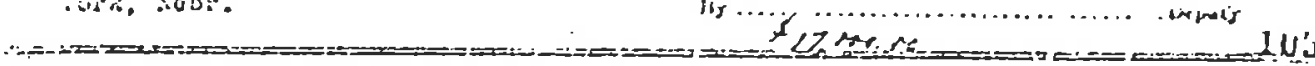




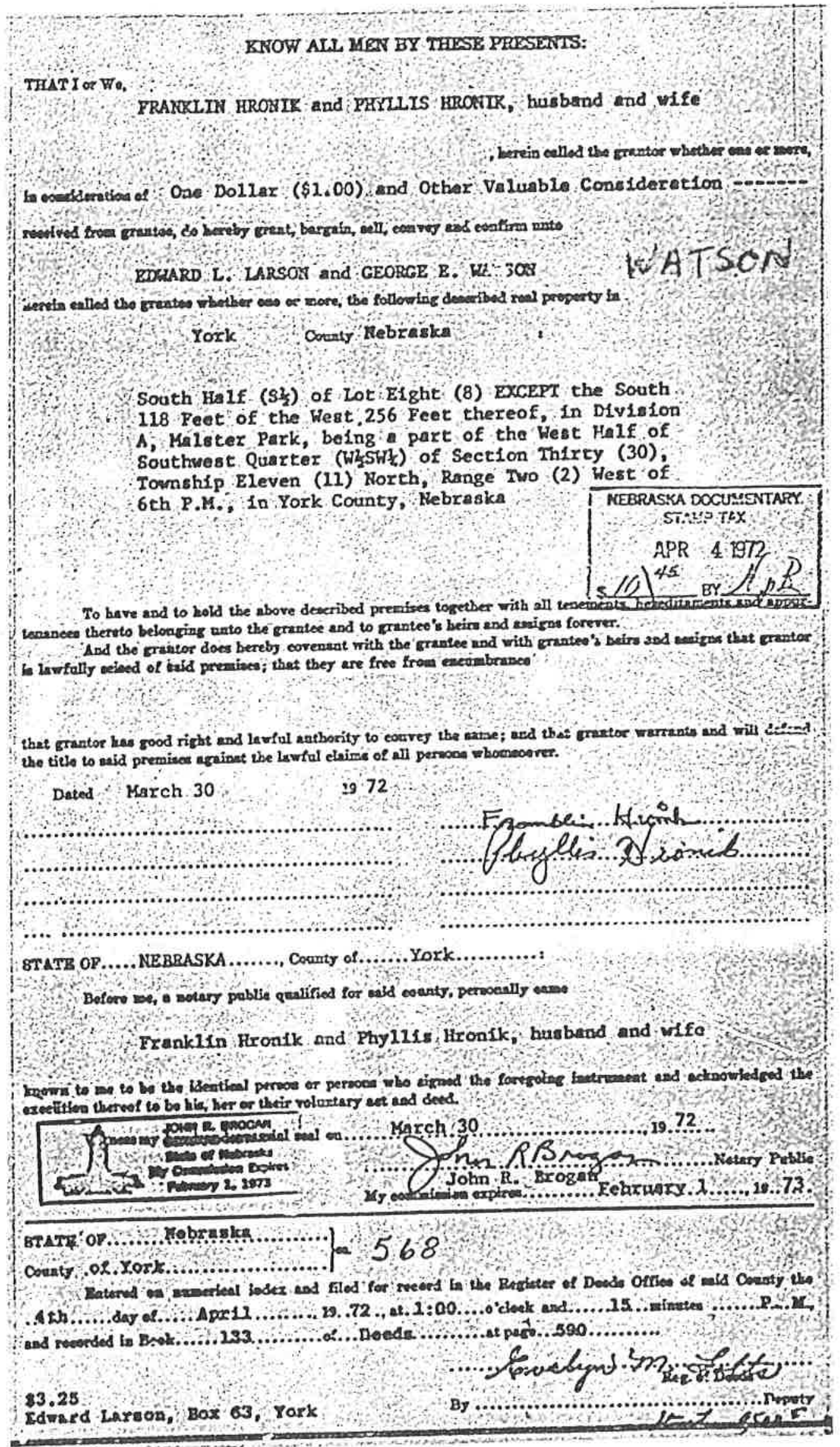




\section{KNOW ALI MEN BY THESE PRESENTS:}

THAT Ior Ke, GEORGE E. WATSON and MILDRED L: WATSOX, husband and wife; and CONSTAICE D. IARSON, a EIIISL person; and CONWE ThE LARSON, E IIOgle perEOD

, herein called the irantor whether ose or mare, in comaderation of One Dollar and other valuable conslderation - - . - recetied frow grantee, do hereby granh, bergain, well, eoavey and confirm wnto

BERNIE KLEIN, INC.

berein ealled the cranteo whether one or more, the following decribed real property in

York Counts Mebraska :

South Half (5\%) of Lat Eight (8) EXCEPT the South

118 feet of the Hest 256 . feet thereof. In Divialon A.

Malster Park, being a part of the Hest Half of Southest

Quarter ( $\mathrm{W}_{2} \mathrm{SW}$ ) of Section Thirty (30), Township Eleven

(11) North, Range Two (2) West of the 6th P.K.. In York

County, Nebraska

NEBRASKA DOCUMENTAFY
STHM? TAX
MAY 24 QT3
$12 e^{5}$ BY mb

To have and to hold the above deneribed premives togrther with all tenements, bereditaments and appar.

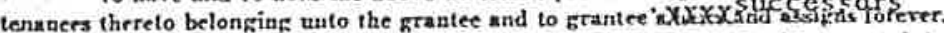

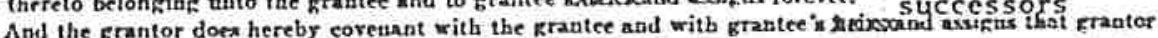
is tawfully seised of anid premises: that they are free from encutabrance except Ilen or potential ien of Water District No. 155 of the City of York whici grantee agrees to assume

that grantor han good right and lawful anthority to conrey the same; and that grantor varrants and will defend the title to maid premines against the lavful elaims of all pernons whomsoever.

Dated

April 20th

1973

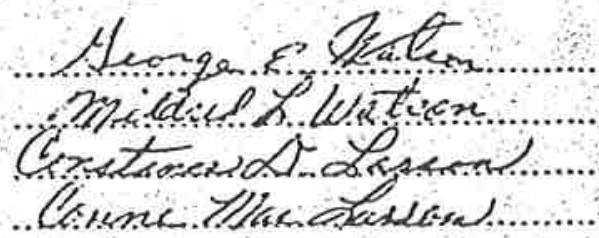

stite of....Nebraska County af...... York

Before me, a notary public qualified for seid county, perronally eame

George $\mathrm{E}$. Watson and Mildred L. Watson, busband and wife; and Constance D. Larson, a single person, and Conne Mae Larson, a single person

known to we to be the ideatieal pernon or perion wbo rigued the foregroing inatrument and acknowledsed the exeeviton thereof to be his, her or their voluntary act and dred.

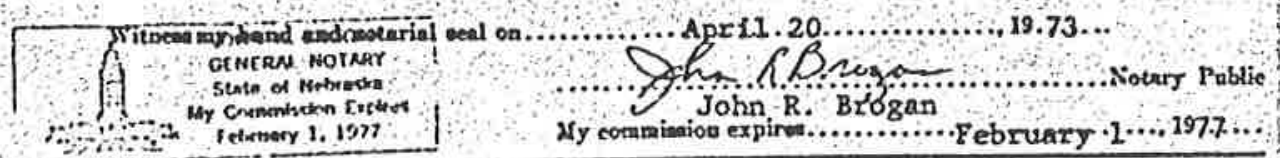

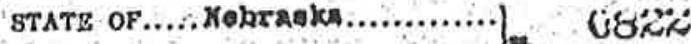

Counly ....Xork.

Entered on numerieal index and filed for reeord in the Reginter of D-ads Oftise of anid Coanty the

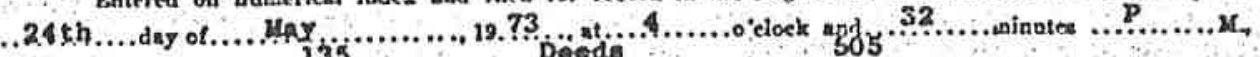
and rectis

Feo $\$ 3.25$

Ray svohlo

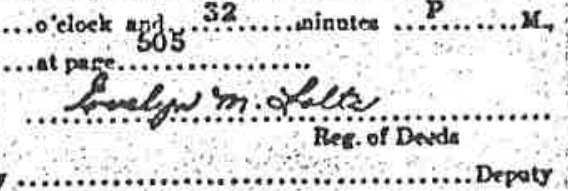




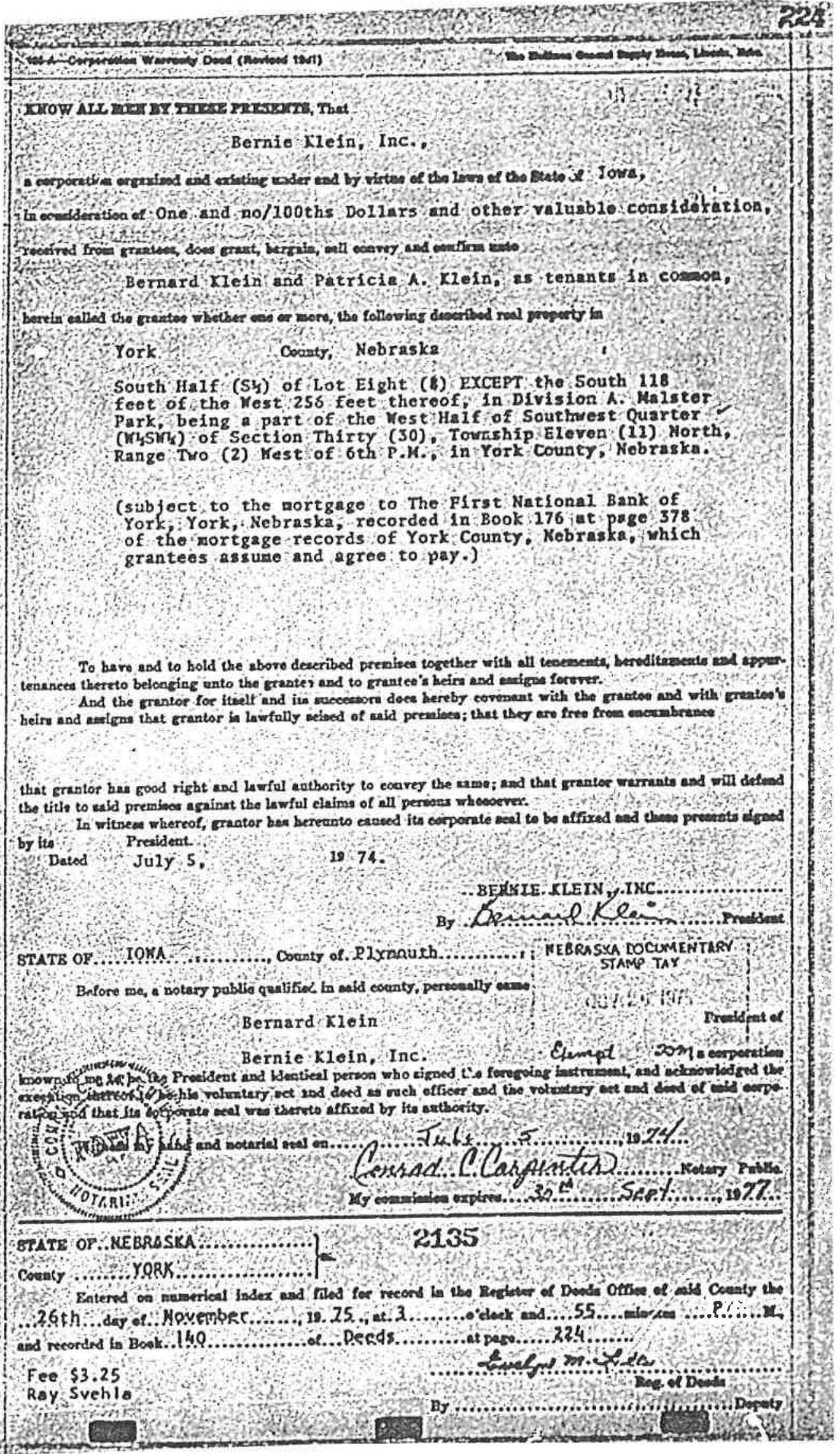




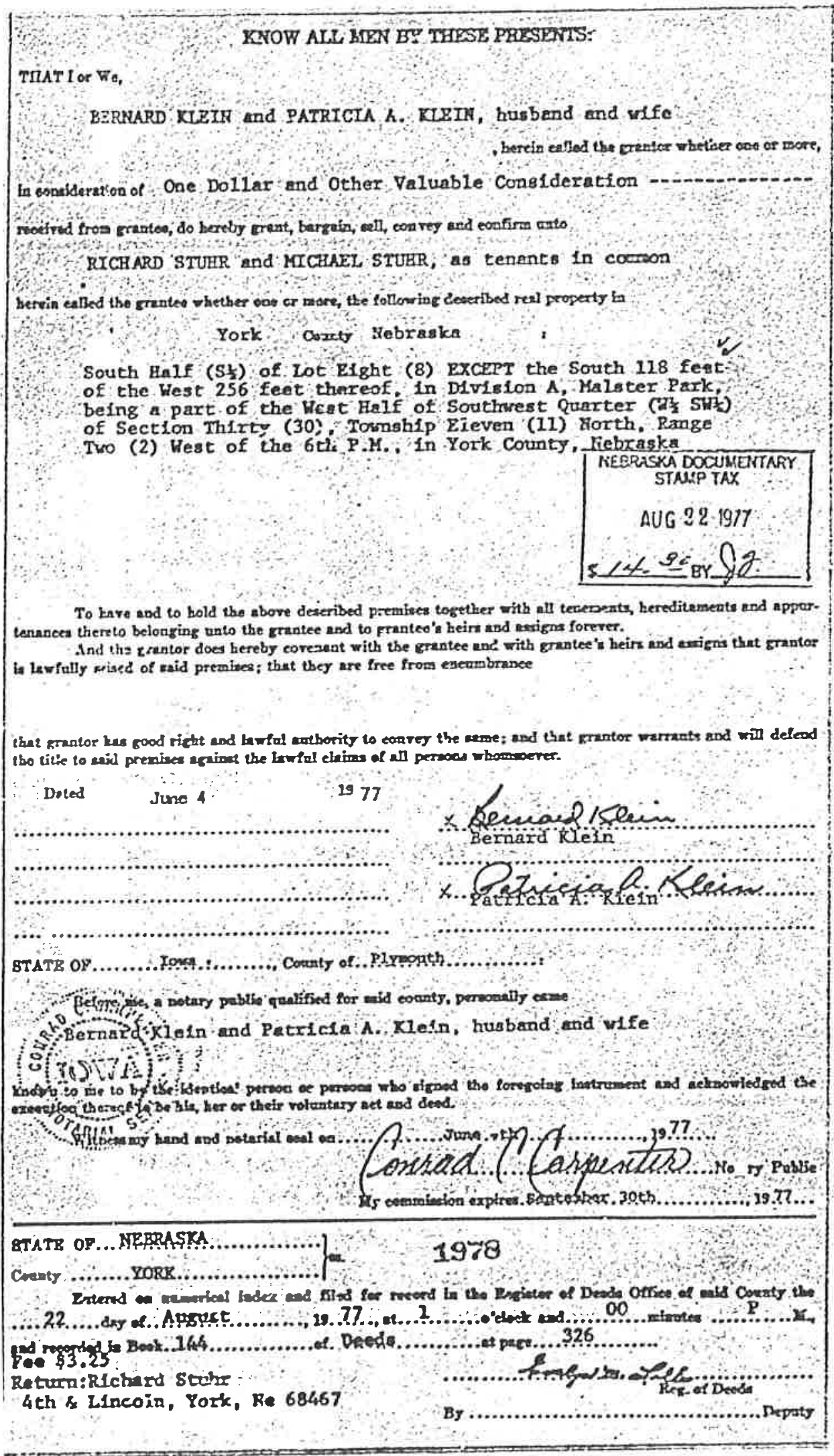




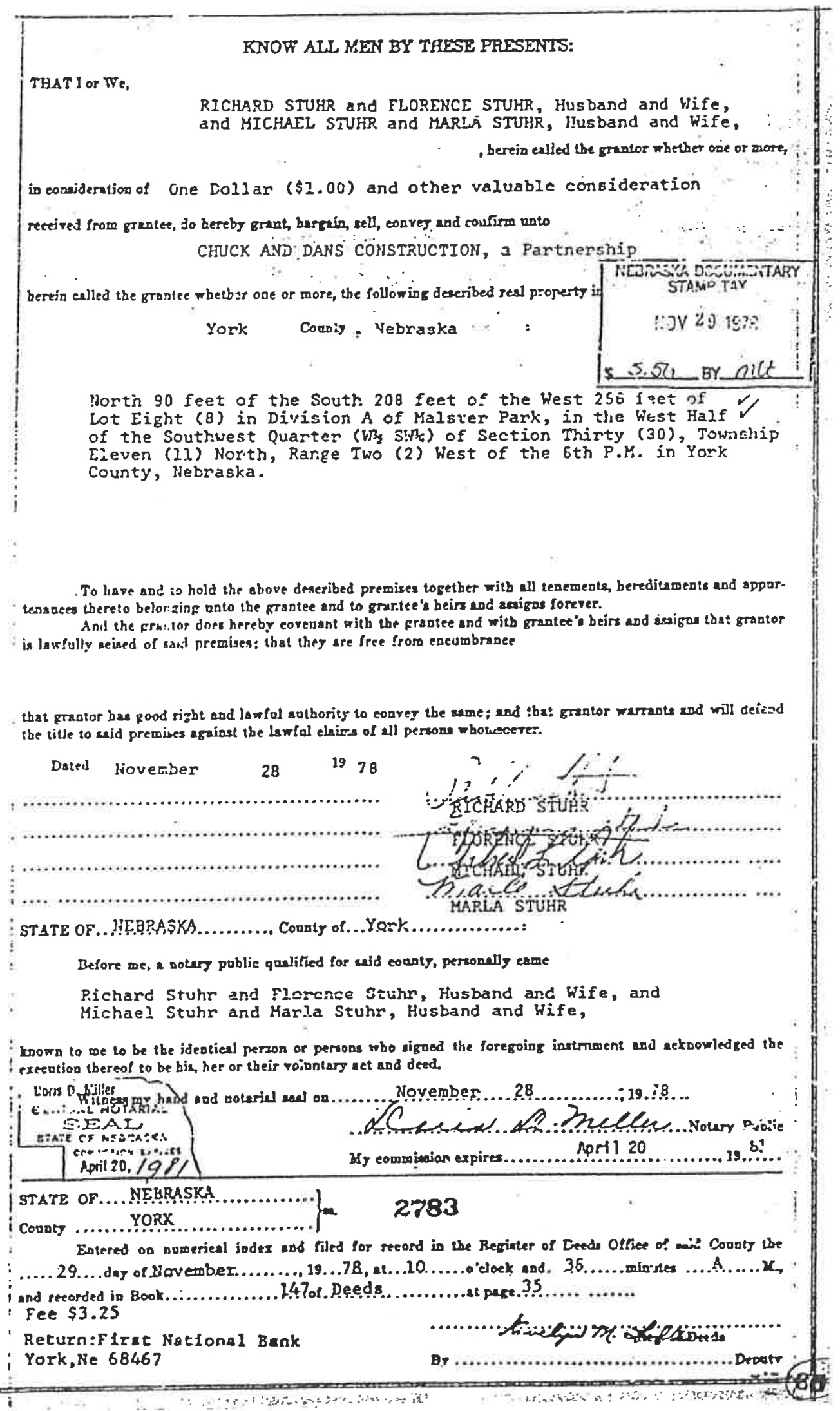




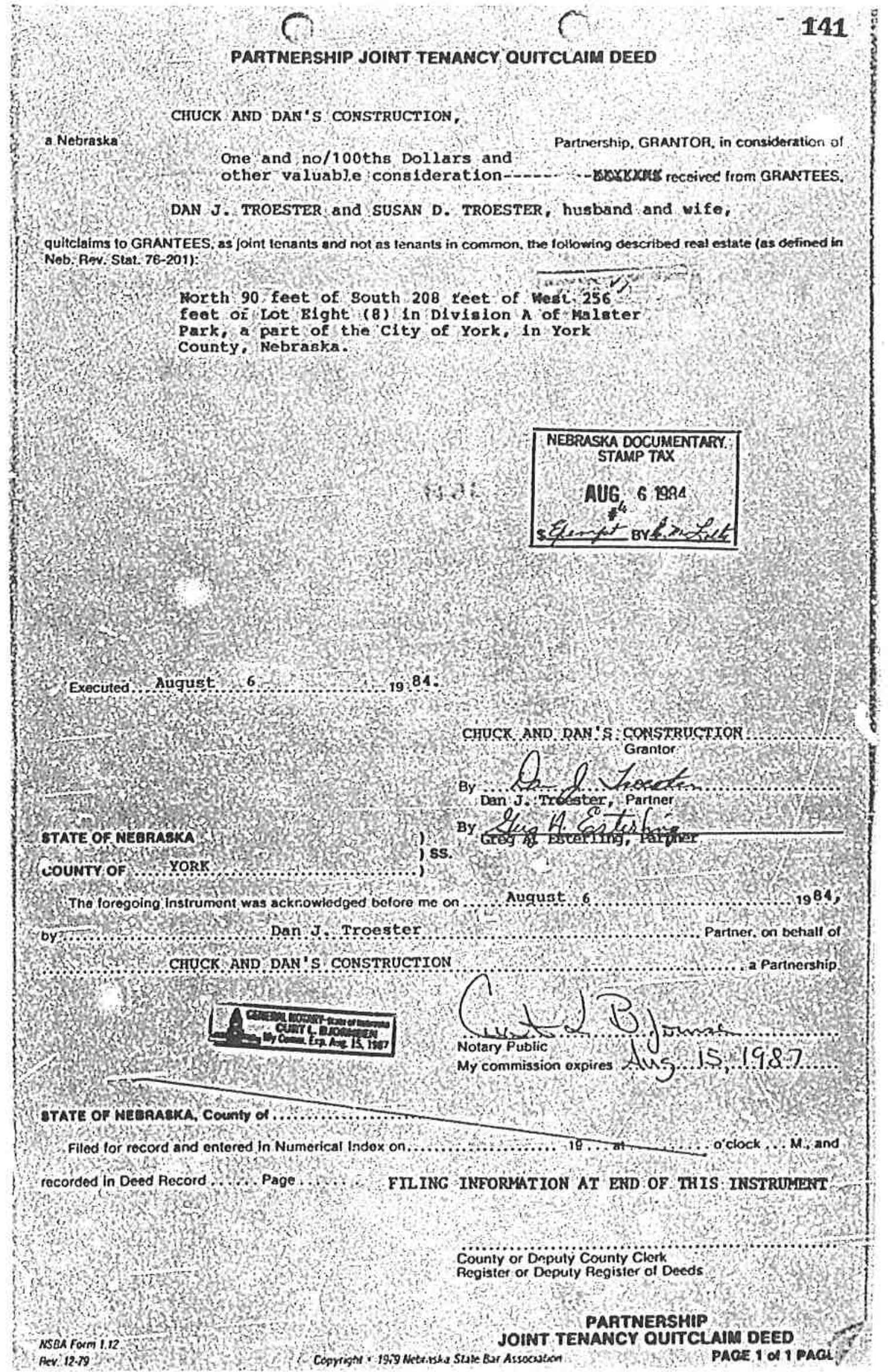




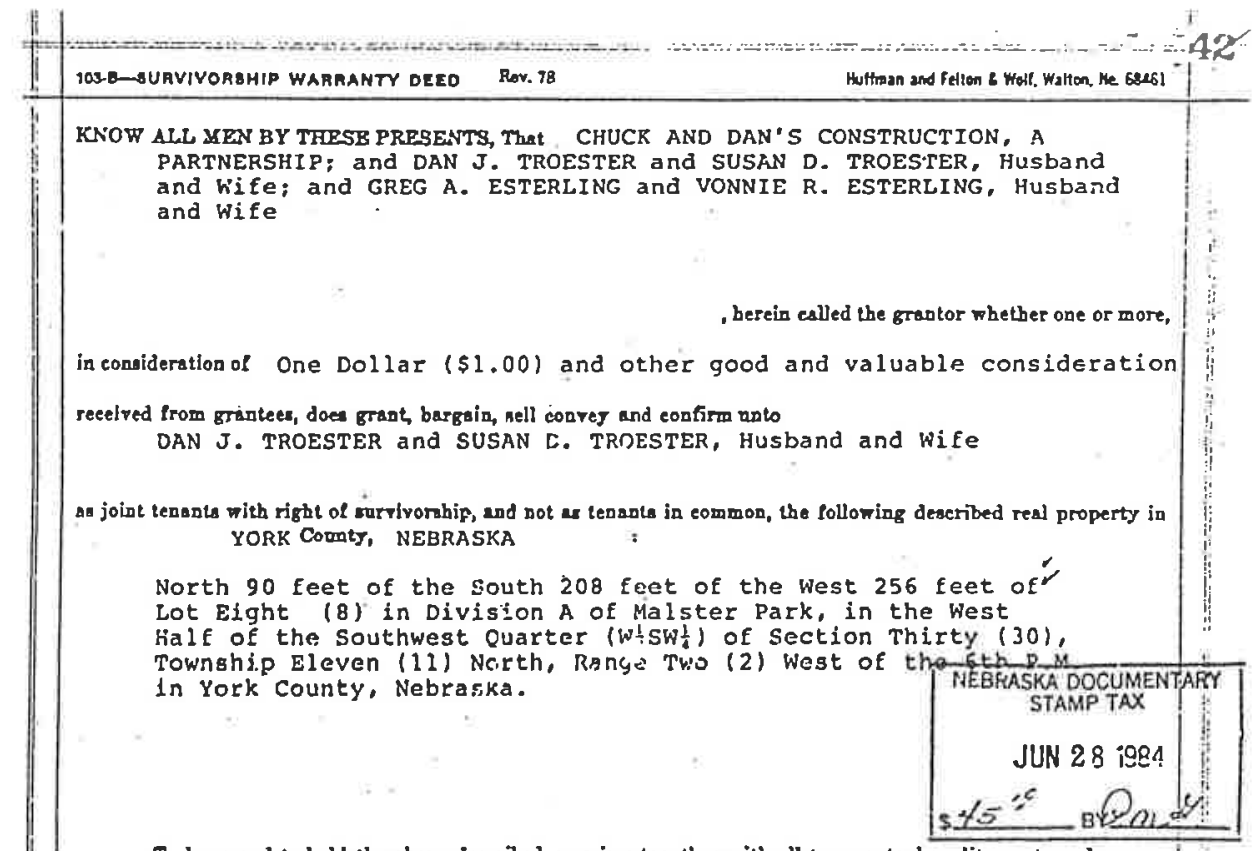

To bere and to hold the above deseribed premises togethe: with all tenements, hereditaments and appur: tenanees thereto belonging onto the grantees and to their assigns, or to the heirs and assigns of the sarviror of them forever.

And grantor does hereby corenant with the grantees and with their ansigns and with the heirs and assigns of the survivor of them thac grantor is lawfully seiced of asid premines; that thes are free from exenmbranee EXCEPT MORTGAGES OF RECORD

that grantor bas good right and lawful authority to convey the sume; and that grantor warrants and will defend the title to asid promises againat the fewfol eluims of all peraons whomeoter.

It is the intention of all partien hereto that in the event of the death of either of the grantees, the entire fee simple title to the resl eatate ahall vest in the surviving grantee.

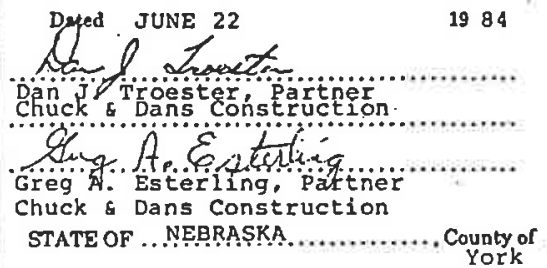

The luruguing instrument was acknowledged before is.

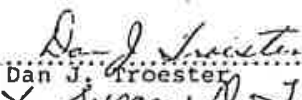

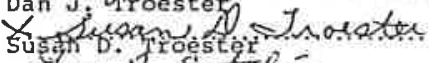

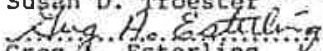
Greg $\alpha$. Esterifing Connsi R. nze. R....Esterling

...UnE. 22. 19. 84

by ....Pan. J...Troester and Greg A. Esterling. Partners of Chuck 8 Dan's

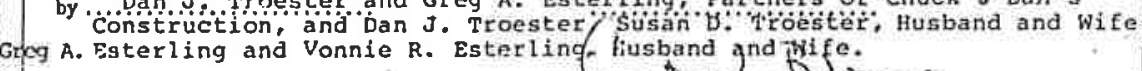
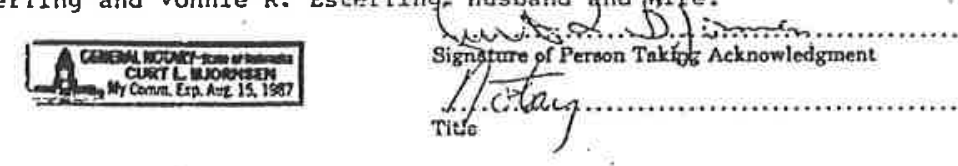

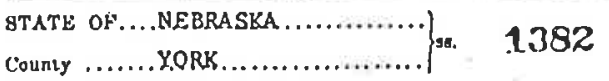

Entered on numerical index anc filed for record in tho Reginter of Deeda Otfice of asid County the

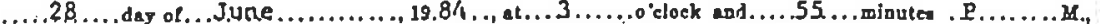

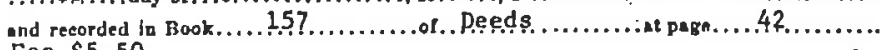
Fee $\$ 5.50$

Return:Firat National Bank York, Ne6 B467

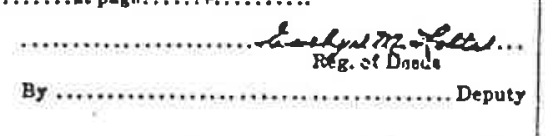

$$
\begin{aligned}
& \text { Cornhisiker Classics \& Dario Const } \\
& \text { Current ourers }
\end{aligned}
$$




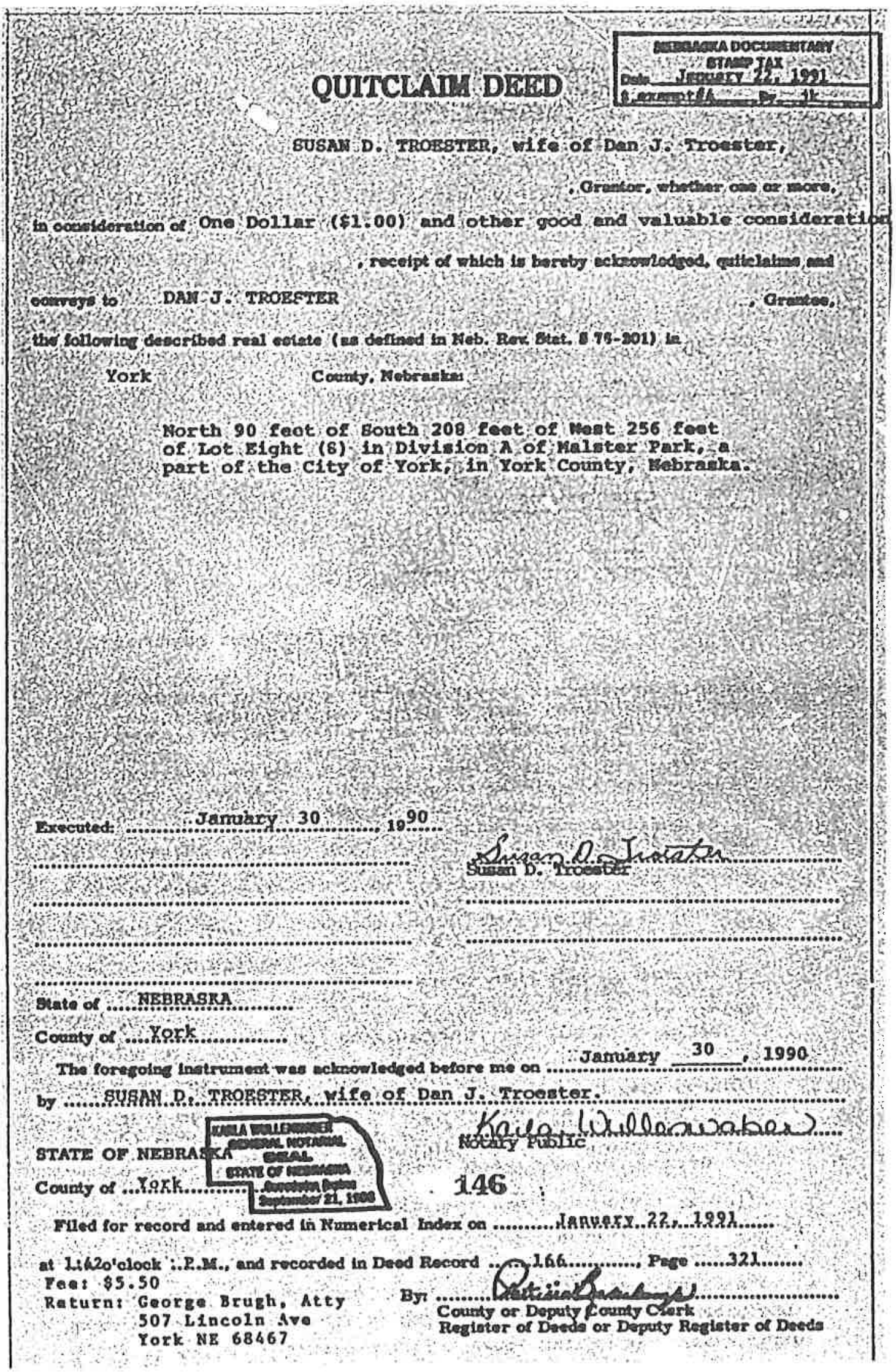


TILAT Ior We, Rtchard Stuhr and Florence Stuhr, husbarid and wife, and Micnzel Stuhr and Marle Stuhr, husband and wife,

, herein ealied the grantor whether oue or mort,

in consideration of One Dollar (\$1.0n) and Other haluable Consideration

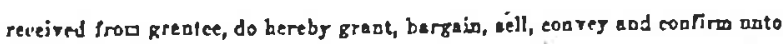

Chuck and Laa's Construction, a partnership

berein ealled the grantee whether ode or more, the following described real properts is

$$
\text { York County Nebraska : }
$$

North 88.5 feet of Hest 256 feet of South half (5k) of Lot Eight (8) in North 88.5 feet of Hest 256 reet of South half (Sh) of $\mathrm{A}$. Malster Park, a part of the City of York, in the Hest Half of the Southwest Quarter (Whs'isy) of Section Tnirty (30), Tomship Eleven (11) North. Range iwo (2) West of the 6th P.M. in York County, Nebraska

NEBRASKA DOCUMENTARY.
STAMP TAX
DEC 31 1979
II - BY B.T.

To have end to boild the above deseribed prexises together witb all tenements, hereditaments cad appor.

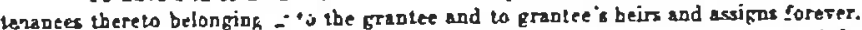

And the grantor does bereby corenant with the grantee aid with grantee's beis and arrigas that grantor is lastalls seised of an premises; that thes are free from exeambrace,

that graplor bas good rigbt and lawful euthority to conser the same; and that grantor warrants and will defend the litle to sajd premises aqainst the lawfel claims of alf persons whomsoerer.

Dated December $27 \quad 1979$

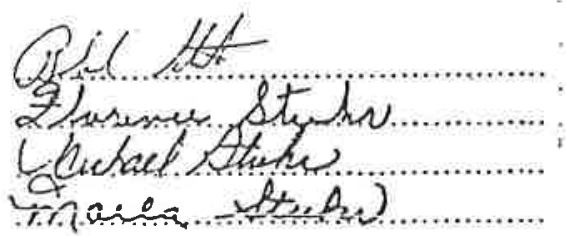

STATE OF Y.YBRASKA

County of

Y...rk

19.79..

The foregoing ingtrument was acknowledged before me

Decertorer. 27

by Richard Stuhr. and Elprence Stuhr, husband amo xife, and Michael Stuhr and

by Marla Stuhr, husband and rife,
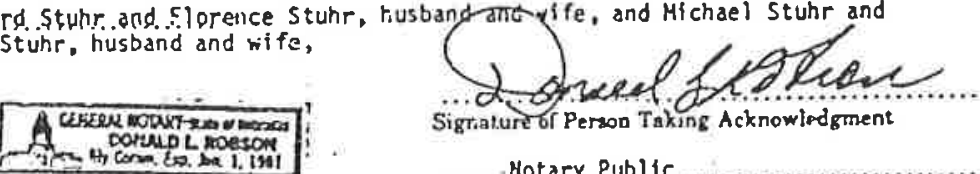

Sigrature of Peswo Taking Acknowlodgmen

Hy Conmission Expires Januar, 1, 1981

STATE OF...NEBRASKA

County ........ YORK.................

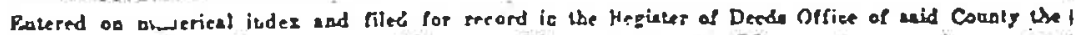

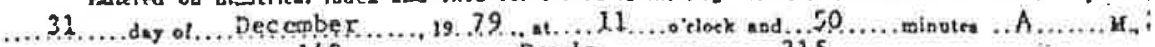

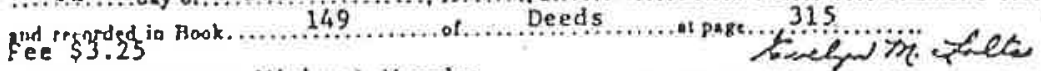

Return:Attorney M1chas 1 Murphy

lork, Ne 63467

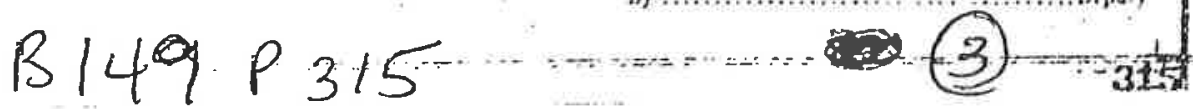




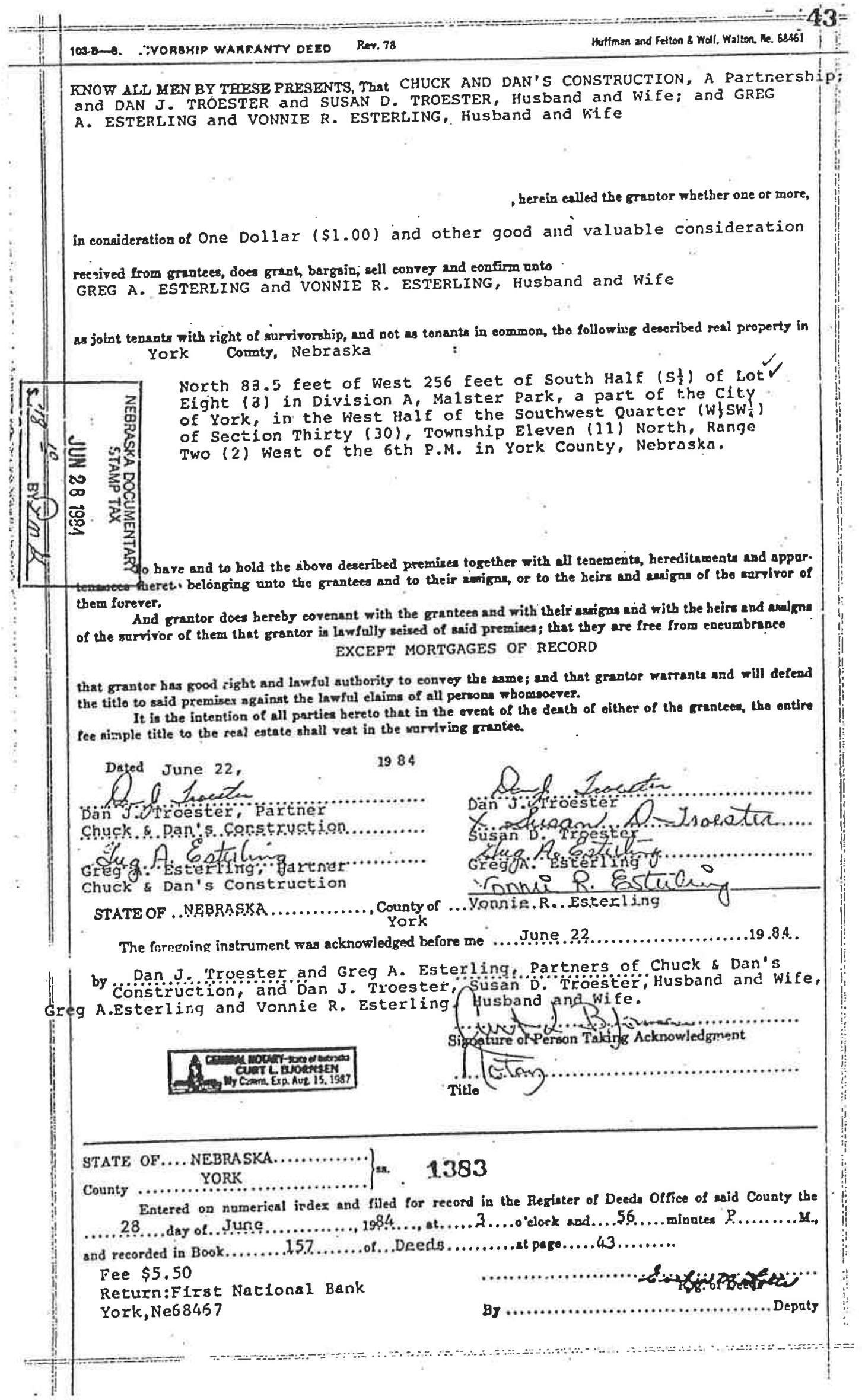


Notice is hereby given that a Contract for sale of Real Estate concerning the following described real estate, to-wit: North 88.5 feet of Weat 256 feet of South Half (St) of Lot $V$

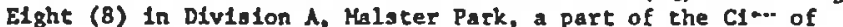
York, In York County, Nebraska.

was exacuted November 27 th, 1985 , by aid between 6 reg $\lambda$. Eaterling and Vonnle R. Baterling, hisaband and wife, Seller, and Gary M. Osentowskl and Debra A. Osentowski, husband and wife, Buyers. Buyers recelved possession of sald real estate on December 1 , 1985.

The Contract for 5ale of Real Estate together with abstract of title and warranty deed are beling held by list Trust company the escrow agent, until all terms of sa:d contract for sale of Real Estate are completed.

Dated this 27th day of November .2985.

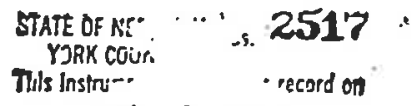

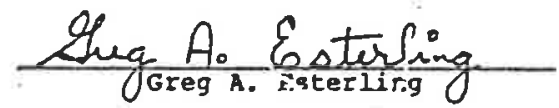
UGreg A. R.sterlir.g

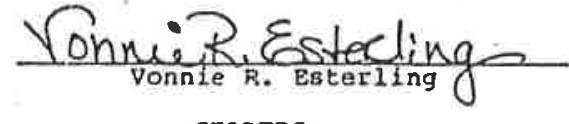

SELLERS

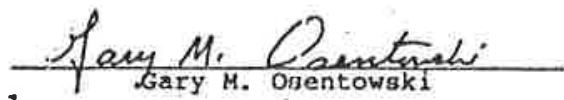

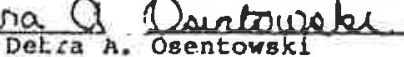
BUYRRS

STATE OP REBRASKA County of York 89.

The foregoing instrument was acknowledged before me on AOV. $2 Z$, 1985, by Greg A. Esteriling and Vonnie R. Esterilng, husband and wife.

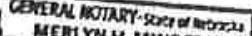 \\ MERTYN H. MINDEEATAN}

My comalssion explres

$$
\frac{\text { Herajh } 4 . \text { Hunamuan }}{\text { Notary Public }}
$$$$
2-13-1988 .
$$

STATE OF NEBRASRA

County of York

$$
\text { , } 88 .
$$

The foregolng instrument was acknowledged before on Noy. 27 , 1985, by Gary M. Osentewokf and Debra $\lambda$. osentowek1, husband and wife.

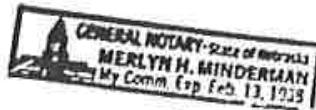

My comission explres<smiles>[Z10][14CH2][14CH2]</smiles>

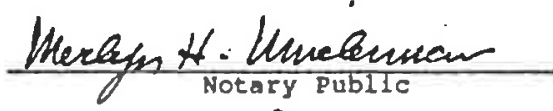
$2-13-1988$ 
Copies of Titles

Batterton Waterproofing 


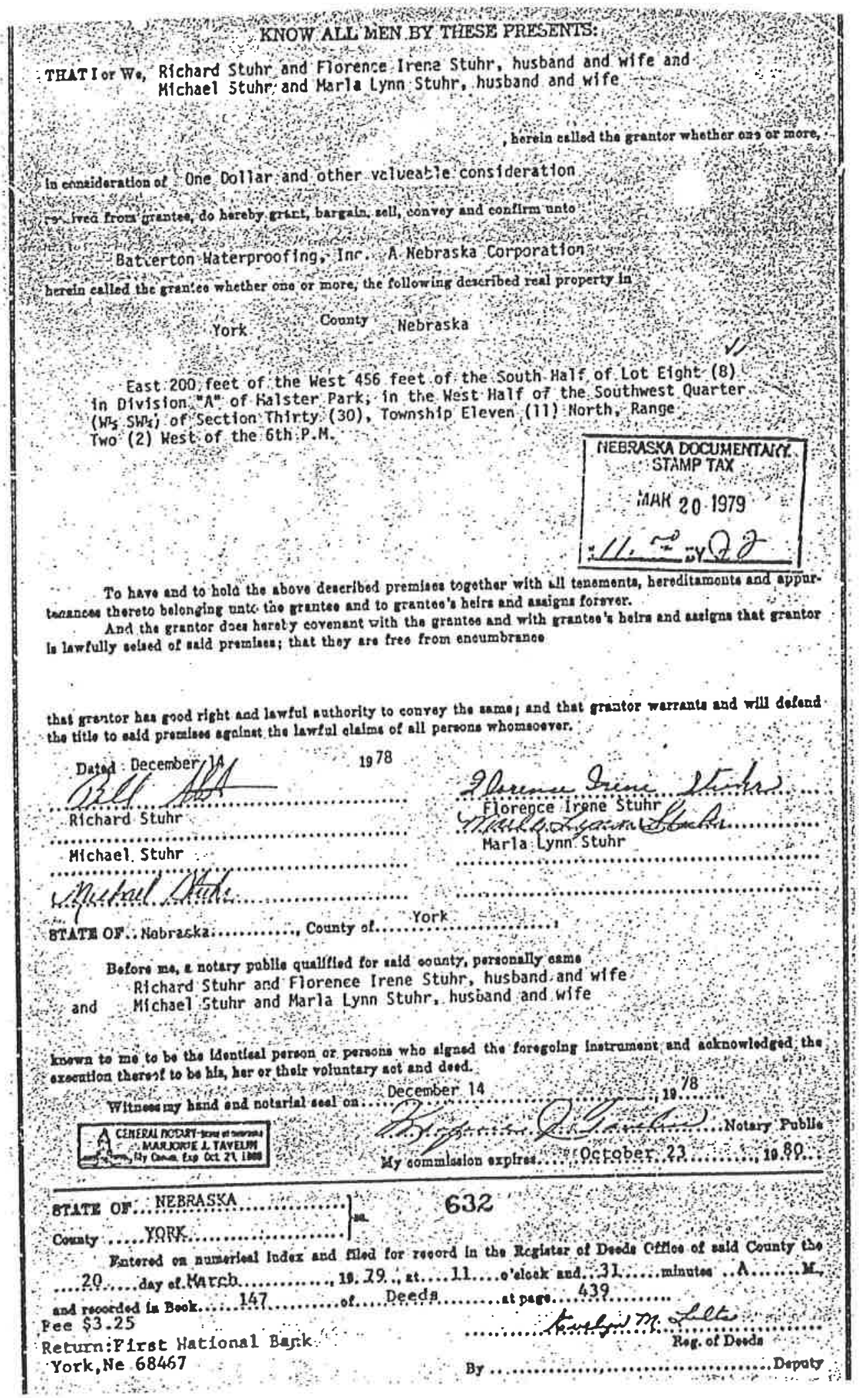




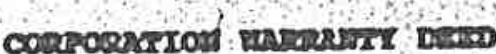

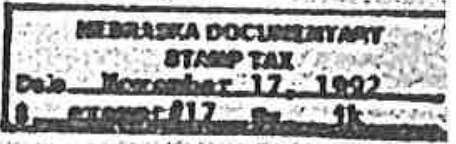

CL, IUC.., a corporation organised and exinting undar tha lats of tho state of Hebrasich, Exantor, In conslderat lon of one Dollar

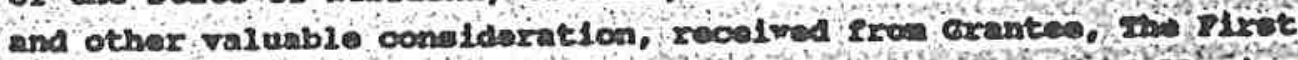

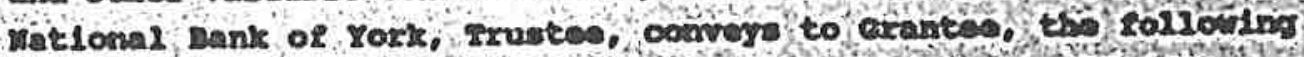

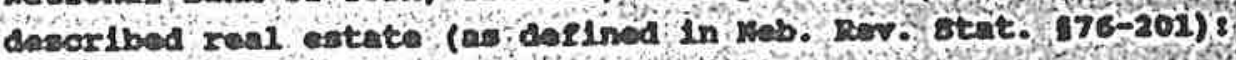

Eant 200 soot of tho west 456 reot of tho south Bals.

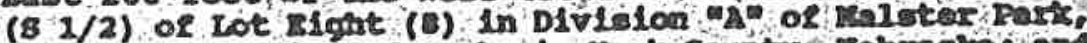
a part of the cley of York, in. York county, Lobraskic s and

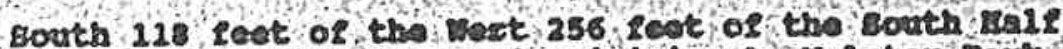
(8 $1 / 2)$ of lot Elght (8) In Division A Malster Pert, a part of the clty of York, In rork county obralia.

Grantor covenants vith Grantes that Grantor:

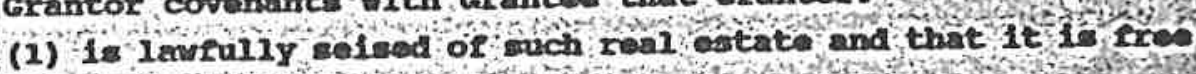
sroe encumbrances:

(2) has legal power and I a fui authorlty to comver the ganes and

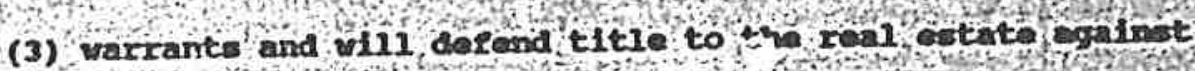
the laviul clailes of all persons.

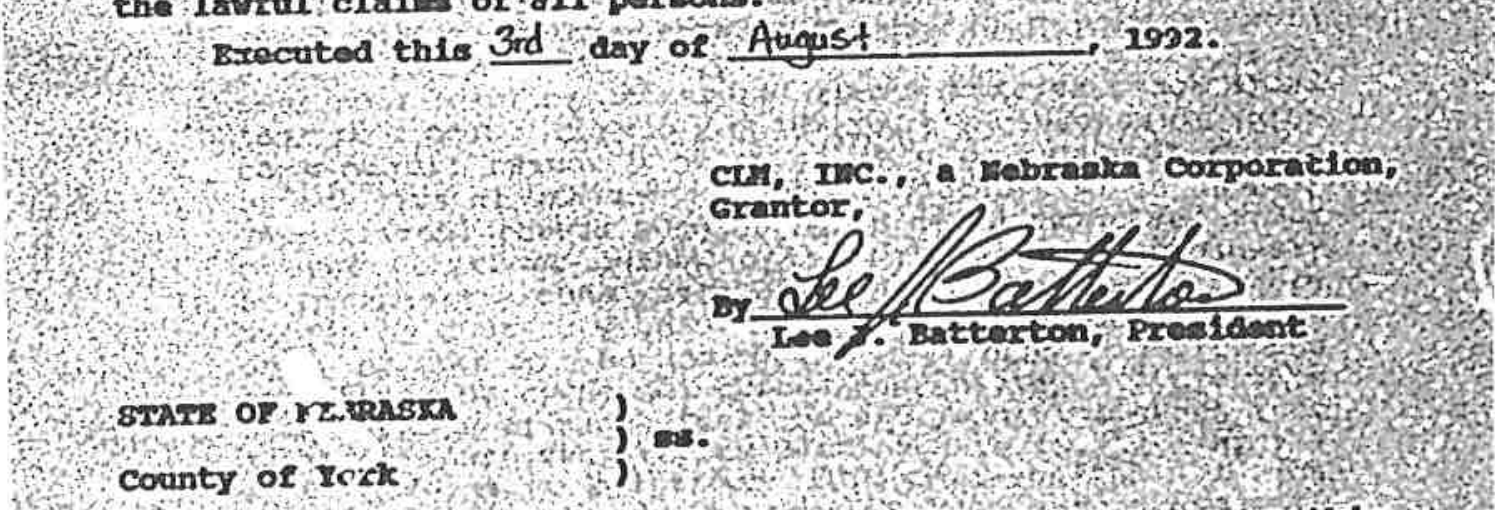
county of Iork.

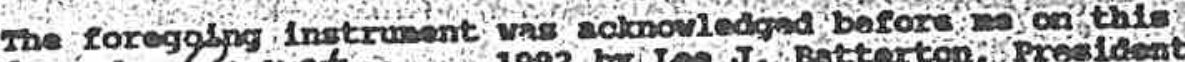

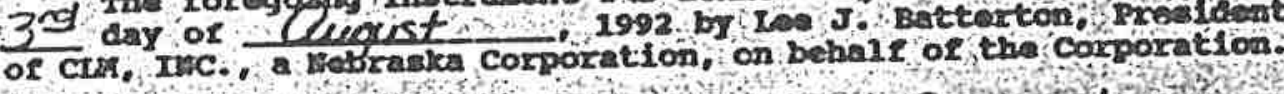
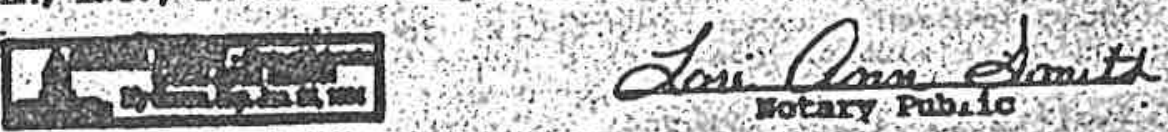

ny conlsesion oxplress $4 / 25 / 94$

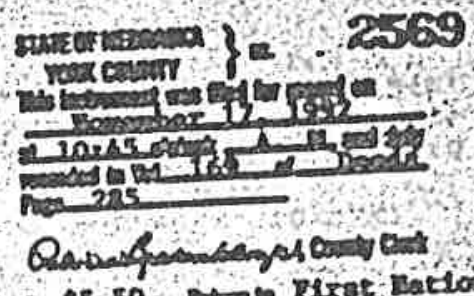

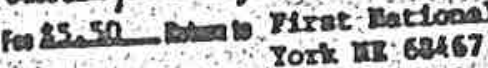


Copies of Titles

Scoular Grain North 


\section{Warranty Deed Record}

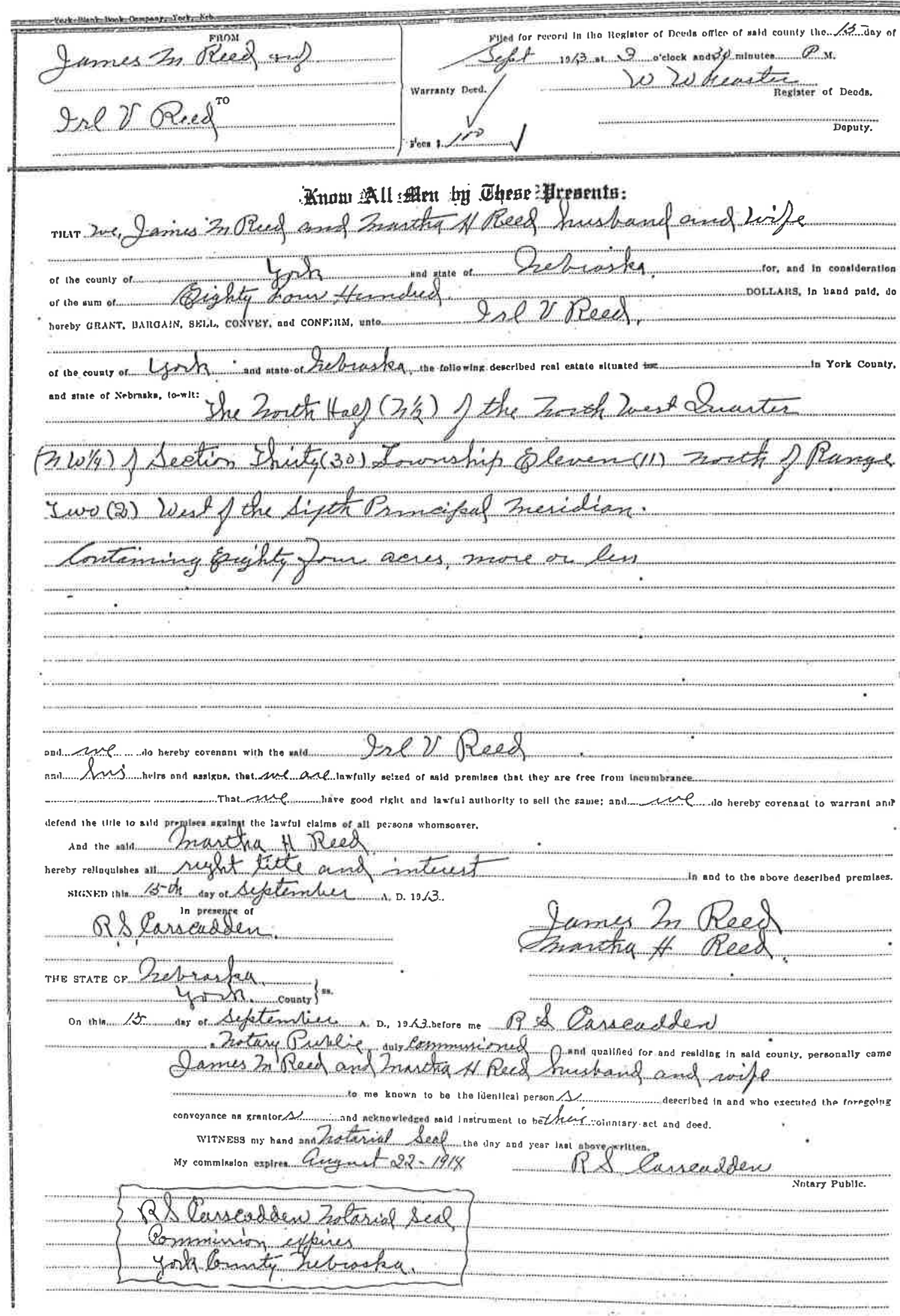




\section{DEED RECORD}




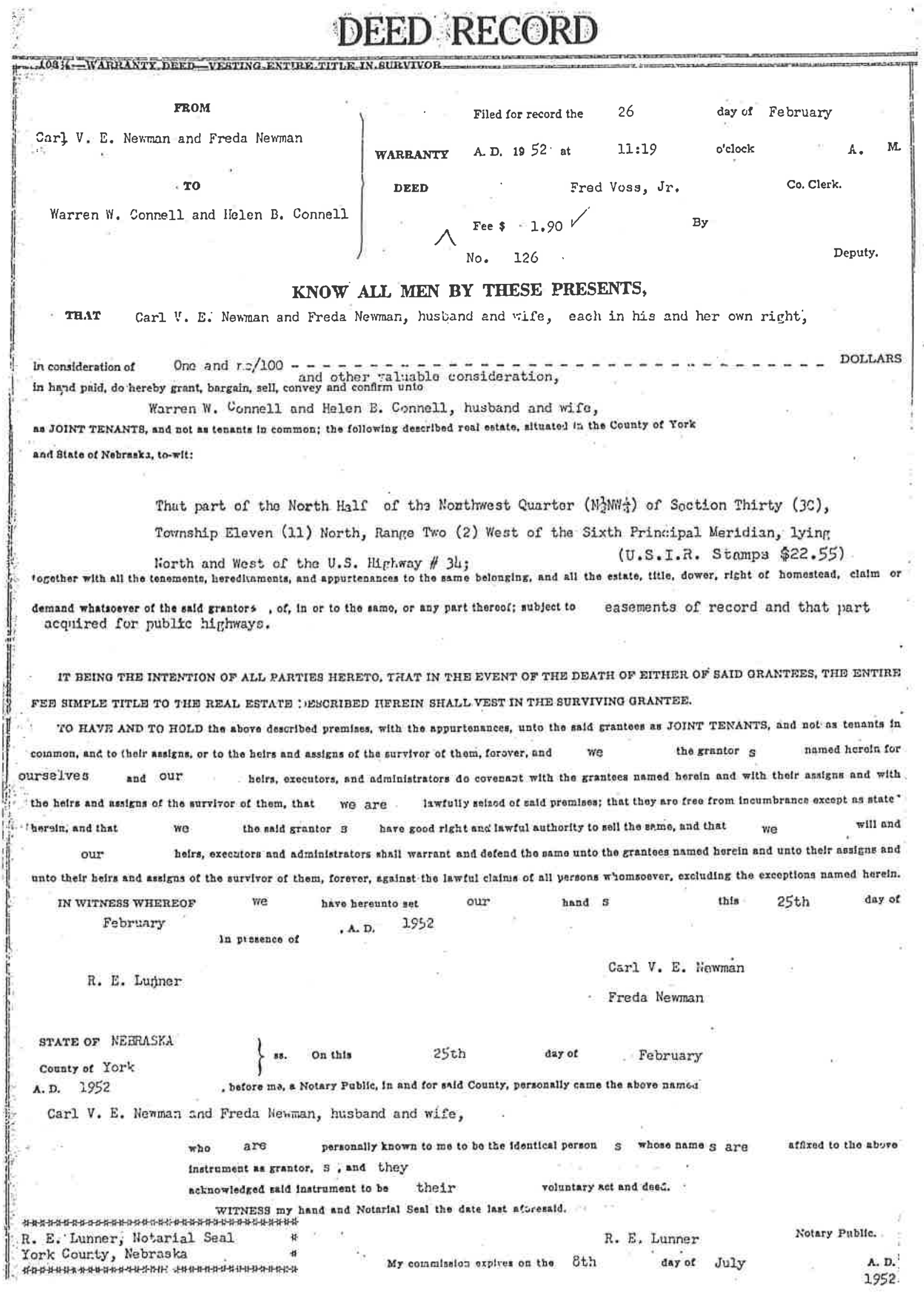




\section{DEED RECORD}

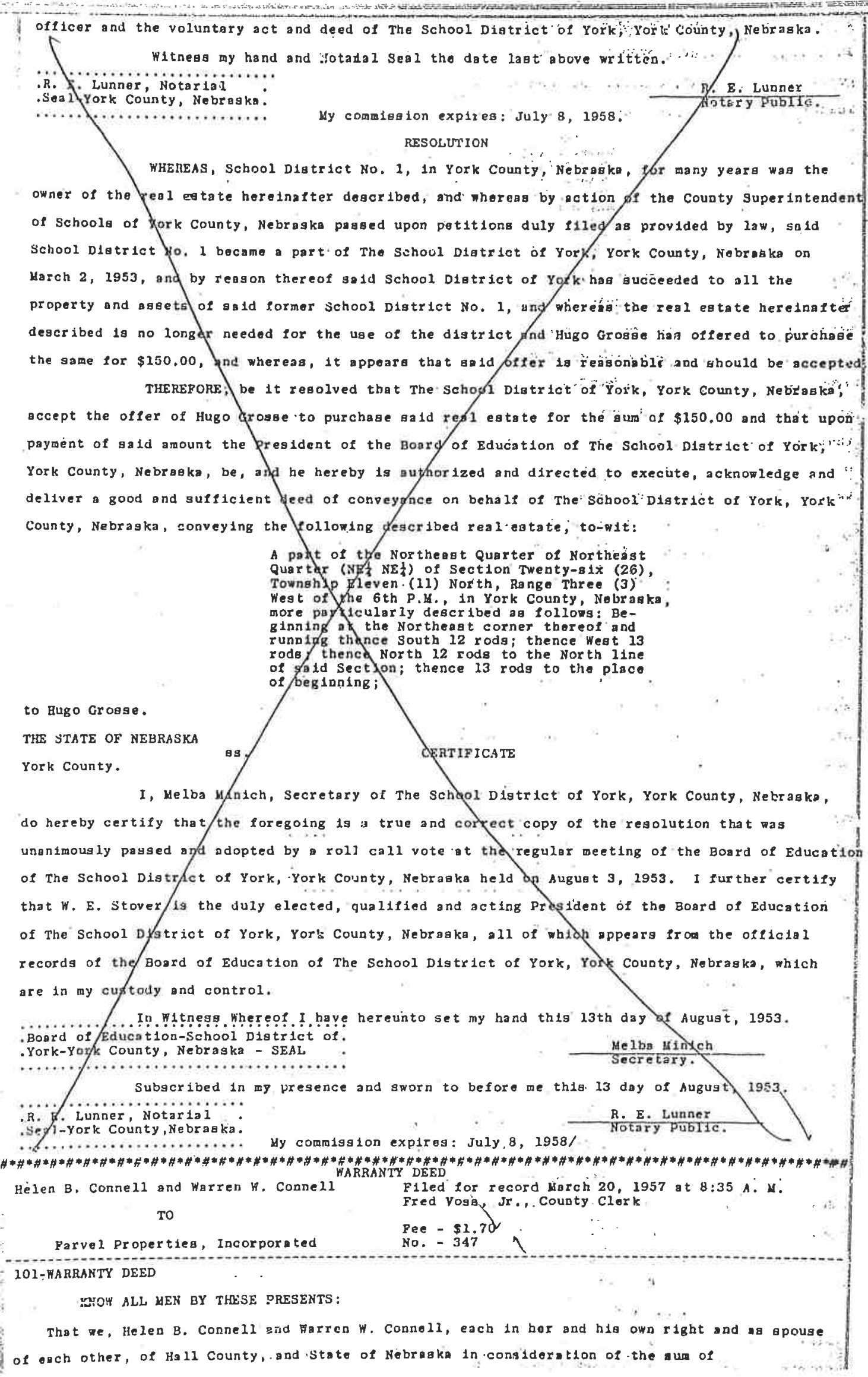




\section{DEED RECCRD}

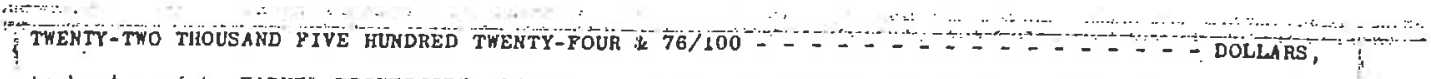

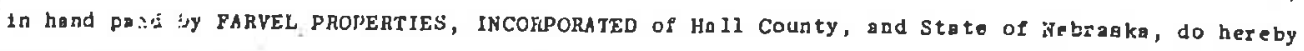
grant, bagkatn, gell, convey, and confirm unto the suid FARVEL PROPERTIEs, INCORPORATED the lollowing delocribed premigeg, altuated in the county of York and state. of Nebragka to vit:

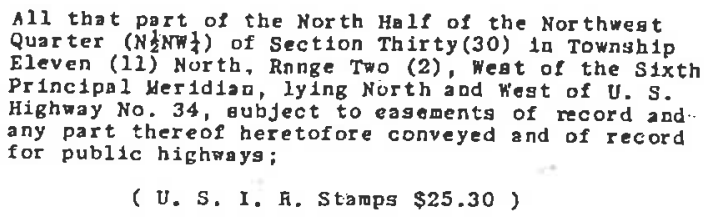

rogether with all the tenements, hereditaments and appurtenances to the same belonglng, and all the Estate, Right, Titie, Interest, Clajm or Demand whatsoever Including Dower, Curtesy and Honestead fights of the said grantors of, is, or to the same, or any par: thereof.

TO HAVE AND TO HOLD the above described premisea, with the appurtenancea, unto the said MARVEL PROPERTIES, INCORPORATED and to its succesgors and osigng forever. And we hereby covenat i 1 th the said PARVEL pROPERTIES, INCORPORATED that we hold sald premises by good and periect title; that we have good $r i g h t$ and lawful authority to aell and convey same, that they are lree and clear of all lleng and Incumbrances whatgoever, exceptiag mortgages now of record; And ve covenant to' morrant aud defent the eald premises agalngt the lawlul clatms of all persong whomadever.

Signed this 15 th day of Harch $A . D ., 1957$.

In presence of

Helen B. Connell

Herlate F. Hajer

Warren W. Connell

THE STATE OF NEBRASKA

MALL County

\} s5.

On this 19th day of Harch 1957 before me, Herbert $F$. Hayer a Notary public within and for satd County, pergonaliy came Helen

$B$. Coonell and warren $W$. Conne12, each in her and his own right and as apouse of each other, to me known to be the Identical pergon whose names are affixed to the above instrument ag grantora, and severally acknowledged the execution of the same to be their voluntary act and deed for the purposea therein expreased.

IN WITNESS WHEREOF I have hereunto gubger lbed my name and affixed my official seal at Grand Island on the w te last above written.

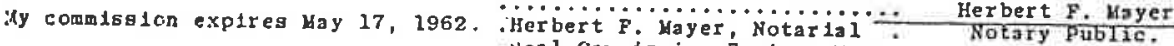

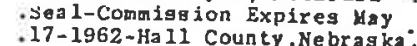
, Nebraska

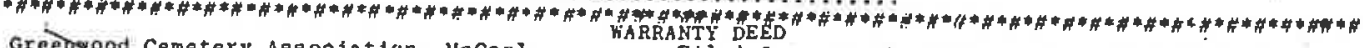
Greenrood Cemetery Association, HcCool Filed for record March 22, 1957 at 1:20 P. M.<smiles></smiles>
D. G. Dratth Fee - $\$ 1.70$ No. - 388

WARRANTY DEED-GREENWOOD GEHETERY ASSOCIATION-MCCOOI.

KNOW ALL MEN BY THESE PRESENTS:

That THE GREENWOOD CEHETERY ASSOCIATION kCCOOl, of the Councy. of York, State of Nebraspo, In

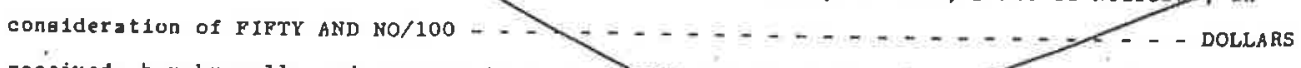
recivived, hereby sells and conveys to D. G. Srrye, Lot 65 in Division, Greenwood remetery McCool, 10 York County, Nebraska, and covenants to varyant and defend the title thereto, to the sald D. G. SKITH and his helrs and agsigns, agalnst the lowxul clolus of all persong phomsoever, However, subject to the by-lows, ruleg and regulationg of sald Cetetery Asgociation. Including perpetual upkep of usid lot. Slgned 5 th dag of December 1951

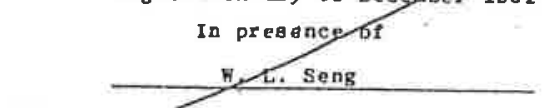
STATE UF NEERASKA ? County of York )

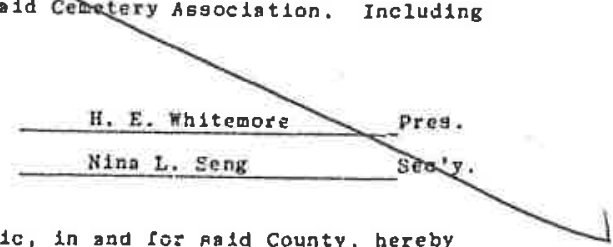


XKOW ALL MEN BY THERR PREBLNTS, TIJAT FARVEL PROPERTIES, IMCORPORATED

- corporalion organized end eximting under and by virtue of the lawe of the gute of Nelir uska in cunsileration of Ten Thousand Dollars $(\$ 10,000,00) \ldots$ received from prantesin, duex grum, hatpain, sell ronvey and coutitm unto

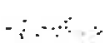

DEAN SACK

heaein eafled the granter whetlier num or more, tlie following deseribed real property in

$$
\text { York (inuiy. Nebraska : }
$$

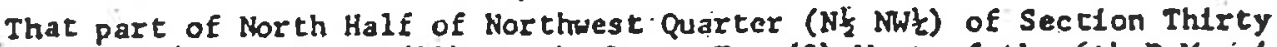
(30), Towriship Eleven (11) North, Range. Two (2) West of the 6th P.M.; In York County, Nebraska, lylng North and West of U.S: KLghway 434 , EXCEPTING the north 363 feet of the west 363 feet AND a tract described as follows: Beginning at a point on the south line of sald Northwest Querter of the Northwest Quarter of sald Section 30 whare the same 1a Intersected by the wost right-of-way line of U.S. Highway Nos. 81 and 34 , and running chence westerly along the south line of suid Northwest Quarter of the Northver Quarter a digtance of 200 feet; thence northerly on a line-parallel to the eazt line of said Northwest Quarter of the Northweat Quarter distance of 410 feet; thence easterly and parallel to the sald South line of ald Northwegt Quarter of Northwest Quarter to the weat of right-of-way IIne of syid U.S. HIghways hos, 81 and 34 and running thence along the west; right-of-way live southeaslerly on a curve to the point of beginning.

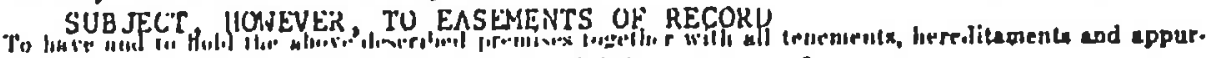

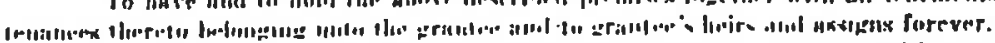

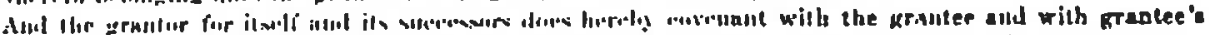

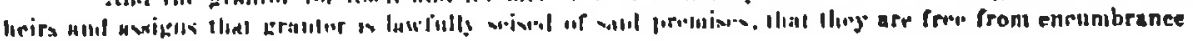

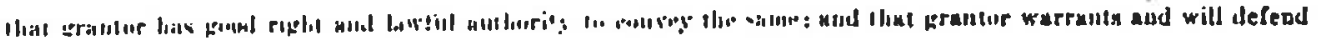

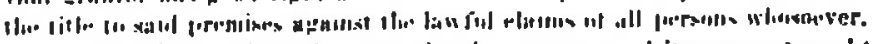

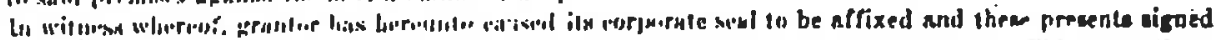

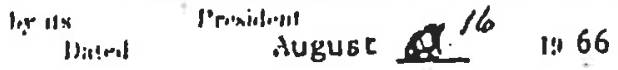

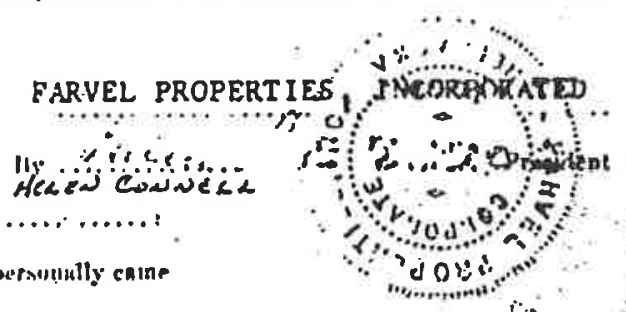

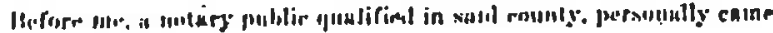

I'reuldétel of

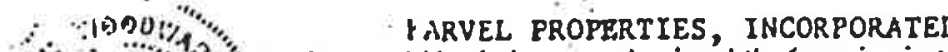

a corporation k.mp

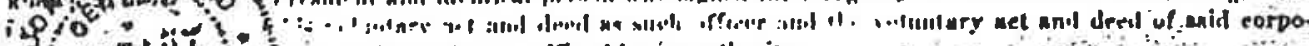

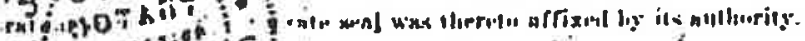

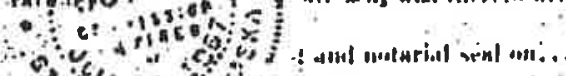
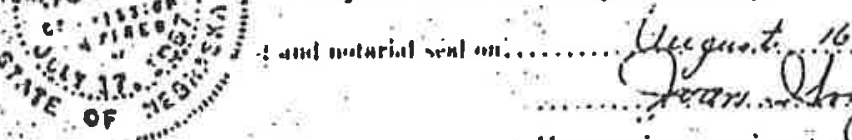

.

$\therefore 19.66$

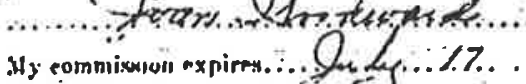

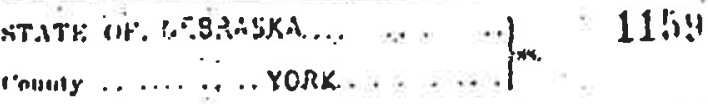

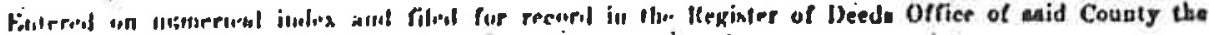

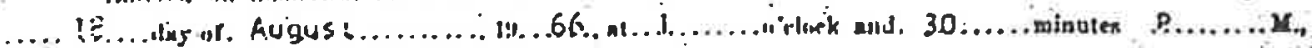

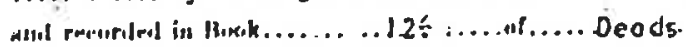

ipe: $1 .-5$

-wnive- ibet. Co.

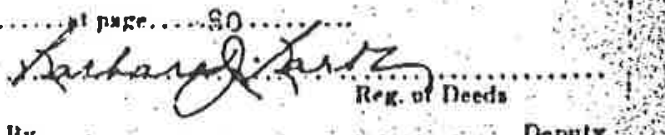


WARRANTY DEED

Dean Sack and Flosisie Sack, husband and wife i hrein ralled the grator whothar ore or mors,

in conelderation of One dollar and othor viluable conulderation recolrod trom smatos, doen grant, bargain, sell; ennvey and confiren unto

York State Bank, Trustee

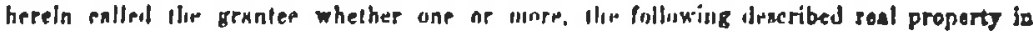

York.

Counly, Siebruks: That part of North Half of Northwent Quarter (N 1/2 NW 1/4) of Section Thirty (30), Townuhip Eleven (11) North, Range 'Two' (2) Weot of the 6th P.M., in York County, Nebraska, lying North and Went of U.S. Highway 34, EXCEPTING the north 363 feet of the west 363 feet AND a tract deicribed a follows: Beginning at a point on the south line of sald Northwent Quarter of the Nortbwent Quarter of said Section 30 where the same is intersected by the weot rlgbtof-way line of U.S. Highway Nos. 81 and 34, and running thence westerly along the couth line of said Northwest Quarter of the Northweot Quarter a distance of 200 feet: thence northerly on a line parallel to the east line of sajd Northweet Quarter of the Northweot Quarter a distance of 110 feet; thence easterly and parallel to the sald South llne of sald NWill of Nivlit to the west right-ol-way line of said U. S. Highways Nos. 81 and 34 and running thence along the west right-of-way line outheseter on a curve to the point of beginning. SUBJECT HOWEVER TO EASEMENTS OF RECOR

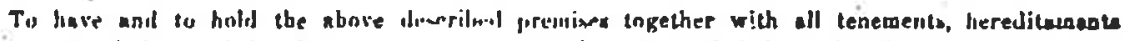

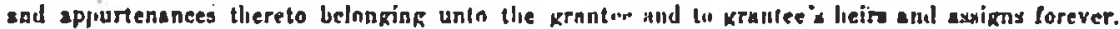

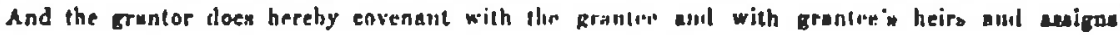

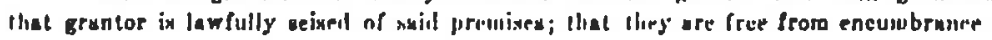

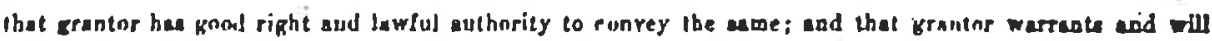
defend the title to maif premiges agsinat the lawful claius of all perwons whomecrer.

Datert Auguet $27 \quad 19.66$
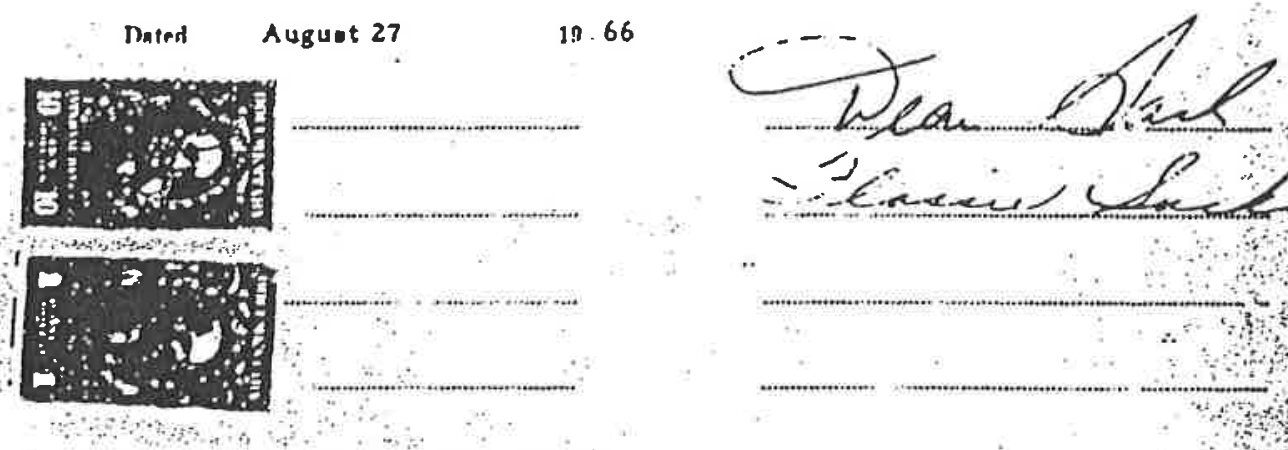

NTATE OF NESKASKA, Counts of

York

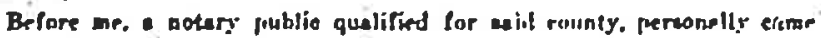

Deañ Sack and Flosile Sack, husband and wife

(1) $v_{\theta_{0}}$

3 तथ

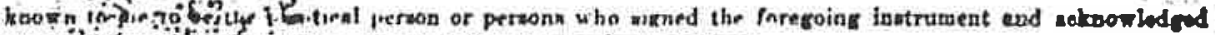

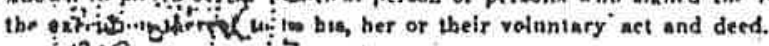

(1) "

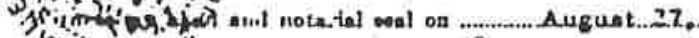

rn. vous

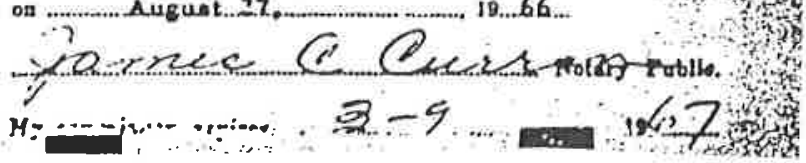




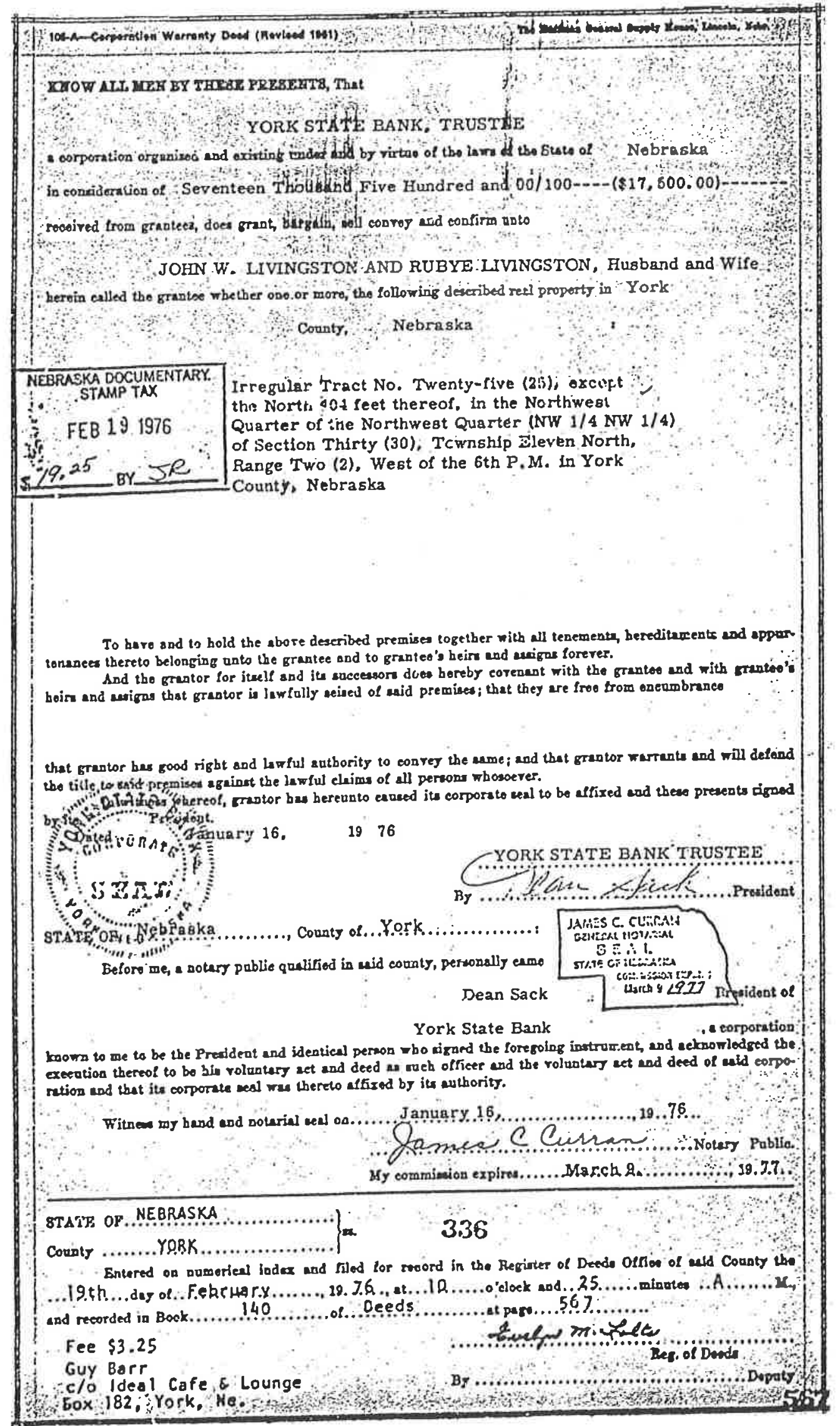


ENOW ALL MEN BY THESE PRESENTS. That John W. Livingston and Rubye

Lfvingston, husband and wife, each in his and her own righi-

, herein ealled the grantor whether one or more,

in consideration of One Dollar $(\$ 1.00)$ and other valuable consideration

receired trom gruatees, does grant, bargain, nell esonvey and confirm anto

MELVIN L. SMOCK and DEBRA SHOCK

as join: tenants with right of surrirorsaip, and aot as tenlants in common, the tollowing described real property in

$$
\text { York Cousty, Nebraska : }
$$

Irregular Tract No. Twenty-Five (25), except

the North 404 Feet chereof, in the Northwest

Quarter of the Northwest Quarter (NWt. NHt) of

Section Thlrty (30), Townshlp Eleven (11)

North, Range Two (2), West of the 6th P.M.,

in York County. Nebraska.

To have and to bold the above described premises togetber with all tnnements, hereditanents and appur. tenances thereto belonging unts the grantees and to their oxsigns, or to the heirs and assigns of the surviror of them forever.

And grantor does heraby covenunt with the grnateess and with their asaigna and with the lseirs and asaigna

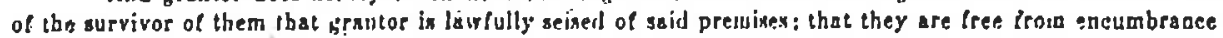

that prantor has good right and lawful authoricy to courey the same; sud that grantor warrants and will defend the title to said premises against the lawful slaims of all persons whomsoeres.

It is the intention of al! parties hereto that in the event of the death of either of the krsciees, the entire fee aimple title to the stal eytate shall rest In the gurviving grantue.

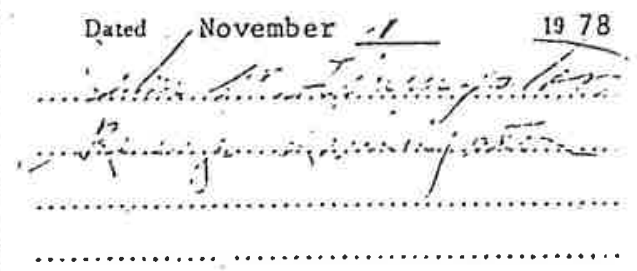

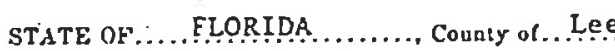

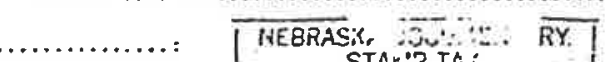

Before ze, a notary publie quelified for sxid covoty. personally came John W. LIvingston and Rubye Livingston

กิบบ 81978

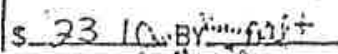

knowa to me to be the identical person or persons who signed the toregoing instrument and foknocivicalged the execution therenl wo be his, her or their voluntury act and deed.

Witness wy hand and notarial aeal on. November.
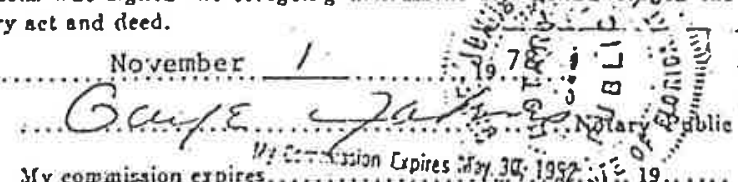

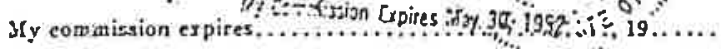

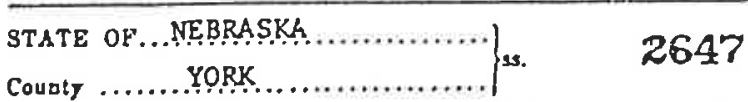

Entered ion numericul indez and filed for record in the Register of Deerls otfice of waid County the

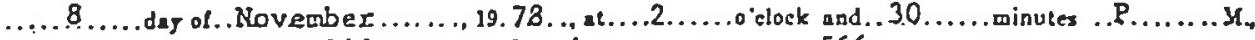

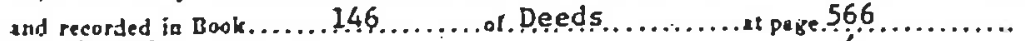

Eee $\hat{\imath} 3.25$

Return:Lunner Abstract, York, Ne 68457

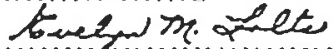

Rr...oi Deeds

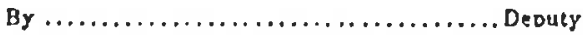




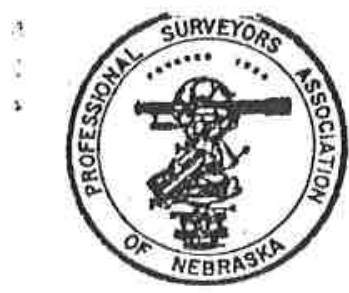

\author{
SURVEY RECORD \\ York County, Nebraska \\ Rex Heiden L.5. 361 \\ RT. 1 \\ Waco, Nebraska 68460
}

Survey of Irregular Tracts No. 29 and 30, being South of the North 404.0 feet of I.T 25 in the Northwest Quarter of the Northwest puarter

Section 30 TOWNSHIP II NORTH, RANGE 2 WEST of the 6 th PRINCIPLE MERTDIAN IN NEBRASKA

Date, Dec. 24,2981

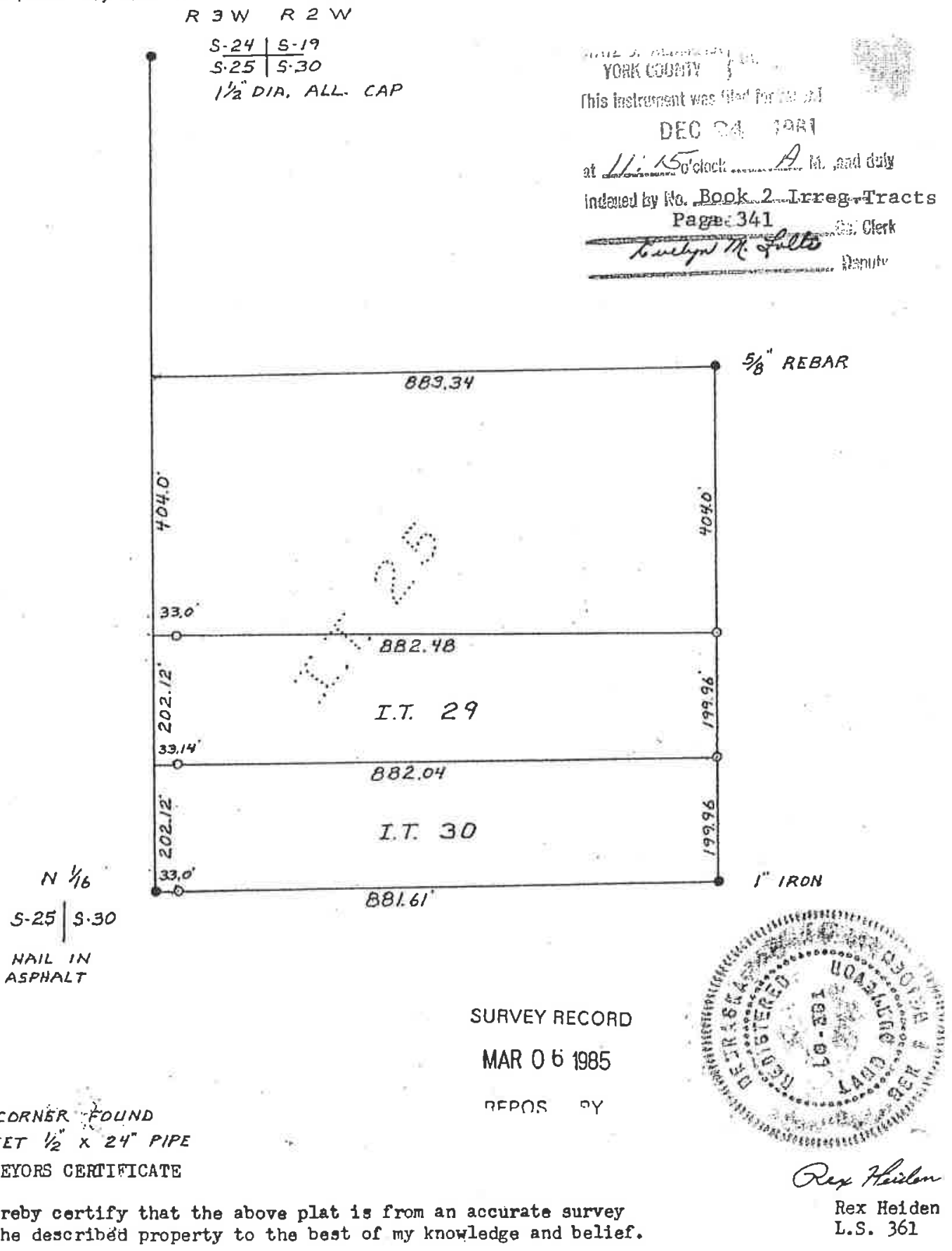



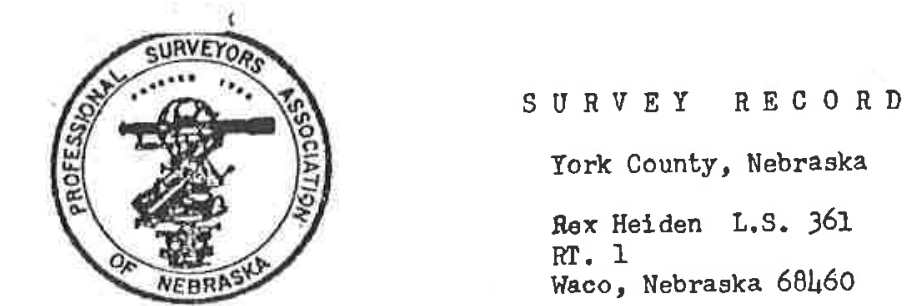

Survery of Irregular Tracts No. $29 \& 30$

Section 30 TOWNSHIP 11 NORTH, RANGE 2 WEST of the $6^{\text {th }}$ PRINCIPLE MERTDIAN IN NEBRASKA Date Dec. 24, 1982
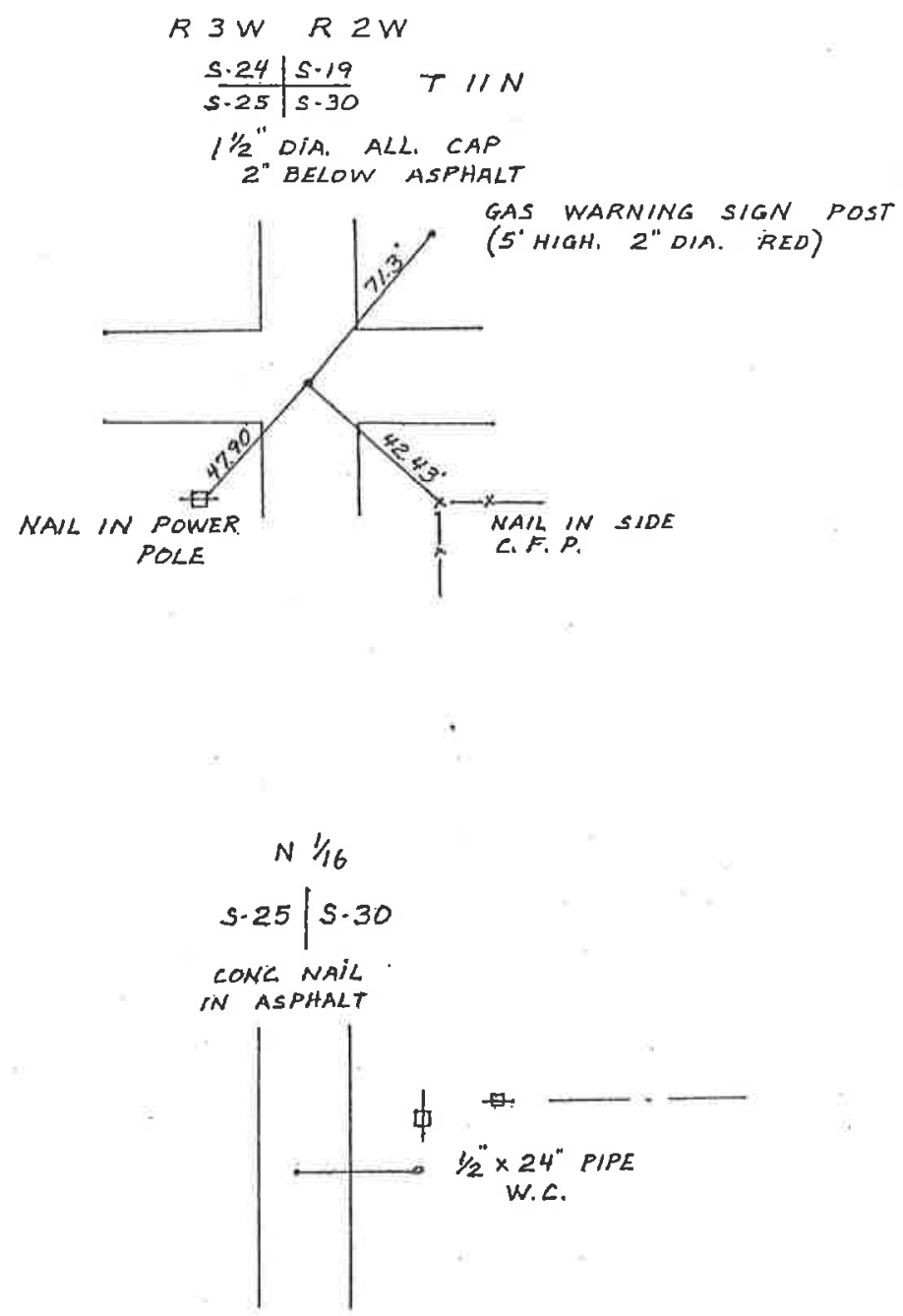

\section{SURVEY RECOTD}

MAR $O$ O 1985

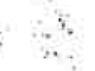

nEPOS SY

I hereby certify that the above plat is from an accurate survey of the described property to the best of my knowledge and bellef.

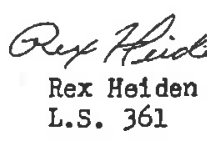




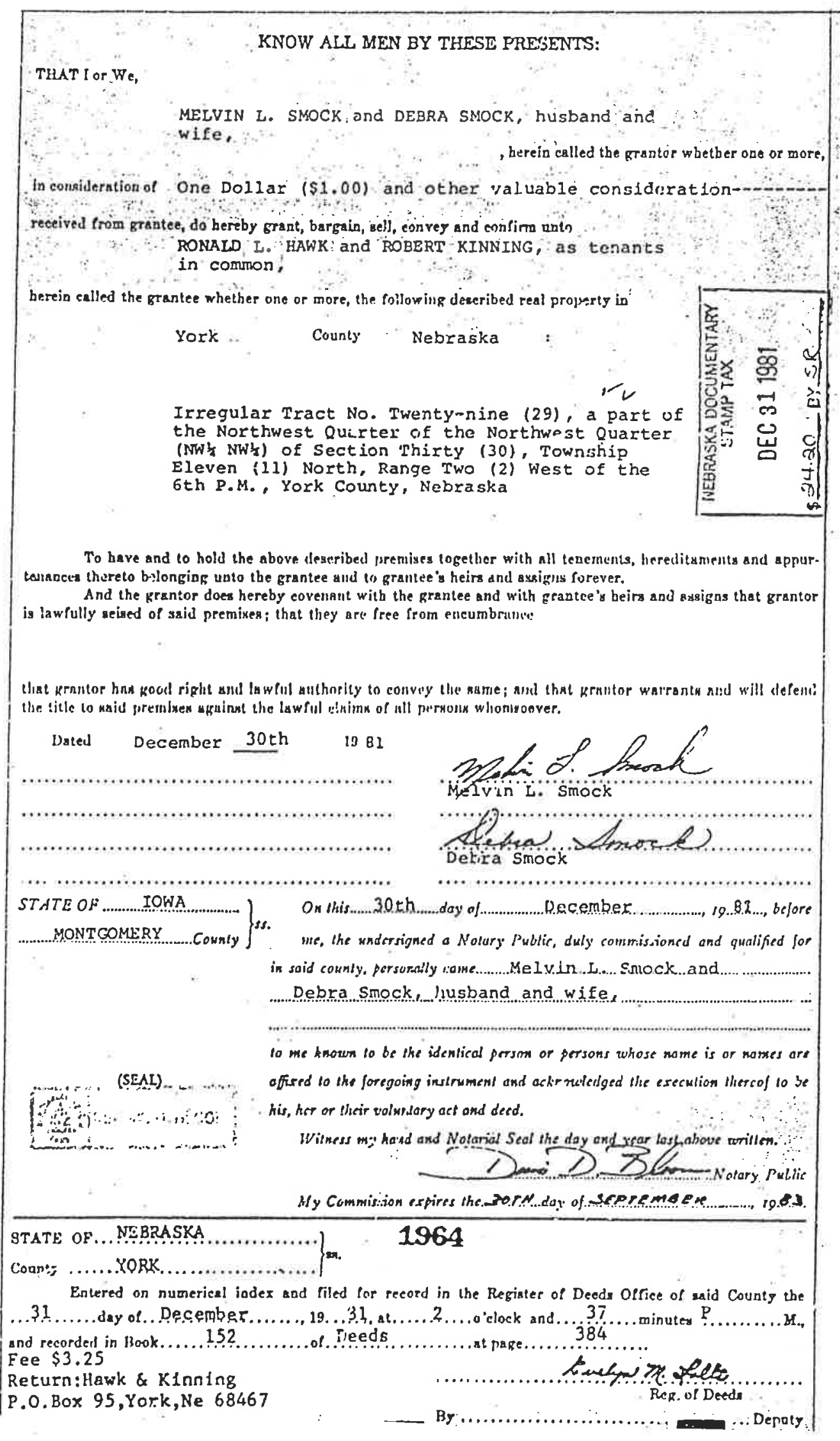




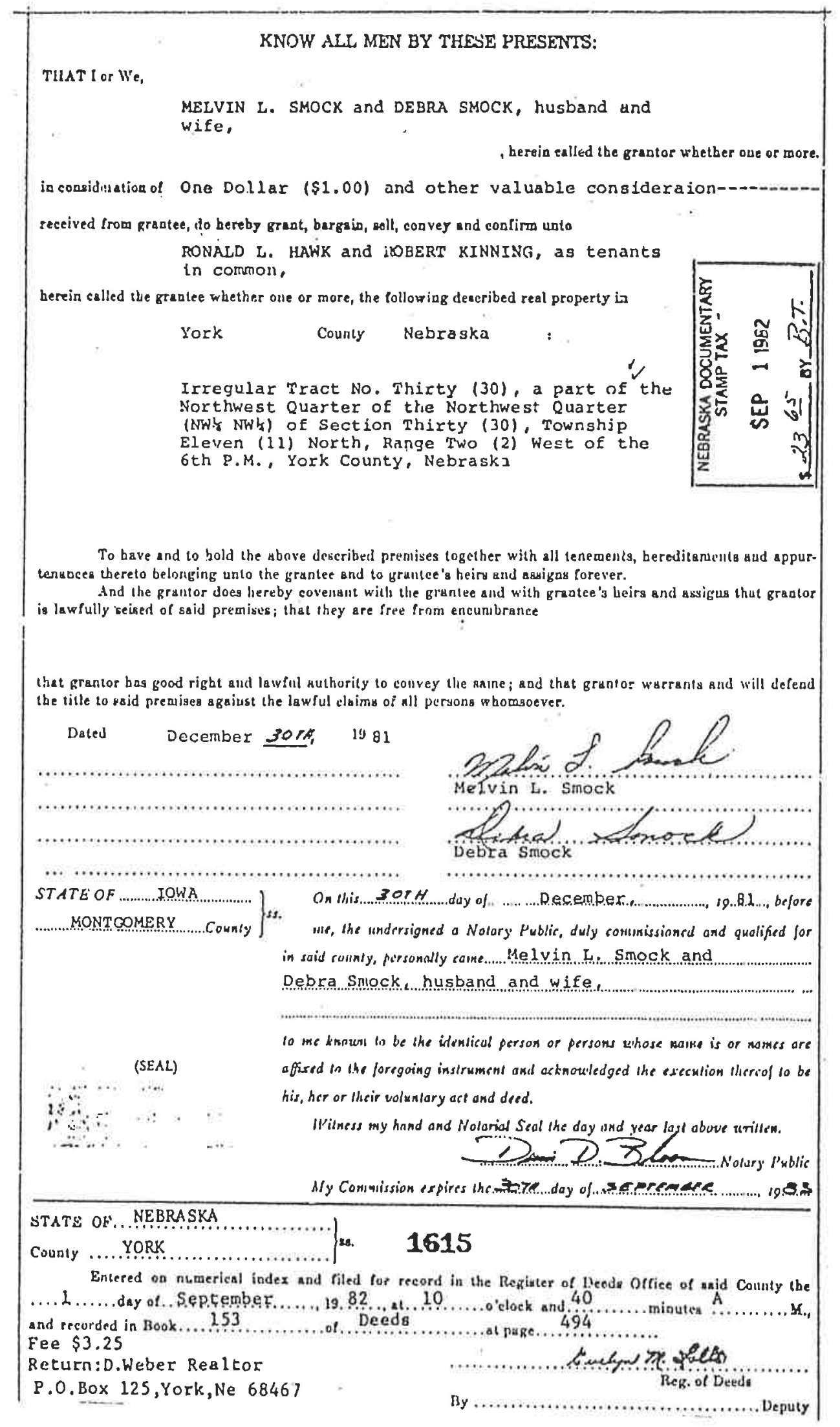




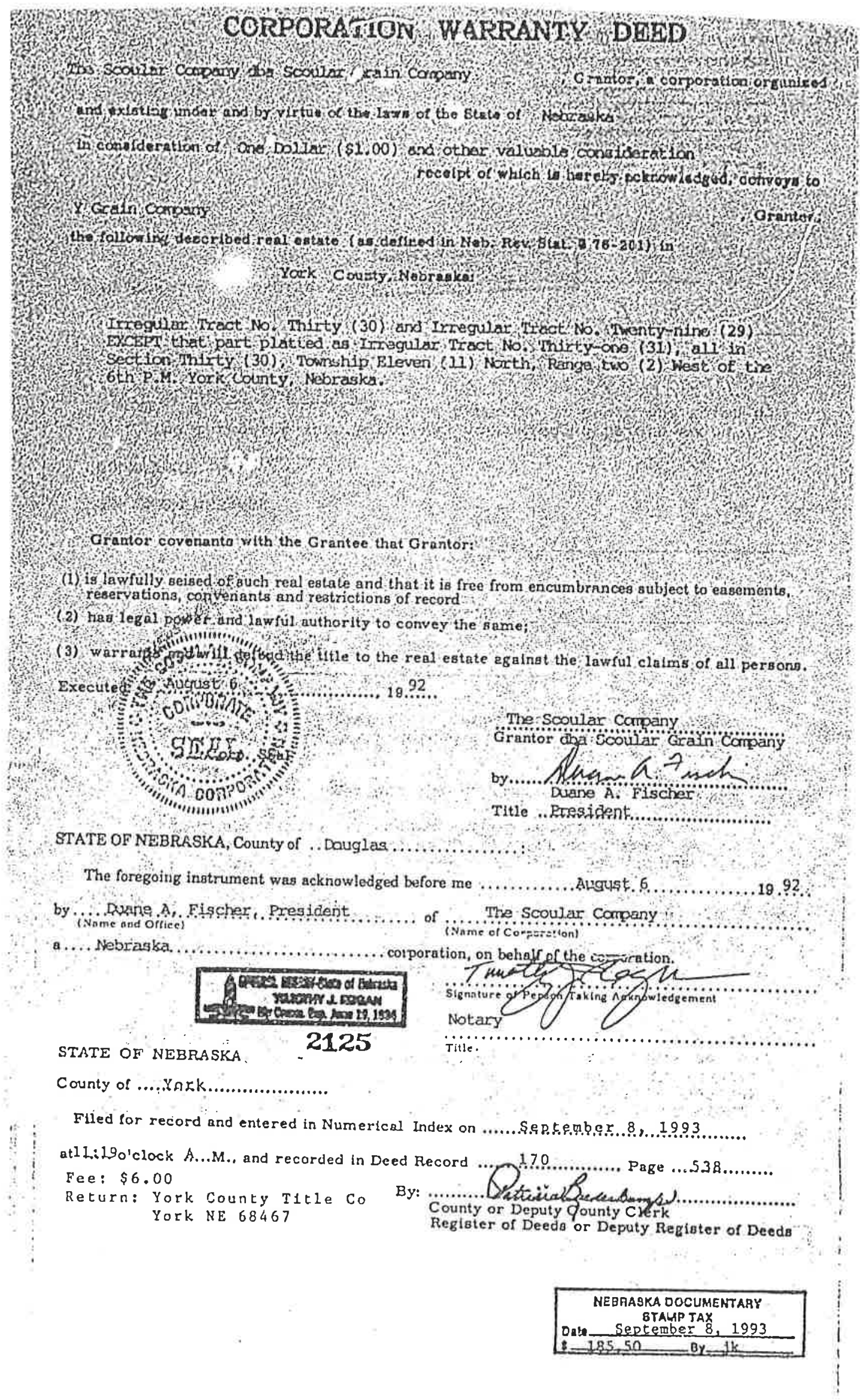




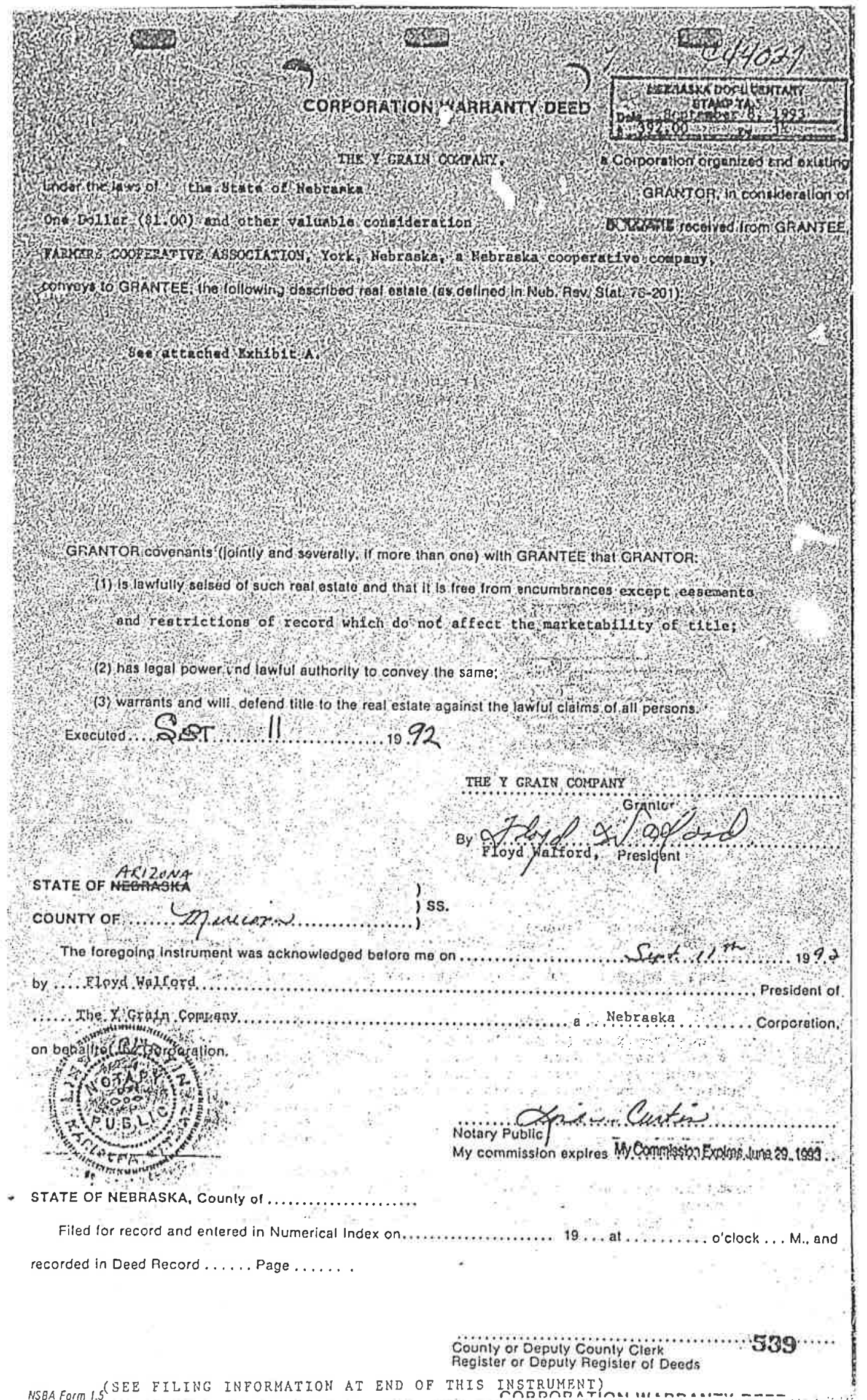




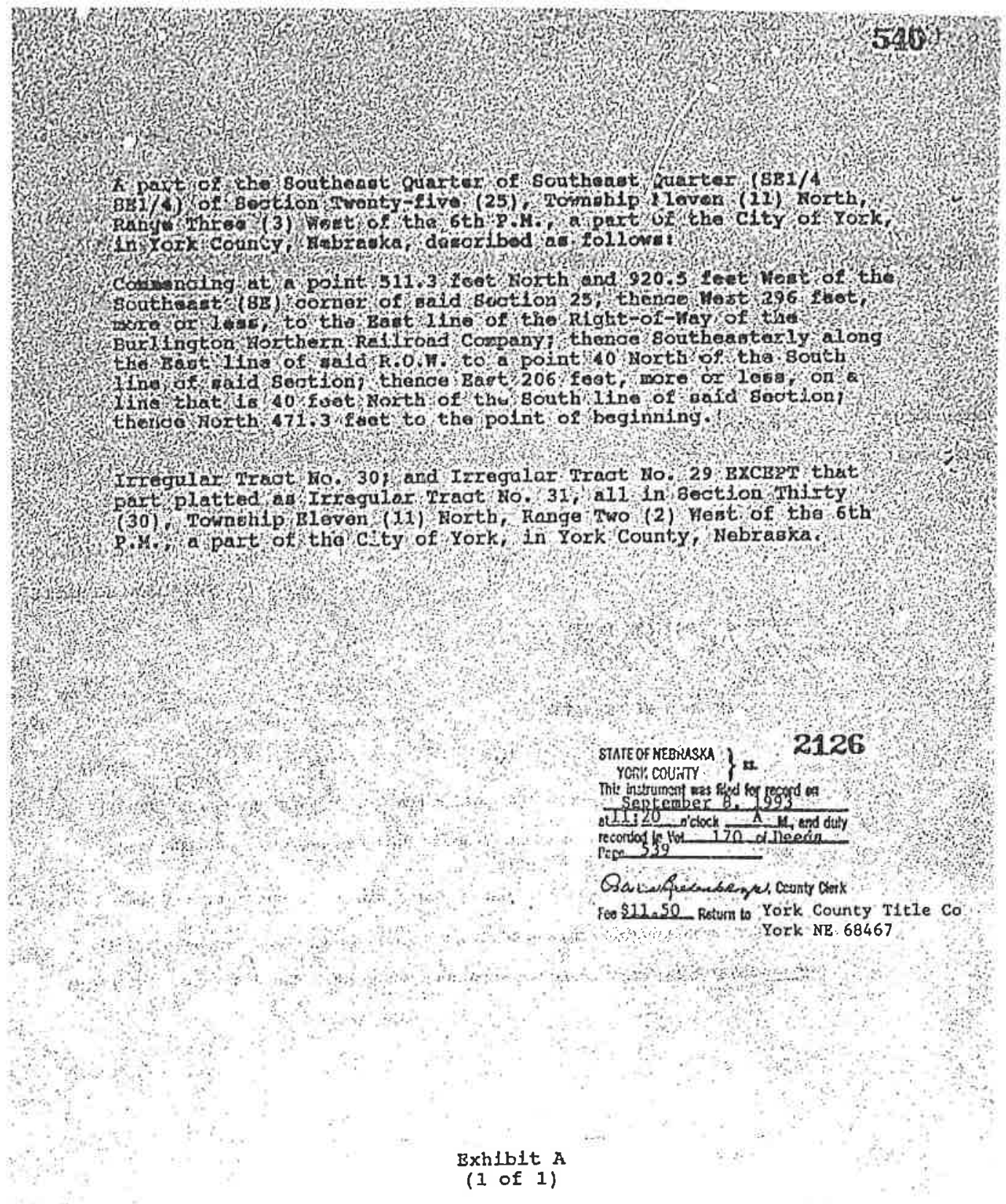




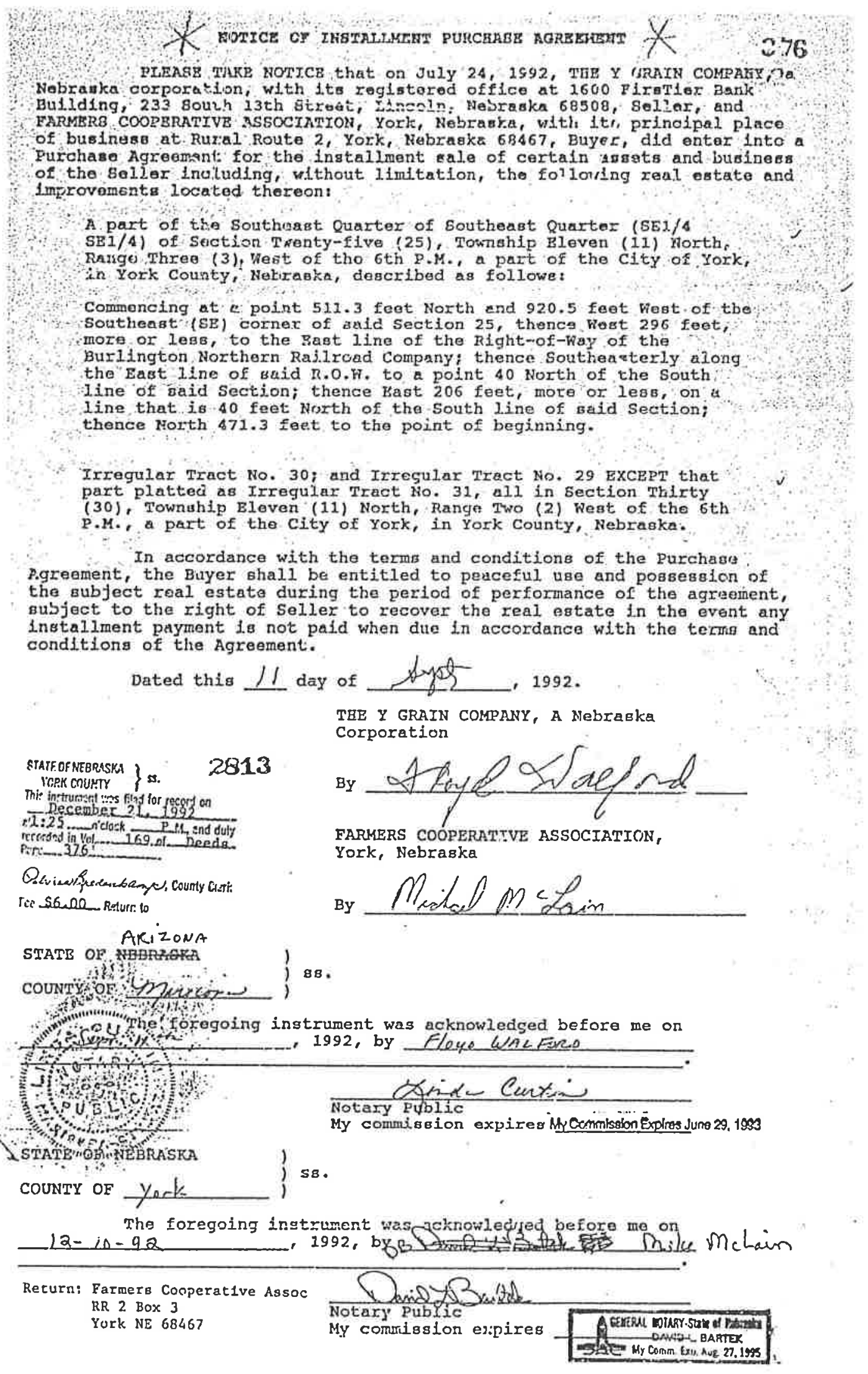




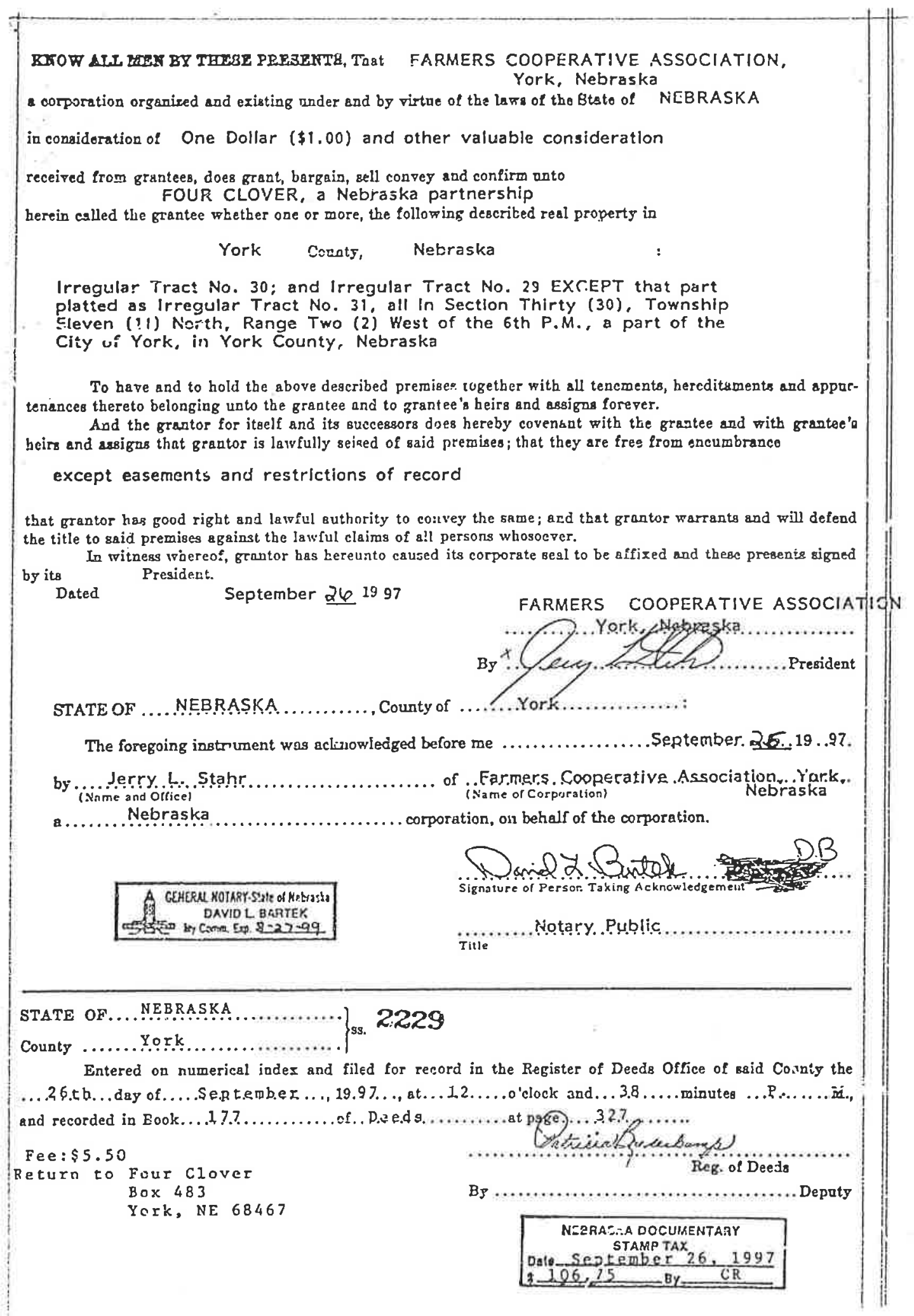


That 1, or We,

JAMES R. SHAW and AMY R. SHAW, husband and wife, and MARK R. SHAW, a single person, all of the partners in Four Clover, A Nebraska partinership,

, herein called the grantor whether one or more,

in consideration of One Dollar $(\$ 1.00)$ and other valuable consideration:

received from grantee, do hereby grant, bargain, sell, convey and confirm unto

FOUR CLOVER, L.L.C.

herein called the grantee whether one or more, the following described real property in

York County, Nebraskg :

Irregular Tract No. 30; and Irregular Tract No. 29 EXCEPT that part platted

as Irregular Tract No. 31, all in Section Thirty (30), Township Eleven (11)

North, Range Two (2) West of the 6th P.M., a part of the Cily of York, in

York County, Nebraska.

To have and to hold the above described premises together with all tenements, hereditaments and appurtenances thereto belonging unto the grantee and to grantee's heirs and assigns forever.

And the grantor does hereby coverant with the grantee and with grantee's heirs and assigns that grantor is lawfilly seised of said premises; that they are free from encumbrance.

that grantor has good right and lawful authority to convey the same; and that grantor warranis and will defend the title to said premises against the lawful claims of all persons whomsoever.

Dated: Decemher 18, 1997
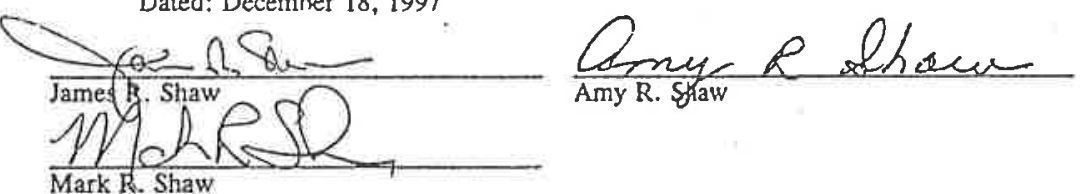

State of Nebraska )

County of York )

The foregoing instrument was acknowledged before me on December 18, 1997 ijy JAMES R. SHAW and AMY R. SHAW, husband and wife; and MARK R. SHAW, a single person.

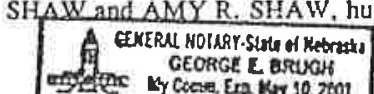

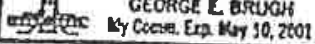

STATE OF NEBRASKA

County of York

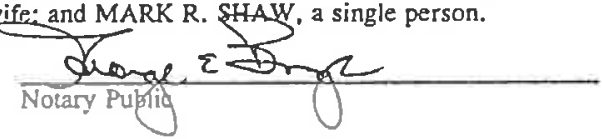

\section{7}

Entered in numerical index and filed for record in the Register of Deeds Office of said County the 18 day of December , 1997 , at 4 o'clock and 55 minutes P. M., and recorded in Book 177 of Deeds.'. ree: $\$ 5.50$

Return: George Brugh, Atty 507 L1ncolr. Ave York NE 68467

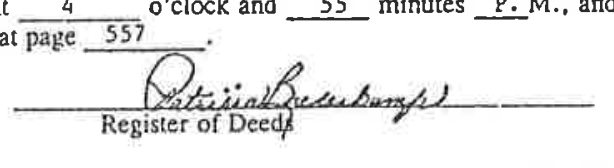

By: Deputy 
Argonne

Environmental Science Division

Argonne National Laboratory

9700 South Cass Avenue, BIdg. 203

Argonne, IL 60439-4843

www.anl.gov 